UNIVERSIDADE DE SÃO PAULO

INSTITUTO DE GEOCIÊNCIAS

\title{
QUIMIOESTRATIGRAFIA DAS ROCHAS EDIACARIANAS DO EXTREMO NORTE DA FAIXA PARAGUAI, MATO GROSSO
}

\author{
Milene Freitas Figueiredo
}

Orientadora: Profa. Dra ${ }^{a}$. Marly Babinski

DISSERTAÇÃO DE MESTRADO

Programa de Pós-Graduação em Geoquímica e Geotectônica

SÃO PAULO

2006 
"Quando eu era ainda jovem, antes de ter viajado, busquei abertamente a sabedoria. Pedi-a a Deus e busca-la-ei até o fim de minha vida. Ela floresceu como uma videira precoce e meu coração alegrou-se nela."

(Eclesiástico 51, 18-20a) 


\section{AGRADECIMENTOS}

Cresci entre pessoas simples, mas de grande sabedoria, típico das que vivem na fazenda ou cidade do interior e lembro-me de ter ouvido muito o jargão "ninguém vive sozinho", nas costumeiras rodas de prosa dos adultos. Creio que posso fazer um plágio deste dito com a frase "ninguém faz uma dissertação sozinho". Não farei uso de falsa humildade nem de demagogia, mas tão somente me esforçarei em lembrar de todos aqueles que contribuíram com o presente trabalho, direta ou indiretamente.

Como o primeiro da lista, não poderia deixar de colocar aquele que foi em todos os momentos meu grande amigo e mestre, a quem muitos chamam Deus. Em seguida aos que foram sempre meu motivo de seguir em frente, papai e mamãe (Roberto e Elizena), meus modelos de bravura e coragem. Não poderia deixar de lado os irmãos (Rafael, Gabriel e Daniela), pessoas com as quais treinei bastante a sobrevivência no "mundo lá fora", e duas pequenas alegrias recém-chegadas, os sobrinhos Matheus e João Vitor.

Acredito que os dois anos de pesquisa resultaram em conhecimentos novos e interessantes descobertas, o que certamente é devido a uma brilhante orientação. E isso eu devo primeiro a minha orientadora Marly Babinski, sempre competente, pontual, dinâmica e bastante crítica. Também fui lisonjeada com a opinião, discussão e talvez co-orientação de muitos pesquisadores sérios. Refiro-me às importantes sugestões de campo do professor Carlos Alvarenga, uma das pessoas que mais agradáveis de se trabalhar junto que conheço que, além de tudo pagou sua própria passagem para o campo. Também ao professor Francisco Pinho, mais que colega, um amigo, que foi braço direito na preparação da infra-estrutura de campo, conseguindo emprestar uma caminhonete do DNPM, combustível da METAMAT e diárias do motorista de seu próprio projeto. Outro professor, que ampliou muito meus conhecimentos sobre os carbonatos pré-cambrianos foi Paulo Boggiani, através das discussões, artigos indicados, correção de partes da redação sedimentar e patrocinador da minha participação da excursão de campo do IGCP-478 de 2004, que possibilitou grande experiência e a confirmação da origem glacial da Formação Serra Azul por mais de 15 geopesquisadores especialistas no precambriano, além de algumas reportagens na Rede Globo. Também o professor Thomas Fairchild foi fonte de aprimoramento de meu pouco conhecimento sobre a vida em tempos remotos do planeta, além de ser um exemplo de prudência nas afirmações geológicas. Ao professor Setembrino Petri, mais que agradecimento, admiração pelo amor pela pesquisa e pela universidade, demonstrado através de sua constante disponibilidade para discussões e atividade científica. Aos professores Oswaldo, Maria Helena e Colombo, obriga pelo acréscimo nos conhecimentos geocronológicos. Embora não tenha utilizado muito a geologia estrutural na dissertação, ela foi fundamental no campo, onde as seqüências estão dobradas, e o aprofundamento nesta matéria devo aos professores Ginaldo e Marcos Egídio, pessoas maravilhosas por sua simplicidade e abertura ao diálogo. Da mesma forma não utilizei microssonda de raio-x neste trabalho, a não ser para tirar dúvidas de 
uma única lâmina, mas foi uma honra conhecer esta metodologia por meio do professor Excelso. Se erros escaparam e se encontram nesta dissertação, certamente são por descuido ou teimosia minha.

Para desenvolver esta pesquisa, incomodei o pessoal de sete laboratórios do IGc/USP, mas em todos eles fui muito bem recebida. A começar pelo Laboratório de Laminação, que tão rapidamente prepararam as muitas lâminas que solicitei. O pessoal do Laboratório de Química foi formidável na acolhida e em tudo solícitos, Ricardo, Maria Inês, Margareth e Sandra, muito obrigada. A estes se soma Paulo Mori, do Laboratório de Fluorescência de raio-x, um mix de pessoa competente que gosta das coisas simples da vida, obrigada Paulinho. Igualmente a estes, estão Luis e Kelly, do Laboratório de Isótopos Estáveis, que literalmente me abriram as portas e me ensinaram o procedimento completo, gostei demais de ficar umas semanas com vocês. $\mathrm{O}$ pessoal dos laboratórios de Sr-Sr (Solange), Sm-Nd (Liliane) e K-Ar (Arthur), mais as irmãs Sonoki (Helen e Ivone) foram sempre muito competentes e disponíveis em tudo o que se referia à análise de minhas amostras, cheguei a ter aula de procedimento analítico com alguns deles, obrigada.

Não poderia deixar de lembrar todos os amigos que tornaram este período longe da família mais agradável, em especial a Cyntia Simon, meu braço direito nos trabalhos de laboratório e que agora também trabalhará na mesma região que eu. Cyntia, se não fosse você, muito estaria pela metade, obrigada. Ao pessoal do GPP (Grupo de Partilha de Profissionais) e do Grupo Ética e Transparência, muito obrigada pelo enriquecimento intelectual, companhia e baladas. Maria, Marcelo, Rafael e Luciana, amigos três-lagoenses que seguram a barra da amiga aqui. Márcia e Sérgio (Bebeto), pelo cuzcuz nordestino. Hélcio, pelo incentivo a pedir bolsa FAPESP. Ivanete, Denise e Daniele pela fundamental acolhida logo que cheguei a São Paulo. Frederico, William (Ricota) e Ramiro, companheiros de sala que muito me ensinaram. Simone e Veridiana, filhas da mesma orientadora e pessoas extremamente sensatas. Alejandro, Marta e Ariana (a geofamília), Augustin, Lígia, Sérgio (cara divertido), Juli, Rogério, Gaston, Paula (Pi), Kleber, Sílvia e Aline, obrigada pelos bons momentos de festas, risadas no horário de almoço, discussões acadêmicas, etc.

Agradeço a bolsa CNPq, que desfrutei por seis meses, e pela bolsa e reserva técnica da FAPESP, processo n. 04/06225-5, usufruída nos últimos 1,5 ano. Ao apoio de campo dado pela Empresa COPACEL e pela Fazenda Serra Azul, assim como a permissão de entrada na reserva ambiental da Indústria Cimento Itaú, onde se fez importante descoberta geológica. 
INDICE

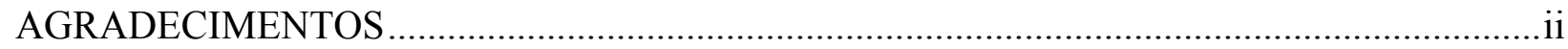

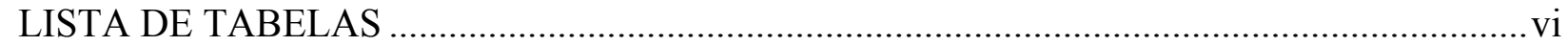

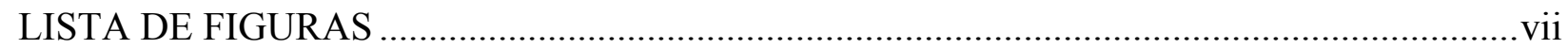

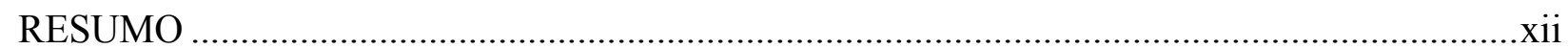

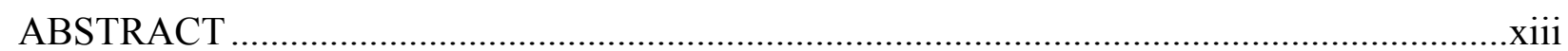

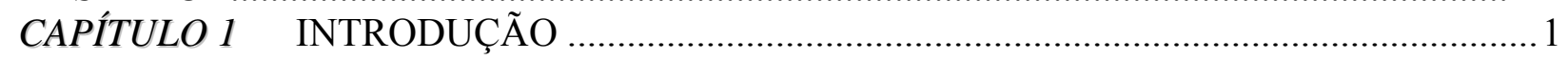

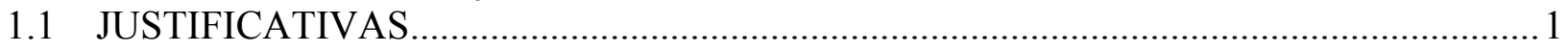

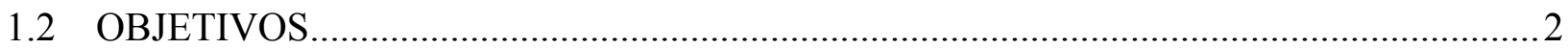

CAPÍTULO 2 FUNDAMENTAÇÃO TEÓRICA …............................................................ 3

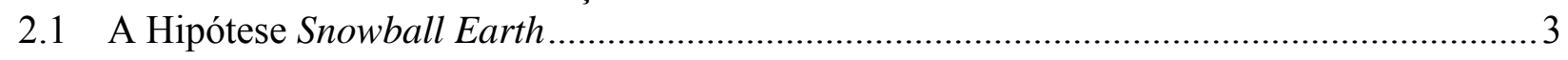

2.1.1 Construção da Hipótese Snowball Earth...................................................................... 4

2.1.2 Resumo da Hipótese Snowball Earth............................................................................. 5

2.1.3 Outras Hipóteses em Contraste ............................................................................ 9

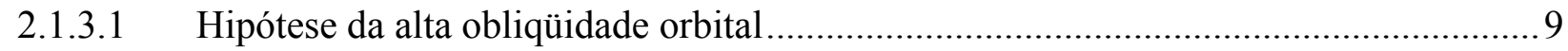

2.1.3.2 Hipótese dos anéis de gelo em órbita da Terra.................................................... 10

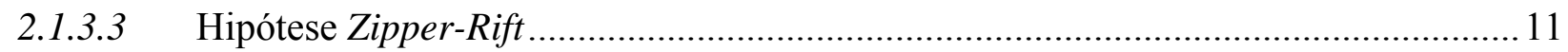

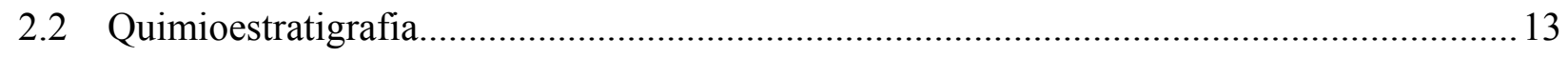

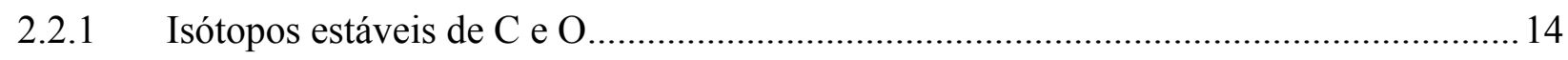

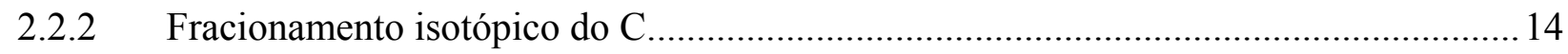

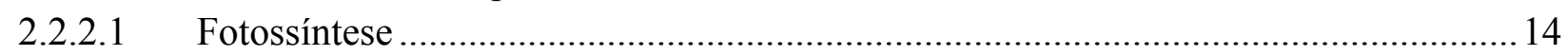

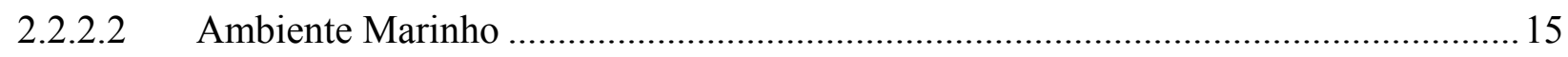

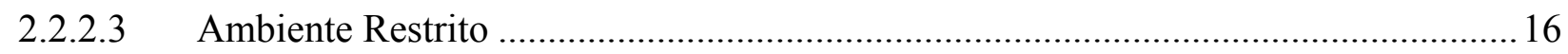

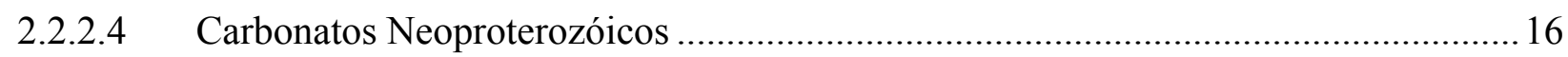

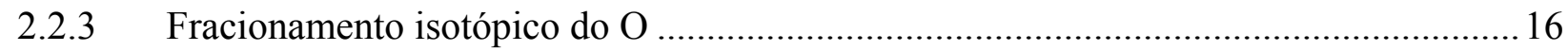

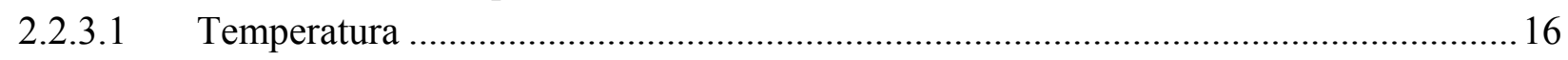

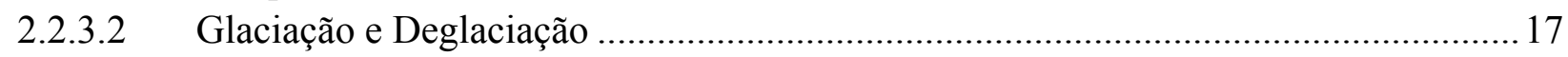

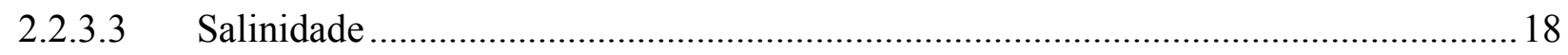

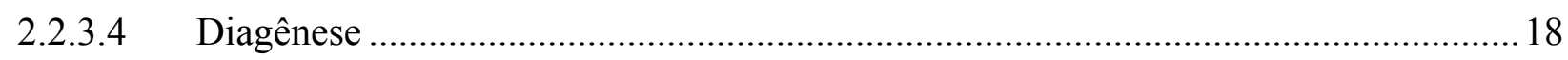

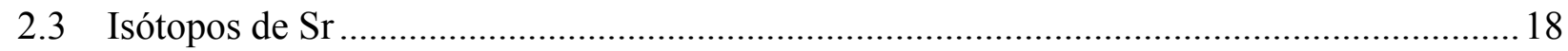

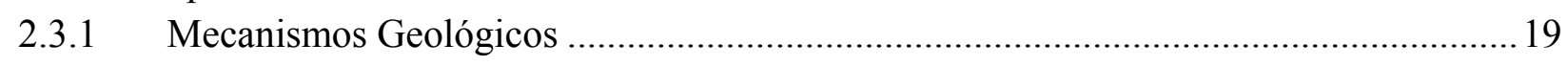

2.3.1.1 Atividade hidrotermal das cadeias meso-oceânicas ................................................ 19

2.3.1.2 Processos orogênicos e configurações paleogeográficas .......................................... 19

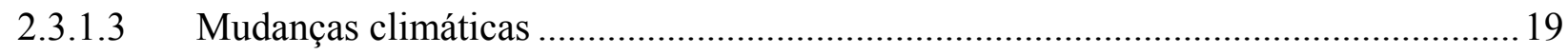

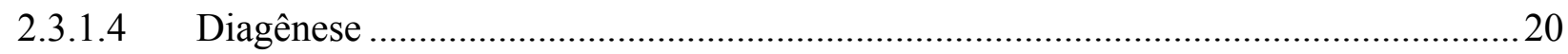

2.3.1.5 Mudanças no nível do mar ...................................................................................... 20

2.3.1.6 Comutação entre os modos de circulação oceânica .................................................. 20

2.3.1.7 Eventos geológicos instantâneos ......................................................................20

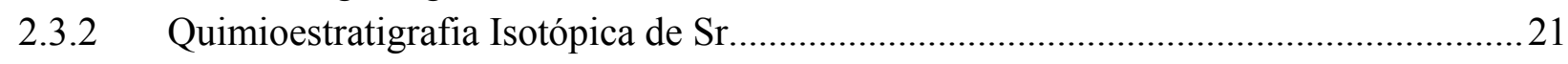

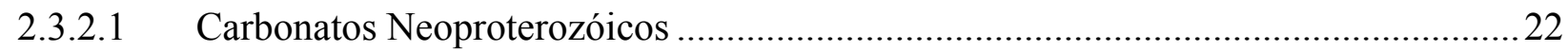

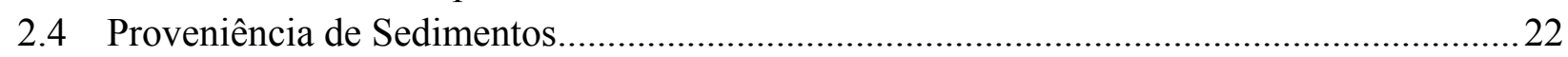

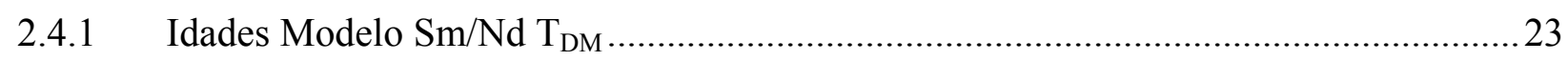

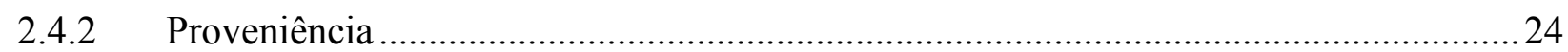

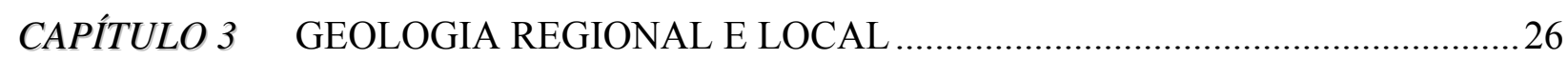




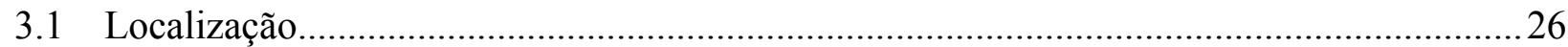

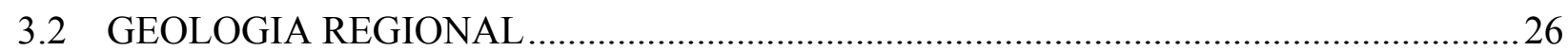

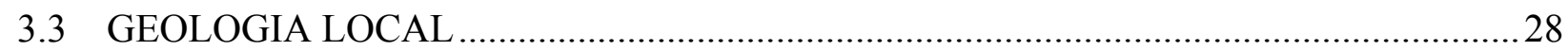

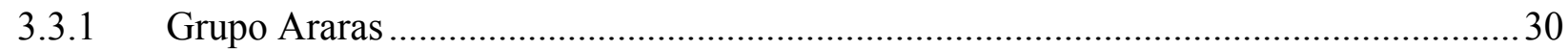

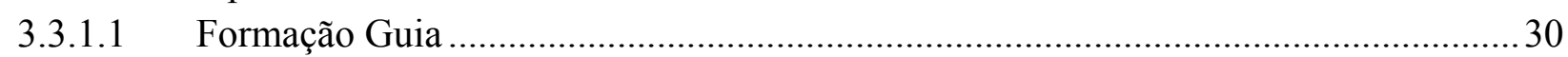

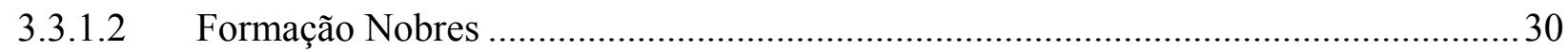

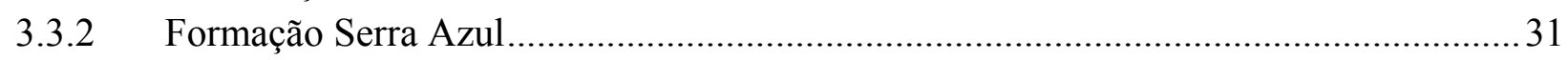

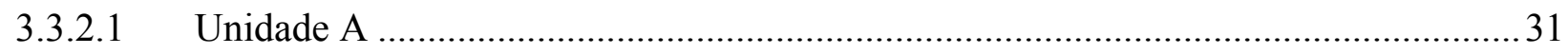

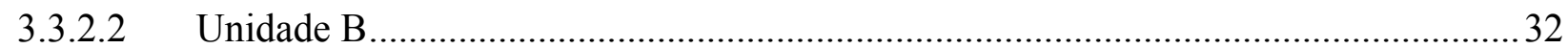

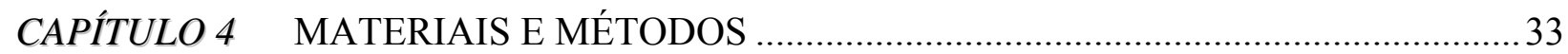

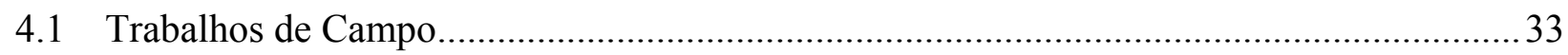

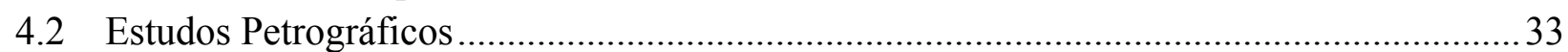

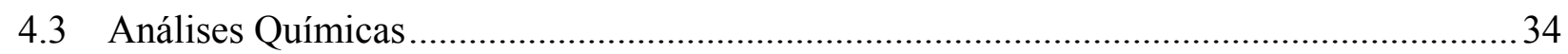

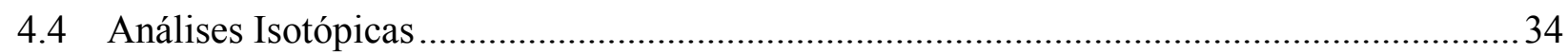

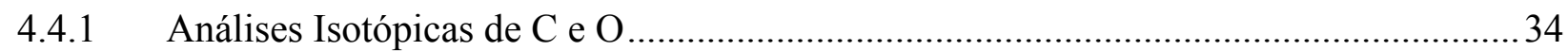

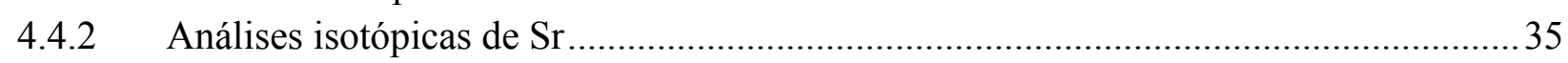

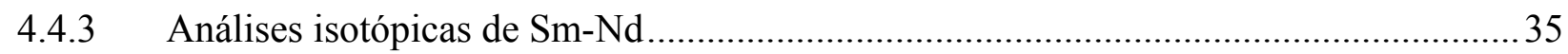

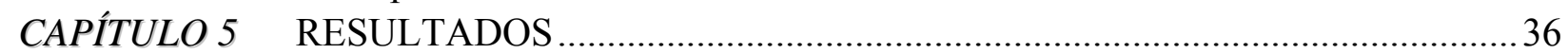

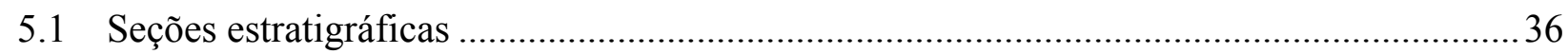

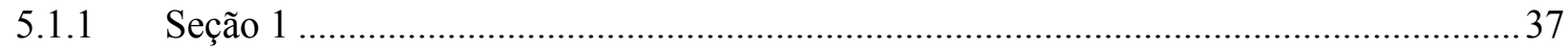

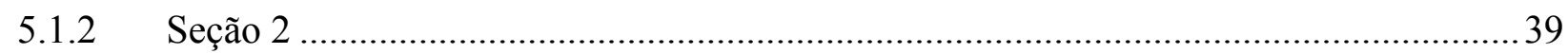

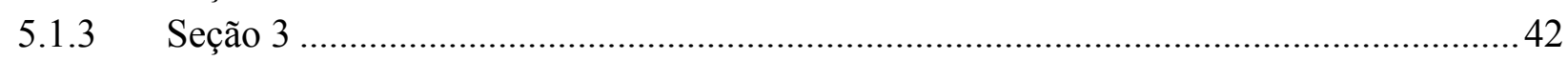

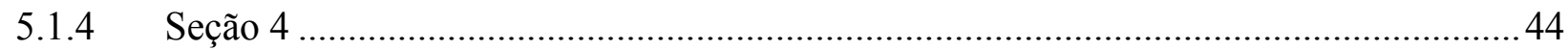

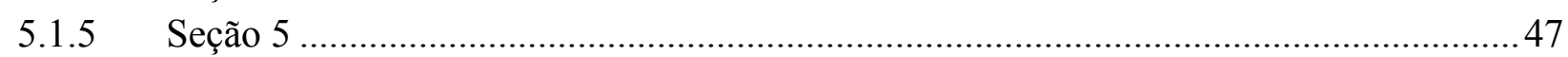

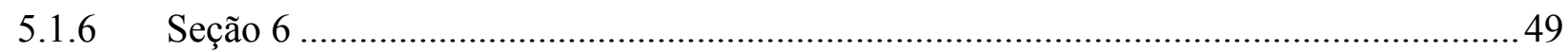

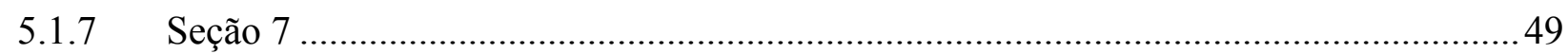

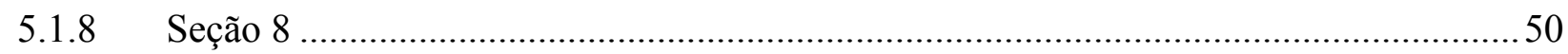

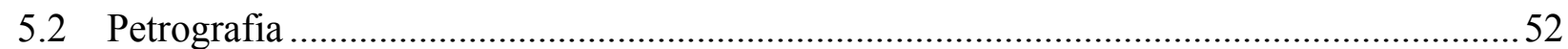

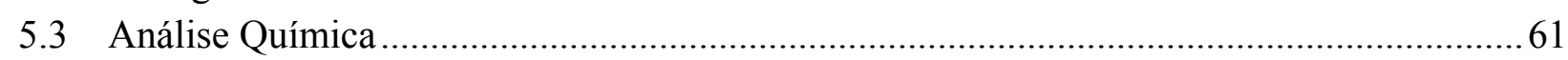

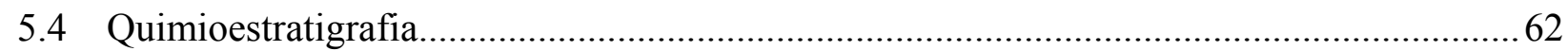

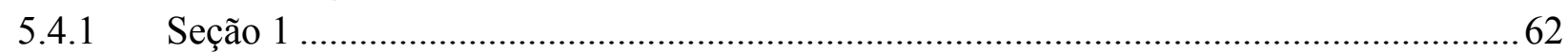

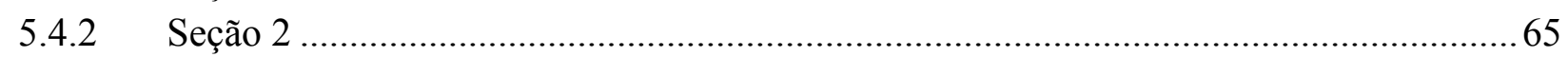

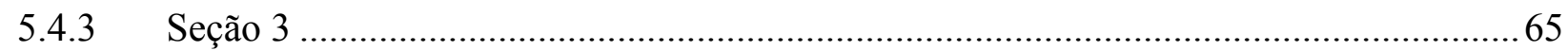

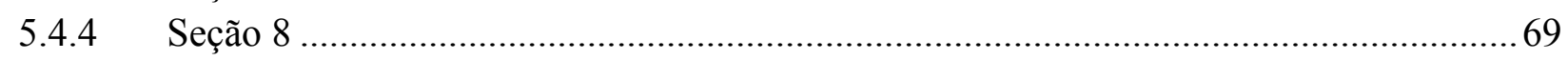

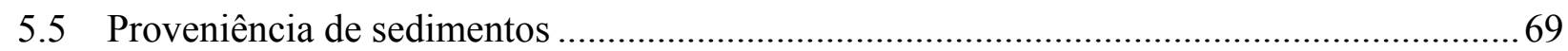

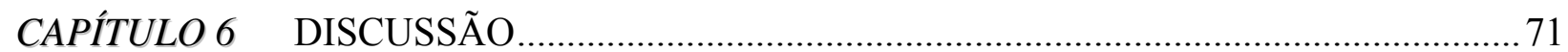

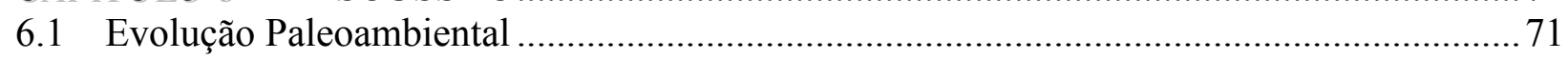

6.2 Diagênese e Processos Pós-Deposicionais ......................................................................... 76

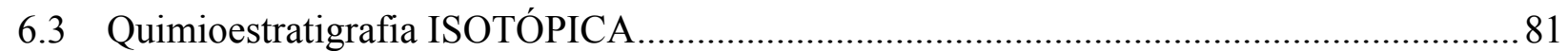

6.3.1 Correlação com outras seqüências da Faixa Paraguai................................................... 85

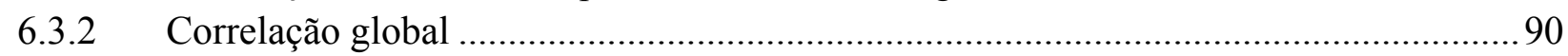

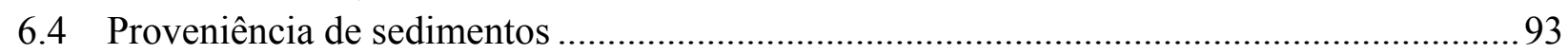

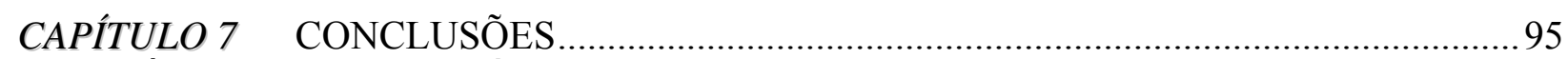

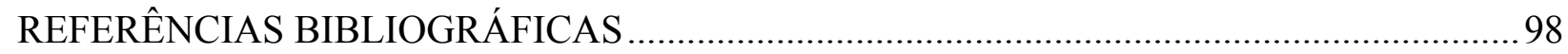




\section{LISTA DE TABELAS}

Tabela 1. Características Glaciais Proterozóicas e as Hipóteses que as explicam, modificado de Kirschivink (2002).

Tabela 2. Reações em cadeia do intemperismo de carbonatos e silicatos, transporte dos cátions dissolvidos e deposição de novos minerais. Importante notar que, em ambos os casos, são depositados novos carbonatos.

Tabela 3. Classificação das rochas carbonáticas segundo Dunham (1962). 36

Tabela 4. Descrição petrográfica sucinta, com a classificação das amostras de rochas carbonáticas e sua possível interpretação......................................................................54

Tabela 5. Resultados das análises químicas obtidos nos carbonatos do Grupo Araras e da Formação Serra Azul. As seções estratigráficas correspondentes estão indicadas à esquerda (S1, S2, S3 e S8). Os campos marcados com * indicam resultados em fase de obtenção.... 63

Tabela 6. Resultados das análises isotópicas nos carbonatos do Grupo Araras e da Formação

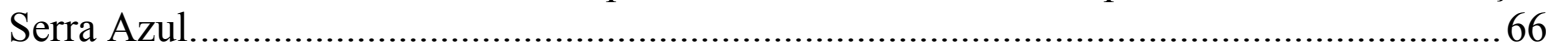

Tabela 7. Resultados da análise Sm/Nd obtidos para os pelitos da Formação Serra Azul. 69 


\section{LISTA DE FIGURAS}

Figura 1. Os quatro estágios da hipótese Snowball Earth, apresentando as variações no albedo planetário, dióxido de carbono atmosférico, temperatura superficial, profundidade troposférica, precipitação, extensão glacial e profundidade do gelo marinho (modificado de Hoffman \& Schrag, 1999).

Figura 2. Gráfico baseado num modelo simples de balanço de energia do tipo Budyko-Sellers (modificado de Hoffman e Schrag, 2002), mostrando a latitude da linha de gelo (ao nível do mar) como uma função do fluxo solar efetivo (Es), ou equivalente para $\boldsymbol{p} \mathrm{CO}_{2}$ (para Es $1 / 4$ 1,0). O efeito de uma redução de $30 \%$ no transporte meridional mais quente é apresentado (linha cinza), como o fluxo solar estimado há ca. $600 \mathrm{Ma}$. Iniciando do ponto 1, a redução de $\boldsymbol{p} \mathrm{CO}_{2}$ provoca a migração constante das linhas de gelo para o ponto 2 (linha cheia), onde a realimentação descontrolada do albedo leva as linhas de gelo à área coberta de gelo no ponto 3. A emanação normal de gases vulcânicos por milhões de anos aumenta a $\boldsymbol{p C O}_{2}$ para o ponto 4 , iniciando a deglaciação. A realimentação inversa do albedo do gelo, leva rapidamente as linhas de gelo à área sem gelo, no ponto 5, onde a alta $\mathrm{pCO}_{2}$ e o baixo albedo planetário produz uma ultra-estufa transitória. $\mathrm{O}$ intemperismo silicático intensificado provoca a redução de $\mathrm{pCO}_{2}$ ao ponto 6 , conseqüentemente as capas de gelo polar se refazem e as linhas de gelo voltam à área parcialmente coberta de gelo, no ponto 7 .

Figura 3. Gráfico das ocorrências de formações ferríferas sedimentares através do tempo geológico, à esquerda, e mecanismo de deposição do ferro numa situação de Snowball Earth, diagrama à direita (modificado de Hoffman e Schrag, 1999). Se o oxigênio $\left(\mathrm{O}_{2}\right)$ é ausente, o ferro é solúvel como íon ferro-ferroso $\left(\mathrm{Fe}^{2+}\right)$, enquanto que na presença de $\mathrm{O}_{2} \mathrm{O}$ ferro é insolúvel como íon ferro-férrico $\left(\mathrm{Fe}^{3+}\right)$.

Figura 4. Para uma obliqüidade maior que $54^{\circ}$, as temperaturas seriam mais baixas nos trópicos que nos pólos, sendo a glaciação de baixa latitude causada unicamente pela sazonalidade extrema (modificado de Hoffman \& Schrag, 1999). 10

Figura 5. Imagens dos anéis de Saturno feitas pela sonda Cassini. À esquerda podem-se observar os quatro anéis mais internos (dos sete que possui), com detalhe da composição granulométrica, adquirida por espectrômetro de mapeamento infravermelho. As partículas dos anéis de saturno são compostas essencialmente por gelo de água (conforme detalhe do anel $\mathrm{A}$, à direita) e variam em tamanho de mícrons a dezenas de metros. Os principais anéis (A, B e C) são relativamente jovens e possuem poucas centenas de milhões de anos e devem ter se formado pela quebra de um satélite, ou de um cometa ou meteoro capturado pela gravidade de saturno (modificado de Nasa, 2004; Doherty \& Wegryn, 2004).

Figura 6. Eras tidas como glaciais e variação isotópica do carbono no contexto dos ciclos tectônicos globais. De acordo com Eyles \& Januszczak (2004), o rifteamento de supercontinentes parece estar associado às notáveis excursões isotópicas, refletindo tão somente o aumento do soterramento do carbono orgânico em bacias tipo rift recém formadas e com alta taxa de subsidência (modificado de Eyles \& Januszczak, 2004)......... 12

Figura 7. Nos quadros A e B está representado o rifteamento como um evento sincrônico, porém a quebra dos blocos continentais seria na forma de um 'zipper'. Em A, a primeira fase do rifteamento do Rodinia após $750 \mathrm{Ma}$, com a abertura do oceano Paleo-Pacífico. Em B, a segunda fase do rifteamento do Rodinia por volta de $650 \mathrm{Ma}$, com a abertura do oceano Iapetus (modificado de Eyles \& Januszczak, 2004)..... 
Figura 8. Ciclo do Carbono na Terra. O carbono fornecido à atmosfera e aos oceanos é proveniente das emanações vulcânicas na forma de dióxido de carbono, contendo cerca de $1 \%$ de ${ }^{13} \mathrm{C}$ e $99 \%$ de ${ }^{12} \mathrm{C}$. Se a remoção do carbono dos oceanos ocorresse apenas pelo soterramento de carbonato, esta razão isotópica seria mantida. Porém, o carbono também é removido na forma de matéria orgânica, tecido mole de algas e bactérias viventes na água do mar, que fracionam esta razão isotópica, sendo empobrecida cerca de $2,5 \%$ em ${ }^{13} \mathrm{C}$ (Hoffman \& Schrag, 1999)......

Figura 9. Curva de variação global de $\delta^{13} \mathrm{C}$ através do tempo, proposta por Halverson et al. (2005) para o Neoproterozóico, com as idades obtidas recentemente por diversos pesquisadores marcadas acima em Ma.

Figura 10. Curva temporal de ${ }^{87} \mathrm{Sr} /{ }^{86} \mathrm{Sr}$ para os carbonatos neoproterozóicos com as medições realizadas por diversos pesquisadores em várias formações geológicas, mostrando divergência entre 900 e $590 \mathrm{Ma}$ (Melezhik et al., 2001).

Figura 11. Representação de duas idades $\mathrm{T}_{\mathrm{DM}}$, onde as linhas pretas representam a evolução do manto não empobrecido (linha CHUR) e do manto empobrecido (curva DM) e as linhas coloridas a evolução isotópica de $\varepsilon_{\mathrm{Nd}}$ das rochas através do tempo.

Figura 12. Bloco diagrama mostrando relação entre as idades $\mathrm{T}_{\mathrm{DM}}$ dos sedimentos, depositados numa bacia sedimentar qualquer, e de sua área-fonte (modificado de Kulerud, 2005)....... 25

Figura 13. Mapa de localização indicando as áreas de estudo e vias de acesso (modificado do Mapa Político, Rodoviário e Estatístico de Mato Grosso, edição 2000).

Figura 14. Mapa geológico regional da Faixa Paraguai em Mato Grosso (modificado de Alvarenga, 1988), com as áreas selecionadas para estudo e as seções detalhadas.

Figura 15. Coluna estratigráfica esquemática da Faixa Paraguai no Estado de Mato Grosso (modificado de Alvarenga, 1988).

Figura 16. Coluna estratigráfica da Formação Serra Azul, compartimentada informalmente em duas unidades litológicas: diamictitos de origem glacial (Unidade A) e laminitos gerados pelo degelo (Unidade B), com deposição de carbonato e terrígenos no topo.

Figura 17. Mapa geológico de localização das 8 seções estudadas.

Figura 18. Colunas estratigráficas das 8 seções estudadas. 38

Figura 19. Fotos da Seção 1, Formação Guia: (A) diamictito da Formação Puga com clasto granítico, (B) laminação ondulada e truncada, (C) chert preservando calcário no interior, (D) mudstone laminado, (E) mudstone maciço, (F) mudstone preto laminado e (G) laminação irregular possivelmente biogênica.

Figura 20. Foto (A) panorâmica da Pedreira Copacel II (Seção 2, Formação Guia), estando o topo para a esquerda, com fotos de detalhe com visada no mesmo sentido. Existe intercalação persistente de mudstone finamente laminado rico em matéria orgânica $(\mathrm{O})$, mudstone rítmico contendo algumas lentes de wackestone intraclástico $(\mathrm{R})$, e lente de mudstone maciço $(\mathrm{M})$ que ocorre sempre em contato com os ritmitos. Em (B) um detalhe dos ritmitos alternando pares claro-escuro; em (C) contato de topo ondulado entre o mudstone maciço e o ritmito e (D) passagem do ritmito laminado (direita) para o mudstone finamente laminado rico em matéria orgânica (esquerda).

Figura 21. Fotos dos calcários da Seção 2: (A) mudstone laminado com nódulos alongados de chert preto, em acamamento vertical; (B) detalhe de (A); (C) packestone originado por brechação de mudstone rítimico sobreposto por mudstone rítmico fraturado, notar contato 
plano-erosivo; (D) laminação rítmica com camada dobrada por escorregamento; (E) contato entre mudstone preto e mudstone claro com laminação irregular deformado por estilólito; (F) wackestone de clastos de calcário preto imerso em calcário claro; (G) mudstone e wackestone em finas camadas truncadas sobreposto por packestone de intraclastos claros e matriz escura, em contato deformado; $(\mathrm{H})$ wackestone de intraclastos escuros imersos em matriz clara; (I) mudstone em finas camadas contendo nódulos de silicificação pontual, comumente resistentes aos estilólitos.

Figura 22. Fotos da Seção 3, na sua porção basal-mediana: (A) ritmito dolomitizado; (B) porosidade causada pela dolomitização; (C) dolomitização intensa, sem evidências de estruturas primárias; (D) silicificação intensa, notar estrutura arqueada para cima, possível tepee; (E) mudstone laminado rico em óxido de ferro; $(\mathrm{F})$ dolomudstone secundário apresentando fantasmas da laminação; $(\mathrm{G})$ dolomudstone com nódulos de chert. 45

Figura 23. Fotos da Seção 3, na porção mediana-superior: (A) seqüência turbidítica em dolomudstone impuro, apresentando estrutura de corte, preenchida por laminação agradacional e seguida de laminação cruzada tipo climbing e laminação granodecrescente; (B) dolomudstone com lâminas deformadas de chert branco intercaladas; (C) dolograinstone de intraclastos e oncólitos granodecrescente, com porosidade fenestral; (D) estromatólito dendróide evoluindo para esteiras algais (relação deformada por estilólitos) e novamente para colunas; (E) dolomudstone primário; $(\mathrm{F})$ dolomudstone primário granodecrescente nas porções mais escuras; (G) arenito da Formação Raizama apresentando laminação em camadas truncadas, com pelotas de argila nos planos de laminação.

Figura 24. Fotos da Formação Serra Azul na região da Serra Azul (seções 4, 5, 6 e 7): (A) diamictito maciço contendo pequeno bloco de chert; (B) diamictito maciço contendo seixo arredondado de arenito e bloco anguloso de carbonato em contato com chert; (C) diamictito maciço com pequeno bloco de carbonato laminado; (D) laminito vermelho em afloramento alterado, apresentando ondulação simétrica; (E) laminito cinza aparentemente rítmico; (F) contato brusco entre arenito e conglomerados da Formação Raizama, cimentados por óxido de ferro.

Figura 25. Fotos da Formação Serra Azul na região homônima (seções 4, 5, 6 e 7): (A) padrão de alteração intempérica dos diamictitos, como se vê na mademoiselle gigante de arenito; (B) clasto retirado do diamictito de granito em forma de ferro de engomar; (C) clasto oblato de granito fino em contato com granito médio, retirado do diamictito, mostrando sua superfície toda estriada por intensa abrasão, especialmente aquelas planas e de maior área; (D) clasto de quartzito polido, retirado do diamictito, com algumas estrias mais evidentes; (E) clasto de arenito, retirado do diamictito, com base plana estriada; (F) diamictito com laminação incipiente com clasto de carbonato em forma de ferro de engomar; $(\mathrm{G})$ laminito amarelo ferruginoso, com fina camada síltica branca persistente; $(\mathrm{H})$ laminito amarelo com camadas de material siltoso de coloração esbranquiçzada e de laminito rico em ferro e manganês...51

Figura 26. Fotos da Formação Serra Azul (Seção 8): (A) laminito vermelho; (B) mudstone laminado da base; (C) mudstone deformado por escorregamento seguido por mudstone laminado; (D) mudstone deformado por escorregamento, seguido por mudstone laminado e packestone de intraclastos; (E) mudstone mostrando deformação progressiva por compactação, como evidencia a lâmina de argila vermelha mais deformada na base e menos deformada no topo, onde as lâminas mais finas de argila e calcário encontram-se truncadas ou rompidas; (F) mudstone com lâminas deformadas por compactação evoluindo para textura nodular; $(\mathrm{G})$ mudstone maciço apresentando estilólitos; $(\mathrm{H})$ mudstone maciço apresentando estrutura de corte preenchida por wackestone com matriz impura na fração areia com alguns intraclastos. 
Figura 27. Fotomicrografia dos carbonatos estudados, nicóis cruzados: (A) exemplo de mudstone da Seção 8; (B) detalhe de outro mudstone da mesma seção; (C) packestone de ritmito brechado sotoposto a ritmito mostrado na foto (D) em contato plano erosivo, Seção 2; (E) detalhe do contato inferior entre nódulo de chert (em cinza, acima) ocorrente na base da Seção 2 e mudstone rico em matéria orgânica (abaixo), com calcita espática euédrica crescendo da borda para o centro do chert; $(\mathrm{F})$ detalhe do contato lateral entre mesmo nódulo de chert (em cinza a esquerda) e mudstone (direita), o contato é irregular e marcado pela presença de calcita espática anédrica passando a calcita fibrosa.

Figura 28. Fotomicrografia dos carbonatos estudados, nicóis cruzados: (A) mudstone da Seção 1; (B) textura peloidal rica em matéria orgânica, apresentando grande quantidade de pirita e pequenas esferas que lembram pequenas algas e esfera com morfologia trilateral, possível microfóssil, Seção 2; (C) textura grumosa nas lâminas mais claras da mesma amostra; (D) ondulações simétricas, Seção 2; (E) pirita envolvida por aglomerados que lembram colônia de bactérias redutoras, predominantemente associada aos níveis ricos em matéria orgânica; (F) detalhe de possível colônia de bactérias redutoras na mesma amostra, com luz condensada.

Figura 29. Fotomicrografia dos carbonatos estudados, nicóis cruzados: (A) silicificação pontual de mudstone em micronódulos radiais, Seção 2; (B) laminação rica em matéria orgânica arqueada, Seção 3; (C) exemplo de dolomito cristalino, mostrando cristais grandes de dolomita anédrica, Seção 3; (D) grainstone de intraclastos e pellets micritizados, cimentados por calcita espática, Seção 3; (E) detalhe de porosidade secundária; (F) intraclastos preenchendo estrutura de corte na base de uma seqüência turbidítica, Seção 3.59

Figura 30. Fotomicrografia dos carbonatos estudados, nicóis cruzados: (A) dolomudstone maciço, Seção 3; (B) textura peloidal com estreita lâmina possivelmente biogênica, Seção 3; (C) dolomudstone, intercalado a dolograinstone de intraclastos e oncólitos micritizados, cimentados por calcita espática, mostrado na foto (D); (E) dolograinstone com detalhe de fraturamento de intraclasto alongado durante compactação, Seção3; (F) detalhe de porosidade fenestral de $(\mathrm{E})$.

Figura 31. Quimioestratigrafia das seções 1 (A), 2 (B), 3 (C) e 8 (D), empilhadas estratigraficamente, de baixo para cima e da esquerda para a direita, para melhor visualização. As razões ${ }^{87} \mathrm{Sr} /{ }^{86} \mathrm{Sr}$ estão notadas em verde, nas respectivas posições estratigráficas.

Figura 32. Gráficos de dispersão entre a razão $\mathrm{Mn} / \mathrm{Sr}$ e os valores de $\delta^{13} \mathrm{C}, \delta^{18} \mathrm{O}$ e ${ }^{87} \mathrm{Sr} /{ }^{86} \mathrm{Sr}$. Todas as amostras possuem razões $\mathrm{Mn} / \mathrm{Sr}$ inferiores a 2, sendo inferiores a 0,25 para as amostras analisadas para ${ }^{87} \mathrm{Sr} /{ }^{86} \mathrm{Sr}$, o que garante empiricamente a qualidade dos resultados isotópicos. As amostras correspondentes da Formação Nobres são as que possuem as razões $\mathrm{Mn} / \mathrm{Sr}$ mais altas e se mostram isotopicamente mais pesadas. A correlação entre os valores não segue um padrão bem definido nos gráficos $\delta^{13} \mathrm{C}$ vs. $\mathrm{Mn} / \mathrm{Sr}, \mathrm{e}^{87} \mathrm{Sr} /{ }^{86} \mathrm{Sr}$ vs. $\mathrm{Mn} / \mathrm{Sr}$, mas tende a uma correlação aproximadamente positiva quando comparados $\delta^{18} \mathrm{O}$ vs. $\mathrm{Mn} / \mathrm{Sr} . .68$

Figura 33. Gráficos de dispersão da razão $\mathrm{Mg} / \mathrm{Ca}$ versus $\delta^{18} \mathrm{O}(\mathrm{A}), \delta^{13} \mathrm{C}(\mathrm{B}), \mathrm{Sr}(\mathrm{C})$ e $\mathrm{Si}(\mathrm{D})$. Nas figuras $\mathrm{A}$ e $\mathrm{B}$ não se observa correlação positiva entre $\mathrm{Mg} / \mathrm{Ca}$ e $\delta^{18} \mathrm{O}$ ou $\delta^{13} \mathrm{C}$, embora seja evidente que os dolomitos da Formação Nobres sejam isotopicamente mais pesados que os calcários das formações Guia e Serra Azul. Os termos dolomíticos também são os que apresentam a menor teor de $\mathrm{Sr}(\mathrm{C})$. Em relação ao Si (D) não há boa correlação global, no entanto as amostras da Formação Guia apresentam uma tendência de correlação positiva. 68 
Figura 34. Gráfico apresentando as idades $\mathrm{T}_{\mathrm{DM}}$ em relação ao $\varepsilon_{\mathrm{Nd}}$ das amostras analisadas. As 4 linhas em vermelho são dados da seção 4 , as 2 linhas em verde são dados da seção 5 e as 2 linhas em azul são dados da seção 8.

Figura 35. Coluna estratigráfica regional simplificada das áreas estudadas. A granulometria máxima está notada como: (a) argila, (s) silte, (Af) areia fina, (Am) areia média, (Ag) areia grossa, (g) grânulo, (b) bloco, (m) matacão.

Figura 36. Evolução sedimentar da Bacia Paraguai em Mato Grosso: (A) Glaciação Puga, com deposição da Formação Puga e maior parte do Grupo Cuiabá; (B) deglaciação Puga, com deposição de carbonatos predominantemente calcários da Formação Guia; (C) regressão marinha e aquecimento, com deposição da Formação Nobres; (D) glaciação Serra Azul, com deposição dos diamictitos da formação homônima; (E) deglaciação Serra Azul, com deposição dos laminitos e calcários da formação homônima; (F) regressão marinha com a deposição de camadas de arenito intercaladas com pelitos da Formação Serra Azul progredindo para os arenitos e conglomerados da Formação Raizama. 75

Figura 37. Dados isotópicos de $\mathrm{C}$ e $\mathrm{O}$ obtidos em carbonatos. A linha preta corresponde a ambiente de inframaré, a linha cinza de intermaré e a linha branca de supramaré. 78

Figura 38. Relação entre $\mathrm{Sr} / \mathrm{Ca}$ e $\mathrm{Mn}$ para os carbonatos estudados. A seta indica a direção de alteração durante o aumento da interação com fluidos não marinhos (água doce, meteórica ou mistura de ambas, ou salmouras evaporíticas).

Figura 39. Relação entre os teores de Mn e valores de $\delta^{180}$ dos carbonatos estudados, onde duas tendências de alteração podem ser observadas. A direção (A) indica o aumento da interação com fluídos isotopicamente mais leves (água doce, meteórica ou mistura de ambas), enquanto que a direção (B) indica o aumento da interação com fluídos isotopicamente mais pesados (salmoura evaporítica ou água intersticial).

Figura 40. Correlação do padrão de curva isotópica adquirido para os carbonatos da sucessão estudada (sem escala) com as curvas globais de $\delta^{13} \mathrm{C}$ em (A) e ${ }^{87} \mathrm{Sr} /{ }^{86} \mathrm{Sr}$ em (B), em escala temporal. Os intervalos quimioestratigráficos estão notados em números romanos.

Figura 41. Correlação entre o padrões isotópicos de $\delta^{13} \mathrm{C}$ e ${ }^{87} \mathrm{Sr} /{ }^{86} \mathrm{Sr}$ obtidos em diversas sucessões carbonáticas da Faixa Paraguai em Mato Grosso.

Figura 42. Correlação entre o padrões isotópicos de $\delta^{13} \mathrm{C} \mathrm{e}{ }^{87} \mathrm{Sr} /{ }^{86} \mathrm{Sr}$ da Faixa Paraguai, obtidos para os carbonatos da sucessão de Mato Grosso do Sul (A) e da sucessão estudada (B,C) em Mato Grosso. (*) Boggiani et al. (2005); (**) Grotzinger et al. (1998). 89

Figura 43. Comparação quimioestratigráfica da sucessão estudada com outras sucessões mundiais, mostrando perfeita correlação entre as curvas de $\delta^{13} \mathrm{C}$ e as razões ${ }^{87} \mathrm{Sr} /{ }^{86} \mathrm{Sr}$.......92

Figura 44. Proveniência dos sedimentos terrígenos da Formação Serra Azul, tendo como principais fontes os terrenos do Cráton Amazônico (Tassinari \& Macambira, 1999) mais próximos às áreas estudadas. 


\section{RESUMO}

$\mathrm{O}$ presente trabalho apresenta um estudo de quimioestratigrafia isotópica $(\mathrm{C}, \mathrm{O}, \mathrm{Sr}) \mathrm{de}$ detalhe, realizado numa sucessão carbonática de idade ediacariana da porção extremo norte da Faixa Paraguai, Estado do Mato Grosso. A pesquisa se justifica já que durante o Neoproterozóico a Terra sofreu profundas mudanças climáticas, as quais foram registradas em enigmáticas sucessões compostas de depósitos glaciais recobertos por rochas carbonáticas de clima quente. Estudos recentes mostram que ocorreram, pelo menos, três glaciações neste período, denominadas Sturtiana (ca. $725 \mathrm{Ma}$ ), Marinoana (ca. $635 \mathrm{Ma}$ ) e Gaskierana (580 Ma). $\mathrm{Na}$ tentativa de estabelecer uma correlação global entre as sucessões depositadas neste período, os geopesquisadores têm usado diversas ferramentas, principalmente a quimioestratigrafia isotópica de $\mathrm{C}, \mathrm{O}$ e $\mathrm{Sr}$.

$\mathrm{Na}$ região de estudo, ocorrem diamictitos da Formação Puga recobertos por rochas carbonáticas do Grupo Araras, sobre a qual se depositam os diamictitos e carbonatos da Formação Serra Azul, definida neste trabalho. A sucessão carbonática do Grupo Araras apresentou valores de $\delta^{13} \mathrm{C}$ variando de $-1,7 \%$ (base) a $+4 \%$ (topo) e razões ${ }^{87} \mathrm{Sr} /{ }^{86} \mathrm{Sr}$ entre 0,7075 (na base) e 0,7084 (no topo). Estes valores são semelhantes àqueles encontrados em outras sucessões carbonáticas Marinoanas. Os calcários da Formação Serra Azul apresentaram um valores de $\delta^{13} \mathrm{C}$ entre $-7,5 \%$ e $-3,2 \%$ e razões ${ }^{87} \mathrm{Sr} /{ }^{86} \mathrm{Sr}$ de ca. 0,7086 , típicas das sucessões carbonáticas Gaskieranas. Os resultados isotópicos obtidos neste trabalho, associados às evidências sedimentológicas, sugerem que na história geológica de deposição da Faixa Paraguai ocorreram, pelo menos, duas importantes glaciações. 


\section{ABSTRACT}

This work presents a detailed isotopic $(\mathrm{C}, \mathrm{O}$, and $\mathrm{Sr})$ chemostratigraphic study carried out on the Ediacaran carbonate succession from the northernmost part of the Paraguay Belt, in Mato Grosso, Brazil. The importance of this study is related to the Earth's profound climate changes that took place during the Neoproterozoic, which have been recorded by enigmatic sequences composed of glacial deposits immediately overlain by carbonate rocks typical of warm climate. At least three glaciations are recognized: Sturtian (ca. $725 \mathrm{Ma}$ ), Marinoan (ca. $635 \mathrm{Ma}$ ), and Gaskiers (580 Ma). In order to correlate worldwide the successions deposited in this period and to understand the complex depositional environments, isotopic tools, especially chemostratigraphy, have been widely used.

In the study area diamictites of the Puga Formation are overlain by carbonates of the Araras Group, and these, in turn, are covered by diamictites and carbonates of the Serra Azul Formation, which is defined here. The Araras Group carbonates exhibited $\delta^{13} \mathrm{C}$ values between $1.7 \%$ at the base and $+4 \%$ at the top and ${ }^{87} \mathrm{Sr} /{ }^{86} \mathrm{Sr}$ ratios ranging from 0.7075 at the base to 0.7084 at the very top. These values are similar to those of post-glacial, non-cap Marinoan carbonate successions. The limestones of the Serra Azul Formation yielded $\delta^{13} \mathrm{C}$ values between -7.5 and $-3.2 \%$, and ${ }^{87} \mathrm{Sr} /{ }^{86} \mathrm{Sr}$ ratios of ca. 0.7086 , typical of post-Gaskiers cap carbonates. These isotopic results, together with sedimentological evidence, suggest that two important glaciations occurred during the depositional history of the northernmost Paraguay Belt. 


\section{CAPÍTULO 1 INTRODUÇão}

As rochas depositadas no fim do Neoproterozóico despertam o interesse de vários pesquisadores, principalmente devido aos enigmáticos carbonatos de capa, observados mundialmente associados aos tilitos glaciais. A importância concedida por geopesquisadores a este período geológico se deve à possibilidade da Terra ter sofrido extremas variações climáticas, como defendido pela teoria da Snowball Earth (Kirschvink, 1992; Hoffman et al., 1998), justamente precedendo a chamada "Explosão de Vida Cambriana", período em que a vida evoluiu e se diversificou de maneira rápida e ampla. Atualmente se acredita que houve pelo menos três glaciações Neoproterozóicas, conforme Halverson et al. (2005): Sturtiana (cerca de $725 \mathrm{Ma}$ ), Marinoana (cerca de $635 \mathrm{Ma}$ ) e Gaskiers (580 Ma). Segundo Hoffman et al. (1998), as condições climáticas extremas que reinavam na Terra, levaram à deposição de tilitos seguidos por grande quantidade de carbonatos, com composições isotópicas características, ocorrência expressiva de depósitos de ferro e manganês (característicos de ambientes anóxidos) e estagnação da diversificação da vida. Desta maneira, este período possui variações na composição isotópica da água do mar típicas, especialmente em relação ao carbono $\left(\delta^{13} \mathrm{C}\right)$, oxigênio $\left(\delta^{18} \mathrm{O}\right)$ e estrôncio $\left({ }^{87} \mathrm{Sr} /{ }^{86} \mathrm{Sr}\right)$, influenciadas pelas condições climáticas e ambientais e por alterações nos padrões biológicos. Tais variações são temporais e adquiridas pelos carbonatos no instante da deposição, podendo ser utilizadas no posicionamento estratigráfico e correlação de sucessões de uma mesma bacia ou entre diferentes bacias marinhas. Para o Neoproterozóico existe uma quantidade razoável de dados isotópicos que permite a construção de curvas temporais globais, mas ainda com grandes lacunas. Assim, a aquisição de uma maior quantidade de dados isotópicos de boa qualidade contribui com o aperfeiçoamento destas curvas. Esta é uma técnica que vem sendo aplicada em vários carbonatos neoproterozóicos do mundo, inclusive nos carbonatos da Faixa Paraguai, conforme a literatura existente.

\subsection{JUSTIFICATIVAS}

Poucas seqüências sedimentares registram estas importantes mudanças climáticas que ocorreram no final do Pré-Cambriano. No Brasil, elas podem ser encontradas nos crátons do São Francisco e Amazônico, assim como nas faixas móveis que bordejam estes crátons. Como a 
metodologia a ser aplicada dificilmente forneceria bons resultados em áreas metamórficas, optou-se por escolher a área de maior exposição dos carbonatos não metamorfisados da Faixa Paraguai.

Estudos recentes na Faixa Paraguai (e.g. Alvarenga et al., 2003; Boggiani et al., 2003; Nogueira et al., 2003; Pinho et al., 2003; Ganzer \& Figueiredo, 2004; Alvarenga et al. 2004) produziram muitos dados analíticos, mas também aventaram algumas questões:

1. Qual seria a relação das seqüências que ocorrem na região central do Mato Grosso com aquelas mais a oeste deste Estado e as do Estado do Mato Grosso do Sul?

2. Elas seriam contemporâneas? Representariam registros de uma mesma bacia sedimentar?

3. Esta sucessão sedimentar seria o registro de mudanças climáticas globais ou representaria simplesmente a evolução tectônica da bacia?

Através deste trabalho, utilizando dados sedimentológicos e quimioestratigráficos, pretende-se responder estas questões.

\subsection{OBJETIVOS}

É objetivo desta dissertação mostrar, sob um enfoque semelhante ao realizado em outras seqüências neoproterozóicas por outros pesquisadores, novos dados quimioestratigráficos obtidos para a porção norte da Faixa Paraguai, ainda pouco conhecida faciologicamente e com poucos dados isotópicos disponíveis.

Assim, este trabalho apresenta o detalhamento da unidade predominantemente carbonática, que corresponde ao Grupo Araras, e da unidade glacial (pelitos e carbonatos), que corresponde à Formação Serra Azul, todas depositadas durante o Ediacariano. Este estudo inclui o reconhecimento das diferentes fácies sedimentares e o estudo isotópico de $\mathrm{O}, \mathrm{C}$ e $\mathrm{Sr}$ nestes carbonatos, visando correlacionar a sucessão de rochas pesquisada com outras sucessões da mesma bacia e de outras bacias marinhas de mesma idade, previamente estudadas por outros pesquisadores. 


\section{CAPÍTULO 2 FUNDAMENTAÇÃO TEÓRICA}

Neste capítulo procura-se abordar os fundamentos teóricos que embasaram a presente pesquisa, por meio da apresentação de hipóteses, princípios e conceitos, elaborados por diversos pesquisadores de prestígio, encontrados na literatura mundial, dando-se ênfase no entendimento da Hipótese Snowball Earth, Quimioestratigrafia e Estudo de Proveniência de Sedimentos.

\subsection{A HIPÓTESE SNOWBALL EARTH}

Idéias catastróficas são geralmente bastante debatidas no meio geológico. No caso da Hipótese Snowball Earth não seria diferente, embora esta tenha ganhado certa aceitação devido ao intenso trabalho de Paul Hoffman no seu aprimoramento e divulgação. Por ser esta a hipótese que melhor explica a grande maioria das feições geológicas encontradas ao redor do mundo (Tabela 1) e na área de estudo pesquisada, optou-se por uma explanação maior sobre ela, enquanto se faz menções menores a outras hipóteses.

Tabela 1. Características Glaciais Proterozóicas e as Hipóteses que as explicam, modificado de Kirschivink (2002).

\begin{tabular}{|l|c|c|c|c|c|}
\cline { 2 - 6 } \multicolumn{1}{l|}{} & $\begin{array}{c}\text { Hard } \\
\text { Snowball }\end{array}$ & 'Slushball' & $\begin{array}{c}\text { Alta } \\
\text { obliquidade }\end{array}$ & $\begin{array}{c}\text { Zipper- } \\
\text { Rift }\end{array}$ & $\begin{array}{c}\text { Estilo } \\
\text { Fanerozóico }\end{array}$ \\
\hline $\begin{array}{l}\text { Abundantes clastos } \\
\text { carbonáticos em tilitos. }\end{array}$ & Sim & Sim & Não (?) & Sim & Não (?) \\
\hline $\begin{array}{l}\text { Deposição de tilitos em baixa } \\
\text { latitude. }\end{array}$ & Sim & Sim & Sim (?) & Sim & Não \\
\hline $\begin{array}{l}\text { Associação com BIFs “vent- } \\
\text { derived” }\end{array}$ & Sim & Não & Não & Sim & Não \\
\hline $\begin{array}{l}\text { Associação de depósitos de } \\
\text { Mn hospedados em BIF. }\end{array}$ & Sim & Não & Não & Não & Não \\
\hline $\begin{array}{l}\text { Presença de carbonatos de } \\
\text { capa. }\end{array}$ & Sim & Não & Não & Não & Não \\
\hline $\begin{array}{l}\text { Excursões negativas de } \delta^{13} \mathrm{C} \\
\text { Sim }\end{array}$ & Sim & Sim (?) & Não (?) & Sim & Não \\
\hline $\begin{array}{l}\text { Intervalos com chuva de } \\
\text { detritos glacial. }\end{array}$ & Não (?) & Sim & Sim (?) & Não & Sim \\
\hline
\end{tabular}




\subsubsection{Construção da Hipótese Snowball Earth}

A idéia que a Terra tivesse congelado totalmente alguma vez foi primeiramente proposta por Louis Agassiz, para explicar a extinção em massa de uma megafauna pela repentina chegada de um severo inverno siberiano mundial. Ele chamou tal evento/idéia de Great Ice Age e o defendeu por toda sua vida desde 1837, no seu famoso Discurso de Neuchatel, onde enfrentou a violenta desaprovação dos colegas (Agassiz, 1840; Bolles, 1999). Agassiz estava certo de que existiram campos de gelo muito mais extensos no passado que os de agora, porém errou ao afirmar que as idades do gelo mais recentes também se estenderam ao equador.

Um geólogo britânico, Brian Harland, da Cambridge University foi o primeiro a afirmar que existiam evidências paleomagnéticas de geleiras em zonas tropicais (Harland \& Bidgood, 1959). Após a II Guerra Mundial, Harland foi a um pequeno arquipélago no extremo ártico do Atlântico Norte, chamado Svalbard, para um programa de pesquisa geológica. Durante a etapa de campo encontrou carbonatos oolíticos abaixo e acima de diamictitos glaciais e postulou que ou Svalbard esteve alguma vez no equador, ou mudanças climáticas globais produziram condições tropicais no Ártico, ou uma combinação de ambos. Chamou a este evento de Great Infra-Cambrian Glaciation (Harland, 1965; Harland \& Rudwick, 1965). Sua idéia não teve muita força na época, pois outros pesquisadores afirmavam que os diamictitos de Svalbard não eram glaciais, mas de escorregamentos marinhos (Walker, 2003, 2004).

Joseph Kirschvink do Caltech (California Institute of Technology) ficou intrigado com um artigo sobre depósitos glaciais no Sul da Austrália com campo magnético indicando origem equatorial. Recebeu de um paleontólogo, Bruce Runnegar, uma amostra de siltito rítmico daquela mesma localidade, que entregou a sua bolsista Dawn Sumner para um estudo paleomagnético (Hoffman \& Schrag, 2002). Os resultados sugeriram a deposição próxima ao equador (Sumner et al., 1987). Isso levou Kirschivink a formular uma teoria notavelmente cheia de detalhes a que chamou de Snowball Earth (Kirschivink, 1992).

Paul Hoffman conversou pessoalmente com Joseph Kirschvink sobre a idéia Snowball Earth e passou a se dedicar ao desenvolvimento desta hipótese. Durante sua pesquisa de campo, encontrou tilitos depositados acima e abaixo de carbonatos na Namíbia, que o intrigaram. Os fatos começaram a serem explicados quando ele se juntou ao criterioso colega de Harvard, Dan Schrag, especialista em carbonatos e paleoclima (Walker, 2003, 2004). Hoffman, quando reuniu evidências suficientes, viajou pelo mundo geológico profissional dando apresentações de suporte para a Snowball Earth. Seu esforço gerou aceitação por muitos que passaram a contribuir com a geração de mais dados, mas também propiciou o surgimento de outras idéias, alternativas a tal 
hipótese, que possam explicar as feições geológicas encontradas sob outra ótica, como: a obliqüidade orbital da Terra (Williams, 1975, 1993, 2000), anéis de gelo em órbita da Terra (Sheldon, 1984) e Zipper-Rift (Eyles \& Januszczak, 2004), brevemente descritas mais adiante, neste capítulo.

\subsubsection{Resumo da Hipótese Snowball Earth}

A Hipótese Snowball Earth (Terra Bola de Neve), também chamada Hard Snowball (Kirschivink, 2002), consiste basicamente da idéia de que o Planeta Terra foi, num passado remoto, inteiramente congelado, que poderia explicar a grande quantidade de sedimentos descritos como glaciais depositados em baixas latitudes ao redor do mundo. A Hipótese como tal foi proposta inicialmente por Kirschivink (1992) e posteriormente aperfeiçoada por Hoffman et al. (1998) e Hoffman \& Schrag (2000). Os mecanismos de início, manutenção e fim deste evento catastrófico são resumidos aqui em 4 estágios (Figura 1), baseado em Hoffman \& Schrag (2000 e 2002), para melhor entendimento.

\section{Estágio 1: Prólogo da Snowball Earth}

O intemperismo de rochas siliclásticas teria causado uma diminuição do teor de dióxido de carbono na atmosfera, resultando num resfriamento da Terra. Com continentes em altas latitudes, qualquer resfriamento resultaria nas rochas sendo cobertas com neve e gelo, o que controlaria os processos intempéricos e reduziria a remoção de $\mathrm{CO}_{2}$ da atmosfera. No entanto, se os continentes estivessem todos localizados em baixas latitudes, a acumulação de gelo e neve nas altas latitudes não diminuiria o carreamento de $\mathrm{CO}_{2}$ da atmosfera e o resfriamento continuaria até atingir o equador (Figura 1).

Assim, a quebra de um único continente há 770 Ma deixaria pequenos continentes espalhados próximo ao equador (Kirschivink, 1992), configuração não mais encontrada na história da Terra (Figura 1). Áreas internas do continente de outrora, antes com clima mais seco, se tornariam bloqueadoras para fonte oceânica de umidade. Com isso a chuva aumentaria e carrearia mais dióxido de carbono, aprisionado pelo calor, para fora do ar e erodiria as rochas continentais mais rapidamente. Conseqüentemente, a temperatura global cairia e grandes pacotes de gelo se formariam nos oceanos polares (Marshall et al., 1988; Worsley \& Kidder, 1991). O gelo branco refletiria a energia solar (Albedo) mais que a água escura do mar e levaria às temperaturas sempre mais baixas (Budyko, 1969), ressaltando que a luminosidade solar há 600700 Ma atrás era 6\% menor que a atual (Figura 2), devido à evolução estelar (Caldeira \& 
Kasting, 1992). Este ciclo de realimentação provocaria um incontrolável efeito de resfriamento (Budyko, 1969; Sellers, 1969), que mergulharia o planeta no gelo dentro de um milênio.

\section{CENÁRIO DA SNOWBALLEARTH}
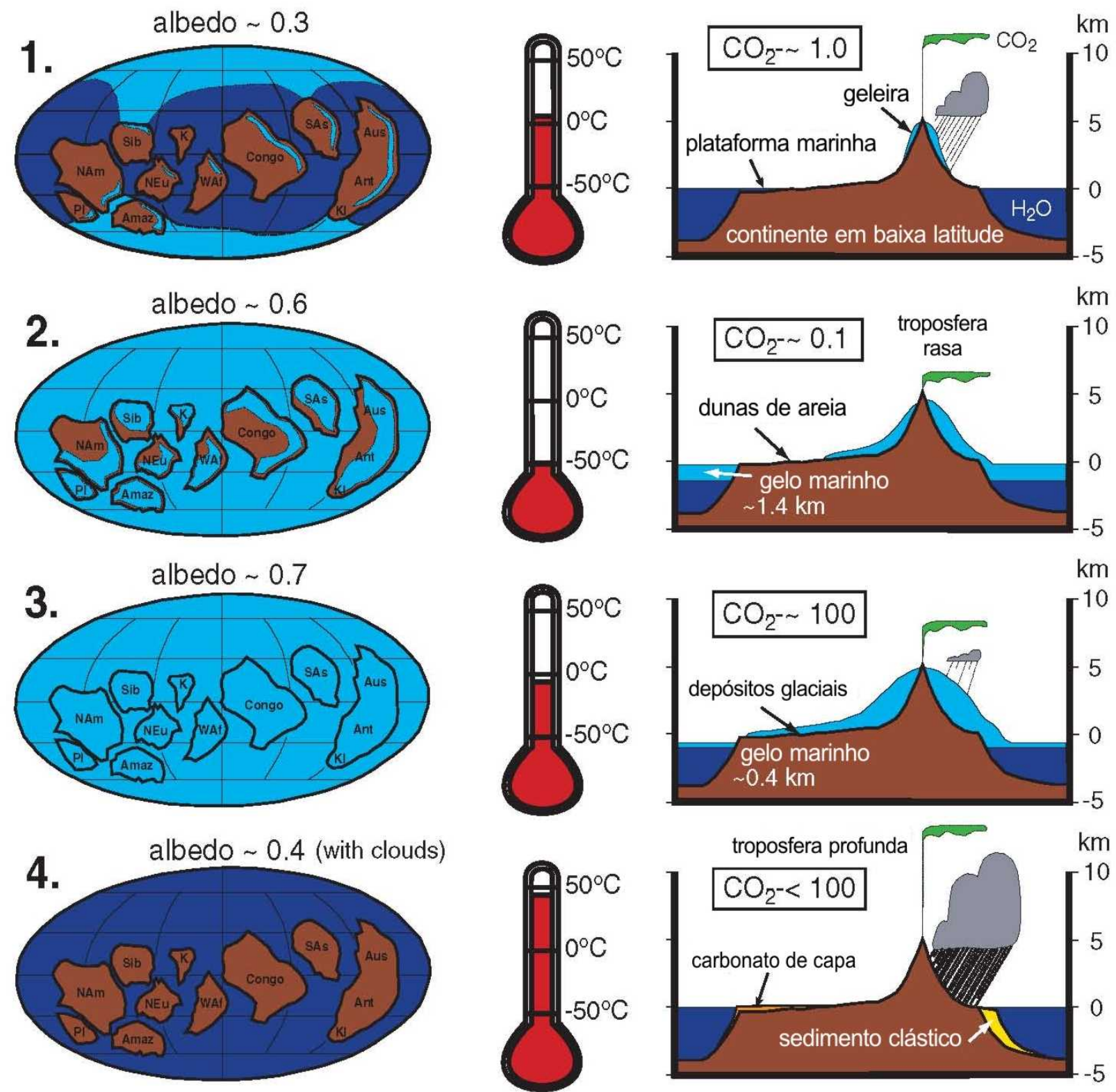

Figura 1. Os quatro estágios da hipótese Snowball Earth, apresentando as variações no albedo planetário, dióxido de carbono atmosférico, temperatura superficial, profundidade troposférica, precipitação, extensão glacial e profundidade do gelo marinho (modificado de Hoffman \& Schrag, 1999). 


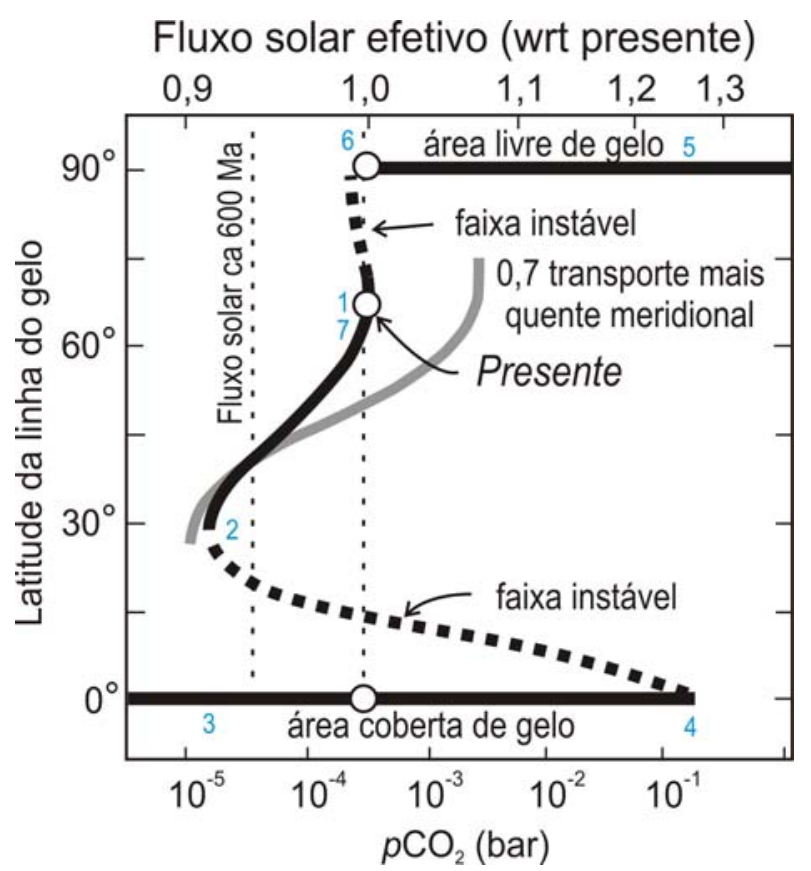

Figura 2. Gráfico baseado num modelo simples de balanço de energia do tipo Budyko-Sellers (modificado de Hoffman e Schrag, 2002), mostrando a latitude da linha de gelo (ao nível do mar) como uma função do fluxo solar efetivo (Es), ou equivalente para $p \mathrm{CO}_{2}$ (para Es $1 / 41,0$ ). O efeito de uma redução de $30 \%$ no transporte meridional mais quente é apresentado (linha cinza), como o fluxo solar estimado há ca. $\sim 600 \mathrm{Ma}$. Iniciando do ponto 1 , a redução de $\boldsymbol{p} \mathrm{CO}_{2}$ provoca a migração constante das linhas de gelo para o ponto 2 (linha cheia), onde a realimentação descontrolada do albedo leva as linhas de gelo à área coberta de gelo no ponto 3. A emanação normal de gases vulcânicos por milhões de anos aumenta a $p \mathrm{CO}_{2}$ para o ponto 4 , iniciando a deglaciação. A realimentação inversa do albedo do gelo, leva rapidamente as linhas de gelo à área sem gelo, no ponto 5 , onde a alta $\mathrm{pCO}_{2}$ e o baixo albedo planetário produz uma ultra-estufa transitória. $\mathrm{O}$ intemperismo silicático intensificado provoca a redução de $\boldsymbol{p} \mathrm{CO}_{2}$ ao ponto 6 , conseqüentemente as capas de gelo polar se refazem e as linhas de gelo voltam à área parcialmente coberta de gelo, no ponto 7.

Estágio 2: Snowball Earth no seu resfriamento

A temperatura média global cairia a $-50{ }^{\circ} \mathrm{C}$ (Figura 1) abruptamente após o início do congelamento descontrolado (Walker, 2001). O gelo dos oceanos atingiria profundidades de cerca de 1,4 kilômetros para um albedo de 0,6 (Figura 1), lentamente limitada apenas por emanações quentes do interior da Terra (Walker, 2001), o que tornaria os mares anóxidos e repletos de $\mathrm{Fe}^{+2}$ dissolvido (Figura 3). A maioria dos organismos microscópicos marinhos teria morrido, mas um pequeno número teria lutado pela vida em fontes quentes vulcânicas (Kirschivink, 1992). O ar seco e frio controlaria o crescimento das geleiras continentais, criando vastos desertos de areia transportadas pelo vento. Sem chuva, o $\mathrm{CO}_{2}$ continuamente emitido pelos vulcões não seria removido da atmosfera (Kirschivink, 1992). Com o acúmulo de $\mathrm{CO}_{2}$, o planeta esquentaria e o gelo dos mares vagarosamente afinaria. 


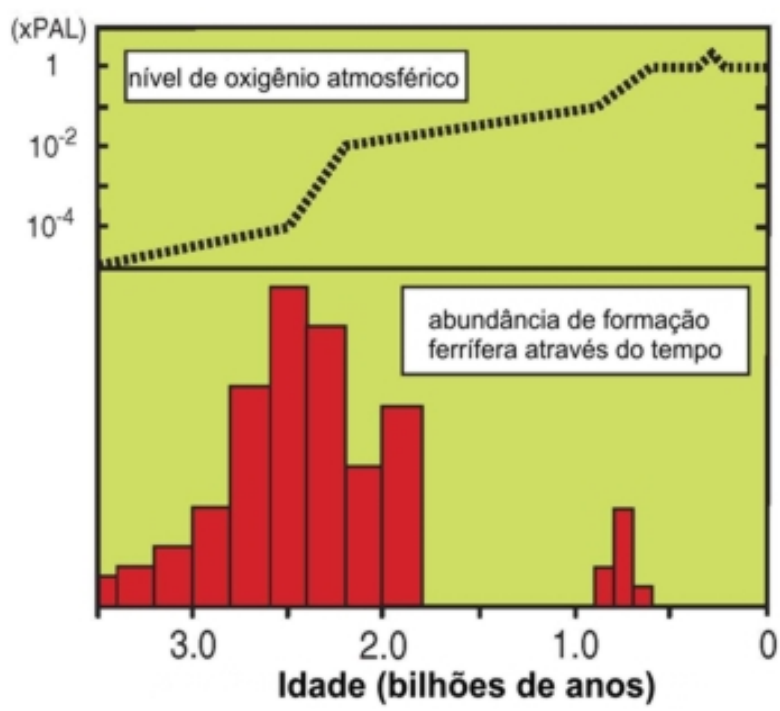

Snowball earth: oceano anóxido
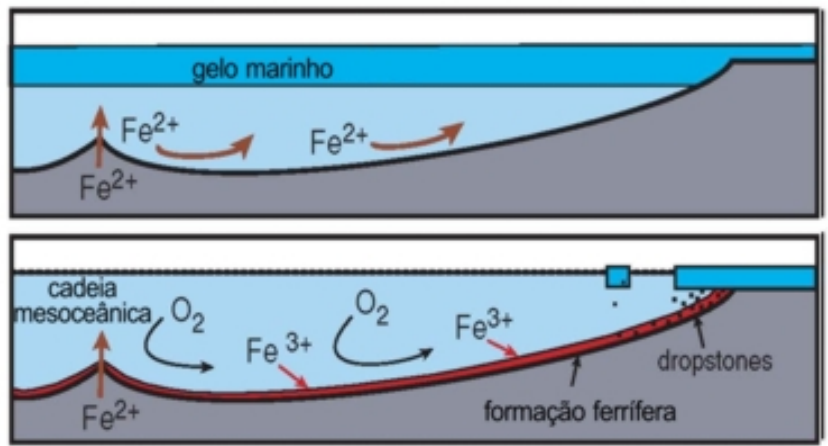

Deglaciação: oxidação oceânica

Figura 3. Gráfico das ocorrências de formações ferríferas sedimentares através do tempo geológico, à esquerda, e mecanismo de deposição do ferro numa situação de Snowball Earth, diagrama à direita (modificado de Hoffman e Schrag, 1999). Se o oxigênio $\left(\mathrm{O}_{2}\right)$ é ausente, o ferro é solúvel como íon ferroferroso $\left(\mathrm{Fe}^{2+}\right)$, enquanto que na presença de $\mathrm{O}_{2}$ o ferro é insolúvel como íon ferro-férrico $\left(\mathrm{Fe}^{3+}\right)$.

\section{Estágio 3: Snowball Earth, como ela descongela}

De acordo com a hipótese, concentrações de $\mathrm{CO}_{2}$ aumentariam consideravelmente como resultado de 10 Ma de atividade vulcânica normal. Para se superar o frio intenso, seria necessário uma pressão de dióxido de carbono cerca de 0,12 bar, aproximadamente 350 vezes maior que a atual (Caldeira \& Kasting, 1992). O aquecimento resultante do avanço do efeito estufa levaria a temperatura ao ponto de fusão no equador. Conforme o planeta aquecia, a umidade do gelo marinho, sublimando próximo ao equador, seria refrigerada nas elevações mais altas, sazonalmente, e alimentaria o crescimento de geleiras continentais e afinaria o gelo marinho a cerca de 0,4 kilômetros de espessura (Walker, 2001). A água exposta, que eventualmente se formaria nos trópicos, absorveria mais energia solar e iniciaria uma rápida elevação na temperatura global (Figura 1). Numa questão de séculos, um mundo brutalmente quente e úmido suplantaria o congelamento profundo (Kirschivink, 1992).

\section{Estágio 4: $\underline{\text { Conseqüente Greenhouse (estufa) }}$}

Como os oceanos tropicais degelariam, a água do mar evaporaria e a umidade trabalharia junto com o carbono para produzir condições de estufa muito mais intensas (Kirschivink, 1992). Tão logo os oceanos fossem descobertos, ocorreria a oxigenação da água e o $\mathrm{Fe}^{+2}$ dissolvido se transformaria em $\mathrm{Fe}^{+3}$ e precipitaria (Figura 3), gerando as formações ferríferas e os depósitos de manganês neoproterozóicos (Kirschivink, 1992, 2002). Temperaturas superficiais elevam-se à 
cerca de $50{ }^{\circ} \mathrm{C}$ (Figura 1), levando a um ciclo intenso de evaporação e precipitação (Walker, 2001). Torrentes de chuva ácida carbônica erodem os fragmentos de rocha depositados como resultado do recuo das geleiras (Kirschivink, 1992; Caldeira \& Kasting, 1992). Rios cheios carreiam bicarbonato e outros íons para dentro dos oceanos, depositando sedimentos carbonáticos (Tabela 2). Novas formas de vida, geradas por isolamento genético prolongado e pressão seletiva, povoaram o mundo conforme o clima volta ao normal.

Tabela 2. Reações em cadeia do intemperismo de carbonatos e silicatos, transporte dos cátions dissolvidos e deposição de novos minerais. Importante notar que, em ambos os casos, são depositados novos carbonatos.

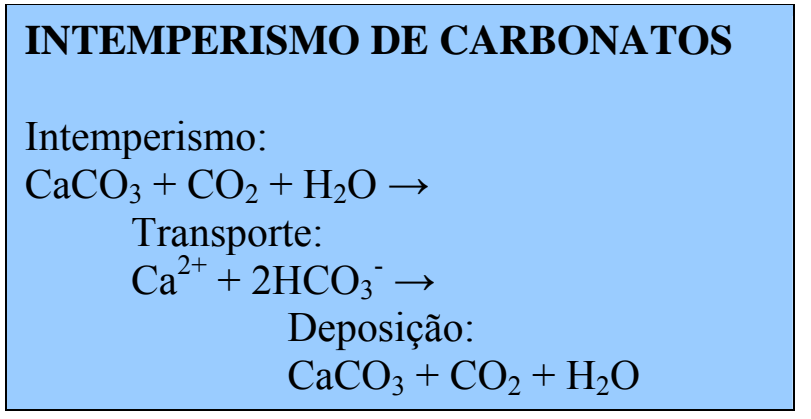

\section{INTEMPERISMO DE SILICATOS}

Intemperismo: $\mathrm{CaSiO}_{3}+2 \mathrm{H}_{2} \mathrm{O}+2 \mathrm{CO}_{2} \rightarrow$

Transporte:

$$
\mathrm{Ca}^{2+}+2 \mathrm{HCO}_{3}^{-}+2 \mathrm{H}^{+}+\mathrm{SiO}_{3}{ }^{2+} \rightarrow
$$

Deposição:

$\mathrm{CaCO}_{3}+\mathrm{SiO}_{2} \cdot \mathrm{H}_{2} \mathrm{O}+\mathrm{CO}_{2}$

Com o reinício do ciclo, através da diminuição de $\mathrm{CO}_{2}$ da atmosfera pelo intenso intemperismo das rochas, o processo congelante poderia recomeçar. Este ciclo seria quebrado apenas quando movimentos tectônicos mudassem as massas continentais emersas para longe do equador (Kirschvink, 1992). O congelamento teria ocorrido não apenas uma, mas um número de vezes em, talvez, mais de um episódio de congelamento e derretimento.

\subsubsection{Outras Hipóteses em Contraste}

\subsubsection{Hipótese da alta obliqüidade orbital}

George Williams após muito mapear os diamictitos glaciais australianos e verificar que estes foram depositados em baixas latitudes, postulou uma idéia diferente para explicar a ocorrência dos mesmos. Williams $(1975,1993,2000)$ propôs que a obliqüidade da Terra, ângulo entre o eixo do spin e o eixo do plano eclíptico, seria maior que 54 graus, podendo chegar a 90 graus (Figura 4), antes do término do Proterozóico, quando mudaria rapidamente para valores próximos dos 23,5 graus atuais, devido ao gigante impacto que levaria à formação da Lua. Tal inclinação propiciaria uma incidência solar anual maior nos pólos que nos trópicos. Durante o solstício, o sol permaneceria perpetuamente alto nos pólos e oscilaria próximo ao horizonte no equador, enquanto que no equinócio, o equador assumiria um verão normal, com dias e noites 
definidos. Estudos comparativos de estromatólitos heliotrópicos atuais e antigos afirmam que a obliqüidade da Terra diferia dos valores atuais há 850 Ma (Vanyo \& Awramik, 1982). Isso geraria forte sazonalidade e fortíssimos ventos superficiais, que, segundo Williams, explicaria as estruturas tipo polígonos de cunha de gelo, encontradas no sul da Austrália, produzidas por variações sazonais de temperatura em solos congelados. A obliqüidade da Terra, segundo Laskar et al. (1993), se auto-estabilizaria pela interação de sua protuberância equatorial remanescente com a Lua. Williams (1993) estima que a diminuição da obliqüidade iniciaria por volta de 600 Ma.

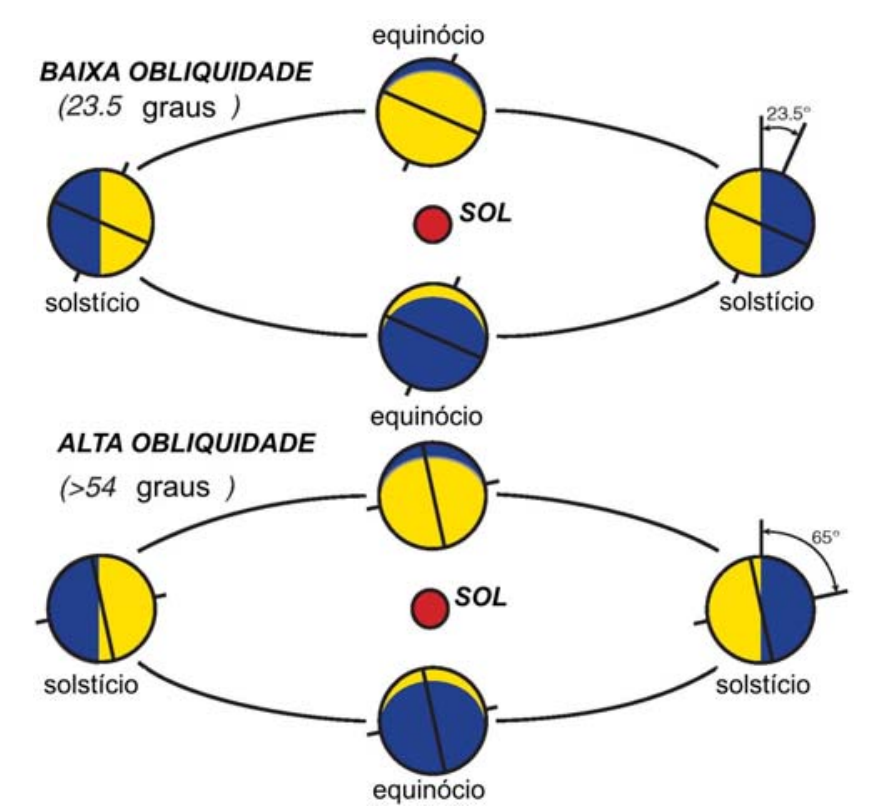

Figura 4. Para uma obliqüidade maior que $54^{\circ}$, as temperaturas seriam mais baixas nos trópicos que nos pólos, sendo a glaciação de baixa latitude causada unicamente pela sazonalidade extrema (modificado de Hoffman \& Schrag, 1999).

\subsubsection{Hipótese dos anéis de gelo em órbita da Terra}

Esta é uma hipótese não muito difundida, idealizada por Richard Sheldon (1984), na qual propõe que, num passado remoto, a Terra possuiu anéis de gelo em sua órbita, semelhante ao que ocorre com os planetas Saturno, Urânio e Netuno, e que, durante todo Proterozóico, pedaços de gelo episodicamente cairiam na atmosfera. Isso originaria, aos poucos, a atmosfera e hidrosfera terrestres, além de um escudo protetor da luz solar no equador. Sem o calor solar, haveria possibilidade das geleiras se formarem em baixas latitudes e o gradual desaparecimento destes anéis levaria ao aquecimento da Terra até as condições atuais.

No caso de Saturno (Figura 5), seus anéis de gelo são mantidos em órbita por seus vários satélites, sem os quais os anéis colapsariam. A sombra dos anéis migra sazonalmente. Uma situação similar na Terra explicaria as intercalações de sedimentos aparentemente depositados 
sob variações climáticas extremas. Neste cenário, a Terra pré-Arqueana possuía uma atmosfera quente e fina e um anel de gelo espesso em redor do planeta. No Arqueano, alguns dos elementos atmosferíveis do anel de gelo teriam sido transferidos para atmosfera terrestre, que era fina, fria e reduzida, e para os oceanos primitivos, que eram ácidos e pequenos. As geleiras eram comuns.

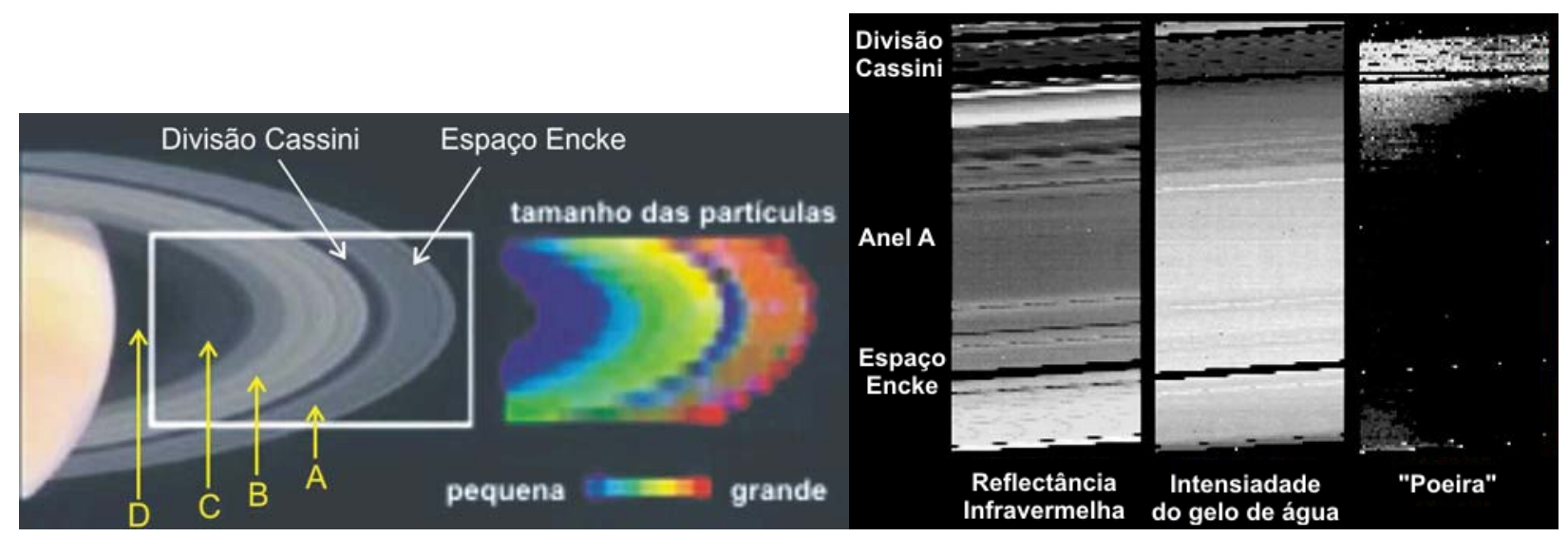

Figura 5. Imagens dos anéis de Saturno feitas pela sonda Cassini. À esquerda podem-se observar os quatro anéis mais internos (dos sete que possui), com detalhe da composição granulométrica, adquirida por espectrômetro de mapeamento infravermelho. As partículas dos anéis de saturno são compostas essencialmente por gelo de água (conforme detalhe do anel $\mathrm{A}$, à direita) e variam em tamanho de mícrons a dezenas de metros. Os principais anéis (A, B e C) são relativamente jovens e possuem poucas centenas de milhões de anos e devem ter se formado pela quebra de um satélite, ou de um cometa ou meteoro capturado pela gravidade de saturno (modificado de Nasa, 2004; Doherty \& Wegryn, 2004).

O aumento simultâneo da distância entre a Lua e a Terra causaria instabilidades no anel de gelo durante este período e este se desmembraria em três anéis distintos. Sheldon (1984) defende que cada anel de gelo seria responsável por cada um dos três maiores períodos glaciais, refletida nos oceanos proterozóicos que permutavam entre gélidos e quentes, reduzidos e oxidados.

\subsubsection{Hipótese Zipper-Rift}

Uma das hipóteses que mais duramente se opõe à Snowball Earth é a desenvolvida por Nicholas Eyles e Nicole Januszczak denominada Zipper-Rift, na qual fazem uma revisão sistemática do modelo Snowball Earth, num artigo de 74 páginas (Eyles \& Januszczak, 2004), enfatizando as evidências sedimentológicas e estratigráficas atuais para sedimentos glaciais, integradas ao contexto tectônico neoproterozóico. Assim, os autores questionam várias evidências do modelo Snowball Earth, como: (i) a origem glacial de vários sedimentos descritos na literatura como "tilitos", (ii) os registros paleomagnéticos que podem ter sido readquiridos em qualquer época após a sedimentação, ao passo que as idades de vários destes diamictitos ainda 
não são bem determinadas, (iii) as formações ferríferas se depositariam também em bacias tipo rift em estágio inicial devido à atividade hidrotermal e não apenas em mares isolados da atmosfera por uma camada de gelo, (iv) deposição de carbonatos logo acima de diamictitos 'tectônicos' como resultado da diminuição da subsidência que permitisse condições plataformais, (v) as mudanças nos valores isotópicos de $\mathrm{C}$ poderia ser explicado pela tectônica global e intensa atividade vulcânica (Figura 6), especialmente pelo rápido soterramento (subsidência) de carbono orgânico em novas bacias de rift.

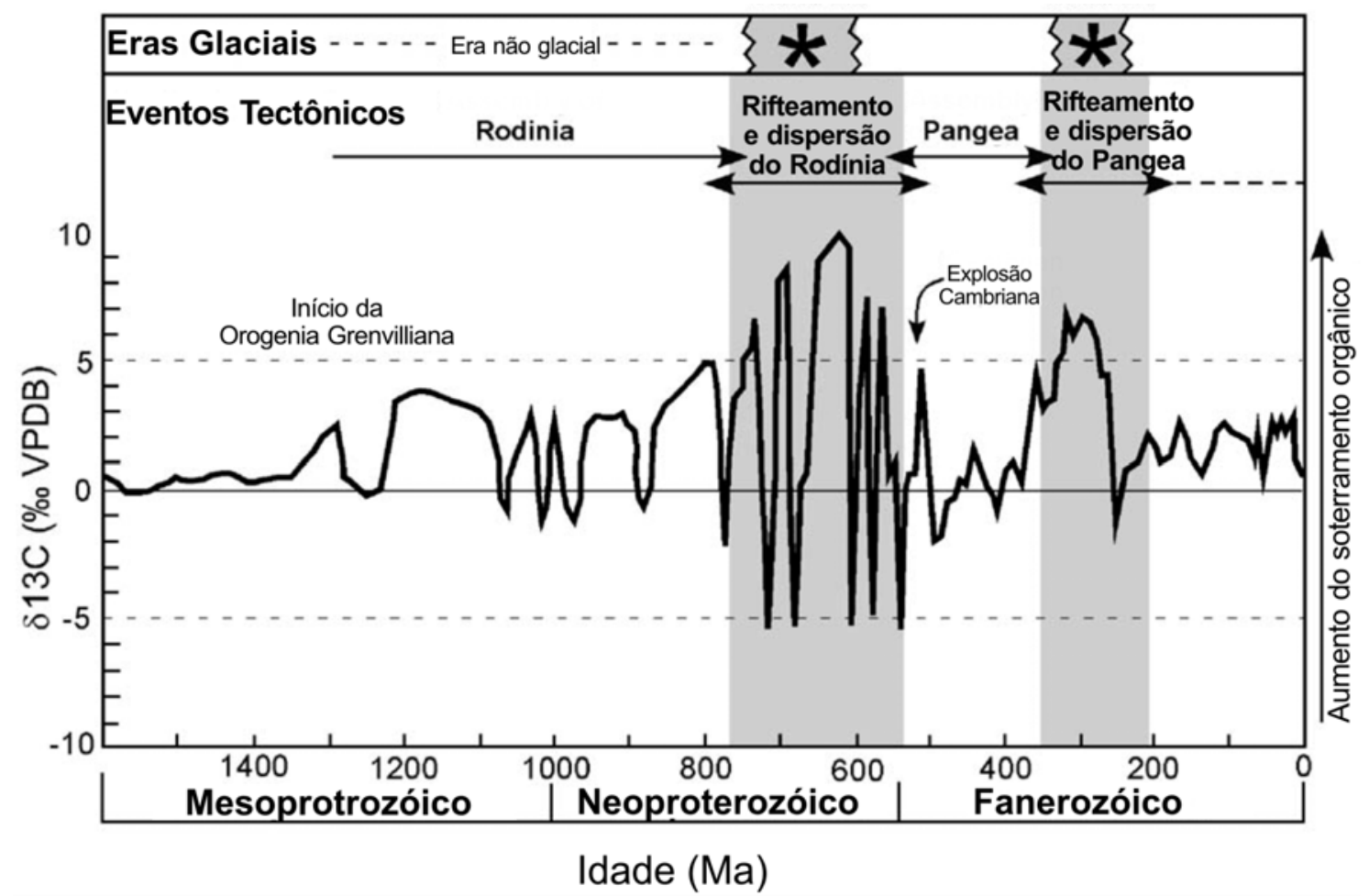

Figura 6. Eras tidas como glaciais e variação isotópica do carbono no contexto dos ciclos tectônicos globais. De acordo com Eyles \& Januszczak (2004), o rifteamento de supercontinentes parece estar associado às notáveis excursões isotópicas, refletindo tão somente o aumento do soterramento do carbono orgânico em bacias tipo rift recém formadas e com alta taxa de subsidência (modificado de Eyles \& Januszczak, 2004).

A Hipótese Zipper-Rift consiste de uma proposta alternativa para as "glaciações neoproterozóicas" (Eyles \& Januszczak, 2004), segundo a qual a quebra do supercontinente Rodínia, que ocorreu entre 750 e 610 Ma atrás, seria registrada por seqüências tectonoestratigráfica diacrônicas bem definidas depositadas em bacias marinhas tipo rift. A base de cada sucessão consistiria de diamictitos e conglomerados sin-rift e de fluxo de massa subaquoso, estando intercaladas com amplos olistrostomas e contendo clastos carbonáticos derivados de deslizamentos de escarpas de falha ao longo das plataformas carbonáticas rifteadas. Tais sedimentos ocorreriam também dentro de espessos turbiditos de rampa, devido à acentuada subsidência, e seriam capeados por sedimento marinho raso, como registro da redução da 
subsidência e arrasamento da bacia. Algumas sucessões apresentariam clara influência glacial, como resultado de forte elevação tectônica pré-rift (glaciação de altitude) ou da latitude (Figura 7), registrando um ciclo hidrológico completo, em desarmonia com um planeta completamente congelado. O mapeamento destes depósitos aparentemente glaciais mostra que tais glaciações neoproterozóicas foram regionais ou hemisféricas. De acordo com os autores, os ciclos tectonoestratigráficos podem atingir vários kilômetros de espessura, mas vêm sendo erroneamente interpretados como registros glacioeustático globalmente sincrônico.
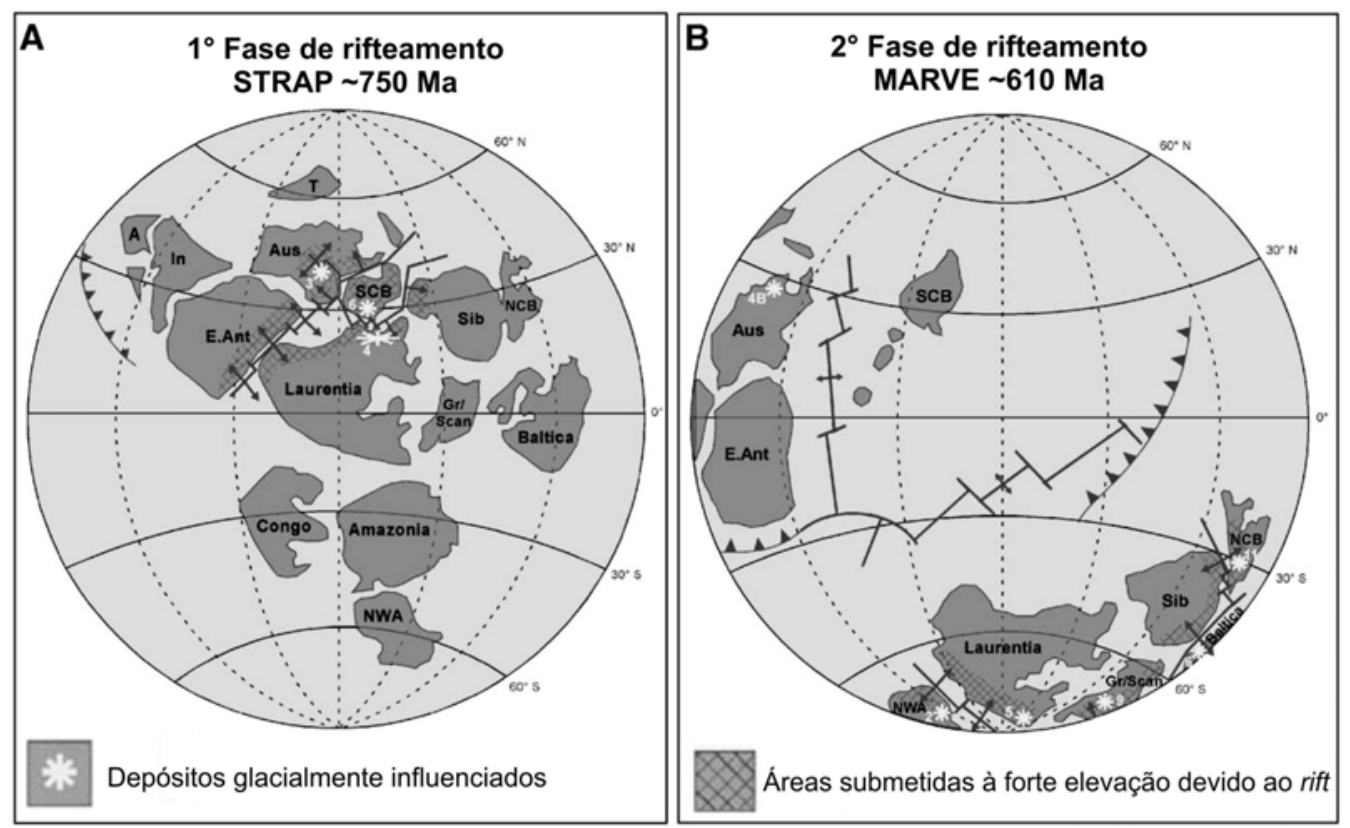

Figura 7. Nos quadros A e B está representado o rifteamento como um evento sincrônico, porém a quebra dos blocos continentais seria na forma de um 'zipper'. Em A, a primeira fase do rifteamento do Rodinia após $750 \mathrm{Ma}$, com a abertura do oceano Paleo-Pacífico. Em B, a segunda fase do rifteamento do Rodinia por volta de $650 \mathrm{Ma}$, com a abertura do oceano Iapetus (modificado de Eyles \& Januszczak, 2004).

\subsection{QUIMIOESTRATIGRAFIA}

A quimioestratigrafia consiste no estudo isotópico de seqüências sedimentares em conjunto com rigoroso controle litoestratigráfico, como ferramenta no entendimento das condições de sedimentação e na correlação entre seções de uma mesma bacia ou de bacias diferentes, no caso de sedimentos marinhos. Comumente se utiliza, para tal estudo, as razões isotópicas medidas em isótopos estáveis $\left({ }^{13} \mathrm{C} /{ }^{12} \mathrm{C}\right.$ e $\left.{ }^{18} \mathrm{O} /{ }^{16} \mathrm{O}\right)$ e radiogênicos $\left({ }^{87} \mathrm{Sr} /{ }^{86} \mathrm{Sr}\right)$, de rochas carbonáticas. Há grande interesse na utilização deste método em carbonatos proterozóicos devido à escassez de fósseis em seqüências deste Eon e ao insucesso dos estromatólitos como recurso bioestratigráfico. Vários autores tentam estabelecer curvas globais de variação temporal que auxiliem na determinação relativa das idades de seqüências mais antigas, especialmente para 
o Neoproterozóico (Knoll \& Walter, 1992; Kaufman \& Knoll, 1995; Veizer et al., 1999; Jacobsen \& Kaufman, 1999; Walter et al., 2000; Melezhik et al., 2001; Halverson et al., 2005), marcado por importantes eventos geológicos.

\subsubsection{Isótopos estáveis de C e $\mathrm{O}$}

As composições isotópicas de $\mathrm{C}$ e $\mathrm{O}$ são medidas conjuntamente através das razões entre seus respectivos pares isotópicos $\left({ }^{13} \mathrm{C} /{ }^{12} \mathrm{C}\right.$ e $\left.{ }^{18} \mathrm{O} /{ }^{16} \mathrm{O}\right)$ e transformadas em notação delta $\left(\delta^{13} \mathrm{C}\right.$ e $\left.\delta^{18} \mathrm{O}\right)$ pela comparação com um padrão, sendo o valor dado em partes por mil: $\delta=1000$ (amostra/padrão) -1. O padrão usado é correspondente ao valor da razão isotópica de uma concha de Belemnite cretácea da Formação Pee Dee (South Carolina, Estados Unidos), representado pela sigla $\mathrm{PDB}$.

Existem dois reservatórios destes isótopos: o interno, formado pelas rochas e manto, e o externo, formado pela atmosfera, biosfera, hidrosfera e sedimentos inconsolidados (Schidlowski et al., 1983). A transferência isotópica do reservatório interno para o externo se dá por processos geológicos como vulcanismo, metamorfismo (fluídos) e intemperismo; enquanto que o inverso se dá pela precipitação de sedimentos, assumindo a composição isotópica da água no momento da precipitação. Os processos de fracionamento isotópico diferem para $\mathrm{C}$ e $\mathrm{O}$, como explanado adiante.

\subsubsection{Fracionamento isotópico do C}

Dentre os mecanismos que causam o fracionamento isotópico de $\mathrm{C}$ pode-se citar a fotossíntese, enquanto que para as variações isotópicas, os padrões de circulação da água, de ambientes marinho ou restrito seriam os principais responsáveis (Figura 8).

\subsubsection{Fotossíntese}

A fotossíntese é um dos principais processos de fracionamento isotópico do $\mathrm{C}$, de forma que concentra ${ }^{12} \mathrm{C}$ (mais leve) na matéria orgânica produzida, fazendo com que o meio onde se encontra (água do mar) seja enriquecido em ${ }^{13} \mathrm{C}$, passando a ter um $\delta^{13} \mathrm{C}$ positivo. Desta forma, o inverso ocorre na matéria orgânica, resultando a fotossíntese num $\delta^{13} \mathrm{C}$ de $-20 \%$. Sob uma atmosfera de $\delta^{13} \mathrm{C}$ igual a $-7 \%$, a fotossíntese produziria massas vegetais com $\delta^{13} \mathrm{C}$ cerca de 27\%o (Schidlowski et al., 1983). Assim, num dado ambiente marinho, se há intensa atividade biológica, os valores $\delta^{13} \mathrm{C}$ são bastante positivos na água do mar e, conseqüentemente, nos 
carbonatos precipitados a partir dela. Contudo, se inexiste atividade biológica, um ambiente aquático apresentará valores $\delta^{13} \mathrm{C}$ negativos, assim como os carbonatos neleprecipitados.

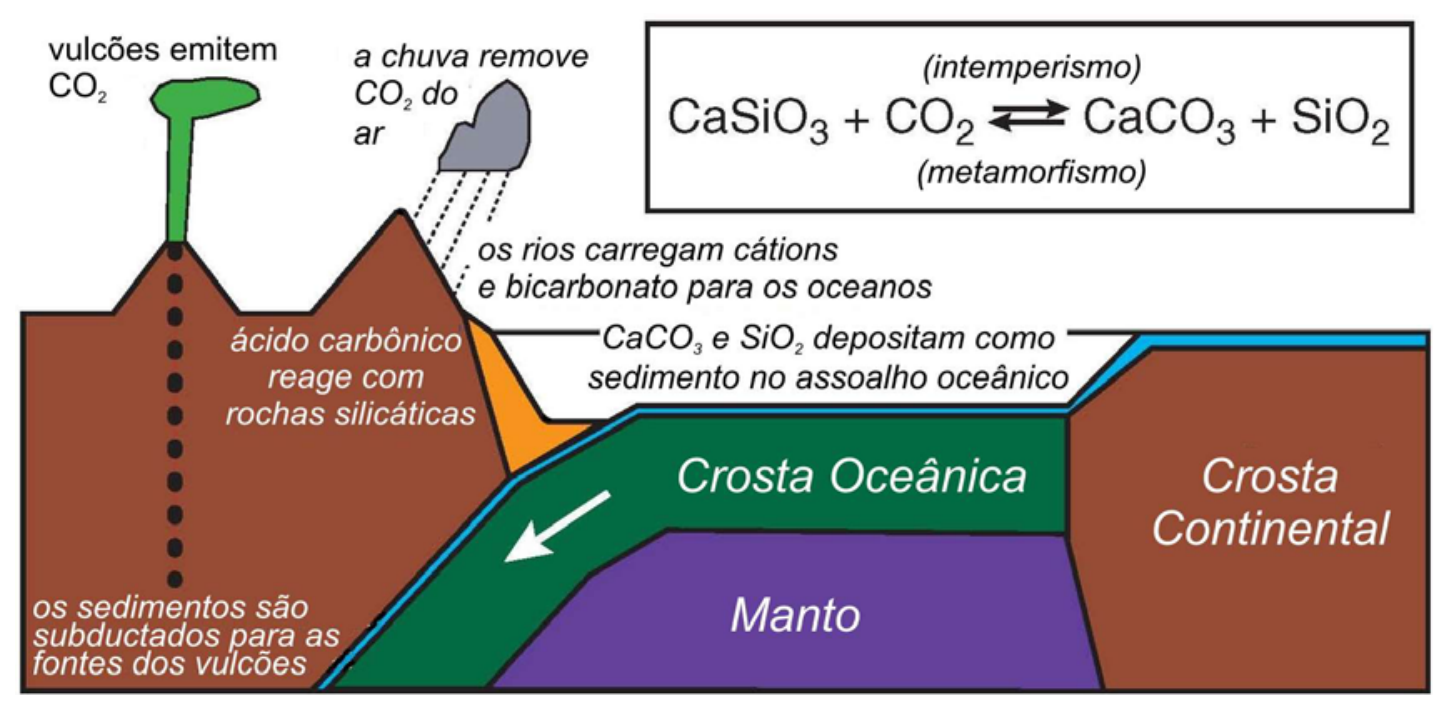

Figura 8. Ciclo do Carbono na Terra. $\mathrm{O}$ carbono fornecido à atmosfera e aos oceanos é proveniente das emanações vulcânicas na forma de dióxido de carbono, contendo cerca de $1 \%$ de ${ }^{13} \mathrm{C}$ e $99 \%$ de ${ }^{12} \mathrm{C}$. Se a remoção do carbono dos oceanos ocorresse apenas pelo soterramento de carbonato, esta razão isotópica seria mantida. Porém, o carbono também é removido na forma de matéria orgânica, tecido mole de algas e bactérias viventes na água do mar, que fracionam esta razão isotópica, sendo empobrecida cerca de $2,5 \%$ em ${ }^{13} \mathrm{C}$ (Hoffman \& Schrag, 1999).

\subsubsection{Ambiente Marinho}

Admitindo-se a introdução de ${ }^{13} \mathrm{C} /{ }^{12} \mathrm{C}$ constante nos oceanos, as variações seculares nas razões isotópicas poderiam ser atribuídas à variação na taxa de soterramento do $\mathrm{C}$ do carbonato e da matéria orgânica (Karthur, 1993). Ou seja, condições de nível do mar baixo, intensa circulação oceânica e oxigenação de águas profundas não favoreceriam a deposição de matéria orgânica, concentrando ${ }^{12} \mathrm{C}$ na água e precipitando carbonatos com $\delta^{13} \mathrm{C}$ negativo. Em condições de mar alto, a matéria orgânica é soterrada, enriquecendo a água do mar em ${ }^{13} \mathrm{C}$, resultando em carbonatos com $\delta^{13} \mathrm{C}$ positivo.

Segundo estudo realizado em plataforma atual por Broecker \& Peng (1982), a razão ${ }^{13} \mathrm{C} /{ }^{12} \mathrm{C}$ do mar pode variar com a profundidade, devido à fotossíntese ser restrita à zona fótica, enquanto que a oxidação da matéria orgânica produzida pela fotossíntese ocorre através da coluna d'água. O resultado é numa diminuição gradual do $\delta^{13} \mathrm{C}$ com o aumento da profundidade, registrado pelos carbonatos depositados ao longo da plataforma. Isso leva a considerar que o tempo de residência do $\mathrm{C}$ na água do mar $\left(8 \times 10^{4}\right.$ anos $)$ possa ser insuficiente para a homogeneização isotópica (Kaufman \& Knoll, 1995), diferindo o $\delta^{13} \mathrm{C}$ de carbonatos 
depositados na zona de mistura (águas rasas) e abaixo dela (águas mais profundas), ou seja, em águas estratificadas.

\subsubsection{Ambiente Restrito}

Em ambientes restritos, os valores de $\delta^{13} \mathrm{C}$ têm uma distribuição heterogênea e aleatória ao longo das seções estratigráficas, variando de forma independente, devido a fatores diversos, como acúmulo localizado de matéria orgânica ou sua decomposição metanogênica em ambiente anóxido durante a precipitação, enriquecendo a água em ${ }^{13} \mathrm{C}$ (Thunell et al., 1987)

\subsubsection{Carbonatos Neoproterozóicos}

Em seqüências carbonáticas neoproterozóicas não se identificou nenhuma variação dos valores de $\delta^{13} \mathrm{C}$ em função das fácies carbonáticas (mar raso ou profundo), mesmo ao longo de centenas de kilômetros, levando ao pressuposto de que os carbonatos neoproterozóicos teriam se depositado em condições de intensa mistura oceânica (Kaufman \& Knoll, 1995). A possibilidade de precipitação orgânica por secreção metabólica de conchas com razões isotópicas de C diferentes da água do mar parece influenciar a partir do Cambriano, já que carbonatos neoproterozóicos são, na quase totalidade, não esqueletais (Grant, 1992; Knoll \& Sweet, 1990). Assim, vários autores propõem uma curva de variação temporal do $\delta^{13} \mathrm{C}$, sintetizada por Halverson et al (2005) na Figura 9.

\subsubsection{Fracionamento isotópico do $\mathrm{O}$}

Dentre os mecanismos responsáveis pela composição isotópica de $\mathrm{O}$ na água do mar, estão a temperatura, glaciações, salinidade e padrão de circulação oceânica, conforme apresentados a seguir.

\subsubsection{Temperatura}

A temperatura influencia diretamente na incorporação de isótopos de oxigênio no retículo cristalino da calcita, seja em carbonatos orgânicos ou inorgânicos. $\mathrm{O}$ aumento de temperatura leva a uma maior incorporação de ${ }^{16} \mathrm{O}$ (oxigênio leve), enquanto que a diminuição da temperatura resulta na incorporação preferencial de ${ }^{18} \mathrm{O}$ (oxigênio pesado) no retículo. Alguns autores notaram que quanto mais antigo o carbonato, mais negativos são os valores de $\delta^{18} \mathrm{O}$ 
(Veizer et al., 1980; Burdett et al., 1990), levando à hipótese de que os oceanos antigos seriam empobrecidos em ${ }^{18} \mathrm{O}$, ou que a temperatura destes oceanos seria maior.

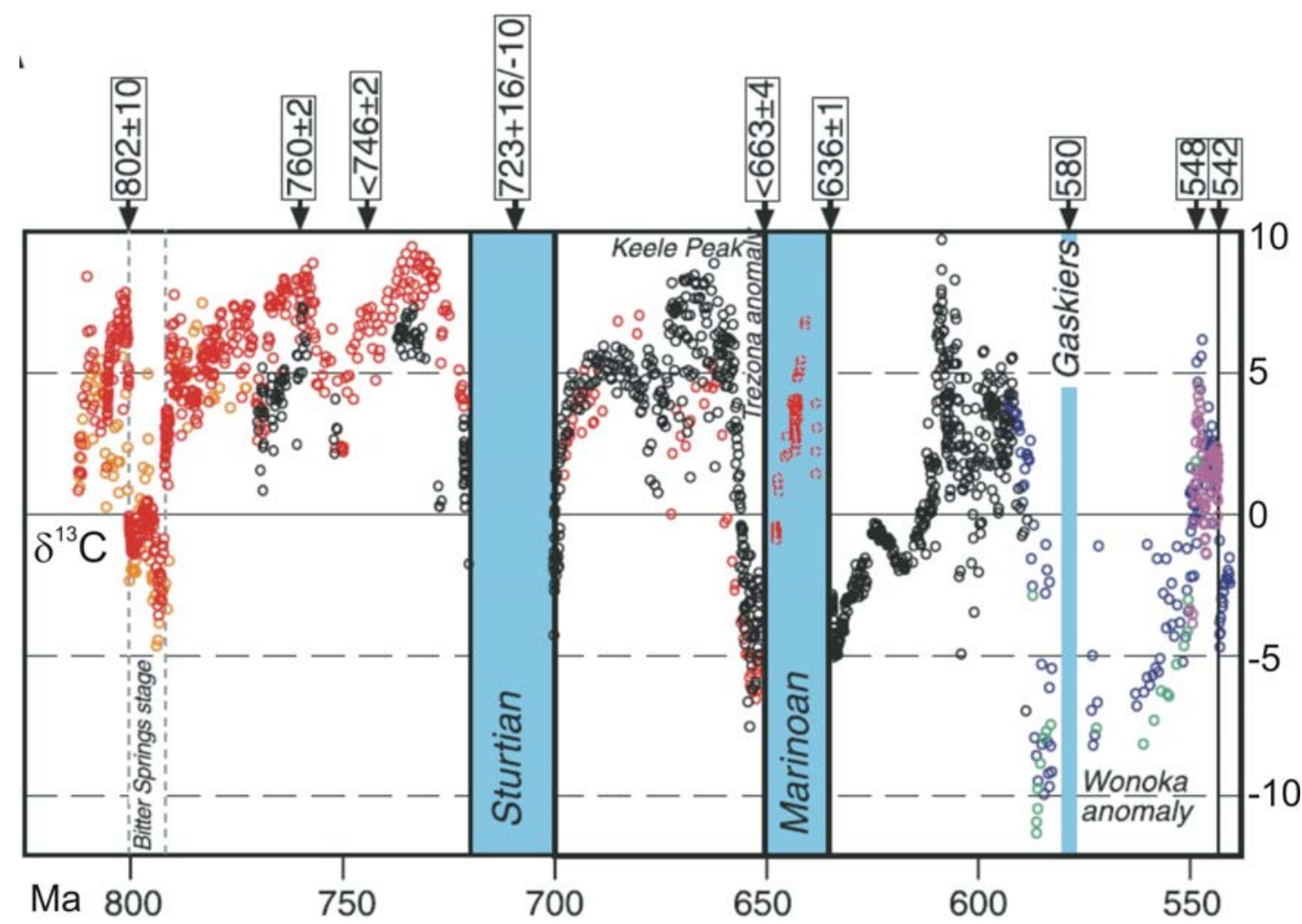

Figura 9. Curva de variação global de $\delta^{13} \mathrm{C}$ através do tempo, proposta por Halverson et al. (2005) para o Neoproterozóico, com as idades obtidas recentemente por diversos pesquisadores marcadas acima em Ma.

\subsubsection{Glaciação e Deglaciação}

As calotas de gelo polares se formam pela precipitação de águas originárias da evaporação em baixas latitudes. Neste processo, o vapor é enriquecido em ${ }^{16} \mathrm{O}$ fazendo com que a água oceânica seja enriquecida em ${ }^{18} \mathrm{O}$. Assim, os carbonatos precipitados em períodos glaciais possuem valores $\delta^{18} \mathrm{O}$ tendendo a positivo (Corfield, 1994), enquanto que em períodos de deglaciação os valores $\delta^{18} \mathrm{O}$ são mais negativos. No entanto, acredita-se que o degelo em si influenciaria menos as razões ${ }^{18} \mathrm{O} /{ }^{16} \mathrm{O}$ que o aquecimento da água em períodos pós-glaciais, não se sabendo ao certo qual fator exerceria maior controle, se a temperatura da água ou o derretimento/congelamento das calotas (Mallinson \& Compton, 1997). 


\subsubsection{Salinidade}

Como um dos principais processos responsáveis pelo aumento da salinidade é a evaporação, que remove ${ }^{16} \mathrm{O}$ da água do mar, então, quanto maior a salinidade da água, maior o valor de $\delta^{18} \mathrm{O}$ (Allan \& Matthews, 1982). Thunell et al. (1987) observaram que em zonas litorâneas os valores de $\delta^{18} \mathrm{O}$ são mais negativos, devido à diluição com água doce, enquanto que em bacias restritas, os valores $\delta^{18} \mathrm{O}$ são mais positivos, devido à evaporação.

\subsubsection{Diagênese}

Uma diagênese intensa pode influenciar os valores de $\delta^{18} \mathrm{O}$, de forma que esses valores reflitam a temperatura de soterramento e a troca com fluídos meteóricos e hidrotermais, com maior incorporação de ${ }^{16} \mathrm{O}$ quanto mais alta for a temperatura, modificando as razões ${ }^{18} \mathrm{O} /{ }^{16} \mathrm{O}$ originais. Assim, os valores mais negativos de $\delta^{18} \mathrm{O}$ de carbonatos antigos podem estar relacionados ao profundo soterramento que sofreram, conforme demonstrou Tucker (1986) que estudou carbonatos proterozóicos, com valores $\delta^{18} \mathrm{O}$ mais negativos que $-10 \%$, compostos inicialmente de aragonita, transformada em calcita pelo soterramento. Em função disto, alguns autores não utilizam os valores de $\delta^{18} \mathrm{O}$ para quimioestratigrafia, mas sim com um indicador sensível de alteração diagenética e térmica (Tucker, 1986; Brasier et al., 1992; Kaufman \& Knoll, 1995). Neste caso, os valores muito negativos (inferiores a - 11\%o) indicariam alteração diagenética a ponto de modificar as razões isotópicas de C e Sr (Brasier et al., 1992; Kaufman \& Knoll, 1995).

\subsection{ISÓTOPOS DE Sr}

O elemento ${ }^{87} \mathrm{Rb}$ contido nas rochas transforma-se no elemento ${ }^{87} \mathrm{Sr}$ por decaimento beta. Tais rochas ao serem alteradas intempericamente liberam, dentre outros elementos, o Sr nelas contido, com sua respectiva composição isotópica, para o ciclo hidrológico (Faure, 1986). As razões isotópicas ${ }^{87} \mathrm{Sr} /{ }^{86} \mathrm{Sr}$ são então homogeneizadas no oceano, seu reservatório final, isso porque o tempo de residência do Sr na água do mar é de $4 \mathrm{Ma}$, enquanto que o tempo de homogeneização inter-oceânica é de 1500 anos (Broecker \& Peng, 1982; Elderfield \& Greaves, 1982). As rochas depositadas nestes oceanos adquirem a composição isotópica destas águas no momento da deposição, que pode ser, posteriormente, mensurada e utilizada na quimioestratigrafia isotópica. 


\subsubsection{Mecanismos Geológicos}

Vários são os mecanismos geológicos que podem influenciar a razão ${ }^{87} \mathrm{Sr} /{ }^{86} \mathrm{Sr}$ da água do mar e que devem ser levados em consideração no estudo isotópico, dentre os principais estão a circulação hidrotermal das cordilheiras oceânicas, soerguimento tectônico, alterações na conFiguração dos continentes, mudanças no clima, variações no nível do mar, diagênese dos sedimentos no assoalho oceânico, alterações no padrão de circulação oceânica e impactos de meteoros.

\subsubsection{Atividade hidrotermal das cadeias meso-oceânicas}

A atividade hidrotermal das cadeias meso-oceânicas é conduzida pela mudança nas razões de espalhamento do assoalho oceânico. Acréscimos temporais deste espalhamento aumentarão também a atividade hidrotermal submarina, com baixa razão ${ }^{87} \mathrm{Sr} /{ }^{86} \mathrm{Sr}$, proveniente do manto (Banner, 2004). Ou seja, é possível observar que durante a construção de crosta oceânica ao longo da história da Terra resulta em longos períodos com razões ${ }^{87} \mathrm{Sr} /{ }^{86} \mathrm{Sr}$ notavelmente baixas, registrados nos carbonatos marinhos (Jones et al., 1994).

\subsubsection{Processos orogênicos e configurações paleogeográficas}

Outro mecanismo responsável pelas mudanças na razão ${ }^{87} \mathrm{Sr} /{ }^{86} \mathrm{Sr}$ é a orogênese e seus múltiplos efeitos, como (i) o aumento nas taxas de intemperismo físico-químico de rochas exumadas com alta razão ${ }^{87} \mathrm{Sr} /{ }^{86} \mathrm{Sr}$, (ii) a alteração dos padrões climáticos por efeitos orográficos e (iii) o metamorfismo e seus fluídos (Banner, 2004). Variações na origem e na idade destas rochas expostas influenciam a razão ${ }^{87} \mathrm{Sr} /{ }^{86} \mathrm{Sr}$ contida nas águas fluviais despejadas nos oceanos.

\subsubsection{Mudanças climáticas}

As variações climáticas, especialmente em ciclos glaciais, têm grande influência nas razões de intemperismo físico-químico sobre os continentes. Durante ciclos de flutuações entre períodos glaciais e interglaciais, tem-se um aumento do intemperismo como resultado das novas superfícies rochosas expostas, vales de vertentes íngremes, compensação isostática e flutuação das chuvas (Banner, 2004). Flutuações climáticas em períodos não glaciais também podem afetar as razões ${ }^{87} \mathrm{Sr} /{ }^{86} \mathrm{Sr}$ dos rios e dos aqüíferos (Banner et al. 1996) e, por conseqüência, do oceano. 


\subsubsection{Diagênese}

A diagênese pode variar as razões de ${ }^{87} \mathrm{Sr} /{ }^{86} \mathrm{Sr}$ através do tempo como função da extensão areal, taxas de deposição e tipo de sedimento marinho (Baker et al., 1982). Os sedimentos carbonáticos depositados nos oceanos têm uma composição isotópica semelhante à da coluna d'água e, por isso, o fluxo diagenético de Sr tende a manter as razões isotópicas ao longo do tempo, observando-se apenas um monótono acréscimo devido à geração de ${ }^{87} \mathrm{Sr}$, radiogênico, através do decaimento de ${ }^{87} \mathrm{Rb}$ presente nas rochas da crosta terrestre. No entanto, se a diagênese introduzir novos átomos de Sr não marinho dentro da estrutura do mineral, as razões ${ }^{87} \mathrm{Sr} /{ }^{86} \mathrm{Sr}$ originais podem ser alteradas.

\subsubsection{Mudanças no nível do mar}

O rebaixamento do nível do mar expõe interiores cratônicos e sedimentos siliciclásticos e carbonáticos da margem continental a fluídos meteóricos quimicamente mais agressivos. $\mathrm{O}$ aumento do intemperismo destas fontes leva $\mathrm{Sr}$ com razão ${ }^{87} \mathrm{Sr} /{ }^{86} \mathrm{Sr}$ relativamente alta para os oceanos (Banner, 2004). Desta forma é possível observar uma correlação inversa entre o nível do mar e as razões ${ }^{87} \mathrm{Sr} /{ }^{86} \mathrm{Sr}$ (Pursell \& Banner, 1997).

\subsubsection{Comutação entre os modos de circulação oceânica}

Mudanças na circulação termohalina dos oceanos, de homogeneizada à estratificada, pode provocar ou serem provocadas por mudanças climáticas (Wilde \& Berry, 1984; Knoll et al., 1996). Estas mudanças podem ser observadas em seqüências de água rasa antigas, bem preservadas, comparando-se suas variações lito-faciológicas com as respectivas razões ${ }^{87} \mathrm{Sr} /{ }^{86} \mathrm{Sr}$.

\subsubsection{Eventos geológicos instantâneos}

Impactos de meteoros podem ter efeitos sobre o clima global, contribuindo para o aumento, em curto prazo, das razões ${ }^{87} \mathrm{Sr} /{ }^{86} \mathrm{Sr}$ na água do mar, pois o aquecimento do nitrogênio atmosférico por choque leva a um dramático aumento na chuva ácida $\left(\mathrm{HNO}_{3}\right)$ e conseqüente intemperismo continental (Martin \& McDougall, 1991).

Vários dos processos discutidos acima influenciam a razão ${ }^{87} \mathrm{Sr} /{ }^{86} \mathrm{Sr}$ dos oceanos de diferentes maneiras e, geralmente, operam de forma integrada no Sistema Terra. Ainda é difícil a determinação dos efeitos relativos de cada processo sobre a razão ${ }^{87} \mathrm{Sr} /{ }^{86} \mathrm{Sr}$ quando eles atuam conjuntamente em determinado espaço de tempo. Por exemplo, um aumento significativo do 
vulcanismo mantélico nas cadeias meso-oceanicas, com baixas razões ${ }^{87} \mathrm{Sr} /{ }^{86} \mathrm{Sr}$, influenciaria a diminuição da razão isotópica de $\mathrm{Sr}$ dos oceanos. Por outro lado, o $\mathrm{CO}_{2}$ liberado pelo mesmo vulcanismo para a atmosfera, adicionaria indiretamente altas razões ${ }^{87} \mathrm{Sr} /{ }^{86} \mathrm{Sr}$ nos oceanos, devido ao conseqüente aquecimento global que aceleraria o ciclo hidrológico, aumentando o intemperismo das rochas continentais, que possuem altas razões isotópicas de Sr. Em seguida, o intenso intemperismo removeria o $\mathrm{CO}_{2}$ da atmosfera e provocaria o resfriamento global, podendo levar à condições glaciais, cessando o intemperismo. Com o fim do período glacial, o intemperismo seria ainda mais intenso, devido ao aumento das superfícies expostas, o que aumentaria as razões ${ }^{87} \mathrm{Sr} /{ }^{86} \mathrm{Sr}$ levada aos oceanos (Banner, 2004).

\subsubsection{Quimioestratigrafia Isotópica de Sr}

Após uma breve descrição e compreensão do comportamento das razões isotópicas de $\mathrm{Sr}$ frente aos diversos processos geológicos, é válido salientar que os isótopos de Sr têm uma especial aplicabilidade na quimioestratigrafia por dois motivos principais: (i) seu longo tempo de residência oceânica em relação ao tempo de mistura, que propicia alto grau de homogeneização entre os oceanos, e (ii) pelo fato dos efeitos de fracionamento isotópico serem desprezíveis através do tempo (Banner, 2004). Estas características fundamentais produzem valores ${ }^{87} \mathrm{Sr} /{ }^{86} \mathrm{Sr}$ idênticos em todas as amostras de precipitados marinhos autigênicos depositados na mesma época (Faure, 1986). Como a variação desta razão nos mares é regida apenas pelos processos geológicos ao longo do tempo, então se torna possível construir uma curva de variação da razão ${ }^{87} \mathrm{Sr} /{ }^{86} \mathrm{Sr}$ ao longo do tempo geológico e utilizá-la na compreensão dos grandes eventos geológicos, na correlação estratigráfica de sedimentos de mar aberto e na datação relativa destes sedimentos.

Para o estabelecimento da correlação isotópica é fundamental o conhecimento da história sedimentar e conteúdo terrígeno da seqüência estudada, de forma a garantir que a razão isotópica original não tenha sido alterada posteriormente pelo decaimento de ${ }^{87} \mathrm{Rb}$ presente em minerais terrígenos ou percolação de fluídos pós-deposicionais. Estas alterações podem ser observadas através da aplicação de índices de alteração a ser melhor explicados no Capítulo 5 item 5.3. A correlação isotópica é melhor estabelecida em seqüências datadas radiometricamente ou intervalos calibrados bioestratigraficamente (McArthur, 1994). A curva de razões ${ }^{87} \mathrm{Sr} /{ }^{86} \mathrm{Sr}$ versus tempo vem sendo cada vez mais detalhada, conforme novos dados confiáveis de seqüências bem datadas têm sido gerados. 


\subsubsection{Carbonatos Neoproterozóicos}

Os dados isotópicos de $\mathrm{Sr}$ em carbonatos marinhos precambrianos ainda são esparsos em relação ao longo tempo geológico que suas seqüências representam (Melezhik et al., 2001), mas é bem possível que o crescente interesse nesta metodologia por parte de vários pesquisadores consiga refinar as curvas para este período, pois (i) este pode ser um critério importante na compreensão da evolução crustal (Banner, 2004), (ii) o Arqueano e o Proterozóico são períodos importantes na evolução da crosta, dos oceanos e da atmosfera terrestres (Kaufman et al., 1997), e (iii) a limitada biota destes períodos requer o uso da quimioestratigrafia como importante ferramenta na correlação de suas seqüências (Banner, 2004).

A curva temporal de ${ }^{87} \mathrm{Sr} /{ }^{86} \mathrm{Sr}$ para os carbonatos neoproterozóicos (Figura 10) pode ser dividida em duas partes: a mais jovem é melhor estabelecida e demonstra uma relativa elevação nas razões ${ }^{87} \mathrm{Sr} /{ }^{86} \mathrm{Sr}$ de 0,7066 em 590 Ma para 0,7085 na transição com o Cambriano, de acordo com a curva de Jacobsen \& Kaufman (1999); a mais antiga, ao contrário, possui razões mais baixas, mas demonstra que não há consenso entre os pesquisadores quanto às razões ${ }^{87} \mathrm{Sr} /{ }^{86} \mathrm{Sr}$ em carbonatos depositados entre 850 e 590 Ma (Melezhik et al., 2001).

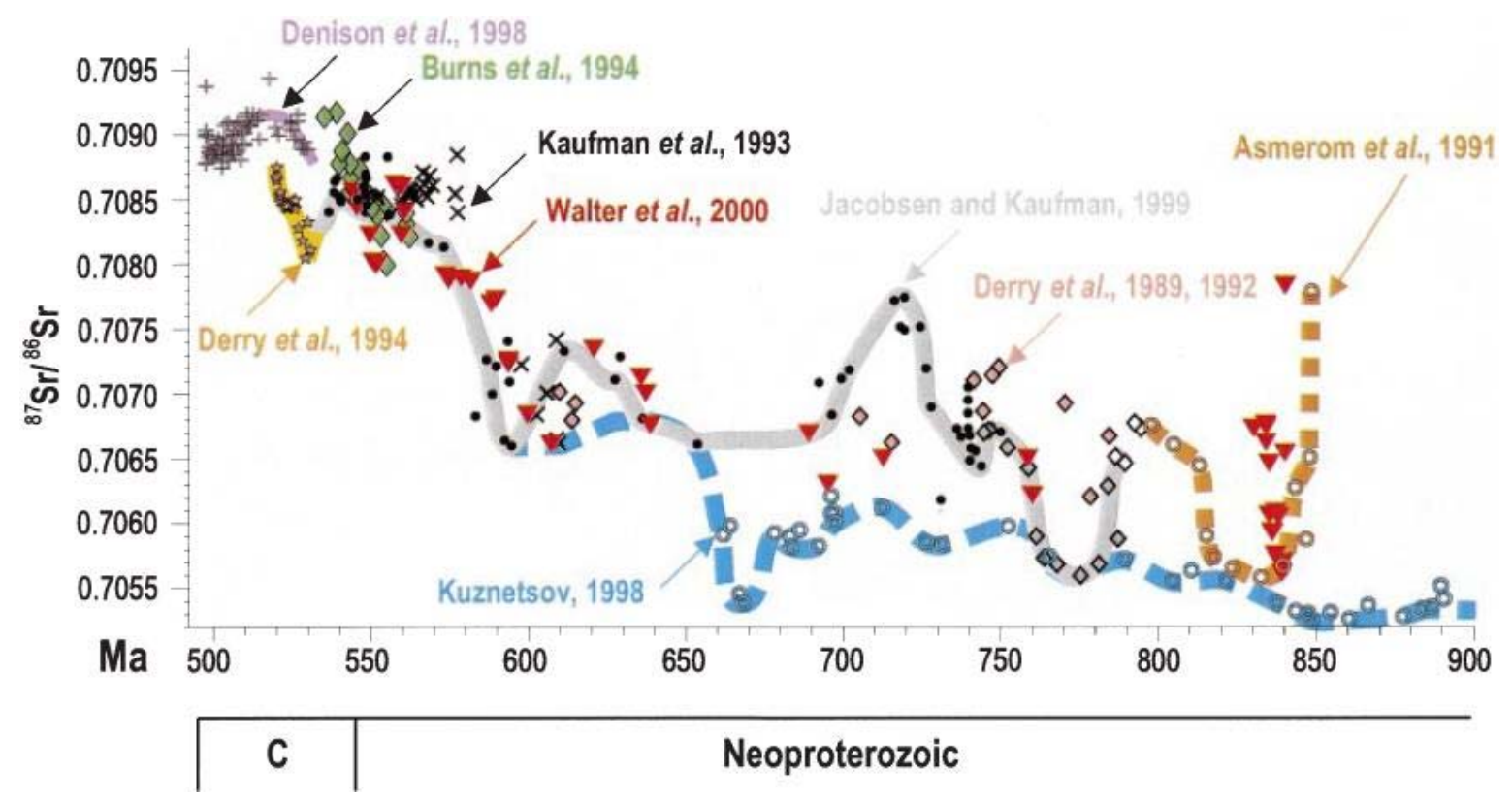

Figura 10. Curva temporal de ${ }^{87} \mathrm{Sr} /{ }^{86} \mathrm{Sr}$ para os carbonatos neoproterozóicos com as medições realizadas por diversos pesquisadores em várias formações geológicas, mostrando divergência entre 900 e 590 Ma (Melezhik et al., 2001).

\subsection{PROVENIÊNCIA DE SEDIMENTOS}

O elemento ${ }^{147} \mathrm{Sm}$ contido nas rochas se transforma no elemento ${ }^{143} \mathrm{Nd}$ por decaimento alfa. Estes elementos fazem parte dos Elementos Terras Raras (série Lantanídeos) e são 
altamente insolúveis em água, de maneira que as razões ${ }^{147} \mathrm{Sm} /{ }^{143} \mathrm{Nd}$ dos sedimentos gerados pela alteração das rochas são mantidas, podendo haver mistura de sedimentos provenientes de fontes diferentes. Assim, podem-se utilizar as razões ${ }^{147} \mathrm{Sm} /{ }^{143} \mathrm{Nd}$ em tais sedimentos para identificar suas fontes, através do cálculo de suas idades modelo $\left(\mathrm{T}_{\mathrm{DM}}\right) \mathrm{e}^{143} \mathrm{Nd} /{ }^{144} \mathrm{Nd}$.

\subsubsection{Idades Modelo Sm/Nd $\mathrm{T}_{\mathrm{DM}}$}

As idades $\mathrm{T}_{\mathrm{DM}}$ são baseadas em um modelo de manto empobrecido (Depleted Mantle) e determinadas graficamente utilizando-se as razões isotópicas obtidas na amostra, conforme proposto por DePaolo (1981). Estas idades $\mathrm{T}_{\mathrm{DM}}$ podem significar a idade de formação crustal de rochas arqueanas, fusão crustal ou uma mistura de materiais derivados do manto em diferentes épocas (Arndt \& Goldstein, 1987).

Os isótopos de Sm e Nd têm uma distribuição relativamente homogênea no manto, tendo suas razões isotópicas sido progressivamente modificadas apenas pelo decaimento do ${ }^{147} \mathrm{Sm}$ para o ${ }^{143} \mathrm{Nd}$. Durante uma fusão parcial, o $\mathrm{Nd}$ é enriquecido no fundido em relação ao $\mathrm{Sm}$, fazendo com que as rochas crustais tenham razões ${ }^{147} \mathrm{Sm} /{ }^{143} \mathrm{Nd}$ mais baixas que o manto (Faure, 1986). Conseqüentemente, o aumento da razão ${ }^{143} \mathrm{Nd} /{ }^{144} \mathrm{Nd}$ nas rochas crustais $\left(\varepsilon_{\mathrm{Nd}}\right.$ negativo) será menor que no manto ( $\varepsilon_{\mathrm{Nd}}$ positivo).

O modelo de DePaolo (1981) considera uma evolução do manto não linear através do tempo geológico, continuamente empobrecido em $\mathrm{Nd}$ e enriquecido em $\mathrm{Sm}$, conseqüentemente produzindo mais ${ }^{143} \mathrm{Nd}$. Assim, com as razões atuais ${ }^{147} \mathrm{Sm} /{ }^{143} \mathrm{Nd} \mathrm{e}{ }^{143} \mathrm{Nd} /{ }^{144} \mathrm{Nd}$ de uma amostra, pode-se calcular a razão ${ }^{143} \mathrm{Nd} /{ }^{144} \mathrm{Nd}$ inicial e o $\varepsilon_{\mathrm{Nd}}$ para uma determinada idade.

$$
\left({ }^{143} \mathrm{Nd} /{ }^{144} \mathrm{Nd}\right)_{\text {inicial }}=\left({ }^{143} \mathrm{Nd} /{ }^{144} \mathrm{Nd}\right)_{\text {amostra }}-\left({ }^{147} \mathrm{Sm} /{ }^{144} \mathrm{Nd}\right)_{\text {amostra }} \times\left(\mathrm{e}^{\lambda t}\right)
$$

onde $\lambda$ é a constante de desintegração do ${ }^{147} \mathrm{Sm}\left(6,54 \times 10^{-12}\right.$ anos $\left.{ }^{-1}\right)$ e té a idade calculada.

$$
\begin{aligned}
& \varepsilon_{\text {Nd }}(t)=\left[\left(\left(^{143} \mathrm{Nd} /{ }^{144} \mathrm{Nd}\right)_{\text {amostra }} /\left({ }^{143} \mathrm{Nd} /{ }^{144} \mathrm{Nd}\right)_{\mathrm{DM}(\text { (hoje })}-1\right] \times 10000\right. \\
& \text { onde a razão }{ }^{143} \mathrm{Nd} /{ }^{144} \mathrm{Nd} \text { DM hoje }(\text { do Depleted Mantle atual })=0,513114 \text {. }
\end{aligned}
$$

Em um gráfico (Figura 11), de $\varepsilon_{\mathrm{Nd}}$ versus a curva de evolução do manto empobrecido através do tempo, plota-se uma reta, cuja origem é o $\varepsilon_{\mathrm{Nd}}$ (ou a razão ${ }^{143} \mathrm{Nd} /{ }^{144} \mathrm{Nd}$ ), com inclinação em função da razão ${ }^{147} \mathrm{Sm} /{ }^{143} \mathrm{Nd}$. A intersecção desta reta com a curva de evolução do manto empobrecido (DM) fornece a idade modelo da rocha. 


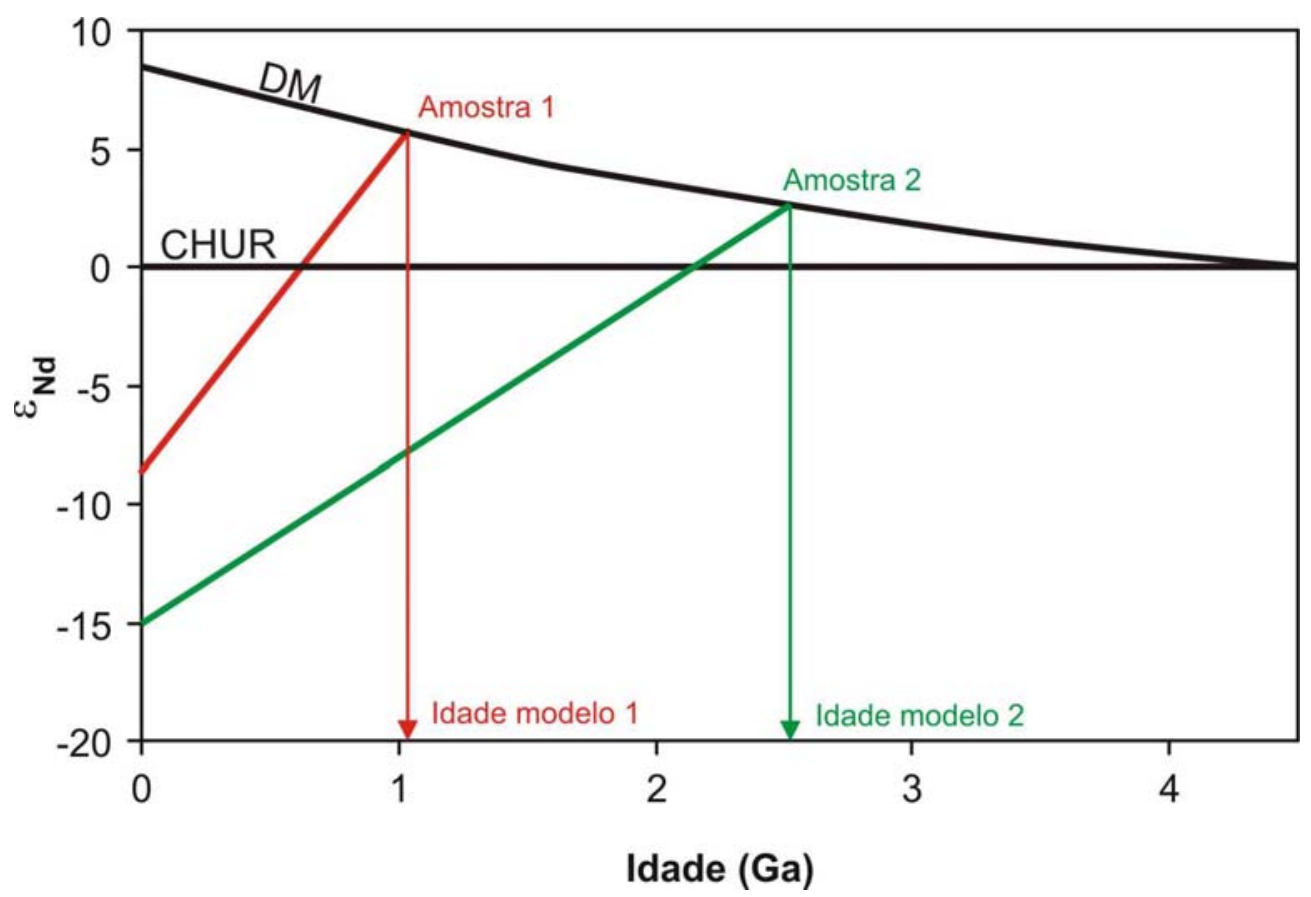

Figura 11. Representação de duas idades $\mathrm{T}_{\mathrm{DM}}$, onde as linhas pretas representam a evolução do manto não empobrecido (linha CHUR) e do manto empobrecido (curva DM) e as linhas coloridas a evolução isotópica de $\varepsilon_{\mathrm{Nd}}$ das rochas através do tempo.

\subsubsection{Proveniência}

Estudos sobre o comportamento de Elementos Terras Raras em águas naturais mostraram que ocorre fracionamento apenas durante sua dissolução (Elderfield \& Greaves, 1982). No entanto, $\mathrm{Sm}$ e $\mathrm{Nd}$ são altamente insolúveis em água, de forma que o intemperismo tem um efeito muito pequeno sobre as composições destes elementos em sedimentos clásticos, ao contrário dos sedimentos químicos, que parecem refletir os Elementos Terras Raras da água (Shaw \& Wasserburg, 1985). Assim, os sedimentos gerados pela alteração de determinada rocha mantêm as razões isotópicas originais desta, durante todo o processo de transporte e sedimentação. Numa bacia sedimentar, os sedimentos depositados guardarão as razões isotópicas de sua rocha-fonte, podendo ser utilizados no cálculo da idade $\mathrm{T}_{\mathrm{DM}}$ da fonte (Figura 12). Importante ressaltar que é comum uma bacia sedimentar ser alimentada por mais de uma fonte e, neste caso, ter razões isotópicas de $\mathrm{Sm}$ e $\mathrm{Nd}$ intermediárias, que corresponderão à mistura das diversas fontes. As idades adquiridas pela análise dos sedimentos, então, fornecem uma idade modelo da fonte, ou a mistura de fontes, mas sempre representam uma idade máxima de sedimentação (Figura 12). 


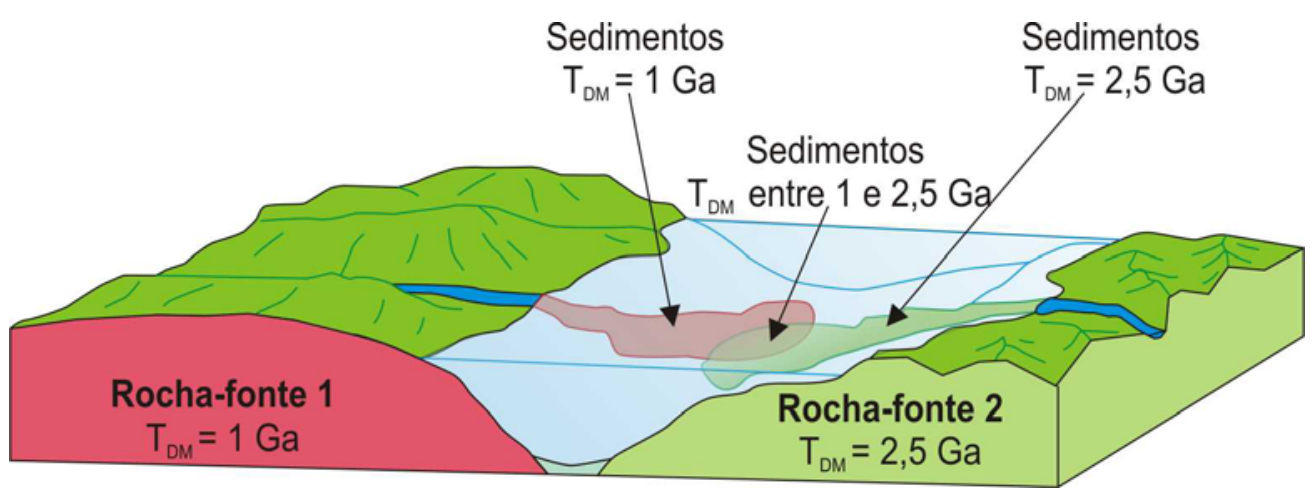

Figura 12. Bloco diagrama mostrando relação entre as idades $T_{D M}$ dos sedimentos, depositados numa bacia sedimentar qualquer, e de sua área-fonte (modificado de Kulerud, 2005). 


\section{CAPÍTULO 3 GEOLOGIA REGIONAL E LOCAL}

Neste capítulo serão apresentadas rapidamente a localização geográfica e vias de acesso das áreas selecionadas para o presente estudo. Com maior ênfase, pretende-se contextualizar a geologia regional e local, sem as descrições detalhadas das seções estratigráficas levantadas neste estudo, que o será feito no Capítulo V.

\subsection{LOCALIZAÇÃO}

As áreas de estudo localizam-se na porção centro-sul da meso-região do Estado de Mato Grosso, nos municípios de Nobres (próximo à cidade homônima) e Rosário Oeste, na região de Marzagão. A área situada próxima à cidade de Nobres dista cerca de $130 \mathrm{~km}$ da Capital Cuiabá, cujo acesso é realizado por via asfaltada pelas BR 163 e BR 364 (Figura 13) e estradas vicinais de leito natural existentes nos arredores de Nobres. A área situada na região de Marzagão dista cerca de $110 \mathrm{~km}$ de Cuiabá, cujo acesso é feito por via asfaltada através da MT 251, tomando-se então a estrada da Usina Hidrelétrica de Manso (Figura 13). A partir desta usina o acesso se dá pela via de leito natural MT 351. A partir de Marzagão, utilizaram-se diversas estradas vicinais.

\subsection{GEOLOGIA REGIONAL}

A Faixa Paraguai está geologicamente situada na borda sudeste do Craton Amazônico (Figura 14), composta de rochas sedimentares depositadas numa margem passiva durante o Neoproterozóico, posteriormente dobradas pela Orogênese Brasiliana/Pan-Africana. Estas rochas sedimentares são divididas em três unidades litoestratigráficas: Grupo Cuiabá, Grupo Araras e Grupo Alto Paraguai.

$\mathrm{Na}$ porção mais basal da Faixa Paraguai encontra-se o Grupo Cuiabá (Figura 15) formado, da base para o topo, por filitos ricos em matéria orgânica e metadolomitos, sobrepostos por metassedimentos glaciomarinhos e turbidíticos, como diamictitos, conglomerados, arenitos e folhelhos (Alvarenga \& Trompette, 1992). Esta seqüência grada lateralmente para as formações Bauxi e Puga (Figura 15). A Formação Bauxi é representada por diamictitos intercalados com camadas de siltitos, quartzitos e conglomerados, depositados sob influência glacial. A Formação 
Puga é composta principalmente de diamictitos depositados na área cratônica e correlacionados à glaciação Marinoana (Nogueira, 2003; Alvarenga et al., 2004; Trindade et al., 2004).

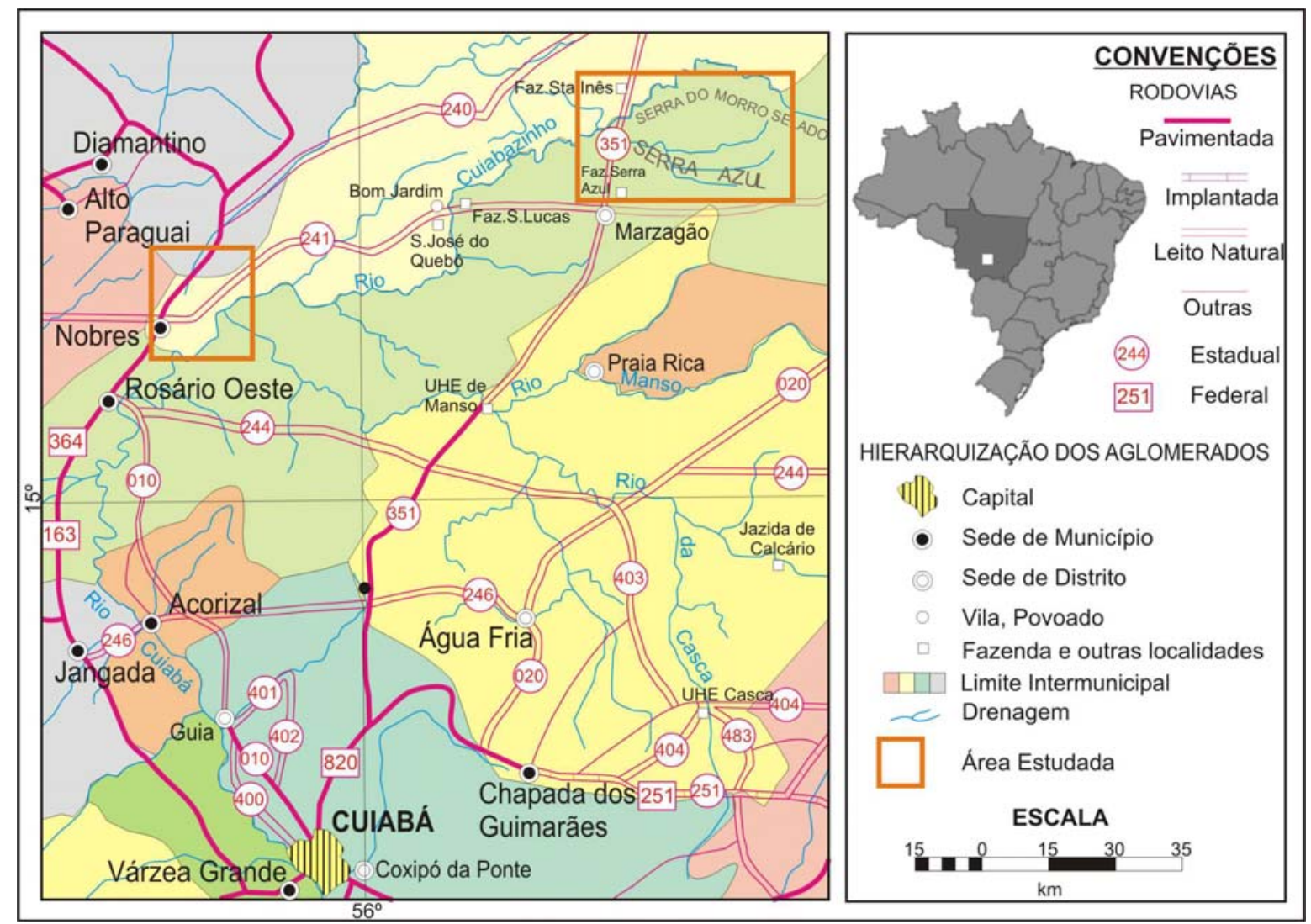

Figura 13. Mapa de localização indicando as áreas de estudo e vias de acesso (modificado do Mapa Político, Rodoviário e Estatístico de Mato Grosso, edição 2000).

Estas rochas formadas sob a influência da glaciação Marinoana são capeadas por cerca de $1300 \mathrm{~m}$ de carbonatos do Grupo Araras, que foi dividido em duas formações por Almeida (1964): Formação Guia, composta de aproximadamente $250 \mathrm{~m}$ de calcário e calcário argiloso laminados, sobreposta pela Formação Nobres com cerca de 1100 m de dolomitos depositados em ambiente de plataforma rasa.

Sobreposta ao Grupo Araras, foi encontrada, durante o desenvolvimento deste trabalho, a Formação Serra Azul (Figueiredo et al., 2005; Alvarenga et al., submetido). Esta formação é composta essencialmente por cerca de $70 \mathrm{~m}$ de diamictito glacial maciço na porção mais basal, recoberto por aproximadamente $200 \mathrm{~m}$ laminitos (Figueiredo et al., 2004). No topo ocorrem camadas de calcário num intervalo de $12 \mathrm{~m}$, acima do qual observa-se um aumento da quantidade e da espessura de camadas de arenito fino intercaladas, em direção à Formação Raizama. 


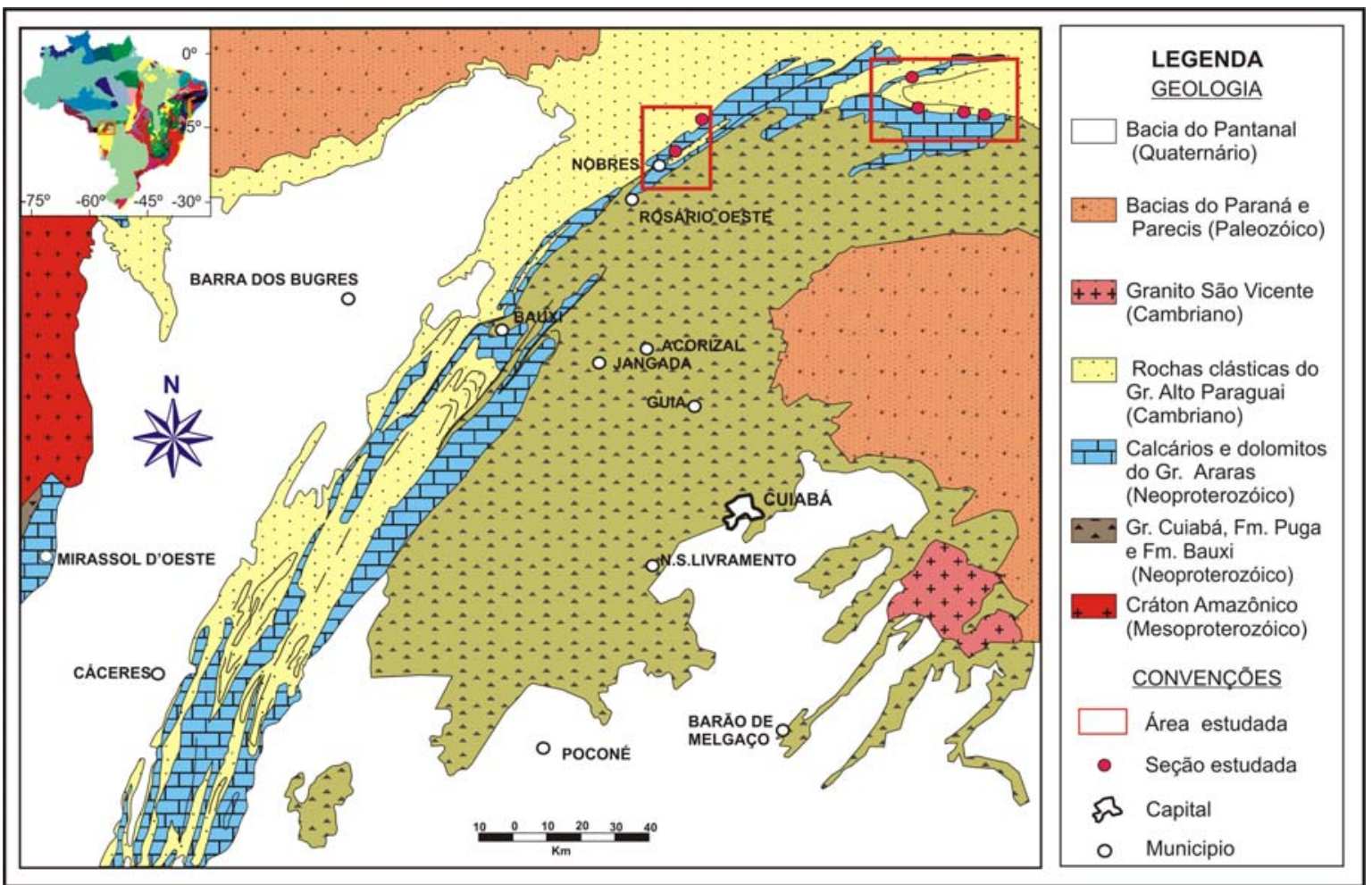

Figura 14. Mapa geológico regional da Faixa Paraguai em Mato Grosso (modificado de Alvarenga, 1988), com as áreas selecionadas para estudo e as seções detalhadas.

A unidade superior da faixa consiste das rochas siliciclásticas do Grupo Alto Paraguai (Figura 15), dividido em duas formações geológicas: Formação Raizama e Formação Diamantino. A Formação Raizama é composta de conglomerados, arcóseos e arenitos, depositados em águas epineríticas, pouco profundas, e ambiente dominado por marés, durante subsidência lenta e contínua (Almeida, 1964). A Formação Diamantino é composta de folhelhos vermelhos, siltitos e arcóseos, depositados durante o soerguimento de porções mais a sudeste, que gerou uma bacia sucessora com influência marinha e continental tipo molassa (Hennies, 1966).

\subsection{GEOLOGIA LOCAL}

A área selecionada para este estudo localiza-se na porção norte da Faixa Paraguai, Estado de Mato Grosso, municípios de Nobres e Rosário Oeste, estruturalmente situada na Zona Externa, não metamorfisada. Trabalhos de campo que foram realizados anteriormente em parte da área por Ganzer e Figueiredo (2004) e Santos e Coelho (2004), ora confirmavam a literatura existente, ora demonstravam situações novas que necessitavam de um estudo mais detalhado. 
Aqui se mantém a denominação Grupo Araras de Almeida (1964), dividido em duas formações (Hennies, 1966): Guia, composta predominantemente de calcários, e Nobres, constituída predominantemente de dolomitos. Optou-se por esta divisão pela facilidade de seu uso em campo, ao contrário daquela proposta por Nogueira (2003), um pouco mais complexa, o qual divide o Grupo Araras, da base para o topo, em quatro formações: Mirassol d'Oeste (dolomito de capa), Guia (calcários), Serra do Quilombo (brechas dolomíticas) e Nobres (dolomitos e arenitos).

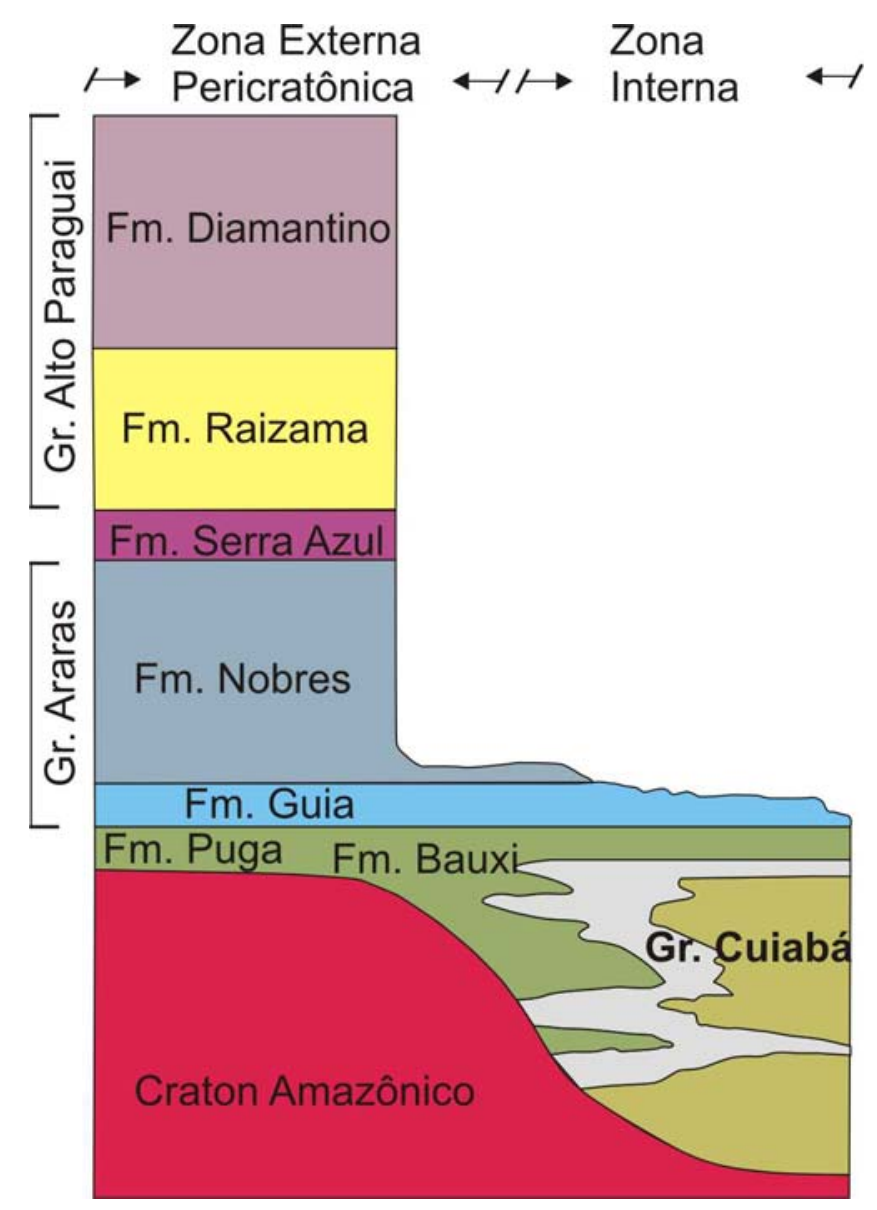

Figura 15. Coluna estratigráfica esquemática da Faixa Paraguai no Estado de Mato Grosso (modificado de Alvarenga, 1988).

$\mathrm{Na}$ área de estudo encontra-se toda a seqüência da Faixa Paraguai, desde sua base formada pelo Grupo Cuiabá até sua seqüência de topo, a Formação Diamantino. Porém, como o objeto de estudo deste trabalho se refere apenas aos carbonatos do Grupo Araras e à Formação Serra Azul (Figueiredo et al., 2004; Alvarenga et al., submetido), a descrição das seções a seguir se aterá a eles. As camadas encontram-se subverticalizadas na região de Nobres, enquanto que na região de Marzagão (município de Rosário Oeste) as camadas mergulham cerca de $15^{\circ}$ no flanco sul da Sinclinal Serra Azul e são verticais no flanco norte da mesma sinclinal. 


\subsubsection{Grupo Araras}

O Grupo Araras é constituído predominantemente de carbonatos, estando sobreposto aos diamictitos glaciais da Formação Puga e sotoposto aos diamictitos, também glaciais, da Formação Serra Azul. Este grupo encontra-se amplamente distribuído na região, com boas exposições esparsas devido ao clima subtropical reinante na região, que gera espessos mantos de alteração e terrenos cársticos. Seus melhores afloramentos constam de pedreiras, cortes de estrada, serras escarpadas e dolinas de abatimento recente. Este grupo é dividido em duas unidades carbonáticas (Figura 15), Formação Guia e Formação Nobres (Almeida, 1964).

\subsubsection{Formação Guia}

A Formação Guia constitui a porção inferior do Grupo Araras, de composição predominantemente pelítica-calcárea (Almeida, 1964; Hennies, 1966; Alvarenga, 1990). Esta formação encontra-se sobreposta aos diamictitos da Formação Puga, em contato brusco tipo lobos de sobrecarga (Nogueira et al., 2003), e sotoposta aos dolomitos da Formação Nobres.

Sua deposição se inicia com cerca de $20 \mathrm{~m}$ de dolomito róseo (Alvarenga, 1990) com presença de estromatólitos estratiformes e raramente dômicos (Nogueira, 2003), não exposto na Província Serrana devido aos depósitos de talus que o recobrem. Estes dolomitos passam bruscamente a calcários maciços ou apresentando laminação, ritmicidade, lâminas de argila, ocorrência de margas e de folhelhos intercalados (Nogueira, 2003; Ganzer e Figueiredo, 2004). Estas litofácies refletem uma plataforma moderadamente profunda a profunda (Nogueira, 2003).

\subsubsection{Formação Nobres}

A Formação Nobres constitui a porção superior do Grupo Araras, de composição predominantemente dolomítica (Almeida, 1964; Hennies, 1966; Alvarenga, 1990), e está sobreposta aos calcários da Formação Guia e sotoposta aos diamictitos da Formação Serra Azul.

Esta unidade inicia-se com a deposição de dolomito maciço a laminado, passando a brecha dolomítica cimentada por calcita, dolomito com laminações produzidas por ondas, estratificação hummocky com terrígenos, brechas dolomíticas com matriz, oólitos, estromatólitos dômicos e estratiforme, camada de arcóseo, dolomitos parcialmente a completamente silicificados, pelitos laminados e estromatólitos colunares (Nogueira, 2003; Ganzer e Figueiredo, 2004). Segundo Nogueira (2003), tais litofácies refletem uma plataforma saturada em carbonato e influenciada por sismos na base, posteriormente dominada por tempestades, passando a uma planície de maré no topo. 


\subsubsection{Formação Serra Azul}

Esta formação constitui uma nova unidade litoestratigráfica que foi descoberta e mapeada, durante este trabalho, através do levantamento de 5 seções estratigráficas, sendo 3 ao longo da Serra Azul (seções 4, 5 e 6), 1 na Serra do Morro Selado (seção 7) e 1 na região de Nobres (seção 8). A mesma foi estabelecida com base no Código Brasileiro de Nomenclatura Estratigráfica (Petri, 1987), obedecendo os critérios de uniformidade litológica, continuidade e mapeabilidade. Para a seleção do nome, utilizou-se o termo geográfico de uma feição natural, a Serra Azul, bem estabelecido na região. A localização exata de seu estratótipo consta de um perfil (seção 4) entre os pontos UTM 0660714E/8388096N e 0660374E/8388741N, flanco sul da Sinclinal Serra Azul de eixo E-W, porção norte da Faixa Paraguai (Figueiredo et al., 2005a).

A Formação Serra Azul, com espessura total de 250 a 300 m, sobrepõe os dolomitos da Formação Nobres e sotopõe os conglomerados e arenitos da Formação Raizama. Sua exposição é restrita por geralmente estar coberta por depósitos de talus recentes dos arenitos da Formação Raizama, que sustentam as serras dessa região. Os melhores afloramentos encontram-se em corte de estrada, no interior de ravinas e cavas de mineração. É possível dividir a Formação Serra Azul informalmente em duas unidades para uma melhor análise litoestratigráfica: unidade A, diamictitos basais, e unidade B, laminitos superiores (Figura 16).

\subsubsection{Unidade A}

Esta unidade possui uma espessura em torno de $70 \mathrm{~m}$ e está depositada sobre a Formação Nobres (Figura 16), no entanto seu contato basal não foi observado. É constituída basicamente de diamictito maciço a pobremente estratificado, com abundante matriz silto-argilosa vermelha contendo clastos variegados na composição, tamanho e forma, dispersos na matriz. Os clastos variam em tamanho de seixos a blocos e em forma de angulosos a arredondados, ocasionalmente facetados, polidos ou estriados (Figura 16). Sua composição também é diversa, constando de carbonatos, cherts, quartzo, arenitos, quartzitos, rochas graníticas, máficas e metamórficas. Embora seu contato basal não esteja exposto, a presença de fragmentos de carbonatos e chert pode supor que seja erosivo. O contato superior com a Unidade B se dá de forma concordante e brusca. 


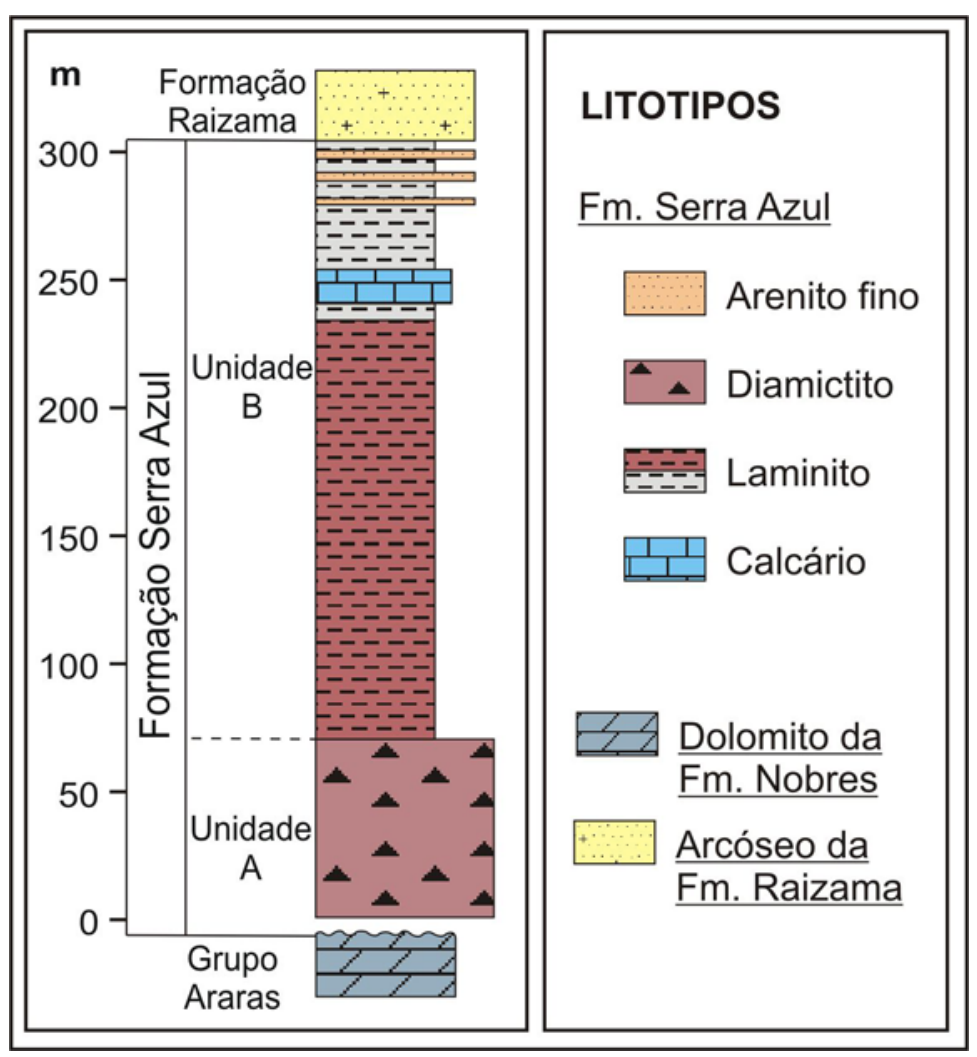

Figura 16. Coluna estratigráfica da Formação Serra Azul, compartimentada informalmente em duas unidades litológicas: diamictitos de origem glacial (Unidade A) e laminitos gerados pelo degelo (Unidade B), com deposição de carbonato e terrígenos no topo.

\subsubsection{Unidade B}

Sobreposta à Unidade A ocorre uma fina e persistente camada de $60 \mathrm{~cm}$ de laminito síltico amarelo com alguns grânulos (Figura 16), na maioria compostos de quartzo e chert arredondados. Esta camada é recoberta por cerca de $200 \mathrm{~m}$ de laminito síltico vermelho, com esparsos grânulos, que grada, em direção ao topo, para laminito argiloso cinza, onde podem ser encontradas camadas de carbonato intercaladas em alguns locais. No topo se observam intercalações de camadas de espessuras decimétricas de arenito muito fino, que se tornam cada vez mais freqüentes e mais espessas em direção ao topo. O contato de topo com os conglomerados e arcóseos da Formação Raizama é brusco. 


\section{CAPÍTULO 4 MATERIAIS E MÉTODOS}

Foi realizada uma etapa de campo a fim de efetuar um estudo detalhado das fácies sedimentares do Grupo Araras e coletar amostras em perfis sistemáticos que representassem os diferentes fácies mapeados. Estes dados sedimentológicos e estratigráficos forneceram o arcabouço para os estudos laboratoriais que consistiram de petrografia e análises química e isotópica, que avaliaram as condições de preservação das amostras e mostraram importantes informações a respeito do ambiente e das condições paleoclimáticas em que estas rochas foram depositadas.

\subsection{TRABALHOS DE CAMPO}

Os trabalhos de campo foram realizados numa única etapa, durante 23 dias consecutivos, no mês de julho de 2004. Foram levantadas oito seções litoestratigráficas que constituem uma sucessão estratigráfica contínua de quase $1700 \mathrm{~m}$. Estas foram estudadas separadamente em função da dificuldade de exposição da seqüência completa num único perfil. As camadas encontram-se subverticalizadas na região de Nobres e mergulho de aproximadamente $15^{\circ}$ no flanco sul da Sinclinal Serra Azul e verticais no flanco norte. No total, foram coletadas 144 amostras nos 103 pontos estudados.

\subsection{ESTUDOS PETROGRÁFICOS}

Para este estudo, foram confeccionadas 52 seções delgadas de carbonatos, no Laboratório de Laminação do Instituto de Geociências, Universidade de São Paulo, utilizadas para caracterização dos diferentes fácies sedimentares, bem como para seleção de amostras para análises isotópicas. Para esta última finalidade, o estudo petrográfico consistiu de determinação qualitativa do grau de cristalização e alteração, quantidade dos componentes detríticos, presença de estilólitos e veios, sendo descartadas as amostras que apresentaram elevado grau ou ocorrência destes itens (Kaufman \& Knoll, 1995). Das amostras julgadas como adequadas para análise isotópica, tomou-se a contra parte da respectiva lâmina, na qual se delimitou a área escolhida com estilete, evitando-se contaminação por tinta ou grafite, para pulverização local 
através de microdrilling, utilizando-se brocas diamantadas com diâmetro máximo de 1,5 mm (Figura 17).

\subsection{ANÁLISES QUÍMICAS}

Foram realizadas análises por Fluorescência de Raios-X em 47 amostras calcáreas, no Laboratório de Fluorescência de Raio-X do Instituto de Geociências, Universidade de São Paulo, para os elementos $\mathrm{Si}, \mathrm{Al}, \mathrm{K}, \mathrm{P}, \mathrm{Mn}, \mathrm{Na}, \mathrm{Fe}, \mathrm{Sr}, \mathrm{Rb}, \mathrm{Mg}$ e Ca. As amostras de rocha total foram pulverizadas em moinho de bolas, sendo que para análise dos elementos maiores foram feitas pastilhas de vidro através da fundição das amostras a $1000^{\circ} \mathrm{C}$.

Os resultados adquiridos, conjuntamente ao estudo petrográfico, auxiliaram na identificação do grau de alteração diagenética sofrida pelas rochas carbonáticas. Foram empregados parâmetros de avaliação da alteração das amostras tais como a razão $\mathrm{Mn} / \mathrm{Sr}$, muito utilizada como um critério para detecção de alteração diagenética, sendo aceita como inalteradas amostras com razão menor que 2, conforme proposto por Veizer (1983) e seguido por Derry et al. (1992), Kaufman et al. (1992; 1993), Jacobsen \& Kaufman (1999), embora Fairchild et al. (2000) sejam mais rigorosos propondo uma razão máxima de 0,2. Também pode-se utilizar a razão $\mathrm{Rb} / \mathrm{Sr}$ como indicador da presença de minerais clásticos que possuam teor de $\mathrm{Rb} \mathrm{o}$ suficiente para alterar consideravelmente as razões isotópicas de Sr. Derry et al. (1989) são rigorosos e propõem uma razão $\mathrm{Rb} / \mathrm{Sr}$ igual ou menor que 0,005 para garantir que as razões $\mathrm{Sr} / \mathrm{Sr}$ não tenham sofrido alteração pelo decaimento do $\mathrm{Rb}$.

\subsection{ANÁLISES ISOTÓPICAS}

Todas as análises isotópicas $(\mathrm{C}, \mathrm{O}, \mathrm{Sr}$ e $\mathrm{Sm} / \mathrm{Nd})$ foram realizadas no Centro de Pesquisas Geocronológicas (CPGeo) do Instituto de Geociências, Universidade de São Paulo, seguindo-se os procedimentos laboratoriais rotineiros e descritos a seguir.

\subsubsection{Análises Isotópicas de C e O}

As análises dos isótopos estáveis de carbono e oxigênio foram realizadas simultaneamente. O procedimento consta da reação de $150 \mathrm{mg}$ de amostra pulverizada, de carbonato total contendo dolomita, com $\mathrm{H}_{3} \mathrm{PO}_{4} 100 \%$, em vácuo a $25^{\circ} \mathrm{C}$ por 24 horas $(\mathrm{McCrea}$, 1950). $\mathrm{O} \mathrm{CO}_{2}$ liberado foi purificado numa linha de extração a vácuo com dois loopings estando, o primeiro, imerso numa mistura de álcool $+\mathrm{N}_{2}$ e, o segundo, apenas em $\mathrm{N}_{2}$. Após a purificação, 
estas substâncias foram removidas dos loopings e o $\mathrm{CO}_{2}$ foi extraído para ampolas imersas em $\mathrm{N}_{2}$. As razões ${ }^{13} \mathrm{C} /{ }^{12} \mathrm{C}$ e ${ }^{18} \mathrm{O} /{ }^{16} \mathrm{O}$ do $\mathrm{CO}_{2}$ foram obtidas no espectrômetro de massa Europa Geo20. O padrão utilizado foi o Pee Dee Bellemite (PDB). O erro para estas análises é de cerca de $\pm 0,05 \%$ para $\delta^{13} \mathrm{Ce} \pm 0,1 \%$ para $\delta^{18} \mathrm{O}$.

\subsubsection{Análises isotópicas de $\mathrm{Sr}$}

As razões isotópicas de estrôncio foram obtidas através da reação de $100 \mathrm{mg}$ de carbonato pulverizado com $2 \mathrm{ml}$ de $\mathrm{HCl} 0,1 \mathrm{~N}$ por 1 hora. Retirado o sobrenadante, a amostra foi centrifugada e lavada três vezes com água bidestilada, obtendo-se o primeiro lixiviado, que foi desprezado. A amostra foi seca e a esta foram adicionadas $2 \mathrm{ml}$ de $\mathrm{HCl} 1 \mathrm{~N}$. Após a reação por 30 minutos, a amostra foi centrifugada e lavada três vezes, obtendo-se o segundo lixiviado. O estrôncio deste lixiviado foi purificado através da técnica de troca iônica. Suas composições isotópicas foram determinadas no espectrômetro de massa VG-354. As razões ${ }^{87} \mathrm{Sr} /{ }^{86} \mathrm{Sr}$ obtidas no padrão NBS 987 neste equipamento apresentam um valor médio de 0.710240 , com precisão de \pm 0.00008 .

\subsubsection{Análises isotópicas de Sm-Nd}

As análises isotópicas de $\mathrm{Sm}-\mathrm{Nd}$ foram realizadas em cerca de $50 \mathrm{mg}$ de amostra pulverizada, através da digestão ácida com $\mathrm{HF}, \mathrm{HNO}_{3}$ e $\mathrm{HCl}$. Após a completa dissolução, Sm e $\mathrm{Nd}$ foram purificados através da técnica de troca iônica em duas etapas. Durante a primeira etapa, estes elementos foram separados dos demais elementos terras raras, usando resina RE Spec. Na segunda etapa, os elementos Sm e Nd foram separados utilizando uma coluna de resina LN Spec. As razões isotópicas de $\mathrm{Sm}$ e $\mathrm{Nd}$ foram medidas em espectrômetro de massa multicoletor Finnigan MAT-262. 


\section{CAPÍTULO 5 RESULTADOS}

Neste capítulo serão apresentados os dados obtidos durante o desenvolvimento da pesquisa, desde os resultados estratigráficos adquiridos com a etapa de campo, até aqueles obtidos em etapa laboratorial, por análises química e isotópica.

\subsection{SEÇÕES ESTRATIGRÁFICAS}

Foram realizadas 8 seções litoestratigráficas (Figuras 17 e 18) que constituem uma sucessão estratigráfica contínua de cerca de $1700 \mathrm{~m}$, que abrange todo o Grupo Araras e a Formação Puga. Estas foram estudadas separadamente em função da dificuldade de exposição da seqüência completa num único perfil. Na região de Nobres, as camadas encontram-se subverticalizadas, enquanto que na região de Marzagão (município de Rosário Oeste) as camadas mergulham cerca de $15^{\circ}$ no flanco sul da Sinclinal Serra Azul, passando a verticais no flanco norte da mesma. Ao todo, foram coletadas 144 amostras nos 103 pontos estudados.

As litologias carbonáticas descritas em cada seção seguiram a classificação de Dunham (1962), mais adequada às rochas Pré-Cambrianas desprovidas de fósseis, que leva em consideração a relação entre lama e grãos presentes na rocha (Tabela 3).

Tabela 3. Classificação das rochas carbonáticas segundo Dunham (1962).

\begin{tabular}{|c|c|c|c|c|c|}
\hline \multicolumn{5}{|c|}{ Textura deposicional reconhecível } & $\begin{array}{c}\text { Textura deposicional } \\
\text { não reconhecível }\end{array}$ \\
\cline { 1 - 2 } Componentes originais não unidos durante a deposição & $\begin{array}{c}\text { Componentes } \\
\text { originais unidos } \\
\text { durante a } \\
\text { Contém lama carbonática }\end{array}$ & $\begin{array}{c}\text { Sem lama } \\
\text { deposição }\end{array}$ & $\begin{array}{c}\text { Recristalizado } \\
\text { diageneticamente }\end{array}$ \\
\cline { 1 - 2 } Suportado pela lama & Suportado pelos grãos & & Boundstone & $\begin{array}{c}\text { Carbonato } \\
\text { cristalino }\end{array}$ \\
\hline
\end{tabular}




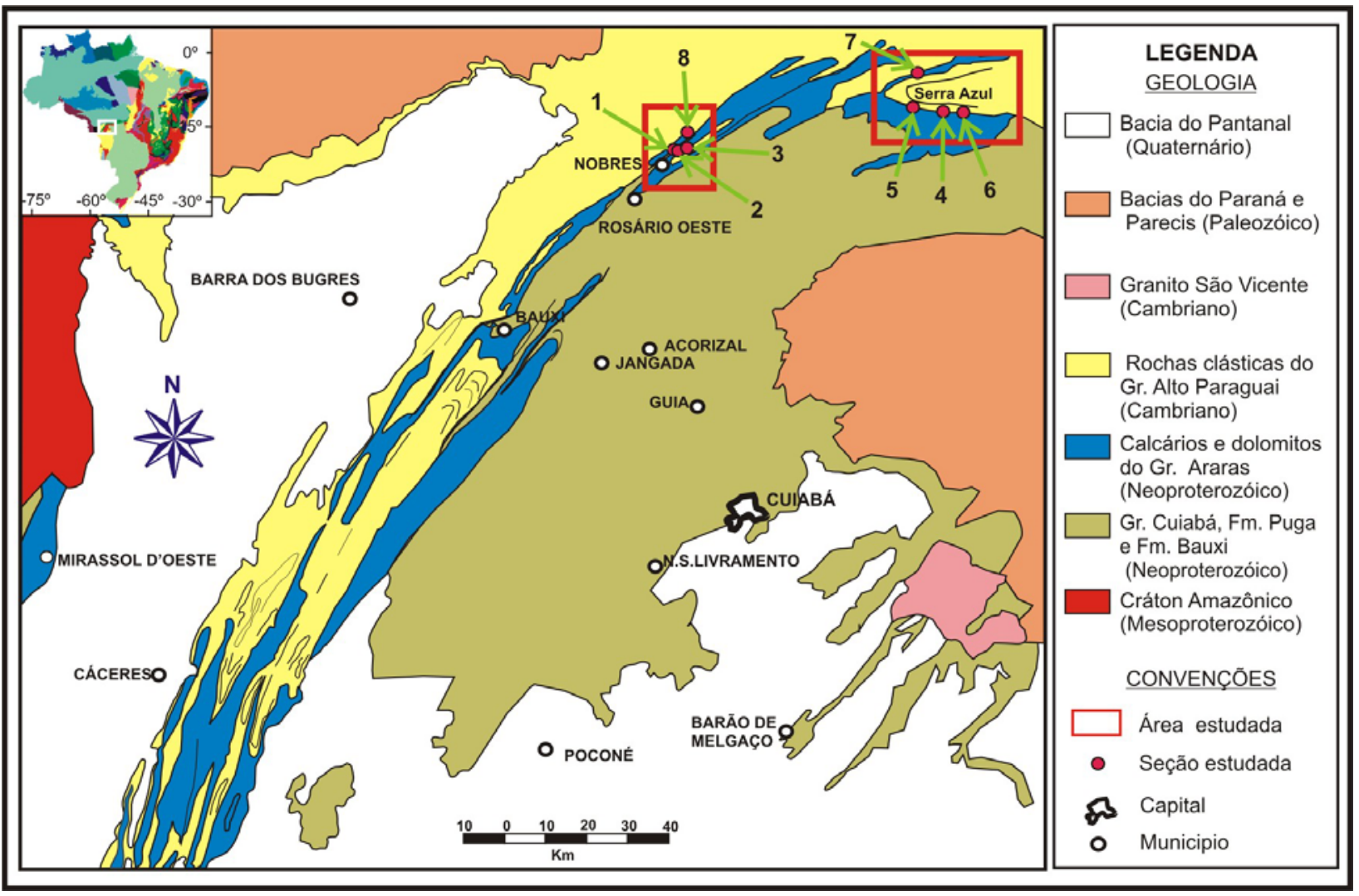

Figura 17. Mapa geológico de localização das 8 seções estudadas.

\subsubsection{Seção 1}

Esta seção foi levantada através de perfil de campo a cerca de $600 \mathrm{~m}$ a noroeste da Pedreira Copacel II (seção 2), em Nobres. Inicia-se no ponto UTM 0575279E/8377352N e termina na BR 364, ponto $0575356 \mathrm{E} / 8377186 \mathrm{~N}$.

Neste perfil levantou-se a sucessão de rochas mais basal da Formação Guia, que se encontra estratigraficamente sobreposta aos diamictitos da Formação Puga (Figura 18). Este diamictito, no local, apresenta-se maciço, com seixos e pequenos blocos máficos e graníticos esparsos, suportados por matriz arenosa vermelha violácea (Figura 19A). O contato basal da Formação Guia com o mesmo não pode ser observado, assim como os primeiros $20 \mathrm{~m}$ basais, devido aos depósitos de talus provenientes do morrote sustentado pelo diamictito. A Formação Guia é composta, da base para o topo, por mudstone preto laminado (Figura 19F), mudstone cinza escuro com laminação ondulada (Figura 19B) e nódulos alongados de chert preto póscompactação com calcário preservado no seu interior (Figura 19C), lâminas de mudstone intercaladas com lâminas de grainstone granodecrescentes, de areia muito fina a argila (Figura 19D), mudstone preto maciço impuro e mudstone cinza com laminação irregular, possivelmente biogênica (Figura 19 G). 

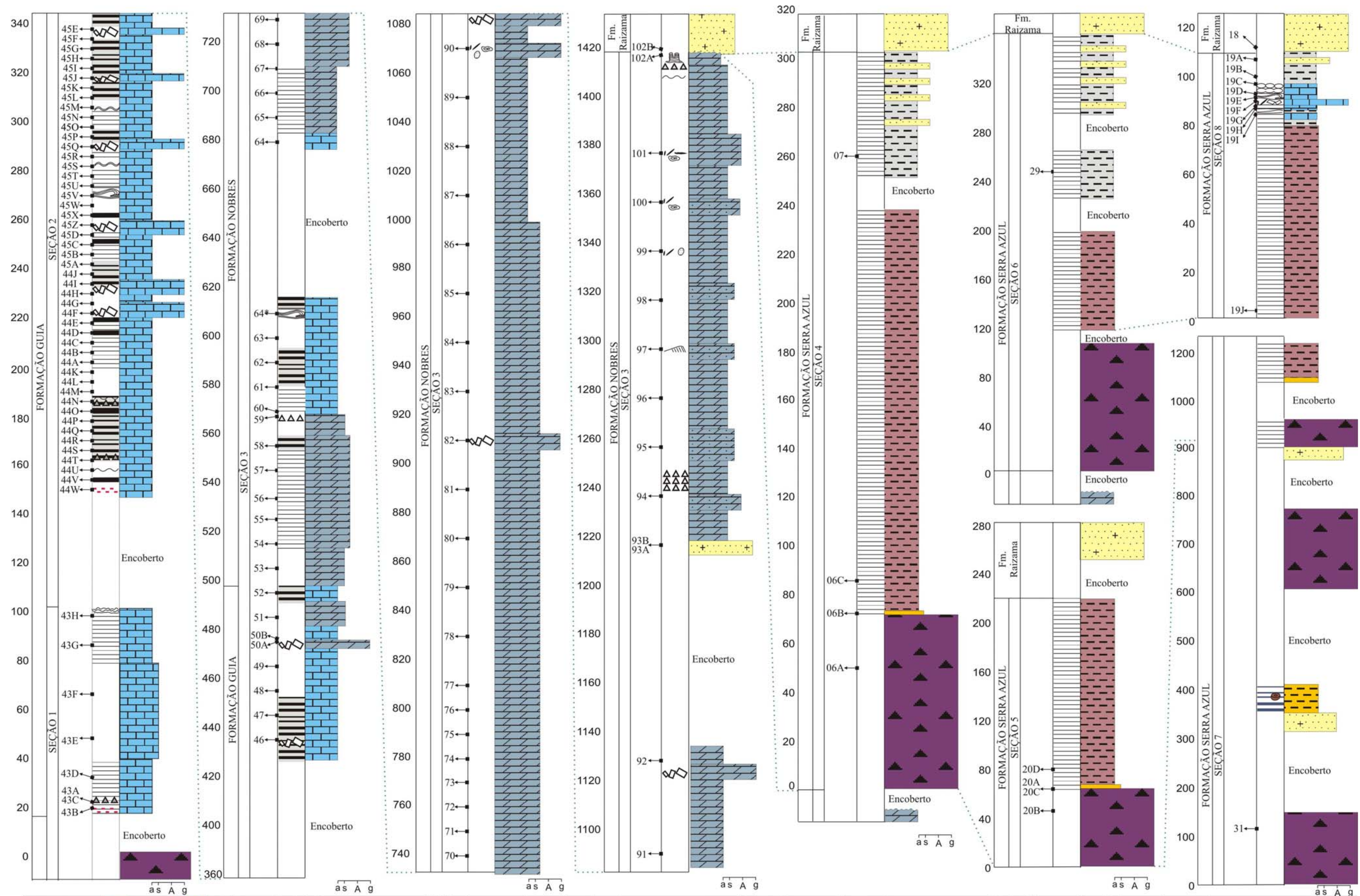

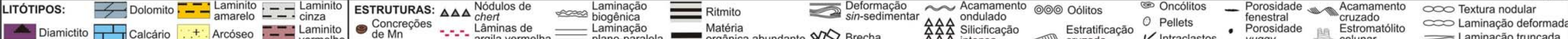
as $\dot{A} g$
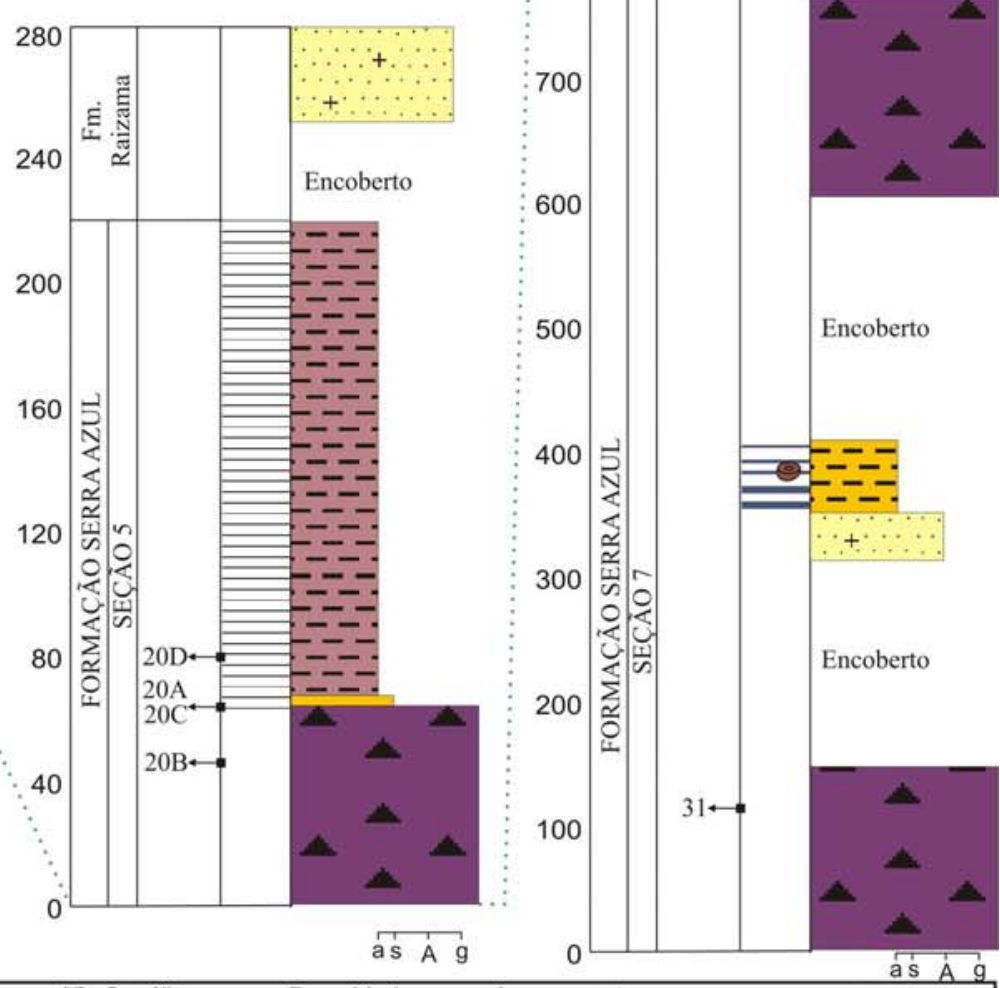

Figura 18. Colunas estratigráficas das 8 seções estudadas. 
Embora fossem poucos os afloramentos expostos, pôde-se amostrar uma seção de aproximadamente $80 \mathrm{~m}$, com intervalos irregulares de 2,5 a $20 \mathrm{~m}$, totalizando 8 amostras coletadas.

\subsubsection{Seção 2}

A seção 2 foi detalhada na frente de lavra da Pedreira Copacel II, em Nobres, coordenadas UTM 0575873E/8377130N (Figuras 17 e 18).

Nesta pedreira se observa uma sucessão carbonática de quase $200 \mathrm{~m}$ de espessura, em camadas subverticais, da porção mediana-topo da Formação Guia (Figura 20). Em direção ao topo têm-se camadas centimétricas de mudstone cinza com intercalação de lâminas de argila vermelha, alternadas com camadas de mudstone laminado preto com filmes de matéria orgânica sobrepostas por hummockys.

Estes mudstones pretos costumam apresentar texturas grumosa (clotty) e peloidal intercaladas, com freqüente presença de microesferas nas lâminas mais claras, que sugerem a preservação de algas, assim como a presença de pirita envolta por aglomerados nas lâminas mais ricas em matéria orgânica, indicativos de colônias de bactéria redutora de enxofre (Figura 28 no item V.2).

Seguem-se mudstone laminado rítmico, alternando pares claro (microesparita) e escuro (micrita rica em matéria orgânica), com algumas camadas de dolomudstone rítmico apresentando nódulos alongados de chert preto próximo à base da seção (Figuras 21A e 21B). Ocorrem camadas muito finas de packestone, produzido por brechamento in situ de mudstone rítmico, sobreposta em contato erosivo plano por mudstone rítmico (Figura 21C) com pares granodecrescentes (areia muito fina a argila). Na porção média da seção, intercalam-se pacotes métricos de mudstone rítmico (Figura 20B), pacotes de mudstone laminado rico em matéria orgânica (Figura 20D), lentes decimétricas a métricas de mudstone cinza claro e wackestone maciço, com matriz cinza e clastos variando de seixos a pequenos blocos arredondados e alongados de mudstone preto da camada sotoposta (Figuras $21 \mathrm{~F} \mathrm{e} 21 \mathrm{H}$ ). 

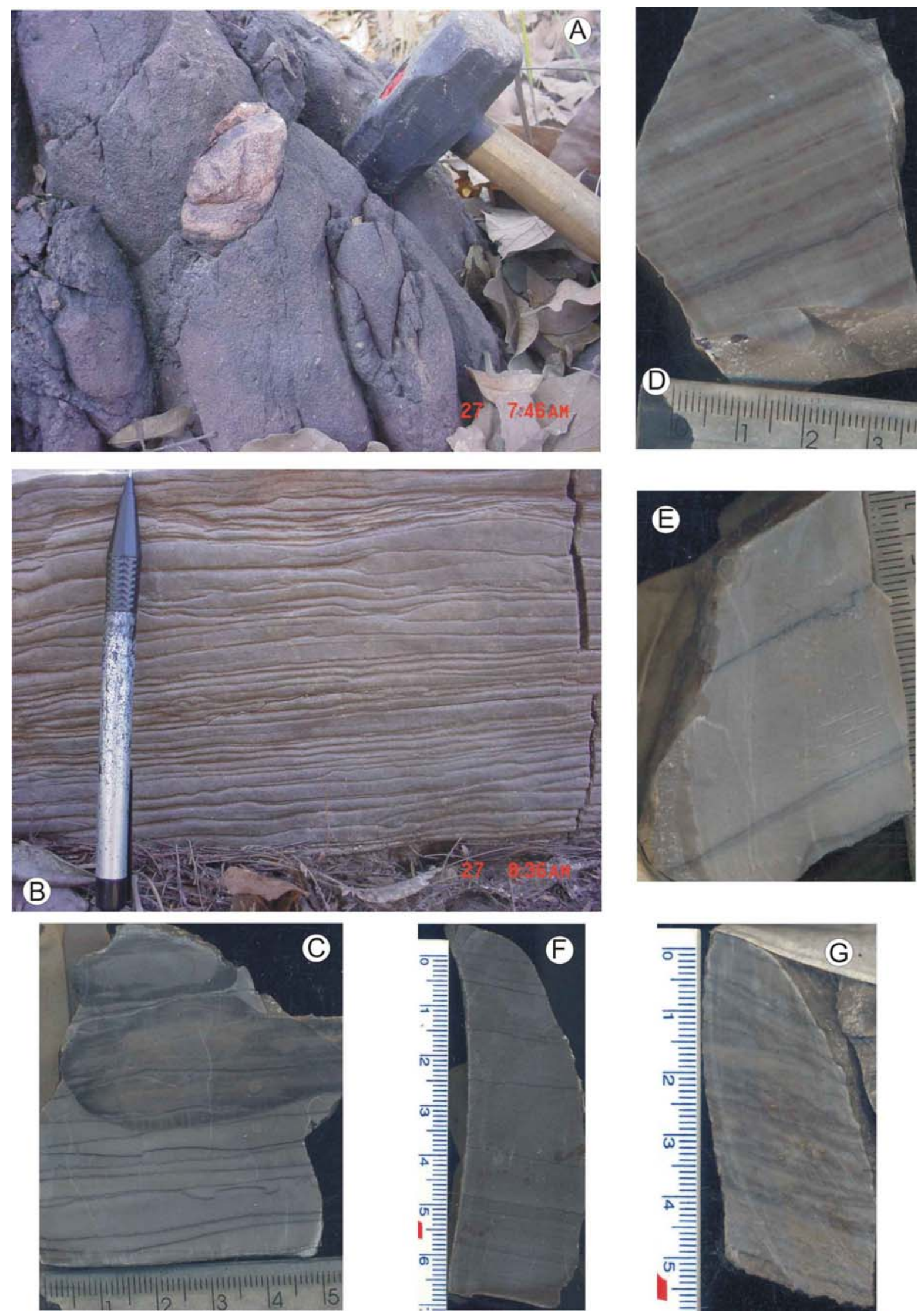

Figura 19. Fotos da Seção 1, Formação Guia: (A) diamictito da Formação Puga com clasto granítico, (B) laminação ondulada e truncada, (C) chert preservando calcário no interior, (D) mudstone laminado, (E) mudstone maciço, (F) mudstone preto laminado e (G) laminação irregular possivelmente biogênica. 


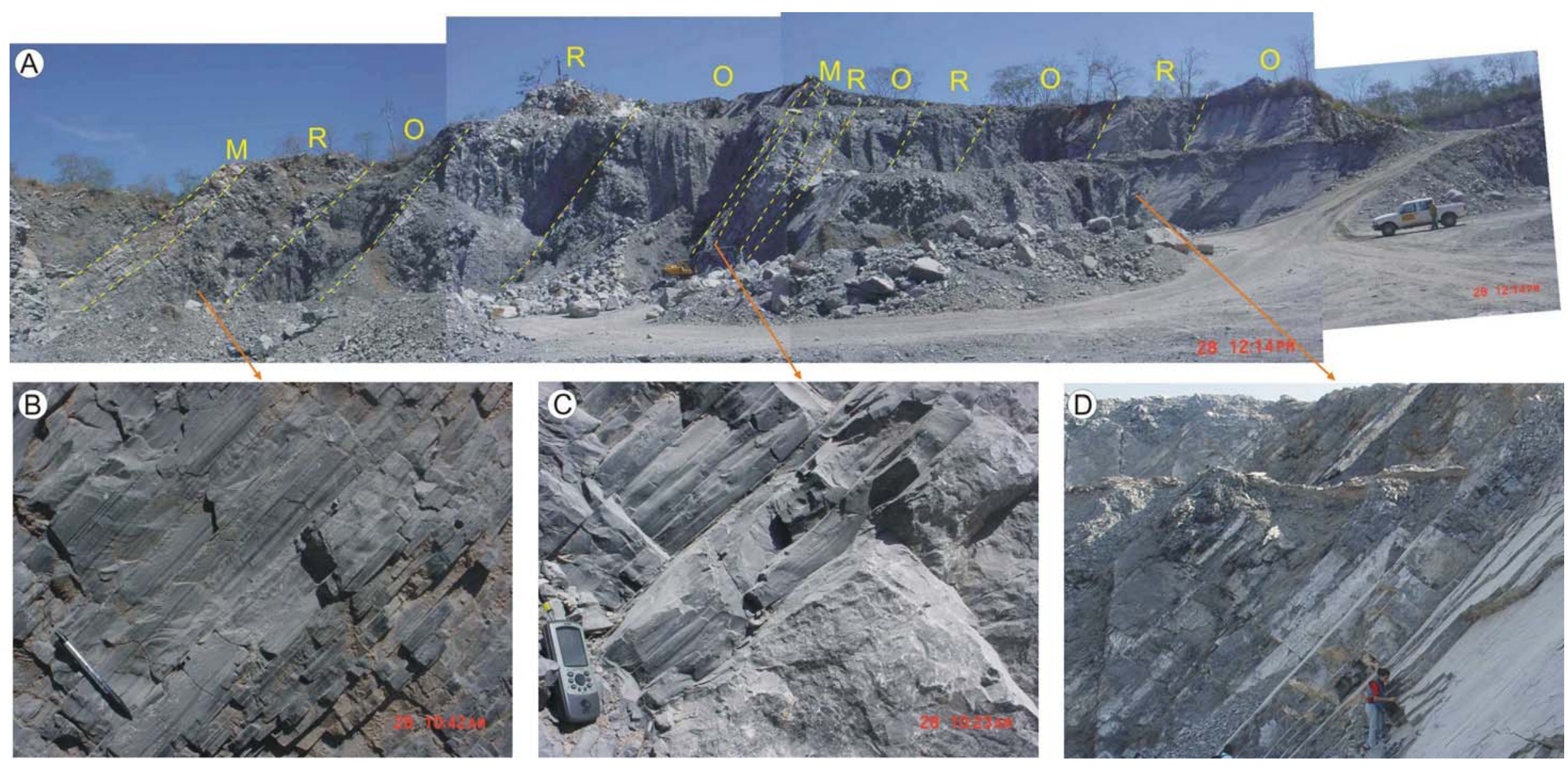

Figura 20. Foto (A) panorâmica da Pedreira Copacel II (Seção 2, Formação Guia), estando o topo para a esquerda, com fotos de detalhe com visada no mesmo sentido. Existe intercalação persistente de mudstone finamente laminado rico em matéria orgânica $(\mathrm{O})$, mudstone rítmico contendo algumas lentes de wackestone intraclástico (R), e lente de mudstone maciço (M) que ocorre sempre em contato com os ritmitos. Em (B) um detalhe dos ritmitos alternando pares claro-escuro; em (C) contato de topo ondulado entre o mudstone maciço e o ritmito e (D) passagem do ritmito laminado (direita) para o mudstone finamente laminado rico em matéria orgânica (esquerda). 
O topo destas lentes de mudstone claro costuma ser ondulado (Figuras 20C e 21E), enquanto que a base mostra-se plana. Em direção ao topo, observa-se o aumento do ritmitos. Em alguns casos, os ritmitos encontram-se depositados concordantemente sobre lentes de grainstone de granulometria média, com a laminação rítmica sobreposta intensamente microfalhada, podendo se tratar de um possível sismito. Ocorrem em algumas lâminas claras de mudstone microsilicificação pontual (Figura 21I). Também se observou um estreito nível $(1 \mathrm{~cm})$ de laminação rítmica dobrada e falhada (Figura 21D), possivelmente por escorregamento. No topo ocorrem espessas lâminas de wackestone ou grainstone com base irregular sobrepostas por laminação rítmica com pares granodecresdentes (silte-argila), podendo se tratar de um turbidito.

Entre o topo da seção 1 e a base desta seção, há cerca de $50 \mathrm{~m}$ encobertos pelo manto de alteração intempérica, não sendo possível observar a transição. A coleta foi realizada sistematicamente a cada $4 \mathrm{~m}$, resultando um total de 52 amostras (Figura 18).

\subsubsection{Seção 3}

O perfil desta seção se inicia a cerca de $100 \mathrm{~m}$ a sudeste da pedreira Copacel II (UTM 0575723E/8376893N), Nobres, e termina no topo da Serra "Vai quem qué" $(0577735 \mathrm{E} / 8376588 \mathrm{~N})$.

A seção 3 constitui a porção superior da Formação Guia e toda a Formação Nobres (Figura 18). Persiste pelos primeiros $240 \mathrm{~m}$ a mesma sucessão de mudstone laminado rítmico intercalado a espessas lentes de wackestone e packestone, semelhante ao que está descrito na seção 2, e dolomito cristalino, inicialmente guardando laminação rítmica (Figuras 22A e 22F), passando a dolomito cristalino com microdrusas (Figuras 22B e $22 \mathrm{C}$ ). A quantidade de dolomito aumenta em direção ao topo.

Nos 450 m restantes tem-se uma monótona sucessão de dolomitos, inicialmente dolomito cristalino poroso de cor cinza claro e branco, com laminação primária incipiente, preservada da cristalização. Ocorrem, na porção intermediária, dolopackestone, dolograinstone, seguidos de duas camadas de arcóseo, sendo uma cinza com matriz de granulometria média e feldspatos de 1

$\mathrm{cm}$ e o outro róseo com matriz de granulometria fina e feldspatos de 3-5 cm, não observado sua relação de contato com os carbonatos. 

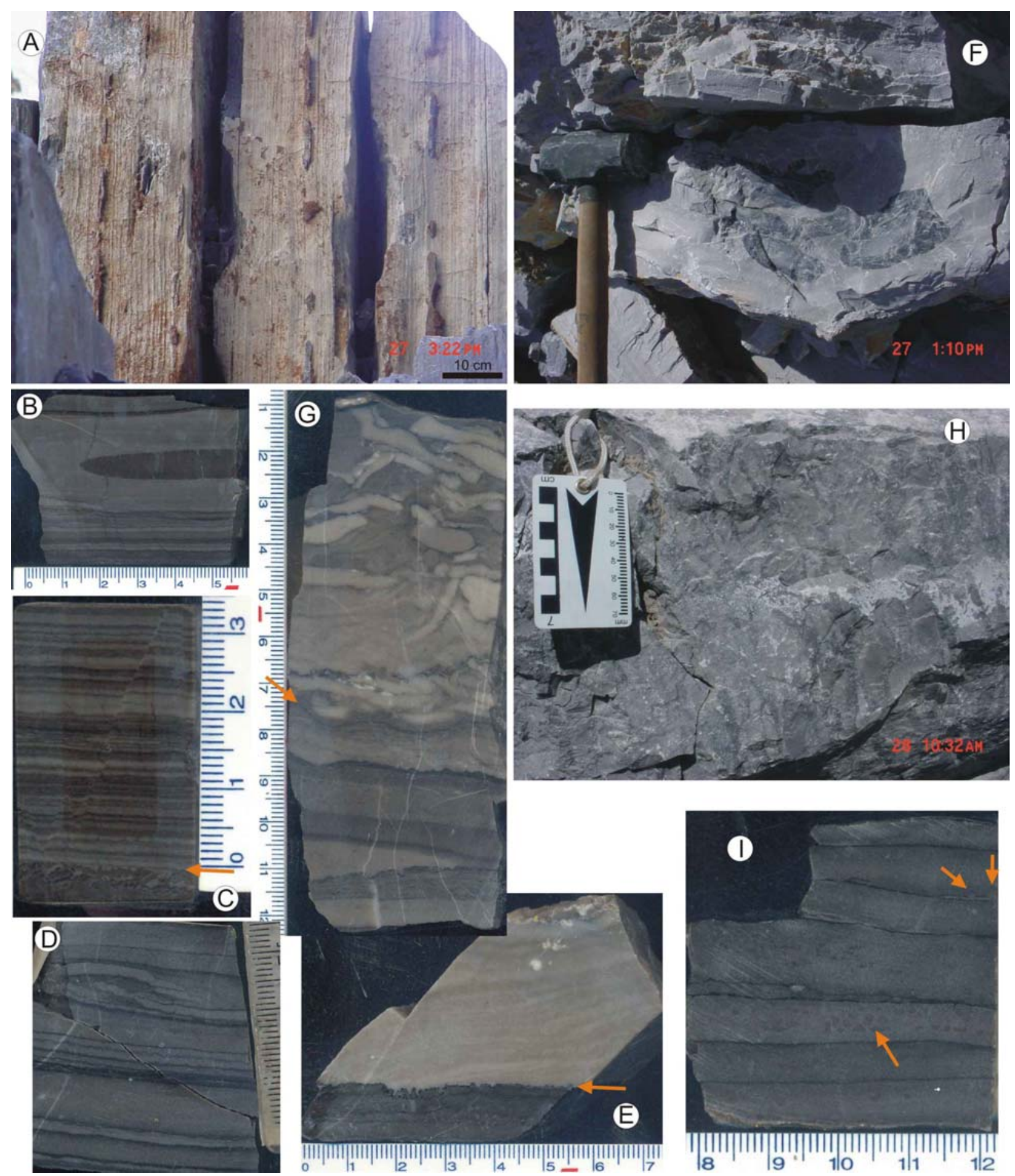

Figura 21. Fotos dos calcários da Seção 2: (A) mudstone laminado com nódulos alongados de chert preto, em acamamento vertical; (B) detalhe de (A); (C) packestone originado por brechação de mudstone rítimico sobreposto por mudstone rítmico fraturado, notar contato plano-erosivo; (D) laminação rítmica com camada dobrada por escorregamento; (E) contato entre mudstone preto e mudstone claro com laminação irregular deformado por estilólito; (F) wackestone de clastos de calcário preto imerso em calcário claro; $(\mathrm{G})$ mudstone e wackestone em finas camadas truncadas sobreposto por packestone de intraclastos claros e matriz escura, em contato deformado; $(\mathrm{H})$ wackestone de intraclastos escuros imersos em matriz clara; (I) mudstone em finas camadas contendo nódulos de silicificação pontual, comumente resistentes aos estilólitos. 
Seguem-se dolomudstone impuro (Figura 22E), um espesso nível (cerca de $5 \mathrm{~m}$ ) intensamente silicificado (Figura 22D), apresentando laminação e acamamento deformados, sobreposto por dolomudstone com impurezas na fração areia fina, com laminação truncada contendo nódulos de chert (Figura 22G). Em direção ao topo ocorrem dolomudstone cinza maciço, seguindo-se dolograinstone oolítico e dolowackestone róseo com grande quantidade de terrígenos, apresentando seqüência cíclica por vários metros, sendo reconhecíveis uma laminação agradacional seguida de estratificação cruzada tipo climbing e laminação planoparalela granodecrescente (Figura 23A). Poucos metros mais acima, nesta seqüência cíclica ocorre estratificação cruzada tipo hummocky. Ocorre, então, dolomudstone cinza em finas camadas granodecrescentes (Figura 23F), seguindo-se alternância de finas camadas de dolograinstone oncolítico e peloidal com porosidade tipo vuggy e dolomudstone primário (Figura 23E). Sobrepõe-se dolograinstone de intraclastos e oncólitos com porosidade fenestral (Figura 23C). Seguem-se, dolomudstone arenoso, em finas camadas separadas por lâminas irregulares de chert branco (Figura 22), e estromatólitos dendróides, com algumas pontes entre as colunas, evoluindo para esteiras algais e novamente para estromatólitos colunares (Figura 23D). Observase contato brusco com os arenitos da Formação Raizama, apresentando granulometria fina e laminação plano-paralela em sets truncados de baixo ângulo, com algumas pelotas de argila entre as lâminas $(23 G)$.

O intervalo de amostragem variou de 10-20 m, somando 50 amostras, ao longo de uma sucessão carbonática com 690 m.

\subsubsection{Seção 4}

Esta seção constitui o estratótipo da Formação Serra Azul, aflorante na região de Marzagão, Mato Grosso, ao longo da estrada de leito natural utilizada para subir a Serra Azul. Estruturalmente encontra-se no flanco sul, de menor mergulho $\left(\sim 15^{\circ}\right)$ da Sinclinal Serra Azul, assimétrica.

$\mathrm{Na}$ base, ocorre diamictito maciço, sustentado pela matriz silto-arenosa vermelha, com clastos extraformacionais de quartzitos, arenitos, carbonatos, chert, rochas graníticas e máficas (Figuras 24A, 24B, 24C). Os clastos variam em tamanho, de grânulos a blocos, e na forma, de arredondados a angulosos, com esfericidade variável. Alguns deste clastos se apresentam estriados, polidos ou facetados (Figuras 25B, 25C, 25D, 25E). Esses diamictitos possuem uma espessura mínima de $70 \mathrm{~m}$. 

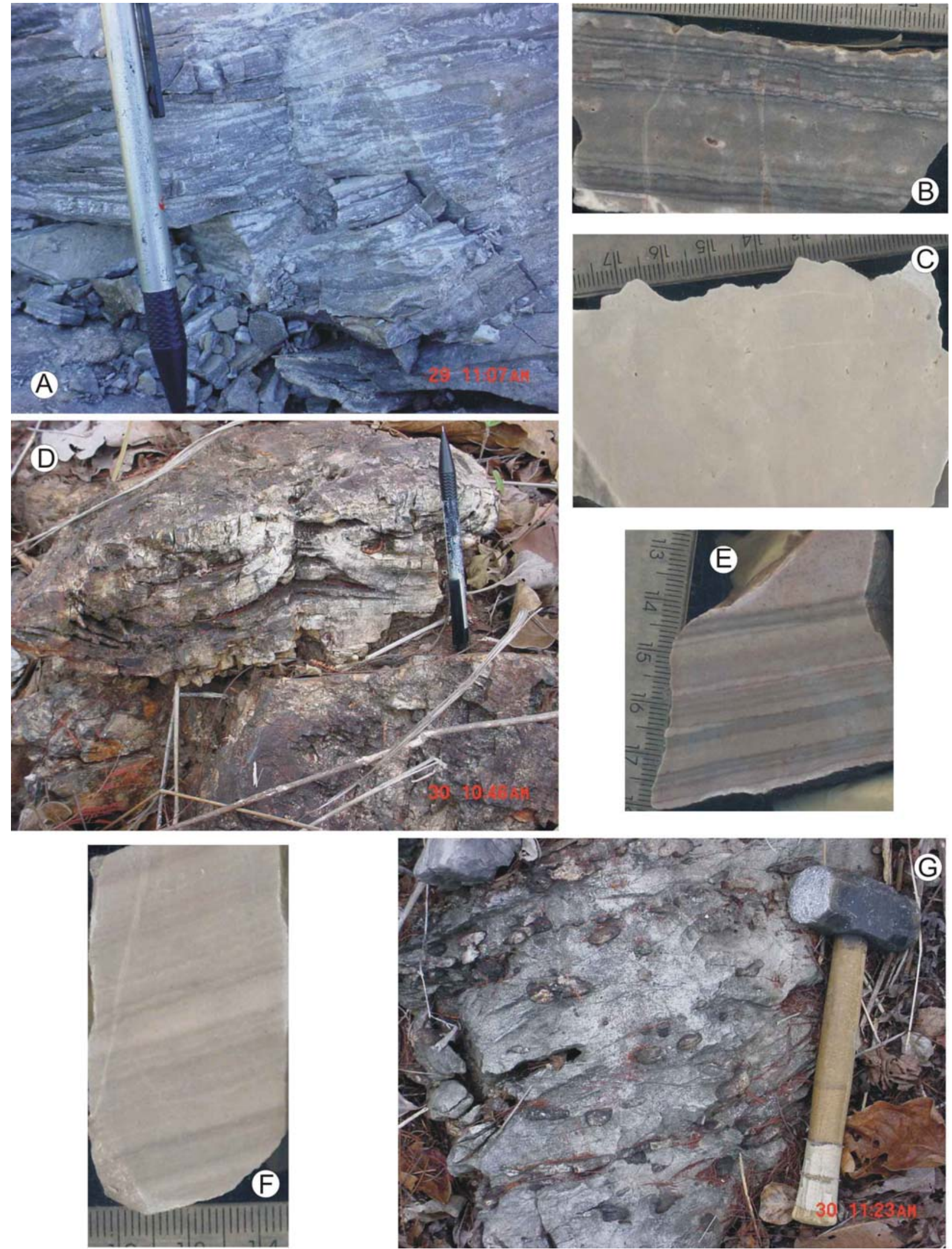

Figura 22. Fotos da Seção 3, na sua porção basal-mediana: (A) ritmito dolomitizado; (B) porosidade causada pela dolomitização; (C) dolomitização intensa, sem evidências de estruturas primárias; (D) silicificação intensa, notar estrutura arqueada para cima, possível tepee; (E) mudstone laminado rico em óxido de ferro; (F) dolomudstone secundário apresentando fantasmas da laminação; $(\mathrm{G})$ dolomudstone com nódulos de chert. 

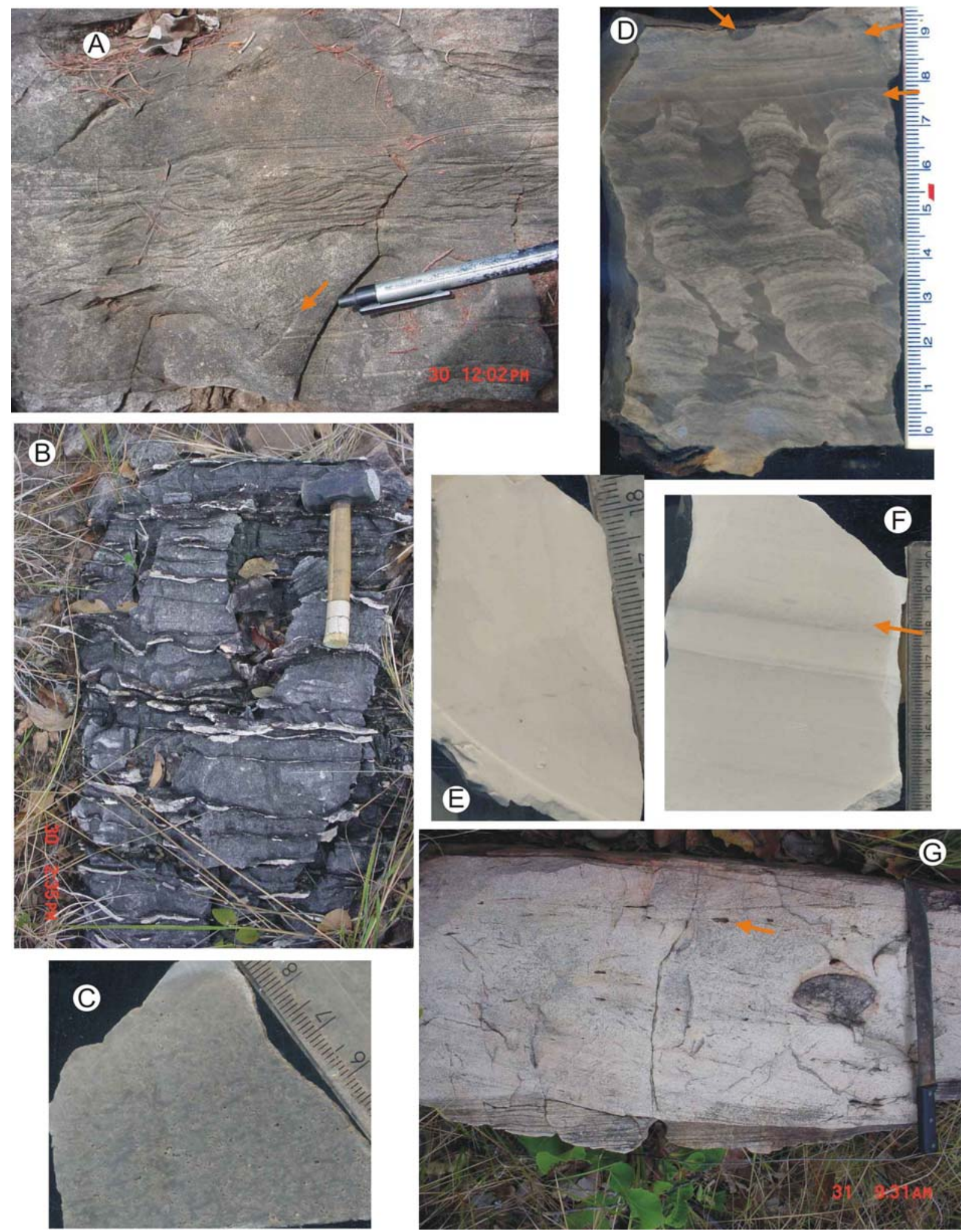

Figura 23. Fotos da Seção 3, na porção mediana-superior: (A) seqüência turbidítica em dolomudstone impuro, apresentando estrutura de corte, preenchida por laminação agradacional e seguida de laminação cruzada tipo climbing e laminação granodecrescente; (B) dolomudstone com lâminas deformadas de chert branco intercaladas; (C) dolograinstone de intraclastos e oncólitos granodecrescente, com porosidade fenestral; (D) estromatólito dendróide evoluindo para esteiras algais (relação deformada por estilólitos) e novamente para colunas; (E) dolomudstone primário; (F) dolomudstone primário granodecrescente nas porções mais escuras; $(\mathrm{G})$ arenito da Formação Raizama apresentando laminação em camadas truncadas, com pelotas de argila nos planos de laminação. 
Sobre o diamictito ocorre um laminito síltico amarelo, com laminação paralela e esparsos grânulos variegados, tanto na composição (predominantemente quartzo e chert), quanto na forma, constituindo uma camada persistente na região de cerca de $60 \mathrm{~cm}$ de espessura. Os contatos basais e de topo são bruscos e planos.

$\mathrm{Na}$ sucessão, observa-se uma espessa seqüência sobreposta, de cerca de $200 \mathrm{~m}$ de espessura, composta de laminito síltico vermelho (Figura 24D), com laminação plano-paralela a suavemente ondulada, com grânulos bastante esparsos, gradando para um laminito argiloso cinza (Figura 24E), com laminação plano-paralela rítmica. Seguem-se intercalações de arenito muito fino aparentemente maciço cada vez mais freqüentes conforme se aproxima do topo.

O contato com a Formação Raizama é brusco e irregular, passando de um arenito médio a um conglomerado grosso de matriz arenosa (Figura 24F), cimentado por óxido de ferro, suportado por grãos de quartzo fosco (Figura 24). Os grânulos de quartzo são subarredondados com esfericidade média.

Assim, ocorre uma seqüência inicial granodecrescente, dos diamictitos aos laminitos cinza, seguida de uma seqüência granocrescente, dos laminitos cinza aos conglomerados da Formação Raizama. No total foram coletadas 7 amostras, em intervalos decamétricos irregulares.

\subsubsection{Seção 5}

A seção 5 encontra-se cerca de $10 \mathrm{~km}$ a oeste da seção 4, nos limites da Fazenda Serra Azul com a Fazenda Sete Estrelas, onde se observa apenas uma parte intermediária da Formação Serra Azul. Estruturalmente localiza-se no flanco sul da Sinclinal Serra Azul, com mergulho máximo de $30^{\circ}$.

Observa-se nesta seção os últimos $63 \mathrm{~m}$ de topo do diamictito, com matriz silte-argiloarenosa vermelha suportanto os clastos. Estes clastos são compostos de arcóseo maciço, arcóseo estratificado, arenito conglomerático, chert e raros carbonatos. O tamanho e forma destes clastos variam de $2 \mathrm{~mm}$ a $1,5 \mathrm{~m}$, de arredondados a angulosos, e esfericidade alta a média.

Depositada sobre os diamictitos encontra-se uma camada de laminito síltico amarelo, físsil, com vários grânulos de quartzo, feldspato, biotita e seixo de biotita-quartzito. Este nível de laminito amarelo possui $0,75 \mathrm{~cm}$ de espessura.

Acima deste laminito amarelo é possível observar apenas os primeiros $25 \mathrm{~m}$ da porção basal do laminito silto-argiloso vermelho (Figura 24D), com laminação plano-paralela a levemente ondulada. 

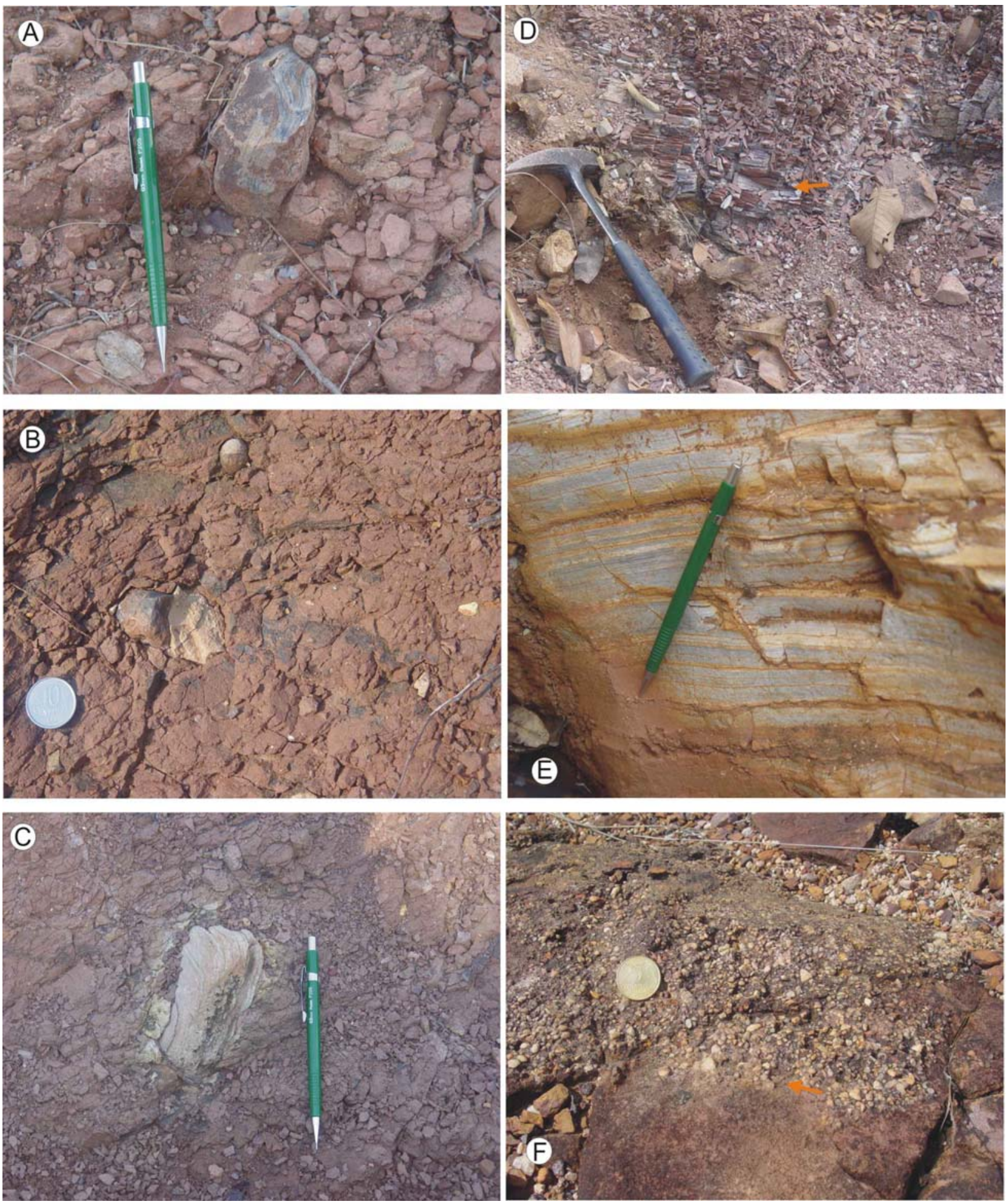

Figura 24. Fotos da Formação Serra Azul na região da Serra Azul (seções 4, 5, 6 e 7): (A) diamictito maciço contendo pequeno bloco de chert; (B) diamictito maciço contendo seixo arredondado de arenito e bloco anguloso de carbonato em contato com chert; (C) diamictito maciço com pequeno bloco de carbonato laminado; (D) laminito vermelho em afloramento alterado, apresentando ondulação simétrica; (E) laminito cinza aparentemente rítmico; (F) contato brusco entre arenito e conglomerados da Formação Raizama, cimentados por óxido de ferro. 
Os próximos 260 m em direção ao topo encontram-se encobertos pelo manto intempérico, observando-se no topo intercalações de espessas camadas de arenito médio e estreitas camadas de siltito laminado cimentado por óxido de ferro.

\subsubsection{Seção 6}

Esta seção é localizada cerca de $4 \mathrm{~km}$ a leste da seção 4, próximo à sede da Fazenda Beleza, também no flanco sul da Sinclinal Serra Azul. Os afloramentos desta seção são poucos e ocorrem unicamente em ravinas erosivas ou em caminhos feitos há algumas décadas por cavalos para subir a Serra Azul.

$\mathrm{Na}$ base da seção encontra-se um diamictito semelhante ao descrito nas seções anteriores, com matriz silte-arenosa vermelha, com laminação anastomosada incipiente, sustentando clastos de chert, carbonato, siltito e arenito (Figura 24C). Os clastos variam em tamanho de grânulos a pequenos blocos e na forma de angulosos a arredondados, com média a alta esfericidade. Observa-se que em direção à base aumenta a quantidade de areia fina.

Sobreposto aos diamictitos, encontra-se um laminito vermelho silto-argiloso, finamente laminado. Suas relações de contato basal e de topo não foram observadas. Acima deste laminito vermelho, encontra-se um laminito cinza argilo-síltico, apresentando coloração amarelada devido à alteração intempérica. Ocorre intercalado a este laminito cinza uma camada muito fina e persistente de material de coloração esbranquiçada na fração silte (Figura 25G).

Próximo ao contato com a Formação Raizama, ocorrem camadas de folhelho ferruginoso com concreções de manganês, seguidas por intercalações cada vez mais freqüentes de camadas de arenito, em direção ao topo, apresentando um espessamento das camadas e aumento da granulometria de fina a média. A espessura total da seção é de $600 \mathrm{~m}$, na qual foram coletadas apenas 2 amostras.

Os afloramentos desta seção são escassos devido ao manto intempérico, sendo característico da alteração autóctone dos diamictitos um solo com freqüentes clastos na superfície, chegando a formar mademoiselles gigantes (Figura 25A).

\subsubsection{Seção 7}

A seção 7 está localizada cerca de 13 km a norte do estratótipo da Formação Serra Azul (seção 4), no flanco norte da Sinclinal Serra Azul, de maior mergulho $\left(75^{\circ}\right.$ a $\left.90^{\circ}\right)$. 
Embora as exposições sejam poucas e ruins, podem-se observar alguns afloramentos. No início da seção foi observado diamictito em afloramentos de rochas bastante alteradas, com clastos soltos na superfície, de matriz silte-argilosa vermelha bastante micácea, com laminação anastomosada incipiente.

Estratigraficamente acima, ocorre nível marcado por chert branco associado a fragmentos de arenito e carbonato intensamente silicificado sustentando altos morros. Depositada pouco acima observa-se camada de laminito amarelo argilo-síltico contendo lâminas de material síltico de coloração esbranquiçada associado a lâminas ricas em manganês e hematita (Figura 25H). Pouco mais acima na estratigrafia, é possível observar dentro de pequena ravina um laminito argilo-síltico amarelo, seguido de um laminito vermelho. Mais acima, encontram-se camadas de arcóseo e arenito sustentando pequenos morrotes, seguidos de diamictito síltico vermelho, com laminação incipiente ondulada, contendo esparsos clastos de arenito grosso e fino, arcóseo, lamito, hematita, conglomerado, chert, carbonato (Figura 25F), material argiloso branco (alteração de carbonato muito fino) e argiloso verde (possivelmente alteração de rocha básica), variando em tamanho de grânulos a pequenos blocos, e na forma de angulosos a subangulosos, com esfericidade variável. Alguns destes clastos encontram-se facetados (Figura 25F).

O perfil possui cerca de $1200 \mathrm{~m}$ de sucessão rochosa, tendo-se coletado apenas 3 amostras preservadas.

\subsubsection{Seção 8}

A seção 8 constitui a parte superior da Formação Serra Azul e foi estudada na reserva ambiental (antiga cava de argila) da Indústria de Cimento Itaú. Encontram-se expostos cerca de $80 \mathrm{~m}$ de laminito vermelho silte-argiloso (Figura 26A). É encontrado nesta seção o contato de topo deste laminito vermelho com um laminito cinza argilo-siltico, que se apresenta gradacional. Pouco acima do contato, encontra-se uma camada de cerca de $12 \mathrm{~m}$ de calcário, sobre a qual ocorre mais cerca de $30 \mathrm{~m}$ de laminito cinza.

A camada calcária é constituída, da base para o topo, de mudstone com laminação planoparalela, mudstone maciço (Figura 26G) com estrutura de corte preenchida por wackestone de matriz na fração areia fina e intraclastos de $3 \mathrm{~mm}$ do mudstone inferior (Figura 26H). Segue-se mudstone com laminação plano-paralela (Figura 26B), sendo que algumas lâminas intercaladas apresentam textura tipo grumosa (Figura 28C no item 5.2). 

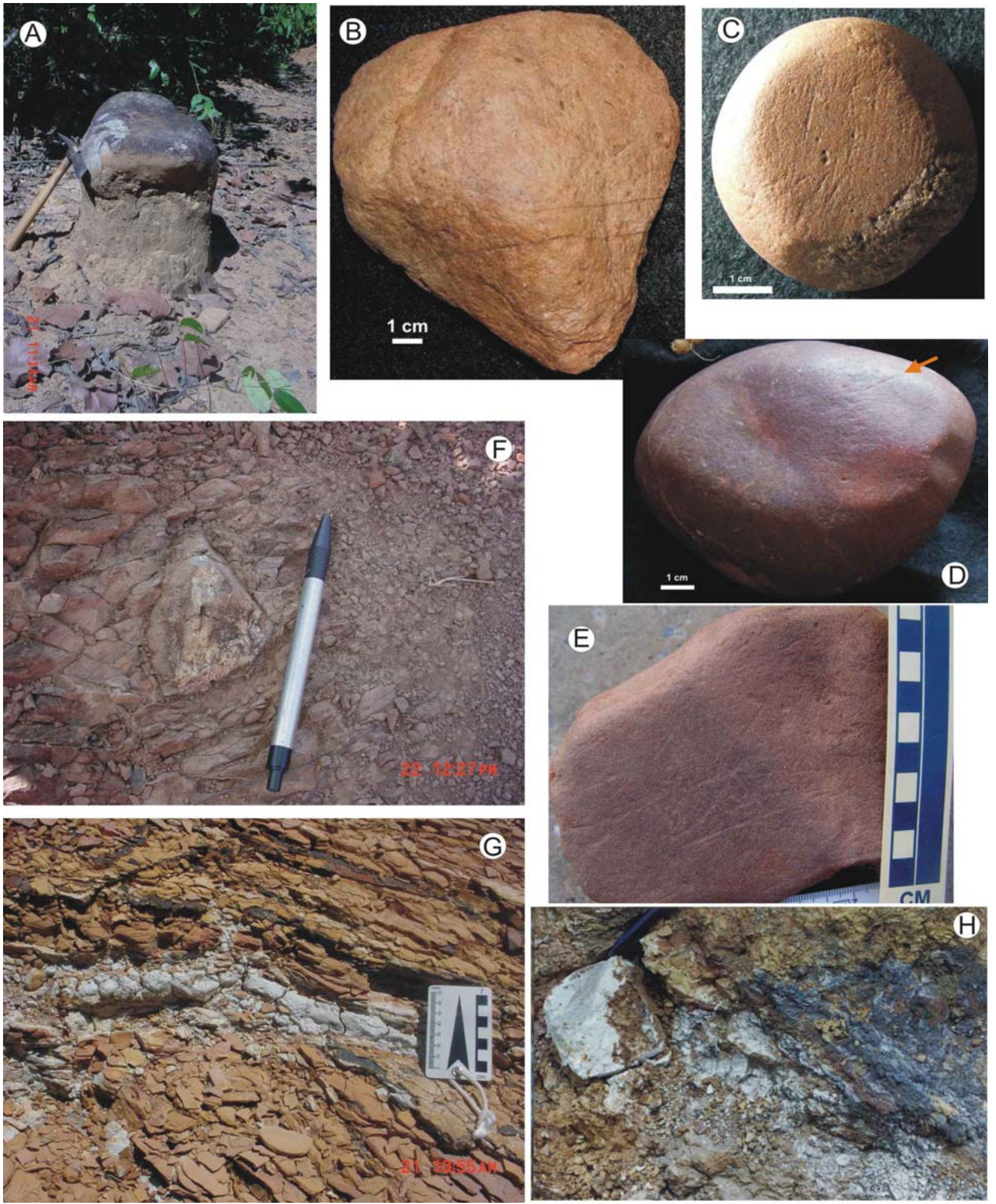

Figura 25. Fotos da Formação Serra Azul na região homônima (seções 4, 5, 6 e 7): (A) padrão de alteração intempérica dos diamictitos, como se vê na mademoiselle gigante de arenito; (B) clasto retirado do diamictito de granito em forma de ferro de engomar; (C) clasto oblato de granito fino em contato com granito médio, retirado do diamictito, mostrando sua superfície toda estriada por intensa abrasão, especialmente aquelas planas e de maior área; (D) clasto de quartzito polido, retirado do diamictito, com algumas estrias mais evidentes; (E) clasto de arenito, retirado do diamictito, com base plana estriada; (F) diamictito com laminação incipiente com clasto de carbonato em forma de ferro de engomar; $(\mathrm{G})$ laminito amarelo ferruginoso, com fina camada síltica branca persistente; $(\mathrm{H})$ laminito amarelo com camadas de material siltoso de coloração esbranquiçzada e de laminito rico em ferro e manganês. 
Mais acima, ocorre mudstone com laminação truncada com desmicrita, recoberto por laminação plano-paralela. Pode-se observar ciclos repetitivos de sucessões de brechas, deformação por escorregamento e laminação plana (Figuras 26C, 25D), às vezes com fina lâmina de argila vermelha (Figura 26E). Sobreposto, ocorre camada de mudstone laminado, apresentando uma deformação progressiva destas lâminas em direção ao topo, até assumir uma textura nodular (Figura 26F), provavelmente devido à forte compactação de lama em estado plástico. Acima desta camada, encontra-se mudstone com laminação aparentemente rítmica, marcada principalmente por pares claro-escuro que se estreitam para ao topo.

O laminito cinza situado abaixo da camada calcárea é laminado e aparentemente rítmico, enquanto que acima dos calcáreos possui textura nodular. Segue-se intercalação de camadas de arenito fino no topo, gradando para a Formação Raizama.

Os calcários foram amostrados com intervalos irregulares de 1,2 a 4 m, num total de 11 amostras coletadas.

\subsection{PETROGRAFIA}

Foram confeccionadas seções delgadas com espessura de $0,003 \mathrm{~mm}$ para a realização de estudo petrográfico, sendo 50 seções de carbonatos, 01 de dique básico intrudido nas rochas do Grupo Araras e 01 de clasto do diamictito. Neste estudo, procurou-se melhor classificar os litótipos encontrados, suas texturas e estruturas, podendo-se melhor interpretar seu ambiente de formação. Além disso, o estudo petrográfico foi essencial na escolha de amostras para análise isotópica dos carbonatos, através da identificação de microestruturas e processos secundários que pudessem influenciar as razões isotópicas originais, ou seja, permitiram selecionar amostras que representam a composição isotópica da água do mar da época de sua deposição. Ao avaliar microscopicamente as amostras, selecionou-se a porção com menor risco de alteração pósdeposicional e efetuou-se a retirada da amostra com broca diamantada (microdrilling) da contraparte da lâmina. As descrições das seções delgadas serão apresentadas abaixo na Tabela 4. 

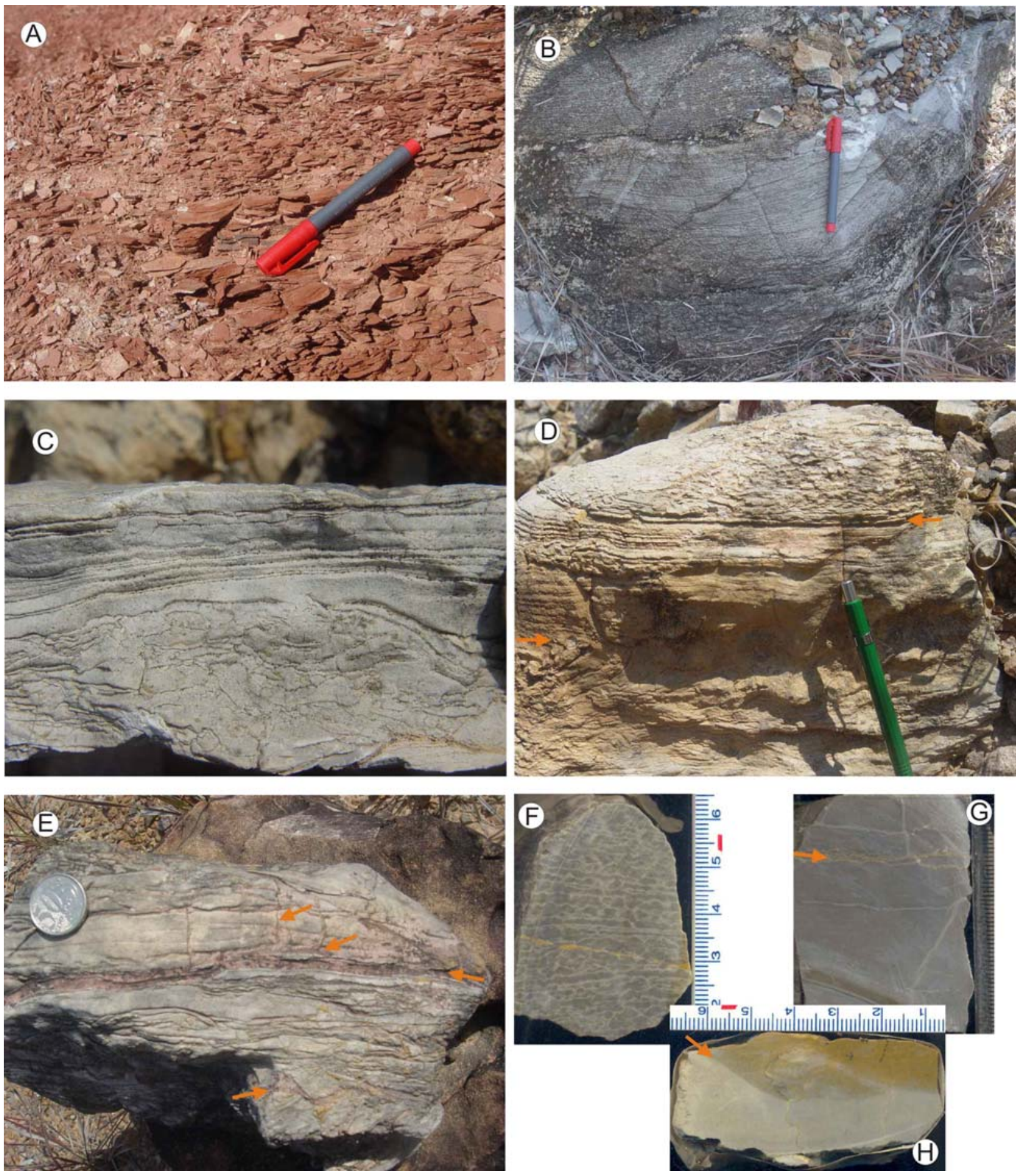

Figura 26. Fotos da Formação Serra Azul (Seção 8): (A) laminito vermelho; (B) mudstone laminado da base; (C) mudstone deformado por escorregamento seguido por mudstone laminado; (D) mudstone deformado por escorregamento, seguido por mudstone laminado e packestone de intraclastos; (E) mudstone mostrando deformação progressiva por compactação, como evidencia a lâmina de argila vermelha mais deformada na base e menos deformada no topo, onde as lâminas mais finas de argila e calcário encontram-se truncadas ou rompidas; (F) mudstone com lâminas deformadas por compactação evoluindo para textura nodular; $(\mathrm{G})$ mudstone maciço apresentando estilólitos; $(\mathrm{H})$ mudstone maciço apresentando estrutura de corte preenchida por wackestone com matriz impura na fração areia com alguns intraclastos. 
Tabela 4. Descrição petrográfica sucinta, com a classificação das amostras de rochas carbonáticas e sua possível interpretação.

\begin{tabular}{|c|c|c|c|c|}
\hline $\begin{array}{c}\text { Amos- } \\
\text { tra }\end{array}$ & $\begin{array}{l}\text { Unidade } \\
\text { Seção }\end{array}$ & Classificação & $\begin{array}{c}\text { Texturas } \\
\text { Estruturas }\end{array}$ & Figuras \\
\hline $19 \mathrm{C}$ & $\begin{array}{l}\text { Fm. S. Azul } \\
\text { Seção } 8\end{array}$ & Mudstone & $\begin{array}{c}\text { Desmicrita localizada, laminação } \\
\text { incipiente (1-3 mm), estilólito } \\
\text { freqüente. }\end{array}$ & $27 \mathrm{~A}$ \\
\hline 19D & $\begin{array}{l}\text { Fm. S. Azul } \\
\text { Seção } 8\end{array}$ & Mudstone & $\begin{array}{c}\text { Nodular, filmes de argila } \\
\text { deformados com feldspatização. }\end{array}$ & \\
\hline $19 \mathrm{E}$ & $\begin{array}{l}\text { Fm. S. Azul } \\
\text { Seção } 8\end{array}$ & Mudstone & $\begin{array}{l}\text { Deformação progressiva das } \\
\text { lâminas para o topo, passando a } \\
\text { nodular. }\end{array}$ & \\
\hline $19 \mathrm{~F}$ & $\begin{array}{l}\text { Fm. S. Azul } \\
\text { Seção } 8\end{array}$ & Mudstone & $\begin{array}{l}\text { Laminação cruzada sofrendo } \\
\text { desmicritização, seguida de } \\
\text { laminação plana }(2 \mathrm{~mm}) .\end{array}$ & \\
\hline $19 \mathrm{G}$ & $\begin{array}{l}\text { Fm. S. Azul } \\
\text { Seção } 8\end{array}$ & Mudstone & $\begin{array}{l}\text { Textura grumosa; laminação }(1,5 \\
\text { mm) com planos de recristalização } \\
\text { entre as lâminas. }\end{array}$ & \\
\hline $19 \mathrm{H}$ & $\begin{array}{l}\text { Fm. S. Azul } \\
\text { Seção } 8\end{array}$ & $\begin{array}{l}\text { Mudstone } \\
\text { Wackestone }\end{array}$ & $\begin{array}{l}\text { Micrita maciça com corte } \\
\text { preenchido por calcarenito impuro } \\
\text { com intraclastos. }\end{array}$ & \\
\hline 19I & $\begin{array}{l}\text { Fm. S. Azul } \\
\text { Seção } 8\end{array}$ & Mudstone & $\begin{array}{l}\text { Laminação truncada e ondulada } \\
\text { com lâmina intermediária dobrada } \\
\text { e falhada. }\end{array}$ & $27 \mathrm{~B}$ \\
\hline $43 \mathrm{~B}$ & $\begin{array}{l}\text { Fm. Guia } \\
\text { Seção } 1\end{array}$ & Mudstone & $\begin{array}{l}\text { Laminação incipiente rítmica, com } \\
\text { presença de matéria orgânica. }\end{array}$ & \\
\hline $43 \mathrm{C}$ & $\begin{array}{l}\text { Fm. Guia } \\
\text { Seção } 1\end{array}$ & Mudstone & $\begin{array}{c}\text { Laminação ondulada não paralela, } \\
\text { nódulos de chert preto } \\
\text { conservando calcário no seu } \\
\text { interior. }\end{array}$ & \\
\hline $43 \mathrm{D}$ & $\begin{array}{l}\text { Fm. Guia } \\
\text { Seção } 1\end{array}$ & Mudstone & $\begin{array}{l}\text { Laminação; ciclos } \\
\text { granodecrescentes. }\end{array}$ & \\
\hline $43 \mathrm{~F}$ & $\begin{array}{l}\text { Fm. Guia } \\
\text { Seção } 1\end{array}$ & Mudstone & $\begin{array}{l}\text { Maciça com impureza (terrígenos } \\
\text { na fração argila). }\end{array}$ & \\
\hline $43 \mathrm{G}$ & $\begin{array}{l}\text { Fm. Guia } \\
\text { Seção } 1\end{array}$ & Mudstone & $\begin{array}{l}\text { Laminação espessa }(0,6-2,5 \mathrm{~mm}) \\
\text { com filmes de matéria orgânica. }\end{array}$ & \\
\hline $43 \mathrm{H}$ & $\begin{array}{l}\text { Fm. Guia } \\
\text { Seção } 1\end{array}$ & Mudstone & $\begin{array}{l}\text { Laminação irregular produzida por } \\
\text { variação na cristalinidade } \\
\text { (desmicritização intensa). }\end{array}$ & \\
\hline $44 \mathrm{C}$ & $\begin{array}{l}\text { Fm. Guia } \\
\text { Seção } 2\end{array}$ & Mudstone & $\begin{array}{c}\text { Laminação rica em matéria } \\
\text { orgânica. }\end{array}$ & \\
\hline $44 \mathrm{D}$ & $\begin{array}{l}\text { Fm. Guia } \\
\text { Seção } 2\end{array}$ & Mudstone & $\begin{array}{l}\text { Laminação }(2 \mathrm{~mm}) \text { rítmica com } \\
\text { predomínio de lâminas ricas em } \\
\text { matéria orgânica e pirita. }\end{array}$ & \\
\hline $44 \mathrm{~F}$ & $\begin{array}{l}\text { Fm. Guia } \\
\text { Seção } 2\end{array}$ & Mudstone & $\begin{array}{l}\text { Contato estilolítico entre preto } \\
\text { laminado e cinza claro com } \\
\text { laminação ondulada incipiente } \\
\text { (biogênica?). }\end{array}$ & $28 \mathrm{~A}$ \\
\hline
\end{tabular}




\begin{tabular}{|c|c|c|c|c|}
\hline $\begin{array}{c}\text { Amos- } \\
\text { tra }\end{array}$ & $\begin{array}{l}\text { Unidade } \\
\text { Seção }\end{array}$ & Classificação & $\begin{array}{c}\text { Texturas } \\
\text { Estruturas }\end{array}$ & Possível ambiente \\
\hline $44 \mathrm{~K}$ & $\begin{array}{l}\text { Fm. Guia } \\
\text { Seção } 2\end{array}$ & Mudstone & $\begin{array}{l}\text { Laminação rítmica; lâminas mais } \\
\text { finas impuras e ricas em matéria } \\
\text { orgânica e pirita. }\end{array}$ & \\
\hline $44 \mathrm{I}$ & $\begin{array}{l}\text { Fm.Guia } \\
\text { Seção } 2\end{array}$ & $\begin{array}{l}\text { Packestone } \\
\text { Mudstone }\end{array}$ & $\begin{array}{l}\text { Brecha intraformacional (sismito?) } \\
\text { sobreposta por laminação rítmica. }\end{array}$ & $27 \mathrm{C}$ e $27 \mathrm{D}$ \\
\hline $44 \mathrm{~N}$ & $\begin{array}{l}\text { Fm. Guia } \\
\text { Seção } 2\end{array}$ & Mudstone & $\begin{array}{l}\text { Laminação rítmica }(2 \mathrm{~mm}) \text { e fino } \\
\text { estrato }(1,5 \mathrm{~cm}) \text { com nódulos de } \\
\text { chert preto. }\end{array}$ & $27 \mathrm{E}$ e $27 \mathrm{~F}$ \\
\hline $44 Q$ & $\begin{array}{l}\text { Fm. Guia } \\
\text { Seção } 2\end{array}$ & Mudstone & $\begin{array}{l}\text { Laminação rítmica, rica em } \\
\text { matéria orgânica. }\end{array}$ & \\
\hline $44 \mathrm{~T}$ & $\begin{array}{l}\text { Fm. Guia } \\
\text { Seção } 2\end{array}$ & Mudstone & $\begin{array}{l}\text { Laminação rítmica, com textura } \\
\text { grumosa e peloidal; pirita } \\
\text { associada à matéria orgânica } \\
\text { possivelmente produzida por } \\
\text { colônias de bactérias redutoras. }\end{array}$ & $28 \mathrm{~B}, 28 \mathrm{C}, 28 \mathrm{E}$ e $28 \mathrm{~F}$ \\
\hline $\begin{array}{l}44 \mathrm{~W} \\
F .28 D\end{array}$ & $\begin{array}{l}\text { Fm. Guia } \\
\text { Seção } 2\end{array}$ & Mudstone & $\begin{array}{c}\text { Laminação irregular e truncada por } \\
\text { estilolitização e falhada, sobreposta } \\
\text { por ondulações simétricas } \\
\text { (hummocky?) }\end{array}$ & $28 \mathrm{D}$ \\
\hline $45 \mathrm{~A}$ & $\begin{array}{l}\text { Fm. Guia } \\
\text { Seção } 2\end{array}$ & Mudstone & Laminação rítmica. & \\
\hline $45 \mathrm{~B}$ & $\begin{array}{l}\text { Fm. Guia } \\
\text { Seção } 2\end{array}$ & Mudstone & $\begin{array}{l}\text { Laminação ondulada sobreposta } \\
\text { por laminação plana rica em mat. } \\
\text { orgânica, micro silicificação } \\
\text { pontual. }\end{array}$ & \\
\hline $45 \mathrm{E}$ & $\begin{array}{l}\text { Fm. Guia } \\
\text { Seção } 2\end{array}$ & $\begin{array}{l}\text { Mudstone } \\
\text { Wackestone }\end{array}$ & $\begin{array}{l}\text { Laminação rítmica sobreposta por } \\
\text { brecha recoberta por nova } \\
\text { laminação rítmica (turbidito?) em } \\
\text { ciclo granodecrescente. }\end{array}$ & \\
\hline $45 \mathrm{G}$ & $\begin{array}{l}\text { Fm. Guia } \\
\text { Seção } 2\end{array}$ & Mudstone & $\begin{array}{l}\text { Laminação rítmica, veios } \\
\text { irregulares preenchidos por micrita } \\
\text { (escape de fluído). }\end{array}$ & \\
\hline $45 \mathrm{~J}$ & $\begin{array}{l}\text { Fm. Guia } \\
\text { Seção } 2\end{array}$ & Mudstone & Laminação rítmica. & \\
\hline $45 \mathrm{M}$ & $\begin{array}{l}\text { Fm. Guia } \\
\text { Seção } 2\end{array}$ & Mudstone & $\begin{array}{l}\text { Laminação ondulada com } \\
\text { microssilicificação pontual. }\end{array}$ & $29 \mathrm{~A}$ \\
\hline $45 \mathrm{P}$ & $\begin{array}{l}\text { Fm. Guia } \\
\text { Seção } 2\end{array}$ & Mudstone & Laminação rítmica. & \\
\hline $45 \mathrm{~S}$ & $\begin{array}{l}\text { Fm. Guia } \\
\text { Seção } 2\end{array}$ & $\begin{array}{l}\text { Mudstone } \\
\text { Packestone }\end{array}$ & $\begin{array}{l}\text { Laminação truncada sobreposta } \\
\text { por brecha granocrescente, com } \\
\text { contato deformado plasticamente. }\end{array}$ & \\
\hline $45 \mathrm{~V}$ & $\begin{array}{l}\text { Fm. Guia } \\
\text { Seção } 2\end{array}$ & Mudstone & $\begin{array}{l}\text { Laminação com nível apresentando } \\
\text { laminação dobrada e falhada. }\end{array}$ & \\
\hline $45 Z$ & $\begin{array}{l}\text { Fm. Guia } \\
\text { Seção } 2\end{array}$ & Packestone & $\begin{array}{l}\text { Brecha suportada por intraclastos } \\
\text { alongados paralelos ao } \\
\text { acamamento e matriz micrítica. }\end{array}$ & \\
\hline 46 & $\begin{array}{l}\text { Fm. Guia } \\
\text { Seção } 3\end{array}$ & Mudstone & $\begin{array}{c}\text { Laminação rompida e falhada } \\
\text { sobreposta por laminação espessa } \\
\text { contínua. }\end{array}$ & \\
\hline
\end{tabular}




\begin{tabular}{|c|c|c|c|c|}
\hline $\begin{array}{c}\text { Amos- } \\
\text { tra }\end{array}$ & $\begin{array}{l}\text { Unidade } \\
\text { Seção }\end{array}$ & Classificação & $\begin{array}{c}\text { Texturas } \\
\text { Estruturas }\end{array}$ & Possível ambiente \\
\hline $50 \mathrm{~B}$ & $\begin{array}{l}\text { Fm. Guia } \\
\text { Seção } 3\end{array}$ & Mudstone & $\begin{array}{c}\text { Estratificação estreita rítmica com } \\
\text { lâminas ricas em matéria orgânica } \\
\text { no topo de cada par. }\end{array}$ & 29B \\
\hline 54 & $\begin{array}{l}\text { Fm. Nobres } \\
\text { Seção } 3\end{array}$ & Dolomudstone & $\begin{array}{l}\text { Laminação rítmica dolomitizada, } \\
\text { com porosidade secundária. }\end{array}$ & $29 \mathrm{C}$ \\
\hline 58 & $\begin{array}{l}\text { Fm. Nobres } \\
\text { Seção } 3\end{array}$ & Mudstone & $\begin{array}{c}\text { Laminação rítmica } \\
\text { granodecrescente rica em Mg e Fe, } \\
\text { com microssilicificação pontual. }\end{array}$ & \\
\hline 62 & $\begin{array}{l}\text { Fm. Nobres } \\
\text { Seção } 3\end{array}$ & Mudstone & Laminação rítmica. & \\
\hline $64^{*}$ & $\begin{array}{l}\text { Fm. Nobres } \\
\text { Seção } 3\end{array}$ & Mudstone & $\begin{array}{c}\text { Estratificação estreita dobrada } \\
\text { sobreposta por laminação irregular } \\
\text { quase paralela. }\end{array}$ & \\
\hline 65 & $\begin{array}{l}\text { Fm. Nobres } \\
\text { Seção } 3\end{array}$ & Dolomudstone & Laminação plana rica em Fe. & \\
\hline 69 & $\begin{array}{l}\text { Fm. Nobres } \\
\text { Seção } 3\end{array}$ & $\begin{array}{l}\text { Dolomito } \\
\text { cristalino }\end{array}$ & $\begin{array}{l}\text { Maciço com alguns fantasmas de } \\
\text { laminação, porosidade secundária. }\end{array}$ & \\
\hline 77 & $\begin{array}{l}\text { Fm. Nobres } \\
\text { Seção } 3\end{array}$ & $\begin{array}{l}\text { Dolomito } \\
\text { cristalino }\end{array}$ & Maciço, porosidade secundária. & \\
\hline 82 & $\begin{array}{l}\text { Fm. Nobres } \\
\text { Seção } 3\end{array}$ & Dolopackestone & Brecha maciça. & \\
\hline 86 & $\begin{array}{l}\text { Fm. Nobres } \\
\text { Seção } 3\end{array}$ & $\begin{array}{l}\text { Dolomito } \\
\text { cristalino }\end{array}$ & Maciço, porosidade secundária. & \\
\hline 90 & $\begin{array}{l}\text { Fm. Nobres } \\
\text { Seção } 3\end{array}$ & Dolograinstone & $\begin{array}{c}\text { Intraclastos alongados paralelos ao } \\
\text { acamamento, peloidal e oncolítico, } \\
\text { porosidade secundária. }\end{array}$ & $29 \mathrm{D}$ e $29 \mathrm{E}$ \\
\hline 94 & $\begin{array}{l}\text { Fm. Nobres } \\
\text { Seção } 3\end{array}$ & $\begin{array}{l}\text { Dolomito } \\
\text { cristalino }\end{array}$ & Maciça impura. & \\
\hline 97 & $\begin{array}{l}\text { Fm. Nobres } \\
\text { Seção } 3\end{array}$ & Dolowackestone & $\begin{array}{c}\text { Laminação plano paralela seguida } \\
\text { de laminação cruzada tipo } \\
\text { climbing, na fração areia fina, } \\
\text { muito impura. }\end{array}$ & $29 \mathrm{~F}$ \\
\hline 98 & $\begin{array}{l}\text { Fm. Nobres } \\
\text { Seção } 3\end{array}$ & Dolomudstone & Maciço. & $30 \mathrm{~A}$ \\
\hline 99 & $\begin{array}{l}\text { Fm. Nobres } \\
\text { Seção } 3\end{array}$ & $\begin{array}{l}\text { Dolowackestone } \\
\text { Dolomudstone }\end{array}$ & $\begin{array}{c}\text { Acamamento granodecrescente, } \\
\text { com intraclastos na base e lama no } \\
\text { topo. }\end{array}$ & $30 \mathrm{~B}$ \\
\hline 100 & $\begin{array}{l}\text { Fm. Nobres } \\
\text { Seção } 3\end{array}$ & $\begin{array}{l}\text { Dolograinstone } \\
\text { Dolomudstone }\end{array}$ & $\begin{array}{c}\text { Alternância de estreitas camadas } \\
\text { maciças e oncolíticas com } \\
\text { intraclastos e porosidade tipo } \\
\text { vuggy. }\end{array}$ & $30 \mathrm{C}$ e $30 \mathrm{D}$ \\
\hline 101 & $\begin{array}{l}\text { Fm. Nobres } \\
\text { Seção } 3\end{array}$ & Dolograinstone & $\begin{array}{l}\text { Camada granodecrescente de } \\
\text { oncólitos, intraclastos e porosidade } \\
\text { fenestral. }\end{array}$ & $30 \mathrm{E}$ e $30 \mathrm{~F}$ \\
\hline
\end{tabular}



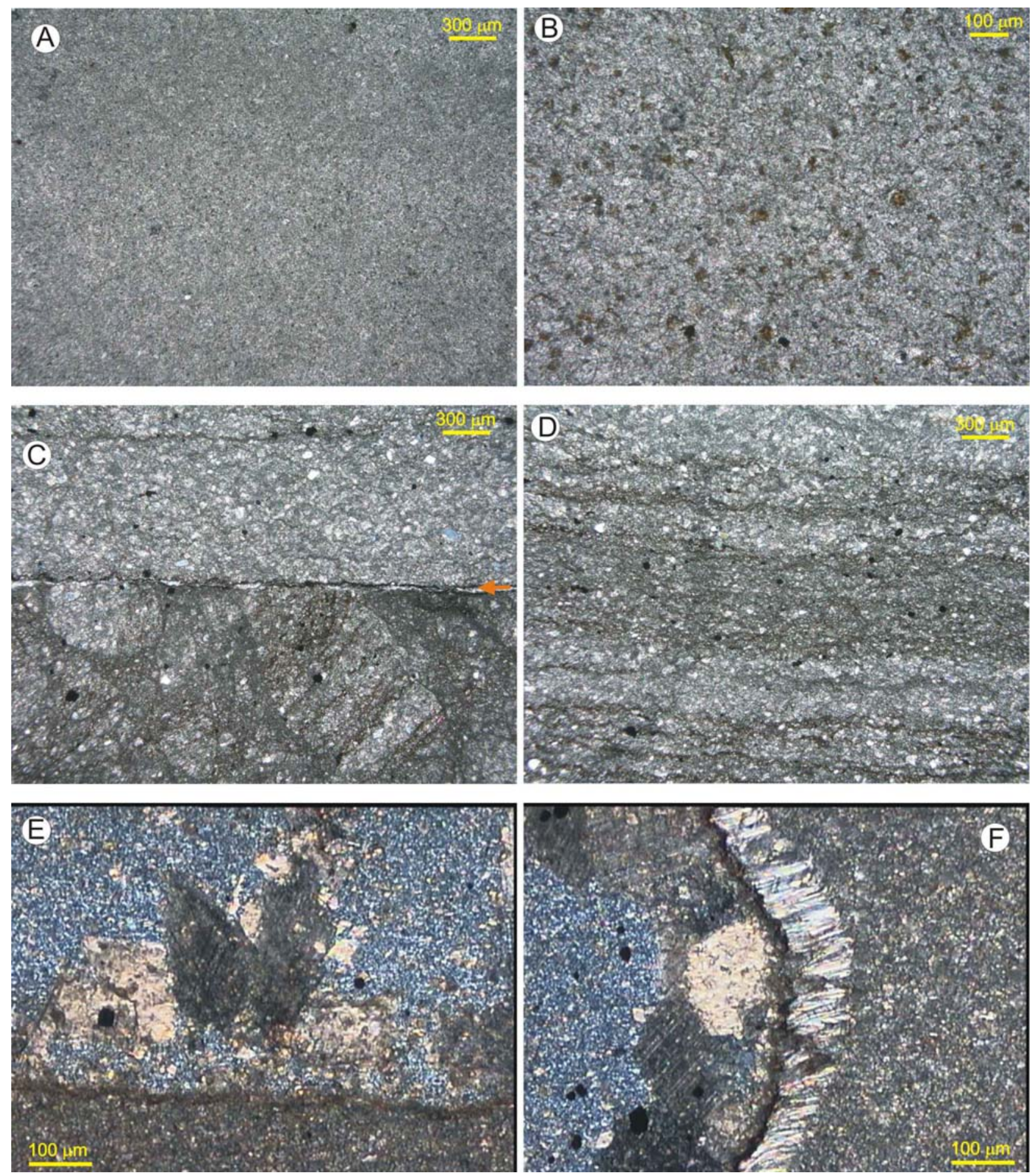

Figura 27. Fotomicrografia dos carbonatos estudados, nicóis cruzados: (A) exemplo de mudstone da Seção 8; (B) detalhe de outro mudstone da mesma seção; (C) packestone de ritmito brechado sotoposto a ritmito mostrado na foto (D) em contato plano erosivo, Seção 2; (E) detalhe do contato inferior entre nódulo de chert (em cinza, acima) ocorrente na base da Seção 2 e mudstone rico em matéria orgânica (abaixo), com calcita espática euédrica crescendo da borda para o centro do chert; (F) detalhe do contato lateral entre mesmo nódulo de chert (em cinza a esquerda) e mudstone (direita), o contato é irregular e marcado pela presença de calcita espática anédrica passando a calcita fibrosa. 

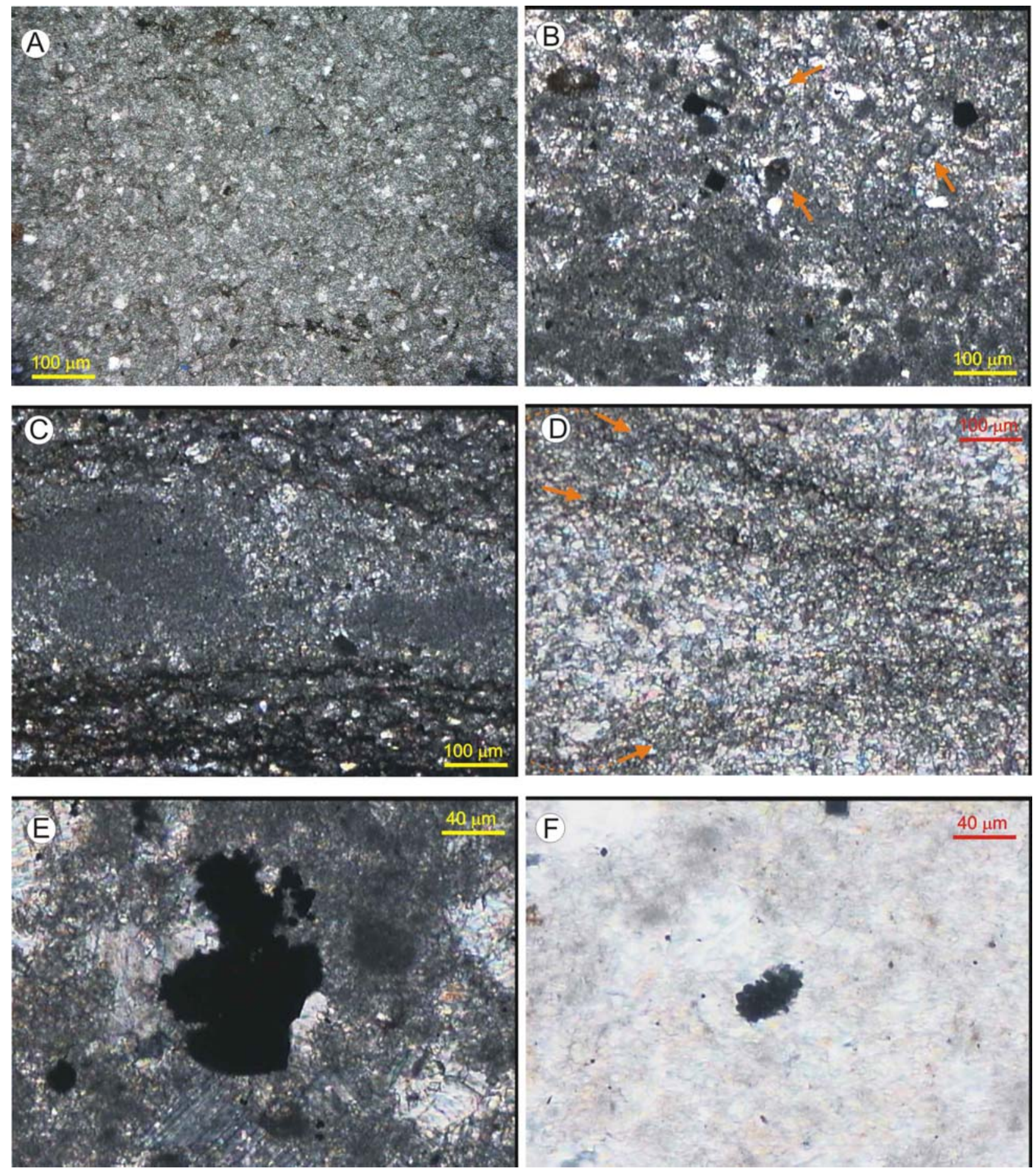

Figura 28. Fotomicrografia dos carbonatos estudados, nicóis cruzados: (A) mudstone da Seção 1; (B) textura peloidal rica em matéria orgânica, apresentando grande quantidade de pirita e pequenas esferas que lembram pequenas algas e esfera com morfologia trilateral, possível microfóssil, Seção 2; (C) textura grumosa nas lâminas mais claras da mesma amostra; (D) ondulações simétricas, Seção 2; (E) pirita envolvida por aglomerados que lembram colônia de bactérias redutoras, predominantemente associada aos níveis ricos em matéria orgânica; $(\mathrm{F})$ detalhe de possível colônia de bactérias redutoras na mesma amostra, com luz condensada. 

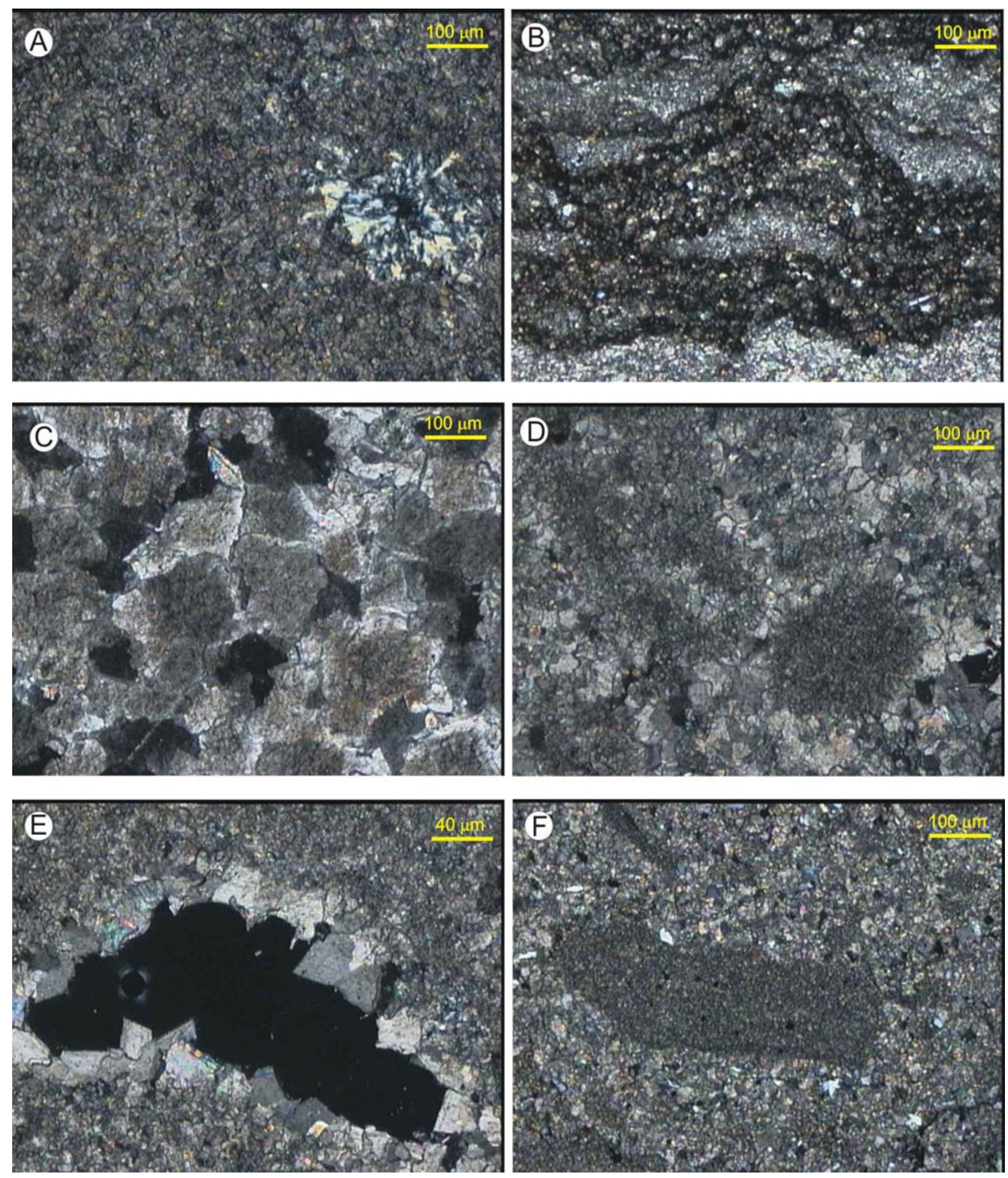

Figura 29. Fotomicrografia dos carbonatos estudados, nicóis cruzados: (A) silicificação pontual de mudstone em micronódulos radiais, Seção 2; (B) laminação rica em matéria orgânica arqueada, Seção 3; (C) exemplo de dolomito cristalino, mostrando cristais grandes de dolomita anédrica, Seção 3; (D) grainstone de intraclastos e pellets micritizados, cimentados por calcita espática, Seção 3; (E) detalhe de porosidade secundária; (F) intraclastos preenchendo estrutura de corte na base de uma seqüência turbidítica, Seção 3. 

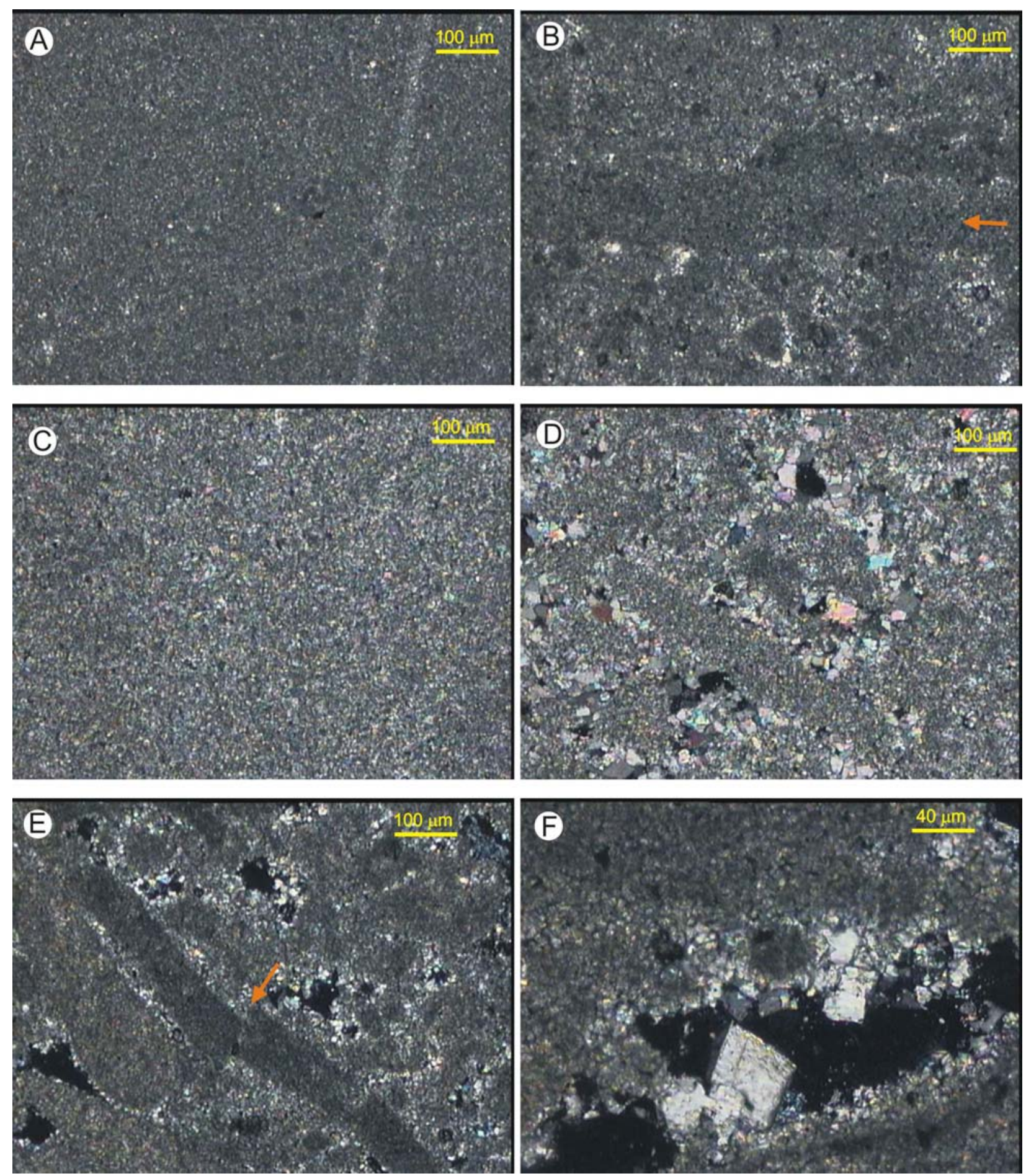

Figura 30. Fotomicrografia dos carbonatos estudados, nicóis cruzados: (A) dolomudstone maciço, Seção 3; (B) textura peloidal com estreita lâmina possivelmente biogênica, Seção 3; (C) dolomudstone, intercalado a dolograinstone de intraclastos e oncólitos micritizados, cimentados por calcita espática, mostrado na foto (D); (E) dolograinstone com detalhe de fraturamento de intraclasto alongado durante compactação, Seção3; (F) detalhe de porosidade fenestral de (E). 


\subsection{ANÁLISE QUÍMICA}

Os resultados das análises geoquímicas realizadas nos carbonatos estão demonstrados na Tabela 5, estando indicados a seção de que fazem parte e o número da respectiva amostra, que pode ser conferido na coluna estratigráfica do item V.1 (Figura 18). Os carbonatos foram classificados quimicamente com base na razão $\mathrm{Mg} / \mathrm{Ca}$. Adotaram-se os limites $(\mathrm{Mg} / \mathrm{Ca}) \mathrm{de}$ classificação: calcário ( 0 a 0,02$)$, calcário magnesiano $(0,02$ a 0,08$)$, calcário dolomítico $(0,08$ a $0,25)$, dolomito calcítico $(0,25$ a 0,56$)$ e dolomito $(>0,56)$.

É possível observar que as seções 1 e 2, correspondentes à Formação Guia, são predominantemente calcáreas com variações no conteúdo de $\mathrm{Mg}$. A seção 3 , correspondente à Formação Nobres, possui uma composição predominantemente dolomítica, com exceção das primeiras amostras que são pertencentes à Formação Guia, mostrando uma transição química não brusca entre estas duas formações do Grupo Araras. As amostras coletadas na seção 8, Formação Serra Azul, são compostas basicamente de calcários, claramente desprovidas de termos magnesianos.

Foram empregados parâmetros de avaliação da alteração das amostras tais como a razão $\mathrm{Mn} / \mathrm{Sr}$ e $\mathrm{Rb} / \mathrm{Sr}$. A razão $\mathrm{Mn} / \mathrm{Sr}$ é muito utilizada como um critério para detecção de alteração diagenética, pois fluidos não marinhos, como água doce ou meteórica, costumam conter mais Mn e menos Sr que a água do mar. Assim, a percolação de fluídos não marinhos tende a aumentar a razão $\mathrm{Mn} / \mathrm{Sr}$ original. Neste estudo foram aceitas como inalteradas as amostras com razão menor que 2, conforme proposto por Veizer (1983) e seguido por outros pesquisadores (Derry et al., 1992; Kaufman et al., 1992 e 1993; Jacobsen \& Kaufman, 1999). Noentanto, Kaufman \& Knoll (1995) foram menos rigorosos e adotaram razões Mn/Sr menores que 10, pois o volume de água meteórica que facilmente alteraria as razões $\mathrm{Mn} / \mathrm{Sr}$ pode não afetar a composição de elementos maiores, comumente mantendo as razões isotópicas primárias de C.

Todas as amostras analisadas (Tabela 6) possuem uma razão $\mathrm{Mn} / \mathrm{Sr}$ abaixo de 2, indicando que as mesmas não sofreram alteração diagenética por grandes volumes de fluídos não marinhos. Isso garante uma boa qualidade das amostras para a realização de análises isotópicas de $\mathrm{C}$ e O.

A razão $\mathrm{Rb} / \mathrm{Sr}$ fornece uma indicação da presença de fases clásticas ricas em $\mathrm{Rb}$, como as micas, que por decaimento radioativo adicionariam $\mathrm{Sr}$ radiogênico aos carbonatos, alterando as razões isotópicas primárias, conseqüentemente resultando em razões ${ }^{87} \mathrm{Sr} /{ }^{86} \mathrm{Sr}$ mais altas. Para este trabalho foram aceitas como inalteradas a muito pouco alteradas as razões $\mathrm{Rb} / \mathrm{Sr}$ menores 
que 0,008, sendo que Derry et al. (1989) sugeriram 0,005 como inalteradas. Os dados adquiridos mostram que as razões $\mathrm{Rb} / \mathrm{Sr}$ mais altas estão associadas ao dolomitos e aos termos mais magnesianos, enquanto que as mais baixas se associam aos calcários. Isso pode indicar uma maior quantidade de terrígenos associados ao dolomitos com mais alto teor de $\mathrm{Rb}$ ou simplesmente a pouca afinidade da dolomita com o $\mathrm{Sr}$, que é facilmente retido pela calcita devido à semelhança de seu raio iônico com o do Ca.

\subsection{QUIMIOESTRATIGRAFIA}

Seguem-se os dados obtidos e uma breve descrição desses valores pertencentes a cada seção litoestratigráfica analisada (Tabela 6 e Figura 31).

\subsubsection{Seção 1}

Para esta seção foram analisadas 6 amostras de calcários (Tabela 6, Figura 31A), todas pertencentes à Formação Guia. As análises apresentaram valores de $\delta^{13} \mathrm{C}$ levemente negativos, variando entre - 0,76 e - 0,08 \%o, sendo que os valores mais negativos encontram-se na base da seqüência. As análises petrográfica e química demonstraram que as amostras não sofreram alterações pós-deposicionais, em função das suas baixas razões $\mathrm{Mn} / \mathrm{Sr}(<0,15), \mathrm{Fe} / \mathrm{Sr}(<0,4)$ e $\mathrm{Rb} / \mathrm{Sr}(<0,006)$ (Tabela 6). No entanto estão presentes estilólitos, comuns a calcários, que foram devidamente evitados no microdrilling. A composição isotópica de $\delta^{18} \mathrm{O}$ varia entre $-8,4 \mathrm{e}-7,4$ \%, sem correlação com a razão $\mathrm{Mg} / \mathrm{Ca}$ (Figura 33A). Duas amostras desta seção, uma próxima à base e outra próxima ao topo, foram analisadas para ${ }^{87} \mathrm{Sr} /{ }^{86} \mathrm{Sr}$, apresentando valores isotópicos de 0,70747 e 0,70779, respectivamente. As composições isotópicas de $\mathrm{Sr}$ parecem refletir a composição original da água do mar, pelo fato de apresentarem baixas razões de $\mathrm{Rb} / \mathrm{Sr}$ (acima) e alta concentração de $\operatorname{Sr}(525,7$ e 1261,8 ppm), comum aos calcários. 
Tabela 5. Resultados das análises químicas obtidos nos carbonatos do Grupo Araras e da Formação Serra Azul. As seções estratigráficas correspondentes estão indicadas à esquerda (S1, S2, S3 e S8). Os campos marcados com * indicam resultados em fase de obtenção.

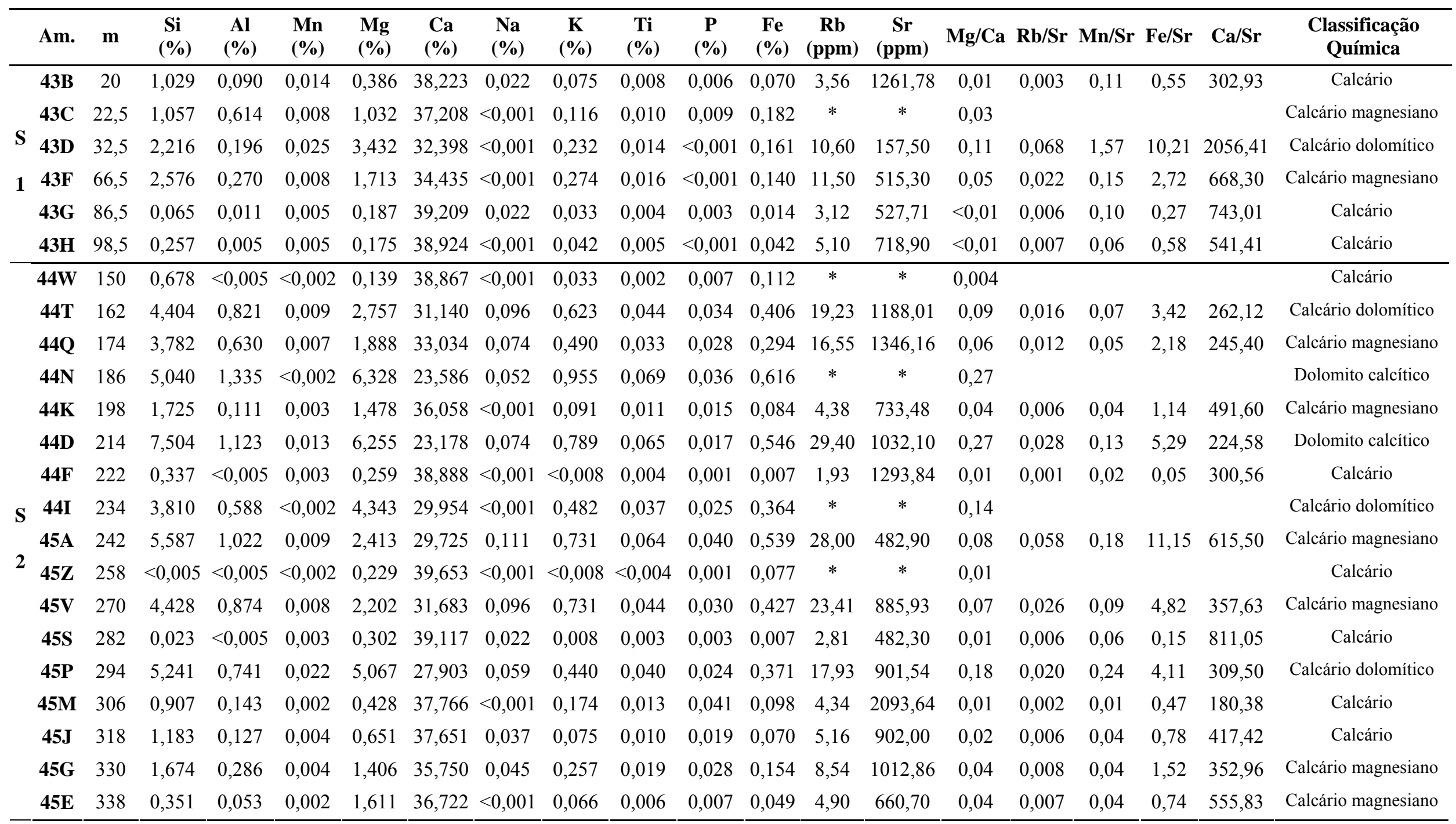




\begin{tabular}{|c|c|c|c|c|c|c|c|c|c|c|c|c|c|c|c|c|c|c|c|c|}
\hline & Am. & m & $\begin{array}{l}\mathrm{Si} \\
(\%)\end{array}$ & $\begin{array}{c}\text { Al } \\
(\%)\end{array}$ & $\begin{array}{l}\text { Mn } \\
(\%)\end{array}$ & $\begin{array}{l}\text { Mg } \\
(\%)\end{array}$ & $\begin{array}{c}\text { Ca } \\
(\%)\end{array}$ & $\begin{array}{l}\mathrm{Na} \\
(\%)\end{array}$ & $\begin{array}{c}K \\
(\%)\end{array}$ & $\begin{array}{c}\mathrm{Ti} \\
(\%)\end{array}$ & $\begin{array}{c}P \\
(\%)\end{array}$ & $\begin{array}{c}\mathrm{Fe} \\
(\%)\end{array}$ & $\begin{array}{c}\text { Rb } \\
(\mathbf{p p m})\end{array}$ & $\begin{array}{c}\mathrm{Sr} \\
(\mathrm{ppm})\end{array}$ & $\mathrm{Mg} / \mathrm{Ca}$ & $\mathrm{Rb} / \mathrm{Sr}$ & $\mathrm{Mn} / \mathrm{Sr}$ & $\mathrm{Fe} / \mathrm{Sr}$ & $\mathrm{Ca} / \mathrm{Sr}$ & $\begin{array}{c}\text { Classificação } \\
\text { Química }\end{array}$ \\
\hline \multirow[b]{9}{*}{$\mathbf{S}$} & 46 & 434 & 1,370 & 0,185 & 0,004 & 1,104 & 36,594 & 0,045 & 0,216 & 0,012 & 0,024 & 0,098 & 6,99 & 797,69 & 0,03 & 0,009 & 0,05 & 1,23 & 458,75 & Calcário magnesiano \\
\hline & $50 \mathrm{~B}$ & 474 & 1,501 & 0,254 & 0,003 & 3,010 & 34,085 & 0,059 & 0,191 & 0,015 & 0,034 & 0,112 & 5,61 & 1262,35 & 0,09 & 0,004 & 0,02 & 0,89 & 270,01 & Calcário dolomítico \\
\hline & 54 & 514 & $<0,005$ & $<0,005$ & 0,002 & 13,434 & 22,392 & $<0,001$ & 0,008 & 0,004 & 0,014 & 0,007 & 1,52 & 50,20 & 0,60 & 0,030 & 0,31 & 1,39 & 4460,68 & Dolomito \\
\hline & 58 & 554 & 1,622 & 0,175 & 0,003 & 13,174 & 21,170 & $<0,001$ & 0,166 & 0,013 & 0,022 & 0,091 & 4,83 & 43,65 & 0,62 & 0,111 & 0,71 & 20,83 & 4849,49 & Dolomito \\
\hline & 62 & 588 & 0,575 & 0,090 & 0,002 & 0,959 & 37,837 & $<0,001$ & 0,125 & 0,009 & 0,014 & 0,042 & 4,89 & 635,93 & 0,03 & 0,008 & 0,04 & 0,66 & 594,99 & Calcário magnesiano \\
\hline & 64 & 678 & 0,238 & 0,021 & 0,003 & 0,446 & 38,516 & $<0,001$ & 0,050 & 0,005 & $<0,001$ & 0,021 & 7,80 & 862,00 & 0,01 & 0,009 & 0,04 & 0,24 & 446,83 & Calcário \\
\hline & 65 & 688 & 0,351 & 0,037 & 0,002 & 13,645 & 21,985 & $<0,001$ & 0,050 & 0,006 & 0,010 & 0,028 & 2,50 & 36,19 & 0,62 & 0,069 & 0,43 & 7,73 & 6075,49 & Dolomito \\
\hline & 69 & 728 & 0,309 & $<0,005$ & 0,002 & 13,741 & 21,856 & $<0,001$ & $<0,008$ & 0,004 & 0,001 & 0,007 & 0,84 & 36,45 & 63 & 23 & 0,42 & 1,92 & 59 & Dolomito \\
\hline & 77 & 808 & $<0,005$ & $<0,005$ & 0,002 & 13,844 & 22,028 & $<0,001$ & $<0,008$ & $<0,004$ & $<0,001$ & 0,014 & 0,70 & 43,40 & 0,63 & 0,016 & 0,54 & 3,23 & 5078,42 & Dolomito \\
\hline \multirow[t]{9}{*}{3} & 82 & 908 & 0,094 & $<0,005$ & 0,002 & 13,663 & 22,192 & $<0,001$ & $<0,008$ & 0,004 & 0,010 & 0,014 & 1,47 & 79,45 & 0,62 & 0,019 & 0,29 & 1,76 & 2793,17 & to \\
\hline & 86 & 988 & 0,196 & $<0,005$ & 0,002 & 13,717 & 21,820 & $<0,001$ & $<0,008$ & $<0,004$ & $<0,001$ & 0,007 & 0,40 & 28,90 & 0,63 & 0,013 & 0,54 & 2,42 & 7549,13 & Dolomito \\
\hline & 90 & 1068 & 2,688 & $<0,005$ & 0,002 & 12,855 & 20,834 & $<0,001$ & $<0,008$ & 0,005 & 0,031 & 0,007 & 1,12 & 51,84 & 0,62 & 0,022 & 0,30 & 1,35 & 4018,68 & Dolomito \\
\hline & 94 & 1226 & 0,514 & 0,053 & 0,005 & 13,723 & 21,299 & $<0,001$ & 0,108 & 0,005 & $<0,001$ & 0,063 & 3,40 & 87,20 & 0,64 & 0,039 & 0,62 & 7,22 & 2442,92 & Dolomito \\
\hline & 97 & 1286 & 10,590 & 1,451 & 0,009 & 9,875 & 15,552 & 0,015 & 1,594 & 0,054 & 0,017 & 0,168 & 35,45 & 77,71 & 0,63 & 0,456 & 1,20 & 21,61 & 2001,45 & Dolomito \\
\hline & 98 & 1306 & 0,182 & 0,021 & 0,005 & 13,561 & 21,749 & $<0,001$ & 0,017 & 0,004 & $<0,001$ & 0,063 & 2,10 & 73,50 & 0,62 & 0,029 & 0,63 & 8,56 & 2958,53 & nito \\
\hline & 99 & 1326 & 0,075 & $<0,005$ & 0,003 & 13,681 & 22,049 & $<0,001$ & 0,008 & 0,006 & 0,004 & 0,021 & 1,73 & 76,39 & 0,62 & 0,023 & 0,41 & 2,75 & 2886,35 & Dolomito \\
\hline & 100 & 1346 & $<0,005$ & $<0,005$ & 0,004 & 13,754 & 21,863 & $<0,001$ & $<0,008$ & $<0,004$ & $<0,001$ & 0,021 & 2,10 & 75,30 & 0,63 & 0,027 & 0,51 & 2,79 & 2904,64 & Dolomito \\
\hline & 101 & 1366 & $<0,005$ & $<0,005$ & 0,003 & 13,856 & 22,078 & $<0,001$ & $<0,008$ & $<0,004$ & 0,020 & 0,021 & 1,21 & 87,28 & 0,63 & 0,014 & 0,36 & 2,40 & 2529,51 & Dolomito \\
\hline \multirow{7}{*}{$S$} & $19 I$ & 1684 & 0,912 & 0,207 & 0,020 & 0,259 & 37,809 & $<0,001$ & 0,166 & 0,016 & $<0,001$ & 0,203 & 9,10 & 547,80 & 0,01 & 0,017 & 0,37 & 3,70 & 690,13 & Calcário \\
\hline & $19 H$ & 1686 & 2,179 & 0,498 & 0,014 & 0,277 & 36,701 & 0,052 & 0,349 & 0,028 & 0,008 & 0,273 & 13,52 & 1152,24 & 0,01 & 0,012 & 0,12 & 2,37 & 318,52 & Calcário \\
\hline & 19G & 1687 & 1,678 & 0,413 & 0,018 & 0,187 & 36,915 & $<0,001$ & 0,307 & 0,025 & $<0,001$ & 0,266 & 13,60 & 884,90 & 0,01 & 0,015 & 0,20 & 3,00 & 417,19 & Calcário \\
\hline & $19 F$ & 1689 & 1,211 & 0,164 & 0,014 & 0,103 & 38,366 & $<0,001$ & 0,141 & 0,010 & 0,007 & 0,119 & 6,25 & 376,28 & $<0,01$ & 0,017 & 0,37 & 3,16 & 1019,61 & Calcário \\
\hline & $19 E$ & 1691 & 1,005 & 0,180 & 0,007 & 0,133 & 38,145 & $<0,001$ & 0,158 & 0,013 & $<0,001$ & 0,119 & 8,50 & 820,30 & $<0,01$ & 0,010 & 0,09 & 1,45 & 464,99 & Calcário \\
\hline & 19D & 1692 & 0,912 & 0,159 & 0,016 & 0,127 & 38,237 & 0,030 & 0,133 & 0,011 & 0,006 & 0,112 & 4,64 & 744,46 & $<0,01$ & 0,006 & 0,22 & 1,50 & 513,62 & Calcário \\
\hline & $19 \mathrm{C}$ & 1696 & 0,262 & 0,058 & 0,005 & 0,109 & 39,388 & 0,022 & 0,058 & 0,007 & 0,006 & 0,042 & 3,53 & 741,36 & $<0,01$ & 0,005 & 0,06 & 0,57 & 531,30 & Calcário \\
\hline
\end{tabular}




\subsubsection{Seção 2}

Foram realizadas análises isotópicas em 17 amostras desta seção (Tabela 6, Figura 31B), todas pertencentes à Formação Guia, com valores $\delta^{13} \mathrm{C}$ entre $0,03 \mathrm{e}-1,70 \%$, sendo que, dentro deste intervalo, os valores maiores que $-1 \%$ estão nos primeiros $92 \mathrm{~m}$ e os valores menores que $-1 \%$ estão nos $96 \mathrm{~m}$ subseqüentes (Figura 31 ). Os valores de $\delta^{18} \mathrm{O}$ obtidos variam de $-6,5 \mathrm{a}-$ 8,8 \% , no mesmo intervalo dos valores de $\delta^{13} \mathrm{C}$; os valores maiores que $-7,4 \%$ situam-se na primeira metade da seção, enquanto os menores que - 7,4 \%o estão na metade superior, não havendo correlação com as razões $\mathrm{Mg} / \mathrm{Ca}$ (Figura 33A). Os calcários deste intervalo aparentemente não sofreram alteração por processos pós-deposicionais, como se observa nas baixas razões $\mathrm{Mn} / \mathrm{Sr}$ menores que 0,12 (Figura 32), exceto uma camada de dolomito calcífero laminado com razão $\mathrm{Mn} / \mathrm{Sr}$ de 0,31 , ainda assim não muito alta e dentro dos padrões aceitáveis. As razões $\mathrm{Fe} / \mathrm{Sr}$ variam $(0,04$ a 3,44) conforme aumenta o conteúdo de sílica $(0,05$ a 11,21\%), certamente como reflexo de conteúdo terrígeno, em algumas amostras, ainda que baixo. Desta seção, cinco amostras (com razões $\mathrm{Rb} / \mathrm{Sr}<0,008$ ) foram analisadas para ${ }^{87} \mathrm{Sr} /{ }^{86} \mathrm{Sr}$, obtendo-se razões oscilando entorno de 0,7077 , ao longo da seqüência.

\subsubsection{Seção 3}

Para esta seção foram selecionadas 18 amostras para análise isotópica de C e O (Tabela 6, Figura 31C), na maioria dolomitos da Formação Nobres. Os resultados de $\delta^{13} \mathrm{C}$ variam entre 1,34 e 3,97 \%o. Os valores negativos (-1,34 a -0,48\%o) encontram-se nos primeiros $380 \mathrm{~m}$ da seção, valores próximos de zero $(0,09$ a $0,15 \%$ ) na porção intermediária, entre 380 a 580 m, e valores positivos de 0,43 a 3,97 \% com forte oscilação próxima ao topo (nos $150 \mathrm{~m}$ finais). Os valores de $\delta^{18} \mathrm{O}$ oscilam entre $-3,2 \mathrm{e}-8,3 \%$, sem correlação com a razão $\mathrm{Mg} / \mathrm{Ca}$ (Figura 33A). Os calcários apresentam razões $\mathrm{Mn} / \mathrm{Sr}$ inferiores a 0,063 (Figura 18) e Rb/Sr menores que 0,009, enquanto que nos dolomitos essas razões aumentam $(\mathrm{Mn} / \mathrm{Sr}$ entre 0,40 e 0,92 e $\mathrm{Rb} / \mathrm{Sr}$ entre 0,01 e 0,11 ), mostrando possível alteração diagenética, não muito intensa, talvez devido ao processo de dolomitização de alguns carbonatos. Para análises isotópicas de $\mathrm{Sr}$ foram selecionadas 3 amostras de calcário (apenas da base da seqüência) com razões $\mathrm{Rb} / \mathrm{Sr}<0,009$, que forneceram razões ${ }^{87} \mathrm{Sr} /{ }^{86} \mathrm{Sr}$ variando entre 0,70763 e 0,70779 (continuando o padrão oscilatório observado na seção anterior). 
Tabela 6. Resultados das análises isotópicas nos carbonatos do Grupo Araras e da Formação Serra Azul.

\begin{tabular}{|c|c|c|c|c|c|c|c|c|c|c|c|}
\hline & Am. & $\mathbf{m}$ & $\mathrm{Mg} / \mathrm{Ca}$ & $\mathbf{R b} / \mathbf{S r}$ & $\mathrm{Mn} / \mathrm{Sr}$ & $\mathrm{Fe} / \mathrm{Sr}$ & $\mathrm{Ca} / \mathrm{Sr}$ & $\delta^{13} \mathrm{C}$ & $\delta^{18} O$ & ${ }^{87} \mathrm{Sr} /{ }^{86} \mathrm{Sr}$ & Rocha analisada \\
\hline \multirow{3}{*}{$\mathbf{S}$} & 43B & 20 & 0,01 & 0,003 & 0,11 & 0,55 & 302,93 & $-0,76$ & $-7,5$ & 0,70747 & Mudstone \\
\hline & $43 C$ & 22,5 & 0,03 & & & & & $-0,74$ & $-7,4$ & & Mudstone \\
\hline & 43D & 32,5 & 0,11 & 0,068 & 1,57 & 10,21 & 2056,41 & $-0,26$ & $-8,4$ & & Mudstone \\
\hline \multirow{11}{*}{1} & $43 F$ & 66,5 & 0,05 & 0,022 & 0,15 & 2,72 & 668,30 & $-0,32$ & $-8,0$ & & Mudstone \\
\hline & 43G & 86,5 & $<0,01$ & 0,006 & 0,10 & 0,27 & 743,01 & $-0,08$ & $-7,5$ & 0,70779 & Mudstone \\
\hline & $43 \mathrm{H}$ & 98,5 & $<0,01$ & 0,007 & 0,06 & 0,58 & 541,41 & $-0,10$ & $-7,4$ & & Mudstone \\
\hline & $44 W$ & 150 & 0,004 & & & & & 0,03 & $-6,6$ & & Mudstone \\
\hline & $44 \mathrm{~T}$ & 162 & 0,09 & 0,016 & 0,07 & 3,42 & 262,12 & $-0,98$ & $-7,2$ & & Mudstone \\
\hline & $44 Q$ & 174 & 0,06 & 0,012 & 0,05 & 2,18 & 245,40 & $-0,38$ & $-6,9$ & & Mudstone \\
\hline & $44 N$ & 186 & 0,27 & & & & & $-0,40$ & $-7,2$ & & Mudstone \\
\hline & $44 K$ & 198 & 0,04 & 0,006 & 0,04 & 1,14 & 491,60 & $-0,51$ & $-7,2$ & 0,70768 & Mudstone \\
\hline & 44D & 214 & 0,27 & 0,028 & 0,13 & 5,29 & 224,58 & $-1,68$ & $-6,9$ & & Mudstone \\
\hline & $44 \mathrm{~F}$ & 222 & 0,01 & 0,001 & 0,02 & 0,05 & 300,56 & $-0,07$ & $-7,4$ & 0,70765 & Mudstone \\
\hline & $44 I$ & 234 & 0,14 & & & & & $-0,83$ & $-6,2$ & & Mudstone \\
\hline \multirow[t]{2}{*}{ S } & 45A & 242 & 0,08 & 0,058 & 0,18 & 11,15 & 615,50 & $-0,97$ & $-7,3$ & & Mudstone \\
\hline & $45 \mathrm{Z}$ & 258 & 0,01 & & & & & $-1,19$ & $-8,8$ & & Packestone \\
\hline \multirow[t]{15}{*}{2} & $45 \mathrm{~V}$ & 270 & 0,07 & 0,026 & 0,09 & 4,82 & 357,63 & $-1,09$ & $-7,9$ & & Mudstone \\
\hline & $45 \mathrm{~S}$ & 282 & 0,01 & 0,006 & 0,06 & 0,15 & 811,05 & $-1,39$ & $-8,1$ & 0,70770 & Mudstone \\
\hline & $45 P$ & 294 & 0,18 & 0,020 & 0,24 & 4,11 & 309,50 & $-1,70$ & $-7,4$ & & Mudstone \\
\hline & $45 M$ & 306 & 0,01 & 0,002 & 0,01 & 0,47 & 180,38 & $-1,19$ & $-7,7$ & 0,70771 & Mudstone \\
\hline & $45 \mathrm{~J}$ & 318 & 0,02 & 0,006 & 0,04 & 0,78 & 417,42 & $-1,10$ & $-8,5$ & & Mudstone \\
\hline & $45 G$ & 330 & 0,04 & 0,008 & 0,04 & 1,52 & 352,96 & $-1,19$ & $-8,8$ & 0,70769 & Mudstone \\
\hline & $45 \mathrm{E}$ & 338 & 0,04 & 0,007 & 0,04 & 0,74 & 555,83 & $-1,19$ & $-7,9$ & & Mudstone \\
\hline & 46 & 434 & 0,03 & 0,009 & 0,05 & 1,23 & 458,75 & $-1,34$ & $-6,9$ & 0,70763 & Mudstone \\
\hline & 50B & 474 & 0,09 & 0,004 & 0,02 & 0,89 & 270,01 & $-1,21$ & $-8,3$ & 0,70779 & Mudstone \\
\hline & 54 & 514 & 0,60 & 0,030 & 0,31 & 1,39 & 4460,68 & $-0,83$ & $-7,2$ & & Dolomudstone \\
\hline & 58 & 554 & 0,62 & 0,111 & 0,71 & 20,83 & 4849,49 & $-0,60$ & $-3,5$ & & Mudstone \\
\hline & 62 & 588 & 0,03 & 0,008 & 0,04 & 0,66 & 594,99 & $-0,63$ & $-7,5$ & 0,70773 & Mudstone \\
\hline & 64 & 678 & 0,01 & 0,009 & 0,04 & 0,24 & 446,83 & $-0,82$ & $-8,0$ & & Mudstone \\
\hline & 65 & 688 & 0,62 & 0,069 & 0,43 & 7,73 & 6075,49 & $-0,83$ & $-4,5$ & & Dolomudstone \\
\hline & 69 & 728 & 0,63 & 0,023 & 0,42 & 1,92 & 5995,61 & $-0,47$ & $-4,9$ & & Dolomito cristalino \\
\hline \multirow{2}{*}{$\mathbf{S}$} & 77 & 808 & 0,63 & 0,016 & 0,54 & 3,23 & 5078,42 & $-0,48$ & $-4,7$ & & Dolomito cristalino \\
\hline & 82 & 908 & 0,62 & 0,019 & 0,29 & 1,76 & 2793,17 & 0,15 & $-6,0$ & & Dolopackestone \\
\hline \multirow[t]{10}{*}{3} & 86 & 988 & 0,63 & 0,013 & 0,54 & 2,42 & 7549,13 & 0,15 & $-4,6$ & & Dolomito cristalino \\
\hline & 90 & 1068 & 0,62 & 0,022 & 0,30 & 1,35 & 4018,68 & 0,09 & $-4,6$ & & Dolograinstone \\
\hline & 94 & 1226 & 0,64 & 0,039 & 0,62 & 7,22 & 2442,92 & 3,97 & $-3,2$ & & Dolomito cristalino \\
\hline & 97 & 1286 & 0,63 & 0,456 & 1,20 & 21,61 & 2001,45 & 2,02 & $-3,4$ & & Dolowackestone \\
\hline & 98 & 1306 & 0,62 & 0,029 & 0,63 & 8,56 & 2958,53 & 0,43 & $-5,1$ & & Dolomudstone \\
\hline & 99 & 1326 & 0,62 & 0,023 & 0,41 & 2,75 & 2886,35 & 0,57 & $-4,8$ & & Dolomudstone \\
\hline & 100 & 1346 & 0,63 & 0,027 & 0,51 & 2,79 & 2904,64 & 2,15 & $-3,9$ & & Dolomudstone \\
\hline & 101 & 1366 & 0,63 & 0,014 & 0,36 & 2,40 & 2529,51 & 1,84 & $-3,8$ & 0,70849 & Dolograinstone \\
\hline & 19I & 1684 & 0,01 & 0,017 & 0,37 & 3,70 & 690,13 & $-4,99$ & $-7,0$ & & Mudstone \\
\hline & $19 H$ & 1686 & 0,01 & 0,012 & 0,12 & 2,37 & 318,52 & $-4,92$ & $-6,7$ & & Mudstone \\
\hline \multirow[t]{2}{*}{ S } & 19G & 1687 & 0,01 & 0,015 & 0,20 & 3,00 & 417,19 & $-7,47$ & $-7,6$ & 0,70882 & Mudstone \\
\hline & $19 F$ & 1689 & $<0,01$ & 0,017 & 0,37 & 3,16 & 1019,61 & $-6,50$ & $-7,7$ & & Mudstone \\
\hline \multirow[t]{3}{*}{8} & $19 E$ & 1691 & $<0,01$ & 0,010 & 0,09 & 1,45 & 464,99 & $-6,53$ & $-7,8$ & 0,70863 & Mudstone \\
\hline & 19D & 1692 & $<0,01$ & 0,006 & 0,22 & 1,50 & 513,62 & $-3,32$ & $-5,8$ & 0,70870 & Mudstone \\
\hline & 19C & 1696 & $<0,01$ & 0,005 & 0,06 & 0,57 & 531,30 & $-3,21$ & $-5,5$ & 0,70876 & Mudstone \\
\hline
\end{tabular}

Nota: seções estratigráficas (S1, S2, S3 e S8), amostras (Am.) e metros (m). 


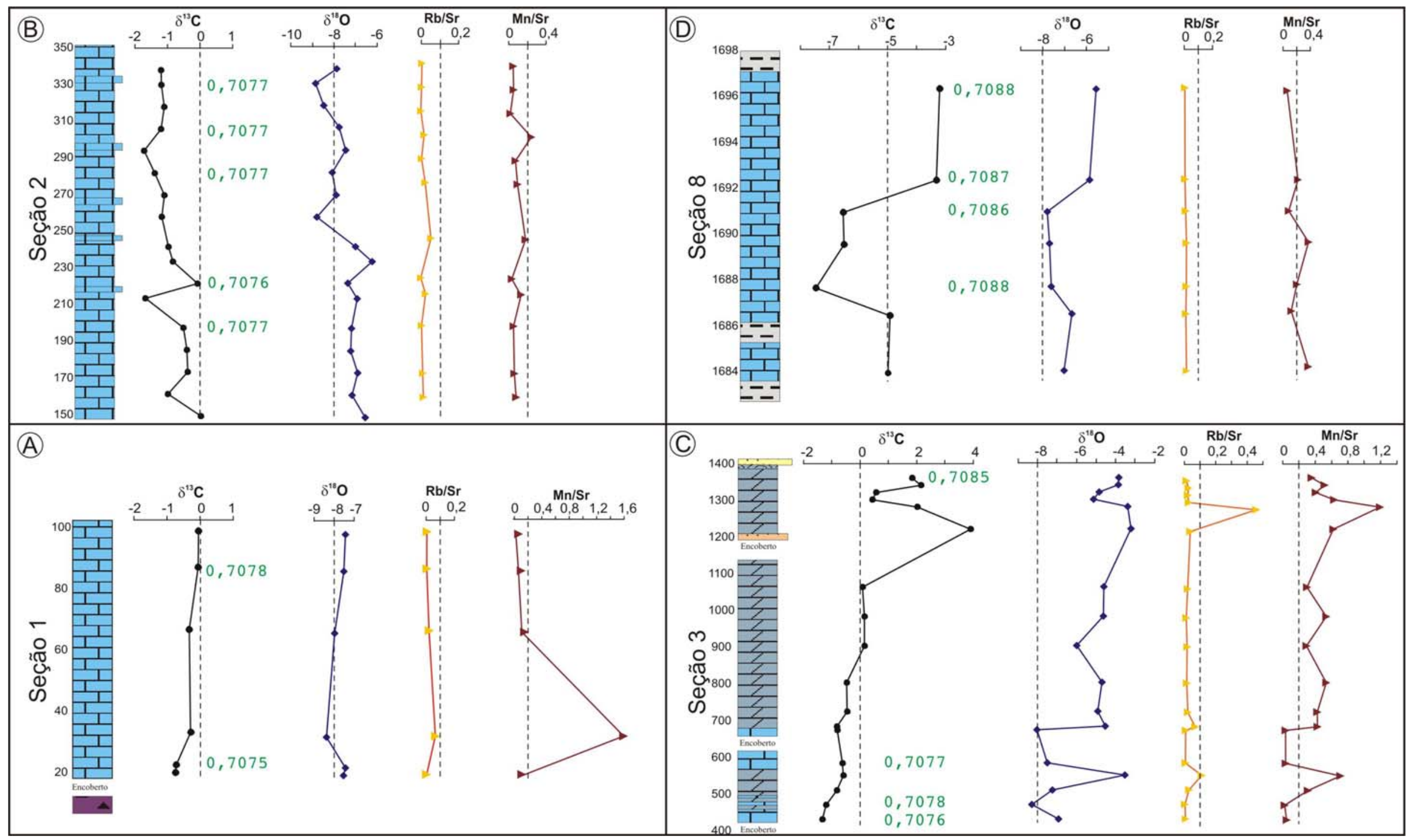

Figura 31. Quimioestratigrafia das seções 1 (A), 2 (B), 3 (C) e 8 (D), empilhadas estratigraficamente, de baixo para cima e da esquerda para a direita, para melhor visualização. As razões ${ }^{87} \mathrm{Sr} /{ }^{86} \mathrm{Sr}$ estão notadas em verde, nas respectivas posições estratigráficas. 

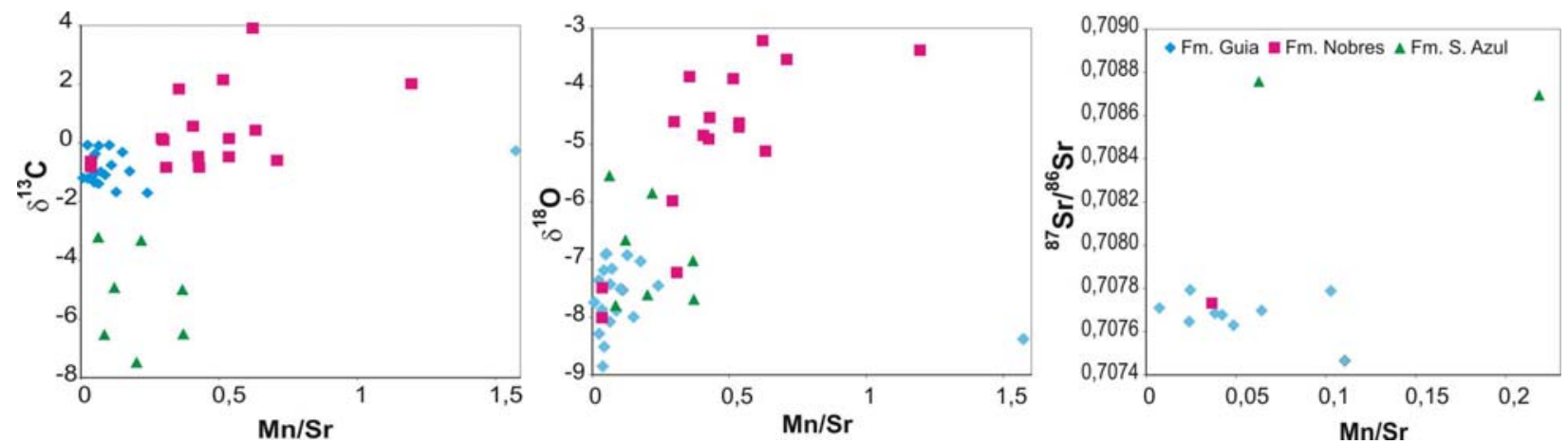

Figura 32. Gráficos de dispersão entre a razão $\mathrm{Mn} / \mathrm{Sr}$ e os valores de $\delta^{13} \mathrm{C}, \delta^{18} \mathrm{O}$ e ${ }^{87} \mathrm{Sr} /{ }^{86} \mathrm{Sr}$. Todas as amostras possuem razões $\mathrm{Mn} / \mathrm{Sr}$ inferiores a 2, sendo inferiores a 0,25 para as amostras analisadas para ${ }^{87} \mathrm{Sr} /{ }^{86} \mathrm{Sr}$, o que garante empiricamente a qualidade dos resultados isotópicos. As amostras correspondentes da Formação Nobres são as que possuem as razões $\mathrm{Mn} / \mathrm{Sr}$ mais altas e se mostram isotopicamente mais pesadas. A correlação entre os valores não segue um padrão bem definido nos gráficos $\delta^{13} \mathrm{C}$ vs. $\mathrm{Mn} / \mathrm{Sr}, \mathrm{e}^{87} \mathrm{Sr}{ }^{86} \mathrm{Sr}$ vs. $\mathrm{Mn} / \mathrm{Sr}$, mas tende a uma correlação aproximadamente positiva quando comparados $\delta^{18} \mathrm{O}$ vs. $\mathrm{Mn} / \mathrm{Sr}$.
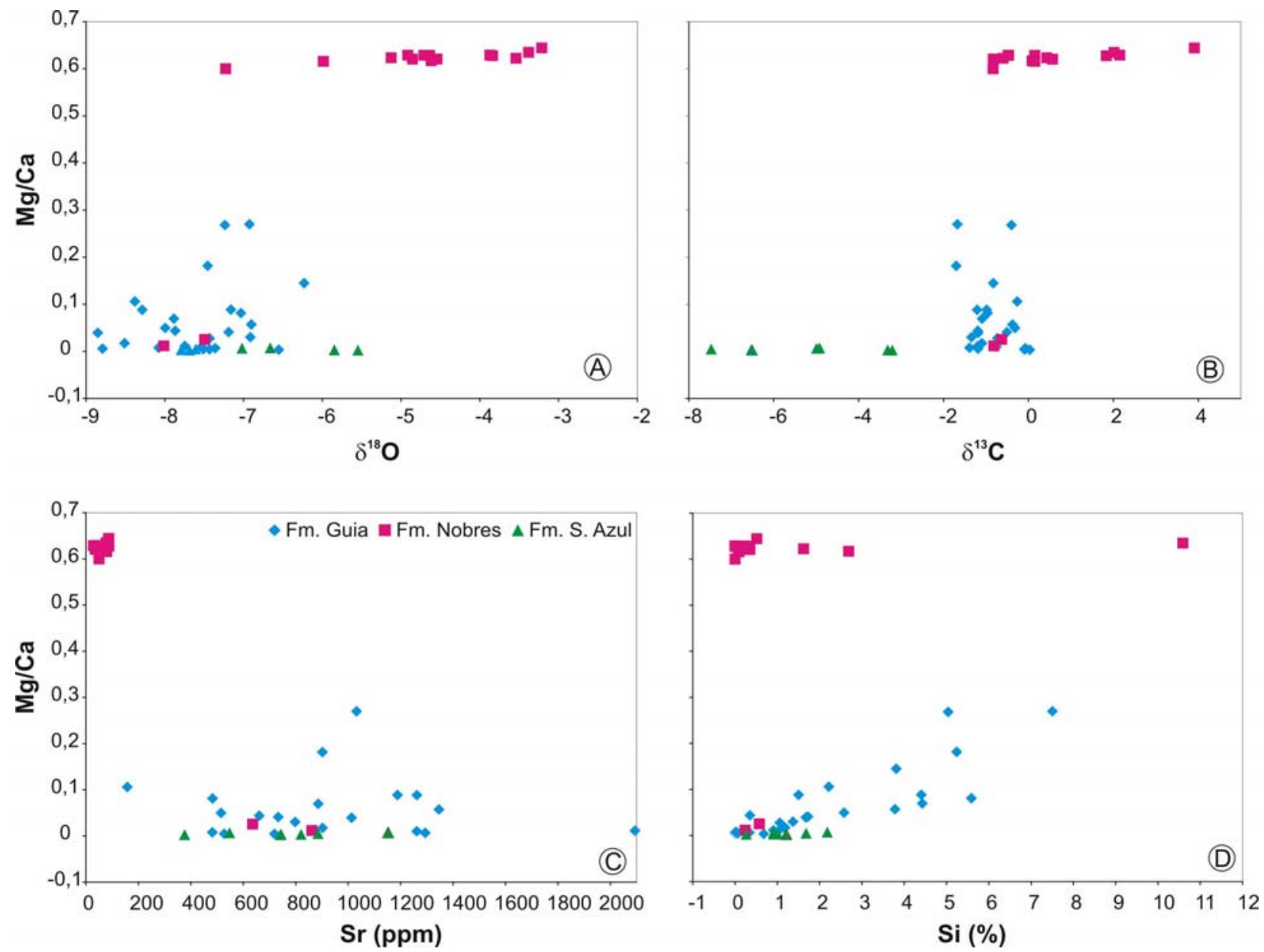

Figura 33. Gráficos de dispersão da razão $\mathrm{Mg} / \mathrm{Ca}$ versus $\delta^{18} \mathrm{O}(\mathrm{A}), \delta^{13} \mathrm{C}(\mathrm{B}), \mathrm{Sr}(\mathrm{C})$ e $\mathrm{Si}(\mathrm{D})$. Nas figuras $\mathrm{A}$ e $\mathrm{B}$ não se observa correlação positiva entre $\mathrm{Mg} / \mathrm{Ca}$ e $\delta^{18} \mathrm{O}$ ou $\delta^{13} \mathrm{C}$, embora seja evidente que os dolomitos da Formação Nobres sejam isotopicamente mais pesados que os calcários das formações Guia e Serra Azul. Os termos dolomíticos também são os que apresentam a menor teor de $\mathrm{Sr}(\mathrm{C})$. Em relação ao Si (D) não há boa correlação global, no entanto as amostras da Formação Guia apresentam uma tendência de correlação positiva. 


\subsubsection{Seção 8}

Nesta seção de topo foram analisadas 7 amostras de calcário da Formação Serra Azul (Tabela 6, Figura 31D). Os valores de $\delta^{13} \mathrm{C}$ obtidos variam entre $-3,21 \mathrm{e}-7,47$, confirmando a existência do evento glacial. Os resultados de $\delta^{18} \mathrm{O}$ variam entre $-5,55 \mathrm{e}-7,79$, sem correlação aparente com razões $\mathrm{Mg} / \mathrm{Ca}$ (Figura 33A). Para os valores de ${ }^{87} \mathrm{Sr} /{ }^{86} \mathrm{Sr}$, analisaram-se duas amostras, que forneceram razões de 0,70869 e 0,70876. As razões $\mathrm{Mn} / \mathrm{Sr}$ de 0,08 a 0,28 (Figura 31) e Fe/Sr de 0,40 a 1,07 asseguram a preservação das razões isotópicas originais, com exceção de uma amostra $(\mathrm{Mn} / \mathrm{Sr}$ 0,478 e $\mathrm{Fe} / \mathrm{Sr}$ 2,259). As razões $\mathrm{Rb} / \mathrm{Sr}$ são 0,006 e 0,005, respectivamente, evidenciando uma quantidade insignificante de terrígenos que pudessem conter $\mathrm{Rb}$.

\subsection{PROVENIÊNCIA DE SEDIMENTOS}

Foram realizadas análises isotópicas de $\mathrm{Sm}-\mathrm{Nd}$ em 9 amostras de sedimentos da Formação Serra Azul (Tabela 7), coletadas em três locais distintos, sendo dois no flanco sul da Sinclinal Serra Azul e um na reserva ambiental da Cimenteira Itaú próximo à cidade de Nobres.

Tabela 7. Resultados da análise Sm/Nd obtidos para os pelitos da Formação Serra Azul.

\begin{tabular}{|c|c|c|c|c|c|c|c|c|c|c|c|}
\hline & Am. & Rocha & $\begin{array}{c}\text { Sm } \\
(\mathrm{ppm})\end{array}$ & $\begin{array}{c}\text { Nd } \\
(\mathrm{ppm})\end{array}$ & $\begin{array}{l}{ }^{147} \mathrm{Sm} / \\
{ }^{144} \mathrm{Nd}\end{array}$ & Erro & $\begin{array}{l}{ }^{143} \mathrm{Nd} / \\
{ }^{144} \mathrm{Nd}\end{array}$ & Erro & $\mathbf{f}_{\mathrm{Sm} / \mathrm{Nd}}$ & $\begin{array}{l}T_{D M} \\
\text { (Ga) }\end{array}$ & $\varepsilon_{(0)}$ \\
\hline & 06A & Diamictito & 7,344 & 38,967 & 0,1140 & 0,0004 & 0,511965 & 0,000013 & $-0,42$ & 1,6 & $-13,12$ \\
\hline S & $06 B$ & $\begin{array}{l}\text { Laminito } \\
\text { vermelho }\end{array}$ & 16,047 & 82,741 & 0,1173 & 0,0004 & 0,511848 & 0,000010 & $-0,40$ & 1,9 & $-15,42$ \\
\hline \multirow[t]{2}{*}{4} & $06 C$ & $\begin{array}{c}\text { Laminito } \\
\text { amarelo }\end{array}$ & 18,211 & 90,551 & 0,1216 & 0,0004 & 0,511909 & 0,000010 & $-0,38$ & 1,9 & $-14,23$ \\
\hline & 07 & $\begin{array}{c}\text { Laminito } \\
\text { cinza }\end{array}$ & 12,535 & 63,803 & 0,1188 & 0,0004 & 0,511906 & 0,000011 & $-0,40$ & 1,8 & $-14,29$ \\
\hline S & 19B & $\begin{array}{l}\text { Laminito } \\
\text { cinza }\end{array}$ & 12,689 & 60,564 & 0,1267 & 0,0004 & 0,511923 & 0,000010 & $-0,36$ & 2,0 & $-13,96$ \\
\hline 8 & $19 \mathrm{~J}$ & $\begin{array}{l}\text { Laminito } \\
\text { vermelho }\end{array}$ & 14,043 & 74,987 & 0,1132 & 0,0004 & 0,511979 & 0,000008 & $-0,42$ & 1,6 & $-12,86$ \\
\hline \multirow[b]{2}{*}{ S } & $20 B$ & Diamictito & 6,988 & 36,194 & 0,1168 & 0,0004 & 0,511946 & 0,000011 & $-0,41$ & 1,7 & $-13,49$ \\
\hline & $20 \mathrm{C}$ & $\begin{array}{l}\text { Laminito } \\
\text { vermelho }\end{array}$ & 9,448 & 51,134 & 0,1117 & 0,0004 & 0,511870 & 0,000008 & $-0,43$ & 1,8 & $-14,97$ \\
\hline 5 & 20D & $\begin{array}{l}\text { Laminito } \\
\text { amarelo }\end{array}$ & 19,756 & 102,065 & 0,1170 & 0,0004 & 0,511874 & 0,000011 & $-0,40$ & 1,8 & $-14,90$ \\
\hline
\end{tabular}

Nota: Idades modelo $\mathrm{T}_{\mathrm{DM}}$ calculados de acordo com DePaolo (1981); Seções (S)

Na seção tipo da formação (seção 4), situada na região da Serra Azul, (Figura 17) foram analisadas quatro amostras, constando da matriz do diamictito, laminito vermelho, laminito 
amarelo e laminito cinza. As idades modelo Sm-Nd são de 1,6 Ga para o diamictito, 1,9 Ga, para os laminitos amarelo e vermelho e 1,8 Ga para o laminito cinza (Figura 34).Os valores obtidos de $\varepsilon_{\mathrm{Nd}}$ foram todos negativos: - 13,12 para o diamictito, - 15,42 para a estreita camada de laminito amarelo sobreposta, $-14,23$ para o início da espessa seqüência de laminito vermelho e $-14,29$ para o laminito cinza de topo.

Em outra seção da Sinclinal Serra Azul (seção 5), mais a oeste da anterior, analisaram-se três amostras, sendo diamictito, laminito amarelo e laminito vermelho, todas próximas entre si. As idades modelo Sm-Nd foram 1,7 Ga para o diamictito e 1,8 Ga para laminitos amarelo e vermelho (Figura 34 ). Os valores $\varepsilon_{\mathrm{Nd}}$ obtidos foram - 13,49 para o diamictito, $-14,97$ para o laminito amarelo e $-14,52$ para o laminito vermelho.

Duas amostras dos laminitos vermelho e cinza, da reserva ambiental da Cimenteira Itaú (seção 8), foram analisadas. As idades modelo Sm-Nd são de 1,6 Ga para o laminito vermelho e de 2,0 Ga para o laminito cinza de topo (Figura 34). Apresentaram valores igualmente negativos de $\varepsilon_{\mathrm{Nd}}$, sendo - 12,86 para o laminito vermelho e - 13,96 para o laminito cinza logo acima dos calcários de capa da Formação Serra Azul.

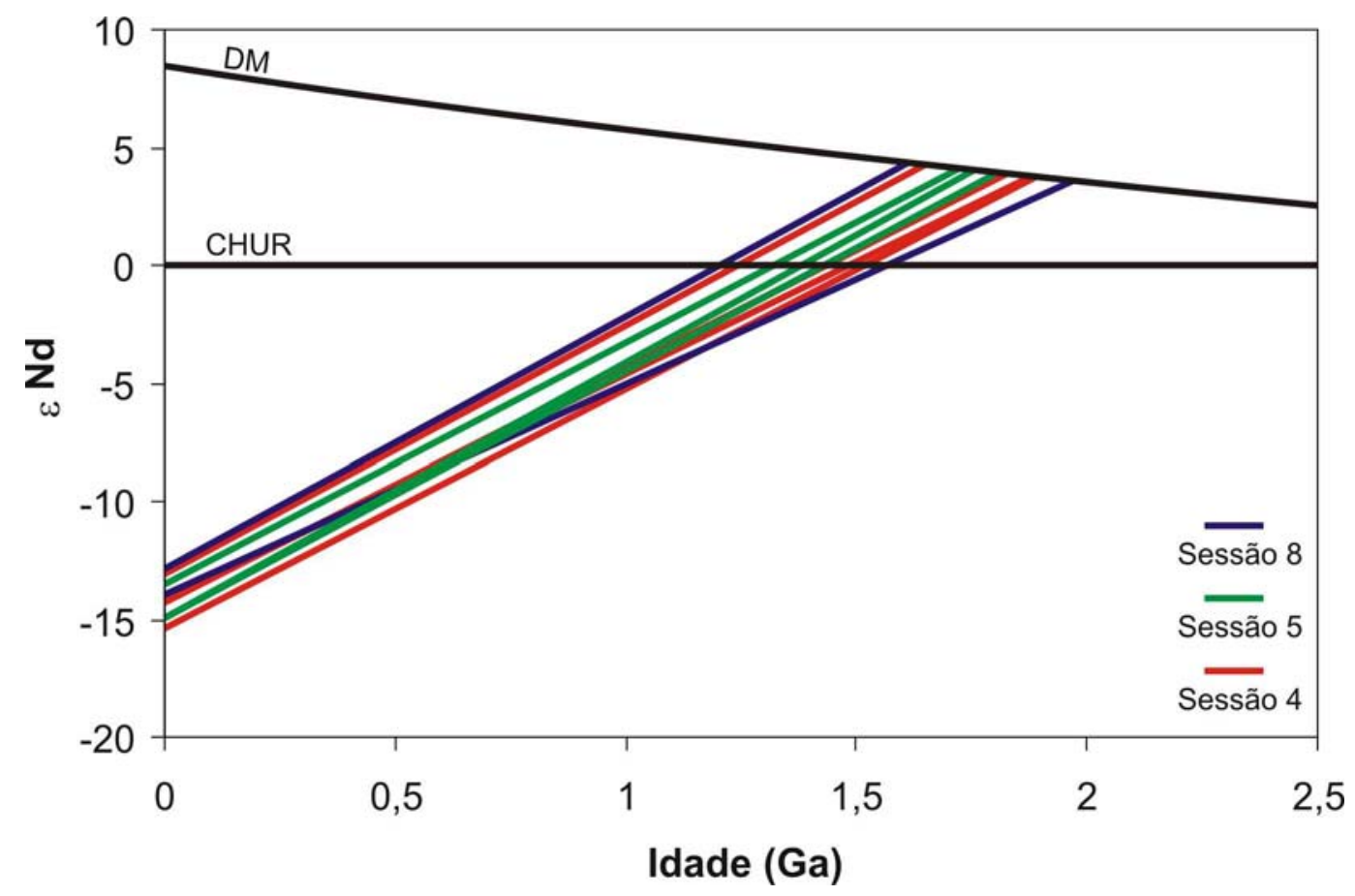

Figura 34. Gráfico apresentando as idades $\mathrm{T}_{\mathrm{DM}}$ em relação ao $\varepsilon_{\mathrm{Nd}}$ das amostras analisadas. As 4 linhas em vermelho são dados da seção 4, as 2 linhas em verde são dados da seção 5 e as 2 linhas em azul são dados da seção 8. 


\section{CAPÍTULO 6 DISCUSSÃO}

Neste capítulo serão discutidos os resultados obtidos à luz dos conhecimentos geológicos atuais, principalmente no que diz respeito à quimioestratigrafia isotópica de $\mathrm{C}, \mathrm{O}$ e $\mathrm{Sr}$, visando correlacionar a sucessão sedimentar estudada com outras ocorrências ediacarianas no mundo.

\subsection{EVOLUÇÃO PALEOAMBIENTAL}

Por questão de simples terminologia, será utilizado o termo "Bacia Paraguai", ao invés de Faixa Paraguai, visando evitar confusão entre análise estratigráfica-sedimentológica e tectônica.

Embora as condições de campo não tenham permitido um minucioso detalhamento que possibilitasse a identificação dos vários pequenos ciclos existentes, as 8 seções estratigráficas estudadas permitem o reconhecimento dos grandes ciclos deposicionais da Bacia Paraguai em Mato Grosso, que refletem a evolução global desta bacia na região estudada,

As seções 1, 2 e 3 formam uma única sucessão de rochas predominantemente carbonáticas (ver Figura 18, Capítulo 5), podendo, assim, serem empilhadas. Esta sucessão é constituída de carbonatos do Grupo Araras, sendo as seções 1 e 2 representantes da Formação Guia e a seção 3 da Formação Nobres. As seções 4, 5, 6, 7 e 8 fazem parte de uma mesma unidade litoestratigráfica (ver Figura 18, Capítulo 5) e podem ser correlacionadas entre si, de forma a melhor compreender a seqüência completa. Esta unidade litoestratigráfica é denominada neste trabalho Formação Serra Azul (Figueiredo et al., 2005a e Alvarenga et al., submetido), composta de diamictitos, laminitos e calcários. Esta formação encontra-se estratigraficamente sobreposta ao Grupo Araras.

Numa primeira análise, é possível identificar dois importantes eventos glaciais na Bacia Paraguai, sendo o mais antigo representado pela Formação Puga e o mais novo pelos diamictitos da Formação Serra Azul, conforme as evidências apresentadas no Capítulo 5 (composição polimítica com clastos estriados, facetados e polidos). O primeiro evento glacial é seguido pela deposição de uma espessa sucessão de rochas dominantemente carbonáticas, cerca de $1400 \mathrm{~m}$, representada pelo Grupo Araras. O segundo evento glacial é sobreposto pela deposição de uma 
espessa sucessão de laminitos, cerca de 300 m, com ocorrência de calcário e arenito no topo, representada pela da Formação Serra Azul.

Esta sucessão indica a presença de, pelo menos, dois ciclos progradante-retrogradantes completos na Bacia Paraguai (Figura 35). Observa-se o início da primeira seqüência retrogradacional a partir dos diamictitos glaciais da Formação Puga em direção ao topo da Formação Guia. Assim, sobrepostos aos diamictitos de ambiente raso, depositaram-se cerca de $500 \mathrm{~m}$ de calcários com laminação truncada e ondulada, de ambiente moderadamente raso a profundo, seguidos por calcários rítmicos ricos em matéria orgânica, de ambiente profundo e anóxico, marcando uma inundação máxima. Esta seqüência evidencia uma transgressão marinha, provavelmente relacionada à deglaciação e conseqüente inundação da plataforma (Figuras 36A e 36B).

Uma seqüência progradacional inicia-se a partir do topo da Formação Guia em direção ao topo da Formação Nobres. Sobreposta aos calcários ricos em matéria orgânica da Formação Guia, ocorre a Formação Nobres, com cerca de $900 \mathrm{~m}$ de espessura. Inicia-se com dolomitos secundários intercalados aos calcários, ainda guardando as estruturas originais, passando a dolomitos completamente recristalizados, mostrando a presença de fluídos diagenéticos dolomitizantes, talvez decorrentes da interação com águas não-marinhas. Em direção ao topo ocorrem camadas oncolíticas, peloidais, intraclásticas e arcoseanas, evidenciando ambiente de mais alta energia. Estas texturas são cada vez mais freqüentes em direção ao topo, ocorrendo também oólitos e seqüências turbidíticas, mostrando progressivo arrasamento da bacia, com presença de correntes de turbidez. No topo, ocorrem dolomitos bioconstruídos, com porosidade fenestral, intercalados a dolomudstones primários, possivelmente devido às exposições subaéreas episódicas, com retenção de água em corpos d'água temporariamente restritos, evidenciando ambiente de supramaré. Estas bioconstruções são sobrepostas por estromatólitos, que marcam um ambiente de intermaré superior. O contato de topo da Formação Nobres, nesta sucessão, é brusco com a Formação Raizama, não se observando sua relação com a Formação Serra Azul. É possível que a presença de carbonato bioconstruído no topo seja uma evidência da formação de um alto topográfico, tipo recife, que não possibilitou a deposição dos sedimentos glaciais da Formação Serra Azul (Figuras 36C e 36D).

Uma nova seqüência retrogradacional se inicia a partir da deposição dos diamictitos da Formação Serra Azul em direção aos laminitos de topo da mesma formação. Neste contexto, depositaram-se mais de $70 \mathrm{~m}$ de diamictitos de origem glacial, com clastos aparentemente granodecrescentes em direção ao topo. $\mathrm{Na}$ base esta seqüência, ocorrem mega-oóides 


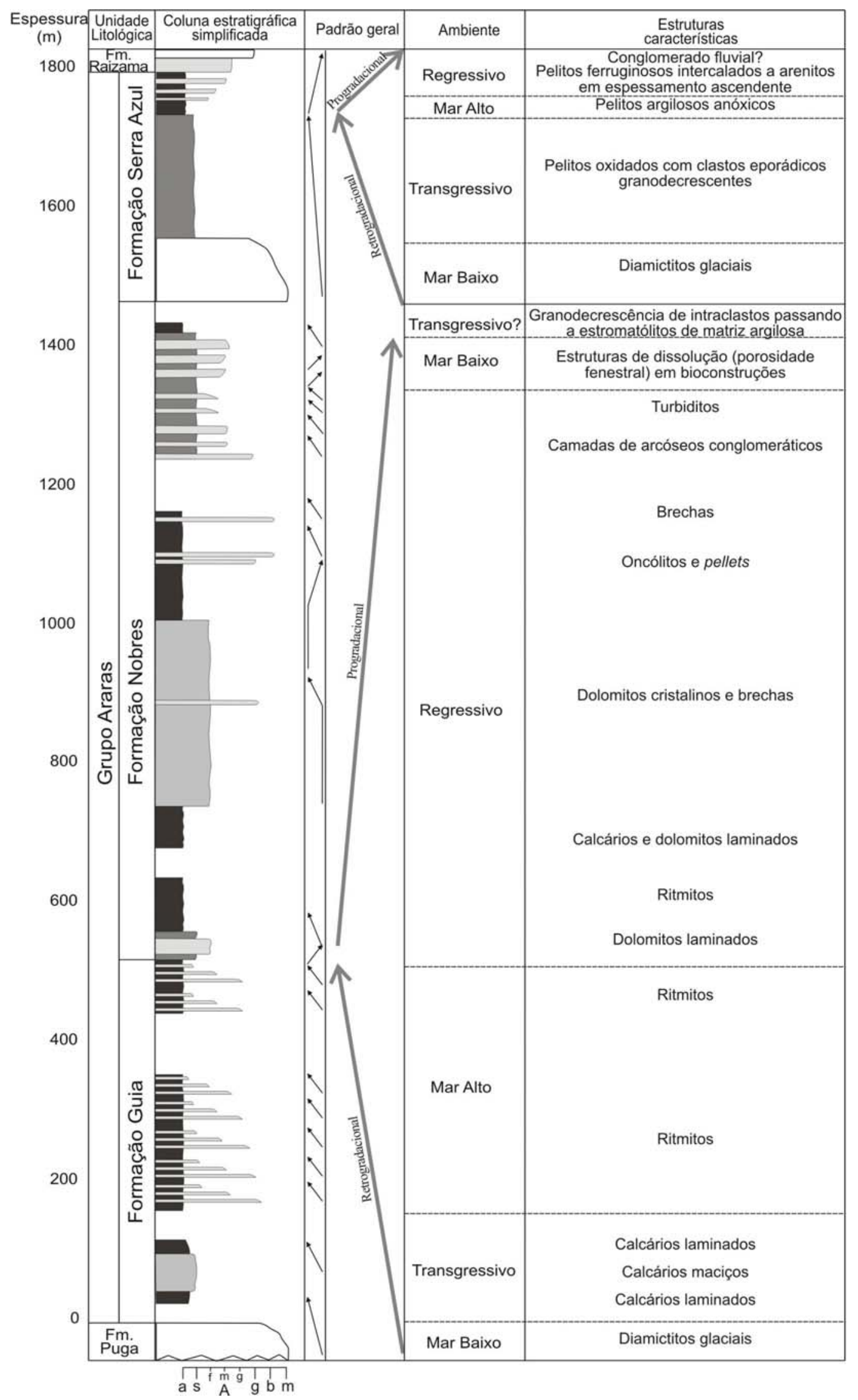

Figura 35. Coluna estratigráfica regional simplificada das áreas estudadas. A granulometria máxima está notada como: (a) argila, (s) silte, (Af) areia fina, (Am) areia média, (Ag) areia grossa, (g) grânulo, (b) bloco, $(\mathrm{m})$ matacão. 
associados a brechas, completamente substituídos por óxido de ferro, e ocorrência de Fe e Mn associados à grande quantidade de chert branco e pelitos com lâminas ricas em hematita (Ganzer \& Figueiredo, 2004). De acordo com a literatura, a origem de mega-oóides no Neoproterozóico ainda é uma incógnita, embora Sumner \& Grotzinger (1993) sugiram que sejam o resultado das flutuações climáticas associadas ao crescimento e redução de extensas camadas de gelo. Muitas camadas de oóides gigantes têm sido observadas em outras bacias estratigraficamente abaixo de tilitos (Tucker, 1983 \& Swett \& Knoll, 1989) ou dentro de depósitos glaciais (Singh, 1987).

Subindo na seqüência retrogradacional, acima dos diamictitos, depositou-se uma persistente camada $(\sim 60 \mathrm{~cm})$ de laminito silto-argiloso amarelo, que provavelmente marca mudanças no ambiente deposicional, de origem ainda não muito clara. Acima deste, seguem-se os $170 \mathrm{~m}$ de laminito silto-argiloso vermelho, contendo clastos esporádicos, evidenciando um ambiente oxidante durante a inundação da plataforma devido ao degelo. Sobre este laminito vermelho, depositou-se cerca de $20 \mathrm{~m}$ de laminito argilo-síltico cinza, em contato gradacional, provavelmente marcando um ambiente subanóxico da inundação máxima desta seqüência (Figura 36E). Próximo à base deste laminito cinza ocorre uma camada calcária de $12 \mathrm{~m}$, onde se observam estruturas que corroboram com a idéia de ambiente profundo, como deformações geradas por escorregamento, laminação típica de ambiente de baixa energia e textura nodular, também gerada pela deformação progressiva de lâminas intercaladas à lama em ambiente profundo (Möller \& Kvingan, 1988).

A partir desta porção mais basal do laminito cinza, inicia-se nova seqüência progradacional (cerca de $60 \mathrm{~m}$ ) em direção à base da Formação Raizama. Assim, os laminitos cinza passam a apresentar intensa impregnação por óxido de ferro e ocorrência de intercalações de camadas de arenito fino, cada vez mais freqüentes em direção ao topo da Formação Serra Azul. Esta sucessão sugere um rebaixamento relativo do nível do mar que possibilitou a entrada de areia na bacia, possivelmente marcando evolução de um pró-delta para um talude do delta. Os arenitos mostram uma granocrescência em camadas cada vez mais espessas para o topo, terminando com a deposição de conglomerado suportado por grânulos de quartzo e cimentado por óxido de ferro, evidência da evolução de um ambiente de talude para a crista de delta, talvez chegando a fluvial distal (Figura 36F).

No Neoproterozóico, embora os estromatólitos tenham potencial de construir recifes semelhantes aos atuais (Grotzinger, 1988), predominavam as plataformas tipo rampa em relação as que possuem talude (Grotzinger \& James 2000). De acordo com a sucessão de rochas carbonáticas apresentada, optou-se por uma geometria de plataforma inicialmente tipo rampa, na 

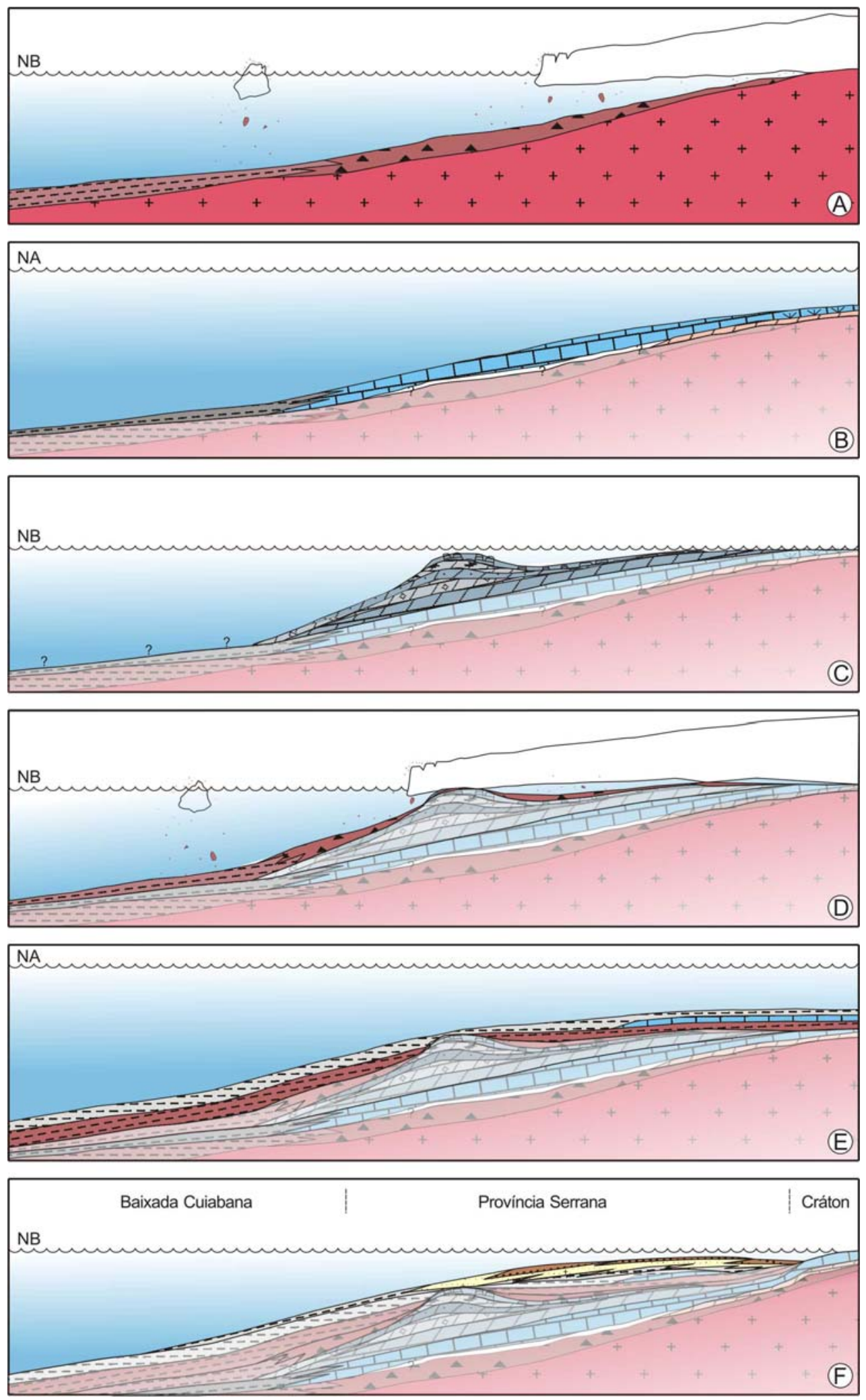

Figura 36. Evolução sedimentar da Bacia Paraguai em Mato Grosso: (A) Glaciação Puga, com deposição da Formação Puga e maior parte do Grupo Cuiabá; (B) deglaciação Puga, com deposição de carbonatos predominantemente calcários da Formação Guia; (C) regressão marinha e aquecimento, com deposição da Formação Nobres; (D) glaciação Serra Azul, com deposição dos diamictitos da formação homônima; (E) deglaciação Serra Azul, com deposição dos laminitos e calcários da formação homônima; (F) regressão marinha com a deposição de camadas de arenito intercaladas com pelitos da Formação Serra Azul progredindo para os arenitos e conglomerados da Formação Raizama. 
qual se depositaram os carbonatos do Grupo Araras (Figura 36B). Provavelmente ocorreu uma transição morfológica de rampa para uma plataforma com talude, como sugerido pelo aparecimento de carbonatos oncolíticos e estromatólitos, evidências da bioconstrução de recifes, a medida que a bacia ficava mais rasa (Figura 36C). Este modelo é similar aos adotados para outras bacias carbonáticas neoproterozóicas, como a Bacia Gourma no oeste africano (BertrandSarfati \& Moussine-Pouchkine, 1983) e a Bacia Omã Central no sul do país homônimo (Mattes \& Conway Morris, 1990).

O ambiente reinante sobre esta plataforma passaria a ser influenciado por uma glaciação, possivelmente marcado pela instalação de uma plataforma de gelo marinha, possivelmente ancorada nos recifes existentes, conforme modelo de deposição a partir de plataforma de gelo marinho (Eyles \& Menzies, 1983). Seguindo este modelo, ter-se-ia a deposição de tilitos subaquosos nos vales, com retrabalhamento de diamictitos glaciais em mar aberto (Figura 36D). $\mathrm{O}$ degelo provocaria a inundação da plataforma e deposição dos laminitos (Figura 36E). A inexistência de sedimentos glaciais sobre o Grupo Araras na Serra "Vai quem qué" pode estar relacionado ao alto topográfico existente (Figura 36D), devido aos recifes, ou a uma intensa erosão causada posteriormente pelo rebaixamento do nível do mar, ou ainda a interação de ambos (Figura 36F).

\subsection{DIAGÊNESE E PROCESSOS PÓS-DEPOSICIONAIS}

O intervalo estratigráfico (de até $40 \mathrm{~m}$ ) entre as amostras analisadas não permite o detalhamento de ciclos deposicionais individuais, no entanto, o intervalo utilizado possibilita uma avaliação global do comportamento químico dos diversos ambientes deposicionais, sob a influência de grandes ciclos de arrasamento/inundação e diagênese, ao longo da sucessão analisada.

Desta forma, a análise química torna possível uma avaliação do estado de alteração das rochas carbonáticas, principalmente em relação às razões isotópicas obtidas. Ou seja, constitui um padrão empírico que permite identificar possíveis alterações posteriores à deposição carbonática, como percolação de água doce (meteórica e freática) ou intersticial, interação com salmouras e outros fluídos não-marinhos, que possam ter alterado as razões isotópicas originais, adquiridas da água do mar no instante da deposição. Os valores de $\delta^{18} \mathrm{O}$ são comumente mais utilizados como indicadores de alteração pós-deposicional, não se atribuindo muita confiabilidade a estes valores como sendo primários (Kaufman \& Knoll, 1995). 
Assim, para confirmar este pressuposto nos carbonatos estudados, numa primeira análise global, compararam-se os valores isotópicos para C e O (Figura 37, Tabela 6), distinguindo-se as formações Guia, Nobres e Serra Azul. Observa-se não haver correlação entre os valores de $\delta^{13} \mathrm{C}$ e $\delta^{18} \mathrm{O}$ nas formações Guia e Nobres, enquanto que na Formação Serra Azul nota-se certa correlação entre os valores isotópicos. De acordo com a literatura, esta correlação positiva sugere uma possível alteração dos valores primários, que será melhor conferida, mais adiante, por meio de outros parâmetros, embora as razões $\mathrm{Mn} / \mathrm{Sr}$ apresentadas no Capítulo 5 estejam todas abaixo de 0,4 , quando o limite estabelecido, que garante uma boa qualidade das amostras para este tipo de análise, é de 2 (Veizer, 1983).

Observou-se também, para os carbonatos analisados, a existência de uma correlação entre os valores de $\delta^{18} \mathrm{O}$ e os ambientes de deposição (Figura 37), mesmo em se tratando de carbonatos precambrianos, que dificilmente guardam a composição isotópica de $\mathrm{O}$ original da água do mar (Kah, 2000). Na sucessão estudada, os carbonatos de inframaré, depositados provavelmente durante período de degelo (formações Guia e Serra Azul), possuem valores mais negativos ( 9 a ca. - $6 \%$ ), enquanto que os carbonatos de intermaré (ca. - 6 a ca. $-3,3 \%$ ) a supramaré $(<-$ 4\%o), depositados durante período de estabilização climática, talvez interglacial (Formação Nobres), possuem os valores mais altos (Tabela 6). Também, os mesmos carbonatos depositados durante a deglaciação possuem valores de $\delta^{13} \mathrm{C}$ negativos, mostrando uma menor atividade biológica, enquanto que aqueles depositados durante estabilização climática possuem valores de $\delta^{13} \mathrm{C}$ levemente negativos a fortemente positivos, evidência de grande atividade biológica.

Os dados de $\delta^{18} \mathrm{O}$ sugerem, adicionalmente, a interação da água do mar com fluídos mais leves (enriquecidos em ${ }^{16} \mathrm{O}$ ) durante a deposição das formações Guia e Serra Azul (Figura 37), possivelmente provenientes das águas de degelo, como proposto por Corfield (1994). Adotandose o modelo da Snowball Earth (Hoffman \& Schrag, 2000), durante este período é possível que a umidade do ar tenha aumentado significantemente, propiciando também o aumento da pluviometria, que somada às águas de degelo, em escala mundial, aumentaria a quantidade de água doce misturada às águas marinhas. 


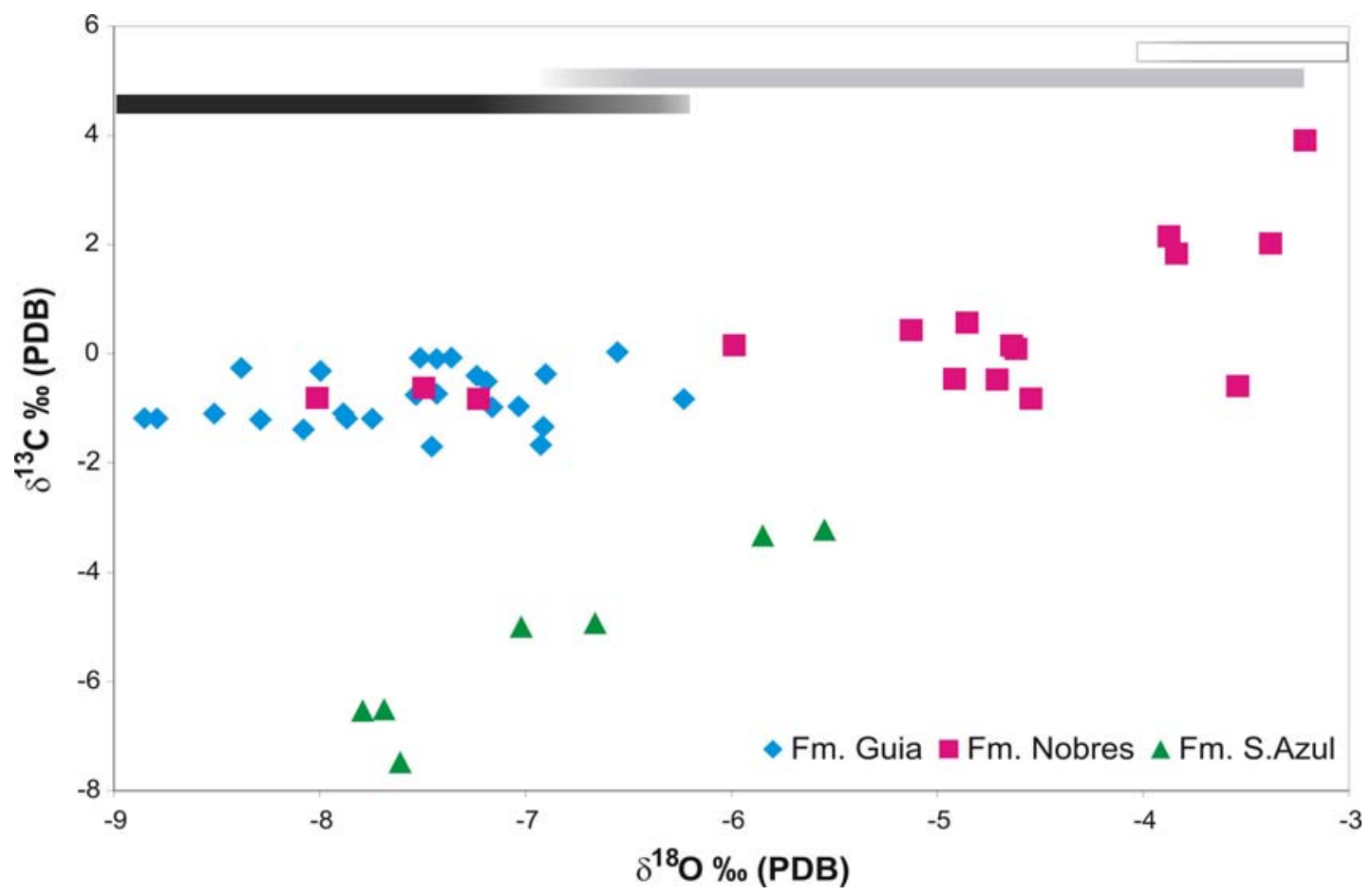

Figura 37. Dados isotópicos de $\mathrm{C}$ e $\mathrm{O}$ obtidos em carbonatos. A linha preta corresponde a ambiente de inframaré, a linha cinza de intermaré e a linha branca de supramaré.

A razão $\mathrm{Sr} / \mathrm{Ca}$ e concentração de $\mathrm{Mn}$ nos carbonatos fornecem uma indicação sensível de alteração diagenética, pois, durante a troca com fluídos diagenéticos, o Mn é comumente incorporado em sedimentos carbonáticos, enquanto que o $\mathrm{Sr}$ é lixiviado da estrutura do carbonato (Brand \& Veizer, 1980). Ou seja, a interação de um carbonato marinho com água doce, meteórica ou salmouras evaporíticas, resultará em uma rápida diminuição da razão $\mathrm{Sr} / \mathrm{Ca}$ seguida do aumento na abundância de Mn (Figura 38, Tabela 5).

De maneira geral, os carbonatos estudados apresentam baixa razão $\mathrm{Sr} / \mathrm{Ca}$, em especial os termos mais dolomíticos da Formação Nobres. As razões Sr/Ca para os calcários pós-glaciais das formações Guia e Serra Azul, incluindo duas amostras da Formação Nobres, estão na maioria, entre 0,006 e 0,001, enquanto que para os dolomitos da Formação Nobres estão bem abaixo de 0,001 (Figura 38, Tabela 5). As baixas razões dos dolomitos da Formação Nobres indicam que a dolomitização ocorreu na presença de fluídos empobrecidos em $\mathrm{Sr}$, como água doce ou meteórica, talvez freática devido ao arrasamento da bacia.

$\mathrm{Na}$ literatura, os altos teores de Mn nos carbonatos, se considerados secundários, indicam a interação da rocha com fluídos diagenéticos ricos em Mn (Jacobsen \& Kaufman, 1999), enquanto que, se considerados primários, podem indicar a composição original do oceano neoproterozóico pós-glacial no momento da deposição carbonática (Halverson et al., 2004). As 
abundâncias de Mn variam bastante nos carbonatos estudados, com valores abaixo de 0,025\%, sendo que para os calcários pós-glaciais (formações Guia e Serra Azul) observa-se mais alto teor de Mn (Tabela 5). Pelo fato destes calcários pós-glaciais apresentarem também altas razões de $\mathrm{Sr} / \mathrm{Ca}$, que assegura a ausência de percolação de fluídos não-marinhos tardios, seus teores mais altos de Mn indicam uma interação da água do mar com fluídos ricos em Mn no momento da deposição, talvez água proveniente do degelo mais água meteórica. Teores bem mais altos de Mn $(0,07$ a $0,2 \%)$ foram medidos nos dolomitos de capa da glaciação Puga, na região cratônica, por Font (2005), que asseguram a deposição primária destes dolomitos mediada por bactérias sulfato-redutoras.

Para os dolomitos, os valores de Mn estão abaixo de 0,01\% (Tabela 5), demonstrando uma interação pós-deposicional não tão intensa com fluídos ricos em $\mathrm{Mn}$. Os valores mais altos de Mn estão associados aos dolomitos impuros e turbidíticos, coincidentemente com altos valores de $\mathrm{Fe}$, Si e $\mathrm{Rb}$ (ver Tabela 5, Capítulo 5), indicando a presença de minerais terrígenos ricos nestes elementos. Nos demais dolomitos da Formação Nobres, observa-se um pequeno aumento dos teores de $\mathrm{Mn}$ em direção ao topo, onde se encontram evidências de dissolução (porosidade fenestral), possivelmente devido à interação da rocha com água doce e/ou meteórica, devido à exposição local de dolomitos bioconstruídos, conforme a bacia ficava mais rasa, ou talvez com salmouras originadas a partir de corpos de água presos em recifes bioconstruídos, precipitando finas camadas de dolomudstone primário.

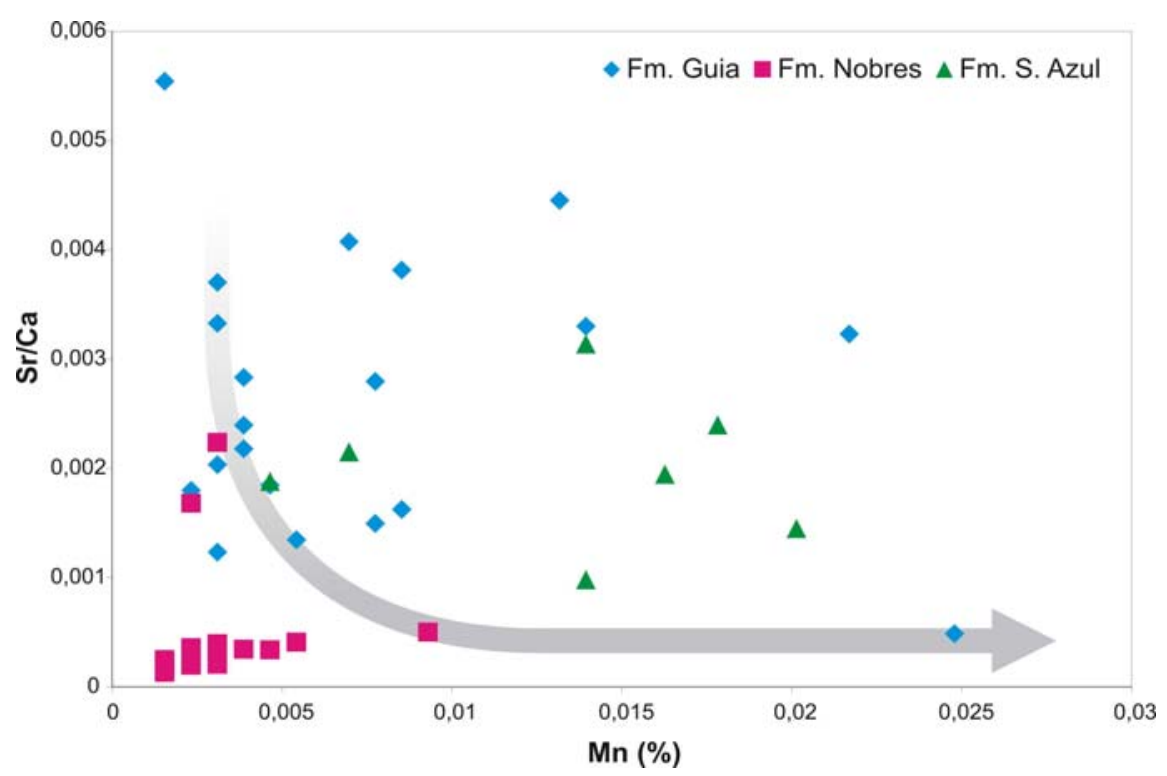

Figura 38. Relação entre $\mathrm{Sr} / \mathrm{Ca}$ e $\mathrm{Mn}$ para os carbonatos estudados. A seta indica a direção de alteração durante o aumento da interação com fluidos não marinhos (água doce, meteórica ou mistura de ambas, ou salmouras evaporíticas). 
Conforme proposto por Kah (2000), durante o processo diagenético, se houver interação do sedimento com fluídos isotopicamente mais leves, como água doce, meteórica ou mistura destas, pode ocorrer a diminuição dos valores de $\delta^{18} \mathrm{O}$ e aumento no teor de $\mathrm{Mn}$ nos carbonatos (direção A, Figura 39). O inverso (aumento dos valores de $\delta^{18} \mathrm{O}$ ) ocorre quando a diagênese acontece mediante a interação com fluídos isotopicamente mais pesados, como salmouras evaporíticas e águas intersticiais ascendentes (direção B, Figura 39).

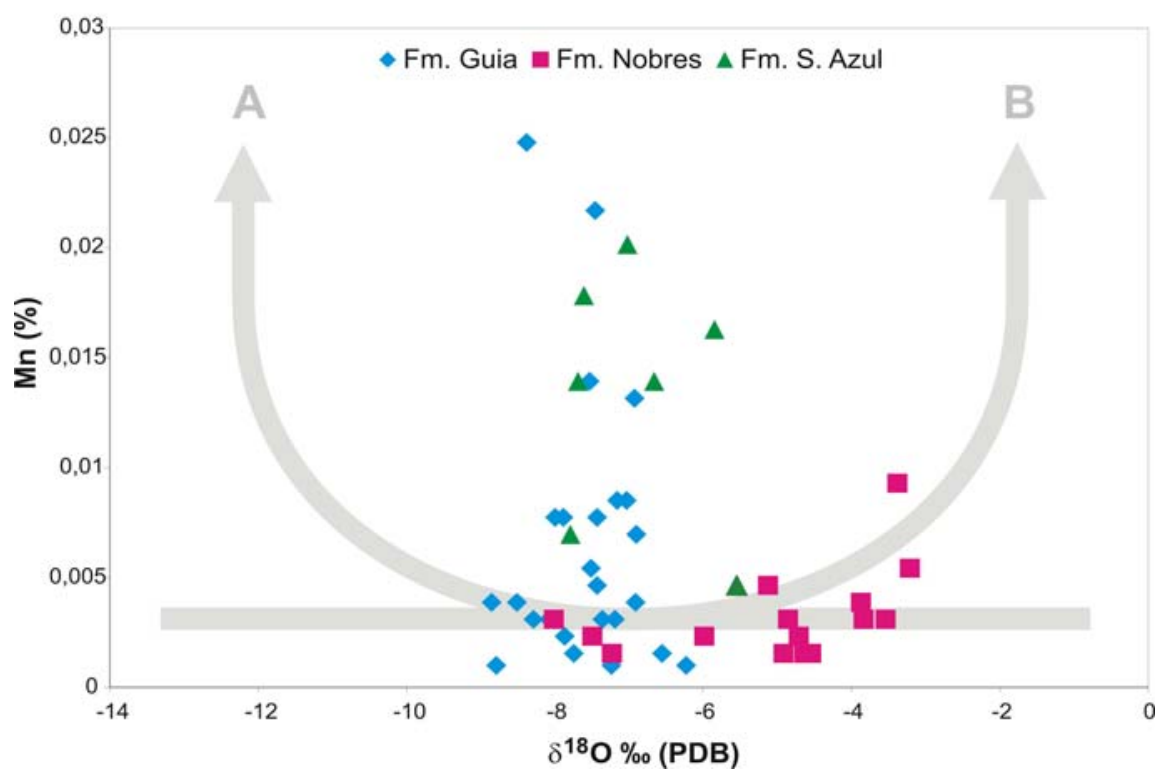

Figura 39. Relação entre os teores de $\mathrm{Mn}$ e valores de $\delta^{180}$ dos carbonatos estudados, onde duas tendências de alteração podem ser observadas. A direção (A) indica o aumento da interação com fluídos isotopicamente mais leves (água doce, meteórica ou mistura de ambas), enquanto que a direção (B) indica o aumento da interação com fluídos isotopicamente mais pesados (salmoura evaporítica ou água intersticial).

Nos carbonatos estudados, a maioria das amostras não segue nenhuma das duas direções de alteração, a não ser algumas amostras da Formação Nobres que possuem uma leve tendência de interação com fluídos isotopicamente mais pesados (Figura 39). Observam-se tendências distintas entre os calcários pós-glaciais das formações Guia e Serra Azul e os dolomitos interglaciais da Formação Nobres. Para os calcários, observa-se uma direção intermediária com enriquecimento de Mn, principalmente da Formação Serra Azul, mas com valores de $\delta^{18} \mathrm{O}$ bem próximos da composição da água do mar aceita para o Neoproterozóico (Kaufman \& Knoll, 1995). Isso indica a presença de minerais ou de fluídos ricos em $\mathrm{Mn}$, que não alteraram significantemente as razões isotópicas de $\mathrm{O}$ originais da água do mar. Já os dolomitos da Formação Nobres mostram leve tendência de interação com fluídos isotopicamente mais 
pesados, mas com pouco Mn. Isso indica que a dolomitização pode ter se dado pela interação do carbonato com água intersticial ascendente, aplicável apenas para os dolomitos secundários. Já os dolomitos primários, intercalados aos dolomitos bioconstruídos que ocorrem no topo da formação Nobres, podem ter se depositado em ambiente temporariamnte restrito, como pequenas salmouras locais, derivadas da evaporação da água do mar retida durante descida do nível relativo do mar.

\subsection{QUIMIOESTRATIGRAFIA ISOTÓPICA}

As rochas estudadas foram depositadas durante um período em que as condições ambientais diferiam muito daquelas reinantes no Fanerozóico. Além disso, estas rochas carecem de uma idade absoluta bem estabelecida ou mesmo de fósseis, induzindo as pesquisas a incluírem o uso das mais diversas ferramentas que possibilitem o estudo paleoambiental e geocronológico. Desta forma, os isótopos de $\mathrm{C}, \mathrm{O}$ e $\mathrm{Sr}$, associados à sedimentologia, são bons instrumentos estratigráficos e permitem estimar uma idade relativa de carbonatos com base nas curvas de variação temporal global de ${ }^{87} \mathrm{Sr} /{ }^{86} \mathrm{Sr}$ e $\delta^{13} \mathrm{C}$, como aquelas propostas por Halverson et al. (2005) e Melezhik et al. (2001), entre outras (ver Figuras 9 e 10, Capítulo 2). Estas curvas também mostram importantes eventos geológicos na história da Terra, como as glaciações globais, demonstradas por bruscas variações nos valores de $\delta^{13} \mathrm{C}$ (incursões negativas para excursões positivas) registradas nos carbonatos.

A curva da variação isotópica de $\delta^{13} \mathrm{C}$ obtida para a sucessão carbonática estudada mostra que a mesma pode ser dividida em oito intervalos quimioestratigráficos distintos (Figura 40A, Tabela 6): (i) o intervalo I corresponde aos primeiros $100 \mathrm{~m}$ da seqüência, abrangendo a base da Formação Guia com valores de $\delta^{13} \mathrm{C}$ negativos de - 0,76 \% a - 0,08 \%o; (ii) o intervalo II, de 150 a $340 \mathrm{~m}$, corresponde ao topo da Formação Guia, com valores de - 1,70 a 0,03%o; (iii) o intervalo III, de 430 a 800 m, corresponde à porção mais basal da Formação Nobres, com valores de $\delta^{13} \mathrm{C}$ de $-1,34$ a - 0,47 \%; (iv) o intervalo IV, de 900 a $1070 \mathrm{~m}$, corresponde à porção mediana da Formação Nobres, com valores $\delta^{13} \mathrm{C}$ positivos próximos a zero $(0,15$ a $0,09 \%$ \%); (v) o intervalo V, de 1200 a 1300 m, da porção de topo da Formação Nobres, apresenta tendência de valores fortemente positivos a próximos de zero (3,97 a 0,43\%o); (vi) o intervalo VI, de 1300 a $1370 \mathrm{~m}$ do topo da Formação Nobres, apresenta valores com tendência positiva, de 0,57 a 2,15 \%; (vii) o intervalo VII corresponde ao topo da Formação Serra Azul, de 80 a 84 m da seção 8, com valores de $\delta^{13} \mathrm{C}$ em tendência negativa, de-7,47 a - 4,92; (viii) o intervalo VIII corresponde 


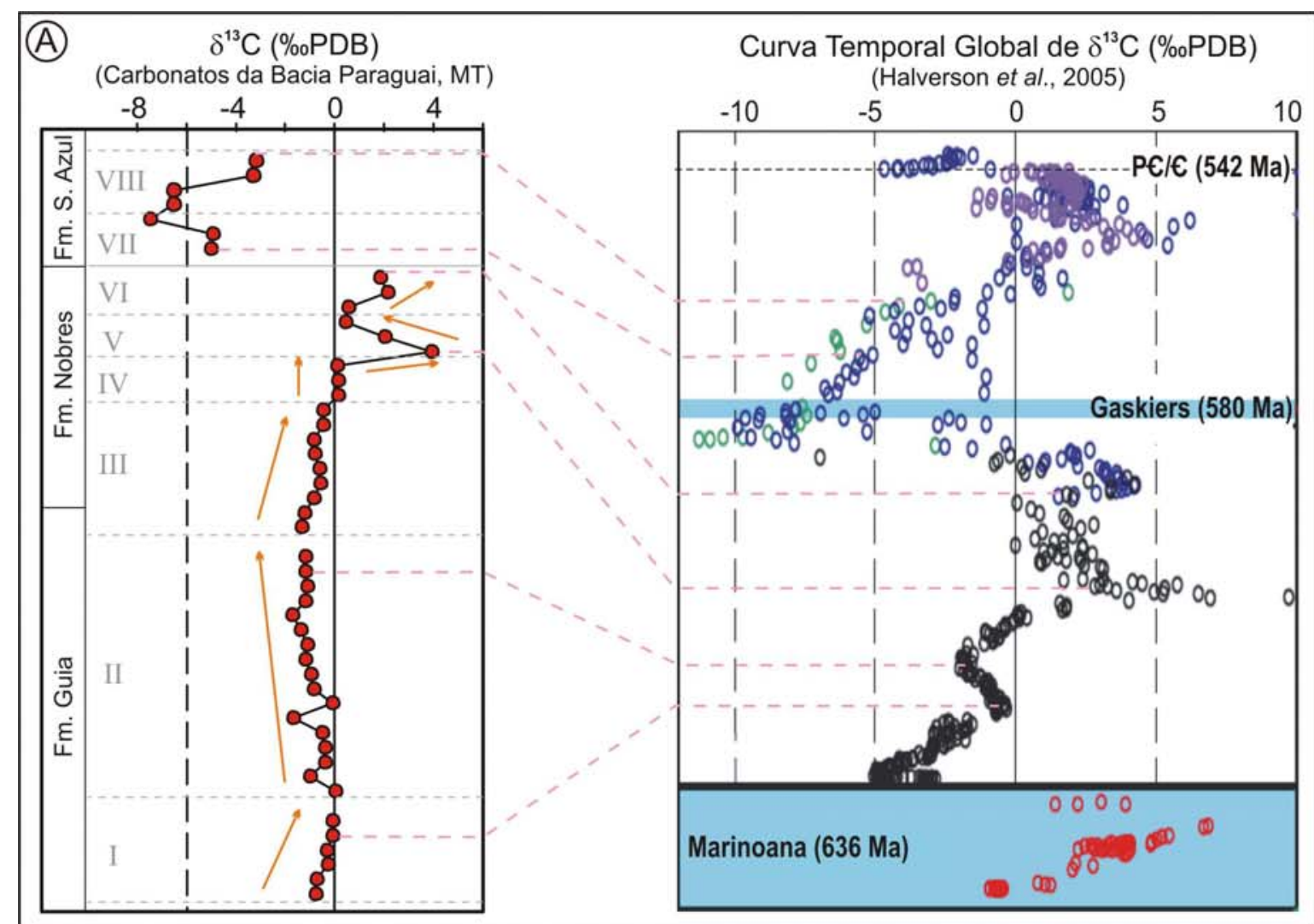

(B)

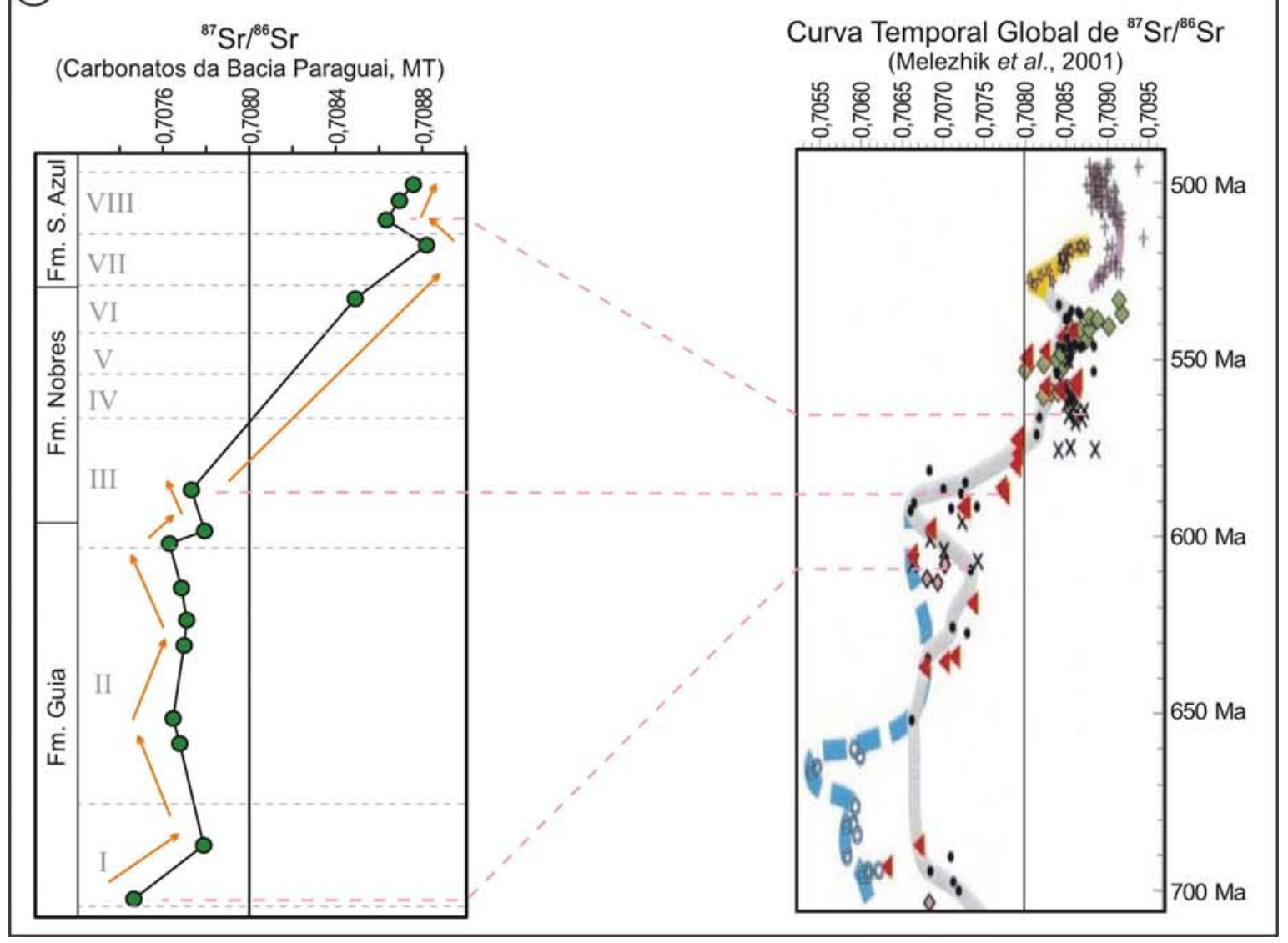

Figura 40. Correlação do padrão de curva isotópica adquirido para os carbonatos da sucessão estudada (sem escala) com as curvas globais de $\delta^{13} \mathrm{C}$ em (A) e ${ }^{87} \mathrm{Sr} /{ }^{86} \mathrm{Sr}$ em (B), em escala temporal. Os intervalos quimioestratigráficos estão notados em números romanos. 
aos calcários restantes para o topo da Formação Serra Azul, de 85 a 92 m da seção 8, com valores em tendência negativa de $-6,53 \mathrm{a}-3,21 \%$.

Uma avaliação cuidadosa destes intervalos quimioestratigráficos, somados aos conhecimentos sedimentológicos obtidos para as sucessões carbonáticas correspondentes, propiciam uma melhor interpretação a respeito do ambiente deposicional destas rochas. Assim, o intervalo I, base da Formação Guia, marca o início da transgressão marinha pós-glacial, como discutido no item 6.1, o que parece ter se dado sob condições climáticas ainda de baixa temperatura e tímido aumento da bioatividade, conforme os valores negativos de $\delta^{13} \mathrm{C}$ de $-0,76$ a $-0,08 \%$ (Figura 40A). As razões ${ }^{87} \mathrm{Sr} /{ }^{86} \mathrm{Sr}$ mostram um rápido aumento na base (de 0,7075 para 0,7078), possivelmente relacionado às altas taxas de intemperismo devidas à deglaciação Puga (Figura 40B). Os valores e razões isotópicas apresentados são semelhantes àqueles obtidos para os calcários sobre os dolomitos de capa da Glaciação Marinoana (Figura 40A). Nogueira et al. (2003b) e Alvarenga et al. (2004) já haviam associado a Formação Puga à Glaciação Marinoana com base nas incursões de $\delta^{13} \mathrm{C}$ obtidas para o dolomito de capa de Mirassol d'Oeste.

O intervalo II coincide com a inundação da plataforma carbonática (item 6.1), cujos valores de $\delta^{13} \mathrm{C}$ (de 0,03 para - 1,70\%) mostram leve redução da bioatividade para o topo (Figura 40A). Esta diminuição da bioatividade pode estar relacionada à espessa lâmina d'água que reduziria a chegada de luz e produziria condições subanóxicas a anóxicas, conforme a possível presença de bactérias redutoras nos níveis mais ricos em matéria orgânica (Figuras 28E e 28F, Capítulo 5), também encontradas por Elie et al. (submetido) na região cratônica, através de estudo com biomarcadores. Observam-se pequenas oscilações nas razões ${ }^{87} \mathrm{Sr} /{ }^{86} \mathrm{Sr}$ (Figura 40B) em torno de 0,7077, que podem refletir variações no nível do mar (Banner, 2004), conforme a presença da intercalação de espessas camadas de calcário rítmico e calcário rico em matéria orgânica (descritos no item 5.1.2). Os padrões isotópicos obtidos neste intervalo também se assemelham àqueles globais (Figuras 40A e 40B) estabelecidos para carbonatos pós Glaciação Marinoana.

No intervalo III ocorre um aumento gradativo nos valores de $\delta^{13} \mathrm{C}(\mathrm{de}-1,34 \mathrm{a}-0,47 \%$ ), ao mesmo tempo em que inicia-se uma regressão marinha. Este aumento evidencia um acréscimo da bioatividade (Figura 40A) conforme a espessura da lâmina d'água era diminuída. As razões ${ }^{87} \mathrm{Sr} /{ }^{86} \mathrm{Sr}$ da porção mais basal deste intervalo mantêm o padrão oscilatório do intervalo anterior, enquanto que o restante do intervalo não dispõe de análises isotópicas de $\mathrm{Sr}$ (Figura 40B). Os resultados isotópicos deste intervalo somados aos dos intervalos anteriores 
mostram uma perfeita correlação com o padrão global pós-marinoano, como mostra a comparação feita na Figura 40A.

Os valores de $\delta^{13} \mathrm{C}$ obtidos para o intervalo IV $(\sim 0,12 \%)$ mostram uma possível estabilização na bioatividade (Figura 40A), que pode refletir condições ambientais submarinhas de luminosidade e temperatura estáveis durante um certo tempo, ou a percolação de fluído dolomitizante por um espesso pacote carbonático, conforme a presença de dolomito cristalino (descrito no item 5.2). Este intervalo não dispõe de dados isotópicos de $\mathrm{Sr}$.

$\mathrm{O}$ intervalo $\mathrm{V}$ mostra intensa atividade biológica através dos valores de $\delta^{13} \mathrm{C}$ fortemente positivos (Figura 40A), notando-se uma tendência negativa para o topo (de 3,97 a 0,43 \%o), ou seja, uma redução considerável da bioatividade. Os menores valores de $\delta^{13} \mathrm{C}$ coincidem com o aparecimento de turbiditos, revelando a influência de climas tempestuosos ou mudanças geotectônicas. Isso traria um maior aporte de terrígenos por correntes de turbidez para dentro da bacia, o que tornaria a água turva, dificultando a passagem de luz através da lâmina d'água e, assim, dificultando o desenvolvimento da biota existente. Este intervalo também não dispõe de razões ${ }^{87} \mathrm{Sr} /{ }^{86} \mathrm{Sr}$. Estes altos valores de $\delta^{13} \mathrm{C}$ coincidem com a primeira excursão fortemente positiva pós-Glaciação Marinoana, que varia de 3 a 10\%, conforme apresentado na Figura 40A.

Uma nova ascensão dos valores de $\delta^{13} \mathrm{C}$ (de 0,57 a 2,15 \%o) para o intervalo VI mostra que a bioatividade volta a aumentar (Figura 40A). Isto coincide com a deposição de carbonatos típicos de água rasa, com evidência de exposição, e com o aumento da presença de bioconstruções oncolíticas, peloidais e estromatolíticas em direção ao topo (discutido no item 6.1). Estes valores de $\delta^{13} \mathrm{C}$ se assemelham ao padrão global que apresenta uma segunda excursão positiva, menos intensa que a primeira, conforme a Figura $40 \mathrm{~A}$. A razão ${ }^{87} \mathrm{Sr} /{ }^{86} \mathrm{Sr}$ adquirida para o topo deste intervalo $(0,7085)$ mostra considerável aumento em relação àquelas obtidas para as porções mais basais da Formação Nobres (Figura 40B). Esta razão mais alta revela um maior intemperismo de rochas mais antigas, que pode ter decorrido de elevações orogênicas causadas pelo Ciclo Brasiliano-Pan Africano ou a um considerável rebaixamento do nível relativo do mar, que aumentaria a erosão de porções mais internas dos crátons.

Entre os intervalos quimioestratigráficos VI e VII existe um espesso pacote de diamictitos e laminitos da Formação Serra Azul, que marcam um novo evento glacial e de deglaciação (discutido no item 6.1). Num contexto pós-glacial, encontra-se o intervalo VII, que apresenta valores de $\delta^{13} \mathrm{C}$ fortemente negativos, chegando a - 7,47\% (Figura 40A), evidenciando um calcário de capa ou calcários depositados pouco depois da glaciação, com valores 
semelhantes aos obtidos para a segunda e menos intensa incursão negativa dos carbonatos pós Glaciação Gaskiers (Figura 40A). As razões ${ }^{87} \mathrm{Sr} /{ }^{86} \mathrm{Sr}$ obtidas para este intervalo mostram-se bem mais radiogênicas que as dos intervalos anteriores (Figura 40B), evidenciando a erosão de uma quantidade ainda maior de materiais rochosos antigos, podendo ser atribuído como o resultado da Orogenia Brasiliana-Pan Africana, que teria construído uma configuração paleogeográfica de relevos elevados, facilitando o intemperismo de um número maior de rochas antigas exumadas.

O intervalo VIII mostra um aumento dos valores de $\delta^{13} \mathrm{C}$ (Figura 40A), que pode estar relacionado a um possível recomeço da bioatividade. As razões ${ }^{87} \mathrm{Sr} /{ }^{86} \mathrm{Sr}$ mostram-se não muito diferentes daquelas obtidas para o intervalo VII e a tendência crescente geral da sucessão formada por estes valores, desde o topo do intervalo VI (Figura 40B), certamente são o reflexo da evolução tectônica progressiva do Ciclo Brasiliano, soerguendo as faixas neoproterozóicas ao redor do mundo.

Conforme comparados os intervalos quimioestratigráficos acima às curvas globais de $\delta^{13} \mathrm{C}$ e ${ }^{87} \mathrm{Sr} /{ }^{86} \mathrm{Sr}$ através do tempo, observa-se uma perfeita correlação da sucessão carbonática estudada com a curva de $\delta^{13} \mathrm{C}$ proposta por Halverson et al. (2005), no intervalo compreendido a partir da Glaciação Marinoana até a deglaciação Gaskiers (Figura 40A), e uma correlação razoável com a curva de ${ }^{87} \mathrm{Sr} /{ }^{86} \mathrm{Sr}$ apresentada por Melezhik et al. (2001), entre 630 e $565 \mathrm{Ma}$ (Figura 40B).

\subsubsection{Correlação com outras seqüências da Faixa Paraguai}

A correlação isotópica de C e Sr entre a sucessão carbonática estudada e outras sucessões da Faixa Paraguai em Mato Grosso, existentes na literatura, é dificultada por vários possíveis motivos, dentre eles (i) o fato de existirem poucos dados isotópicos disponíveis, com intervalos hectométricos, importantes na correlação, (ii) a existência de seções compostas (empilhamento de seções realizadas em áreas distintas na plataforma), não contínuas, que podem gerar repetição ou lacunas temporais, e (iii) a utilização de diferentes procedimentos químicos para análise isotópica de $\mathrm{Sr}$, envolvendo dissolução total ou lixiviação das amostras, que pode gerar razões isotópicas distintas para uma mesma amostra.

Em vista destas dificuldades, a correlação ora proposta para os carbonatos da Faixa Paraguai é tentativa e mostra a necessidade de um maior detalhamento quimioestratigráfico das sucessões apresentadas. Para a porção norte da Faixa Paraguai (Mato Grosso), a curva de $\delta^{13} \mathrm{C}$ obtida para o Grupo Araras neste trabalho (Figura 41A) não inclui dados isotópicos da porção 
mais basal, não encontrada na área de estudo, mas que na região cratônica apresenta valores fortemente negativos identificados Nogueira (2003) e Alvarenga et al. (2004), observados nas figuras 41B (base da seção) e 41C, caracterizando um dolomito de capa. Também na base da sucessão plataformal profunda, Alvarenga et al. (2004) observaram valores fortemente negativos (Figura 41E). As razões ${ }^{87} \mathrm{Sr} /{ }^{86} \mathrm{Sr}$ obtidas neste trabalho para a base da seção estudada (Figura 41A) se assemelham àquelas obtidas igualmente para a base das seções de Nogueira (2003) e Alvarenga et al. (2004), nas Figuras 41B e 41D, respectivamente, com pequenas variações em torno de 0,7075 , razão típica dos carbonatos pós-marinoanos.

Os primeiros $600 \mathrm{~m}$ da sucessão carbonática estudada (Figura 41A) parece apresentar uma boa correlação com o intervalo compreendido entre 350 e 630 m da sucessão estudada por Nogueira (2003) (Figura 41B), embora haja uma lacuna considerável na curva isotópica da base desta seção que não permite correlação. Quando a seção estudada (Figura 41A) é comparada à seção de plataforma profunda de Alvarenga et al. (2004) (Figura 41E), observa-se uma padrão geral bastante semelhante entre ambas, com variações de $\delta^{13} \mathrm{C}$ negativas inferiores a $-2 \%$ ao longo da sucessão, culminando com uma anomalia positiva de 4 \%. Quando se compara a seção estudada (Figura 41A) com a seção plataformal obtida por Alvarenga et al. (2004), observa-se uma relativa similaridade entre as porções mais basal, com ca. - 2 \%o, e de topo, com excurção positiva (Figura 41D). O intervalo intermediário desta seção ( 2\%o) apresenta-se bastante distinto do obtido neste trabalho $(\sim-1 \%)$, ainda sem explicação, apesar de Alvarenga et al. (2004) ter feito uma tentativa de correlação deste intervalo com a Formação Tamengo, em Mato Grosso do Sul, que neste trabalho recebe uma denotação diferente, como será discutido adiante. Os dados de ${ }^{87} \mathrm{Sr} /{ }^{86} \mathrm{Sr}$ obtidos para as diversas seções apresentadas, com exceção da porção basal das Figuras 41A, 41B e 41D, diferem muito entre si. As altas razões ${ }^{87} \mathrm{Sr} /{ }^{86} \mathrm{Sr}$ de até 0,7085 (Alvarenga et al., 2004) e 0,711 (Trindade et al., 2003) obtidas para a seqüência cratônica da região de Mirassol do Oeste, poderiam ser atribuídas aos carbonatos de capa da glaciação Gaskiers, não fosse uma idade $\mathrm{Pb} / \mathrm{Pb}$ de $627 \pm 32 \mathrm{Ma}$ obtida nestes carbonatos por Babinski et al. (submetido). Faulstich et al. (2005) atribuem as altas razões isotópicas de $\mathrm{Sr}$ e o enriquecimento em Fe e Mn observados nos carbonatos de capa da região de Mirassol d' Oeste, à percolação de fluídos mineralizantes que formaram as ocorrências epigenéticas de esfalerita, galena e pirita, hospedadas nestes carbonatos. No entanto, Font (2005) defende que a maior parte do teor de Mn encontrado nestes carbonatos seja primário e típico de carbonatos de capa. 

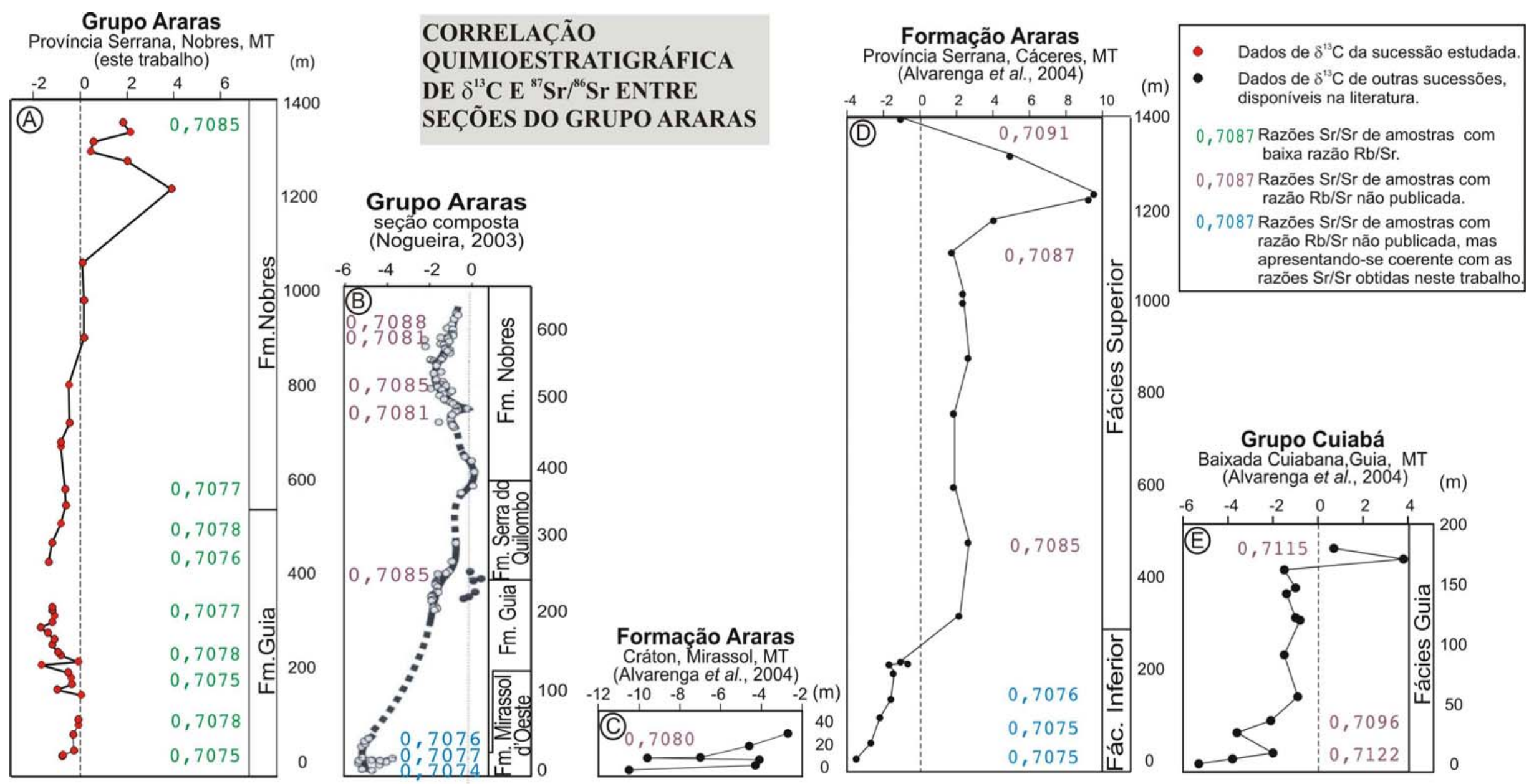

Figura 41. Correlação entre o padrões isotópicos de $\delta^{13} \mathrm{Ce}{ }^{87} \mathrm{Sr} /{ }^{86} \mathrm{Sr}$ obtidos em diversas sucessões carbonáticas da Faixa Paraguai em Mato Grosso. 
Quando os dados obtidos neste trabalho são comparados aos obtidos por Boggiani (1998) e Boggiani et al. (2003) nos carbonatos do Grupo Corumbá (Faixa Paraguai em Mato Grosso do $\mathrm{Sul}$ ), podem-se observar razões ${ }^{87} \mathrm{Sr} /{ }^{86} \mathrm{Sr}$ radiogênicas acima de 0,7085 , semelhantes às obtidas para os carbonatos da Formação Serra Azul. Comparando-se os padrões da curva de $\delta^{13} \mathrm{C}$ para ambas as sucessões (Figura 42), pode-se sugerir que os carbonatos de capa da Formação Puga (Figura 42A) sejam correlatos dos carbonatos de capa encontrados por outros pesquisadores no Grupo Araras (Figuras 41B e 41C). Os valores de $\delta^{13} \mathrm{C}$ obtidos para a Formação Bocaina (Figura 42A) parecem ser correlatos do intervalo compreendido entre 150 e $250 \mathrm{~m}$ do Grupo Araras (Figura 42B), no entanto os dados disponíveis na literatura são insuficientes para uma boa correlação.

Em se tratando da Formação Tamengo (Figura 42A), esta parece ser correlata dos carbonatos pós-Gaskiers, conforme as razões ${ }^{87} \mathrm{Sr} /{ }^{86} \mathrm{Sr}$ de 0,7086 . Contudo, uma idade bem mais jovem, de ca. de $545 \mathrm{Ma}$, é sugerida pelas (i) razões ${ }^{87} \mathrm{Sr} /{ }^{86} \mathrm{Sr}$ de 0,7092 determinadas na sua porção mais basal, (ii) uma idade $\mathrm{U} / \mathrm{Pb}$ de $545 \pm 6 \mathrm{Ma}$ determinada em cristais de zircão de tufos vulcânicos intercalados nos carbonatos (Boggiani et al., 2005) e (iii) a presença de fósseis Cloudina lucianoi (Zaine, 1991), com idade estabelecida entre 549 e 543 Ma na Namíbia (Grotzinger et al., 1998).

Estes dados demonstram que as sucessões situadas em Mato Grosso e Mato Grosso do Sul possuem histórias geológicas distintas e possivelmente não faziam parte da mesma bacia sedimentar, uma questão já levantada por Boggiani (1998). Pela configuração tectônica atualmente conhecida para este período, é possível conceber que a sucessão composta pelo Grupo Araras e pela Formação Serra Azul constituíam uma plataforma depositada na margem do Cráton Amazônico, enquanto que aquela formada pelo Grupo Corumbá constituía uma plataforma depositada na margem do Bloco Rio Apa. Assumindo-se esta configuração, estes sedimentos foram amalgamados no fim do Ciclo Brasiliano, dando origem à Faixa Paraguai. Uma tendência de interpretação tectono-estratigráfica levou muitos pesquisadores a considerar as sucessões carbonáticas, de ambas as porções norte e sul da Faixa Paraguai, como correlatas e partes de uma mesma bacia marinha. Mas, vale salientar, que a evolução do conhecimento atual apenas possibilitou a identificação de diferenças entre estas duas porções, que necessitam de um estudo ainda mais aprofundado para se confirmar as evidências observadas. 
Formação Serra Azul

Província Serrana, Nobres, MT (este trabalho)

\section{Grupo Corumbá}

seção composta

Bloco Rio Apa, MS

(Boggiani, 1998; Boggiani et al., 2003)

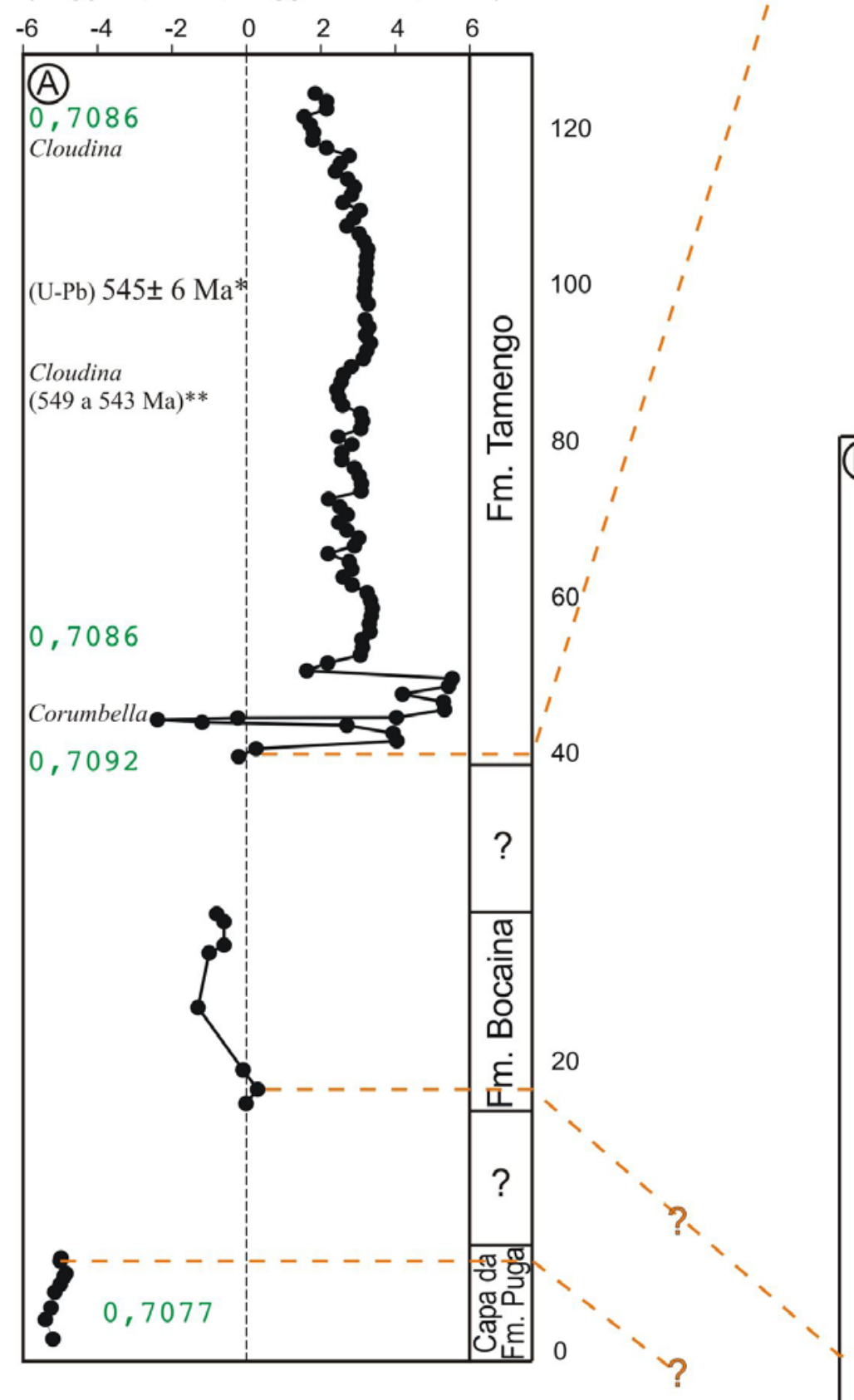

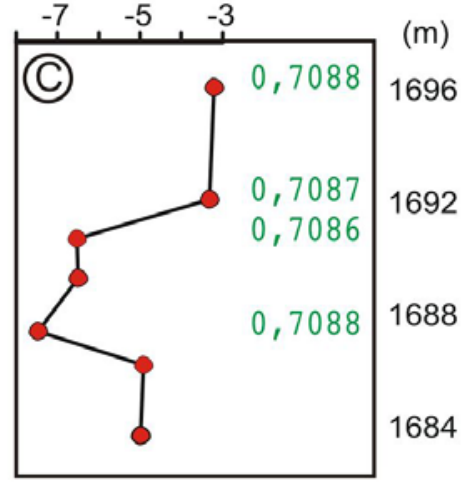

Grupo Araras

Província Serrana, Nobres, MT (este trabalho)

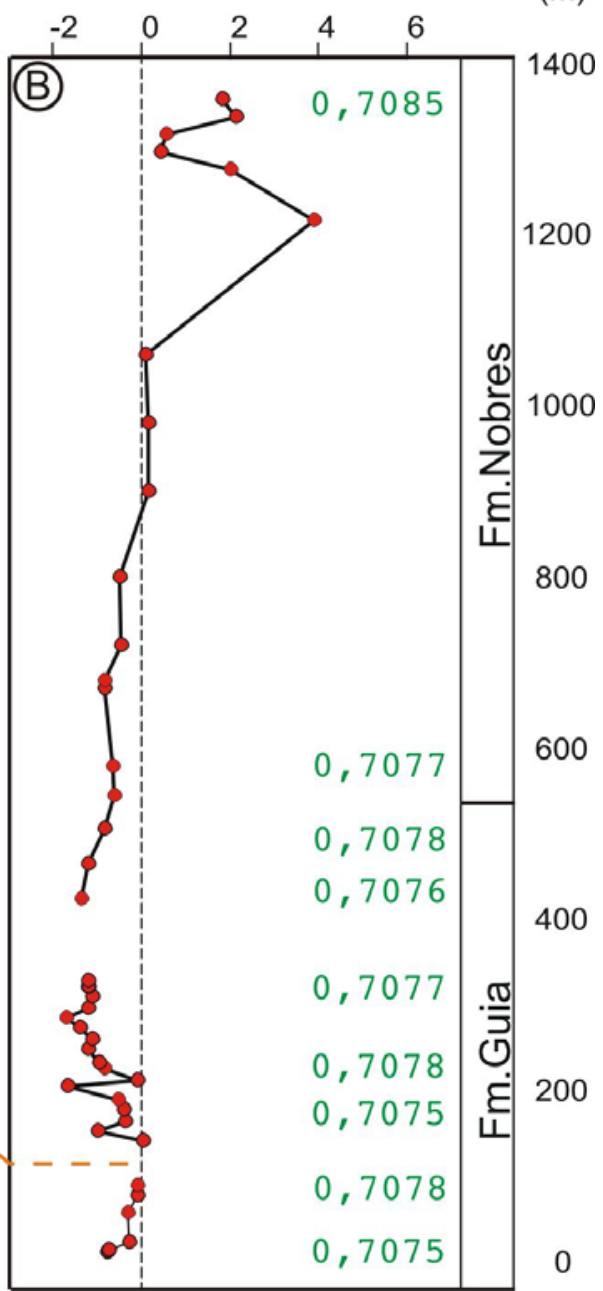

Figura 42. Correlação entre o padrões isotópicos de $\delta^{13} \mathrm{C}$ e ${ }^{87} \mathrm{Sr} /{ }^{86} \mathrm{Sr}$ da Faixa Paraguai, obtidos para os carbonatos da sucessão de Mato Grosso do Sul (A) e da sucessão estudada (B,C) em Mato Grosso. (*) Boggiani et al. (2005); (**) Grotzinger et al. (1998). 


\subsubsection{Correlação global}

A hipótese de Snowball Earth pressupõe a existência de pelo menos três glaciações neoproterozóicas de ocorrência mundial: Sturtiana ( $725 \mathrm{Ma}$ ), Marinoana (635 Ma) e Gaskiers (580 Ma). Os padrões isotópicos de $\mathrm{C}$ adquiridos para as sucessões carbonáticas estudadas, do Grupo Araras e da Formação Serra Azul, mostraram uma boa correlação com os padrões isotópicos globais das glaciações neoproterozóicas mais jovens, Marinoana e Gaskiers, respectivamente (Figura 40A).

Muitos dados geocronológicos vêm sendo gerados para algumas sucessões neoproterozóicas, que possuem ao menos um desses três registros glaciais e/ou carbonatos com incursões de $\delta^{13} \mathrm{C}$ características de deposição pós-glacial, permitindo assim uma maior restrição de idade para estas glaciações globais. Como os carbonatos pós-glaciais do Grupo Araras são tidos como correlatos daqueles pós-marinoanos e os da Formação Serra Azul daqueles pósgaskieranos, far-se-á referência apenas às idades obtidas para as glaciações Marinoana e Gaskiers.

Para a Glaciação Marinoana tem-se obtido recentemente boas idades U-Pb em zircões de: (i) 635,5 \pm 1,2 Ma, de cinzas vulcânicas intercaladas a depósitos glaciais, na Formação Ghaub, Namíbia (Hoffman et al., 2004), (ii) 635,2 \pm 0,6 Ma, de cinzas vulcânicas intercaladas nos dolomitos de capa, da Formação Doushantuo, sul da China (Condon et al., 2005) e (iii) 632,5 \pm 0,5 Ma, de cinzas vulcânicas intercaladas a calcários de topo desta última formação (Condon et al., 2005). Os dolomitos de capa do Grupo Araras foram recentemente datados pelo método Pb$\mathrm{Pb}$ em $627 \pm 32$ Ma (Babinski et al., submetido), confirmando uma idade marinoana e prégaskierana do Grupo Araras.

Para a Glaciação Gaskiers há apenas uma idade U-Pb bem estabelecida de 582,4 \pm 0,4 Ma, através de cinzas vulcânicas intercaladas nos diamictitos da Formação Gaskiers, Newfoundland (dados de Bowring em MacGabhann, submetido). No entanto, esta formação não possui carbonatos pós-glaciais, que poderiam fornecer um padrão isotópico para esta idade, com o qual poderiam ser comparados os padrões isotópicos obtidos em outras seções. Contudo, é certo que existe uma terceira glaciação neoproterozóica, com padrão isotópico característico em carbonatos, que pode ser observado em outras sucessões mundiais, conforme apresentado na Figura 43, aceitas como correlatas da Formação Gaskiers.

Assumindo-se uma contemporaneidade global, é possível correlacionar os resultados isotópicos de $\mathrm{C}$ e $\mathrm{Sr}$ obtidos neste trabalho com aqueles determinados em outras sucessões 
carbonáticas marinhas de mesma idade no mundo (Figura 43). Procurou-se fazer uma correlação com sucessões que possuíssem tanto curvas de $\delta^{13} \mathrm{C}$ quanto razões ${ }^{87} \mathrm{Sr} /{ }^{86} \mathrm{Sr}$ bem determinadas. Assim, comparando-se os padrões isotópicos dos carbonatos plataformais do Grupo Araras, na área estudada, com outras sucessões marinoanas, como os carbonatos também plataformais do Grupo Otavi, na Namíbia (Halverson et al., 2005), nota-se uma excelente correlação entre as curvas de $\delta^{13} \mathrm{C}$ de ambas as sucessões (Figura 43D e 43E), especialmente entre os primeiros 900 $\mathrm{m}$ do Grupo Araras (Figura 43E) e os primeiros $850 \mathrm{~m}$ do Grupo Otavi, salientando que a capa carbonática na sucessão estudada não foi encontrada (Figura 43E). As razões isotópicas de Sr ( 0,7075), na porção basal de ambas as seções, também se apresentam coerentes. A correlação destes dois grupos já havia sido notada por Nogueira et al. (2005), mas apenas entre a primeira metade do Grupo Araras e as duas primeiras formações do Grupo Otavi (Maieberg e Elandshoek) que, com os dados deste trabalho, podem ser estendidos para a Formação Hüttenberg (Figura 43D). Uma boa correlação também ocorre quando os dados isotópicos obtidos no topo da Formação Nobres são comparados com aqueles adquiridos para a Formação Khufai (Figuras 43E e 43B), Grupo Nafun, em Omã (Burns \& Matter, 1993), apresentando o mesmo padrão de curva de $\delta^{13} \mathrm{C}$, com excursões positivas, e razões ${ }^{87} \mathrm{Sr} /{ }^{86} \mathrm{Sr}$ de 0,7084 no topo (Figura 43B), bem próxima da razão 0,7085 obtida no topo da Formação Nobres (Figura 43E).

Os dados isotópicos dos carbonatos da Formação Serra Azul (Figura 43C) podem ser correlacionados aos carbonatos de sucessões gaskieranas de outras bacias, tais como o Grupo Nafun (Figura 43B), em Oman (Burns \& Matter, 1993 e Cozzi et al., 2004), e a Formação Wonoka (Figura 43A), na Austrália (Calver, 2000), que apresentam o padrão de variação e amplitude de $\delta^{13} \mathrm{C}$ semelhantes ao obtido para a Formação Serra Azul, assim como os valores de ${ }^{87} \mathrm{Sr} /{ }^{86} \mathrm{Sr}(0,7087)$, que mostram uma ótima correlação entre os carbonatos destas três sucessões (topo do Grupo Nafun e formações Wonoka e Serra Azul). 


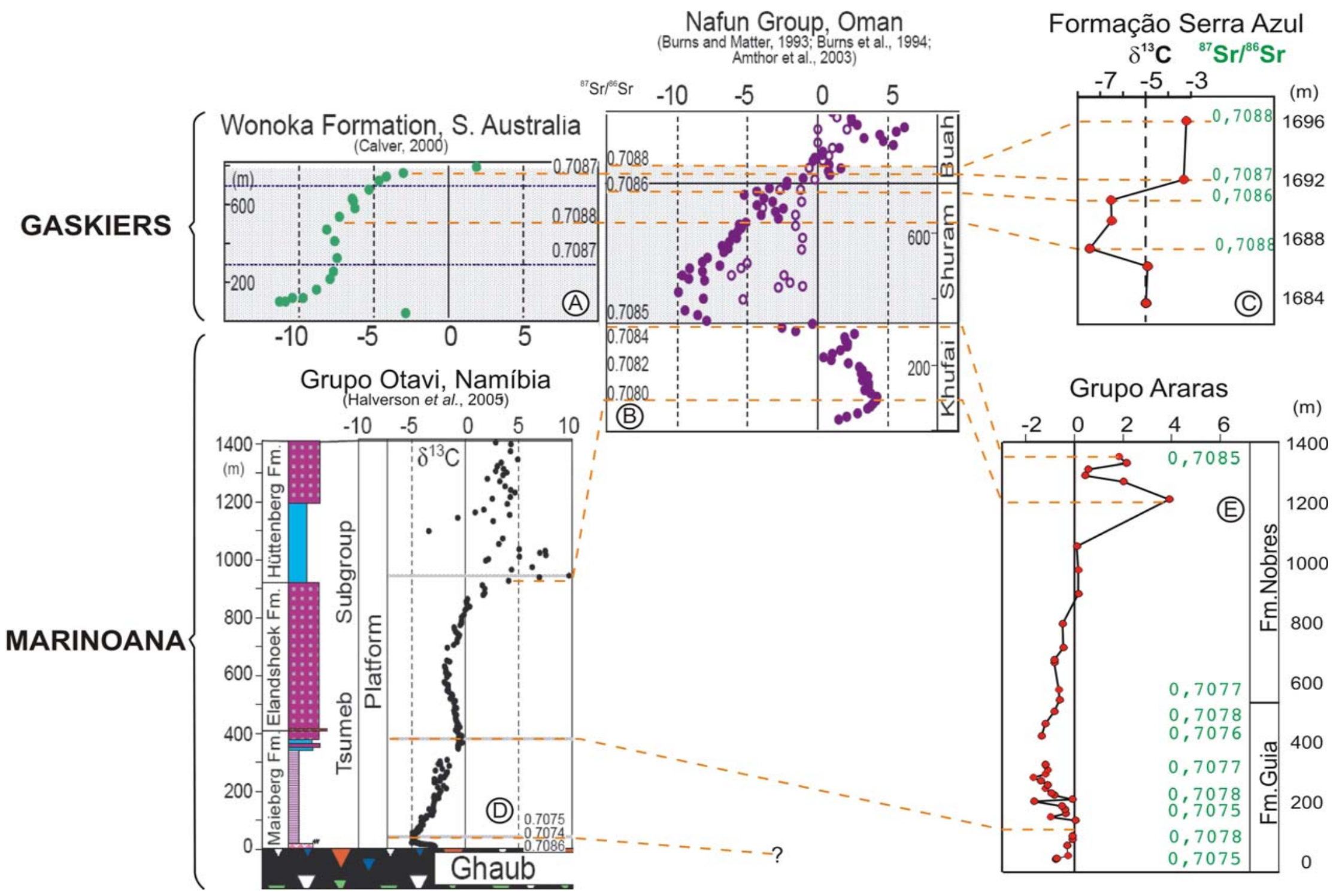

Figura 43. Comparação quimioestratigráfica da sucessão estudada com outras sucessões mundiais, mostrando perfeita correlação entre as curvas de $\delta^{13} \mathrm{C}$ e as razões ${ }^{87} \mathrm{Sr}{ }^{86} \mathrm{Sr}$. 


\subsection{PROVENIÊNCIA DE SEDIMENTOS}

Os sedimentos pelíticos da Formação Serra Azul mostraram idades Sm-Nd TDM variando entre 1,6 a 2,0 Ga e $\varepsilon_{\mathrm{Nd}(\mathrm{t}=0)}$ negativo, oscilando entre -12,86 e -15,42 (ver Tabela 7 e Figura 34, Capítulo 5), o que remete a fontes paleoproterozóicas e mesoproterozóicas constituídas predominantemente por rochas de origem crustal. Estes sedimentos foram depositados na margem sudeste do Cráton Amazônico (Figura 42) durante o Ediacariano, por processos glaciais e de deglaciação que costumam misturar uma ampla variedade de tipos de rocha, com idades variadas, expostas em áreas bastante extensas.

Comparando os resultados obtidos com dados existentes dos terrenos e províncias do Cráton Amazônico, observa-se maior probabilidade de que as rochas-fontes dos sedimentos estudados sejam predominantemente da Província Rio Negro-Juruena, com contribuições das províncias Ventuari-Tapajós e Rondoniana-San Inácio (Figura 44). A província Rio NegroJuruena consta de uma sucessão de arcos magmáticos com intensa ocorrência de granitos e migmatitos, principalmente em sua parte sul, justificando a tendência negativa do $\varepsilon_{\mathrm{Nd}}(\mathrm{t}=0)$ adquirido para a seqüência glacial estudada. As idades da Província Rio Negro-Juruena variam entre 1,8 a 1,55 Ga (Tassinari \& Macambira, 1999), sendo que duas unidades (cristalizadas há 1,59 Ga), o Batólito Santa Cruz e o Gnaisse São Domingos, apresentam idades TDM de 2,05 Ga (Ruiz, 1992). De acordo com estas idades, é provável que os sedimentos analisados sejam derivados da mistura das rochas desta província, com mistura de rochas mais jovens, possivelmente da Província Rondoniana-San Inácio, para a região de Nobres durante a deposição do topo do laminito vermelho da Formação Serra Azul (seção 8, Figura 18, Capítulo 5).

Pode-se observar que durante a fase glacial (diamictitos) há uma contribuição maior de fontes mais jovens, enquanto que os sedimentos depositados durante a deglaciação possuem uma maior contribuição de fontes mais antigas, talvez como resultado da transgressão marinha que atinge porções mais internas do paleocontinente, aumentando também os níveis dos rios. Também é possível notar que há considerável diferença entre as idades TDM da região de Nobres e da região da Serra Azul, sugerindo que diferentes fontes contribuíram para a formação destas rochas. Comparando a fase transgressiva (laminitos vermelhos), nota-se o predomínio de fontes mais antigas na região da Serra Azul (1,8 a 1,9 Ga) em relação à Nobres $(1,6 \mathrm{Ga})$, enquanto que na fase de mar alto (laminito cinza) predominam fontes mais antigas na região de Nobres $(2,0 \mathrm{Ga})$ em relação à Serra Azul $(1,8 \mathrm{Ga})$. 


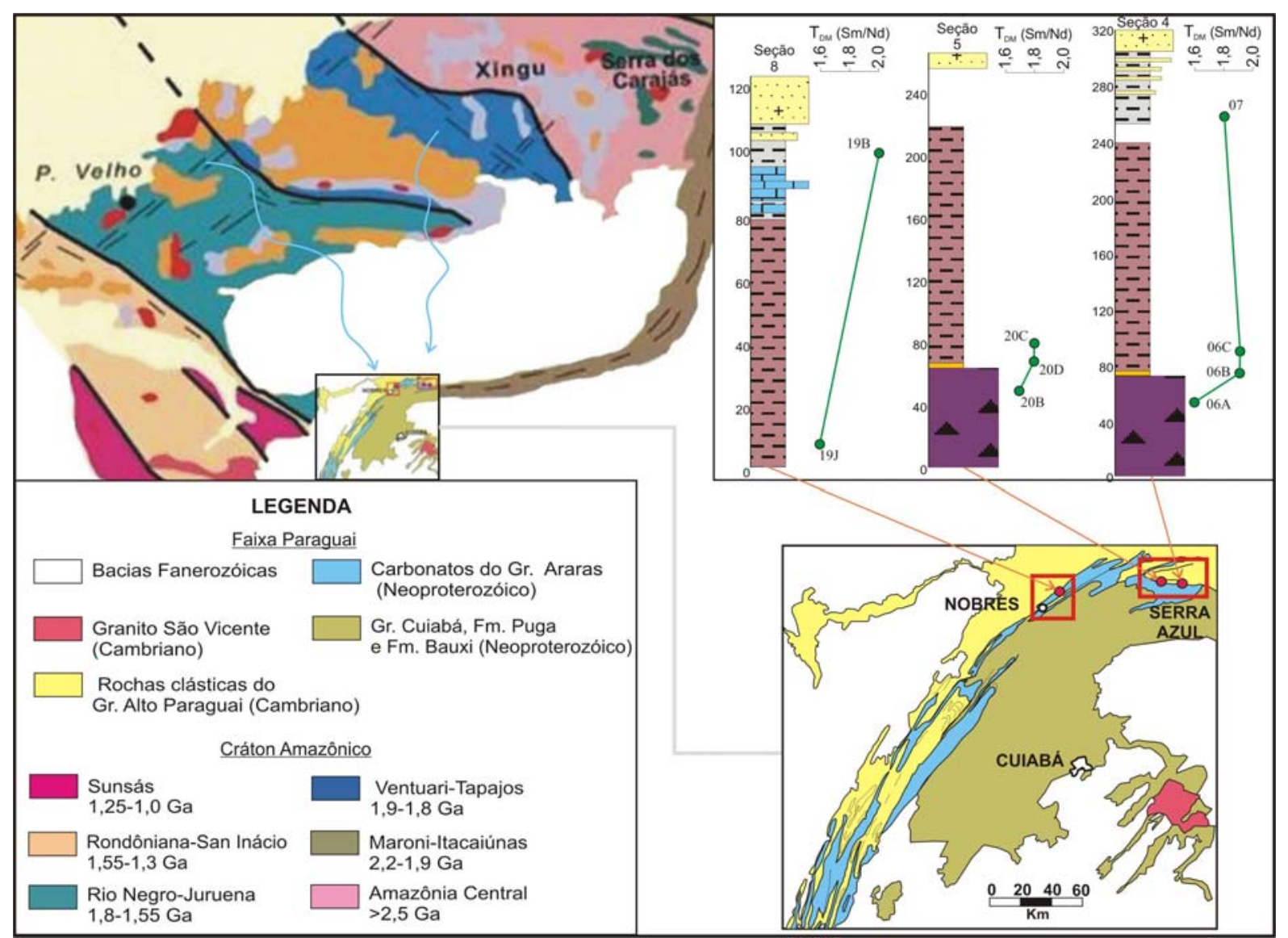

Figura 44. Proveniência dos sedimentos terrígenos da Formação Serra Azul, tendo como principais fontes os terrenos do Cráton Amazônico (Tassinari \& Macambira, 1999) mais próximos às áreas estudadas. 


\section{CAPÍTULO 7 CONCLUSÕES}

As observações geológicas e geoquímicas feitas durante a realização deste trabalho, somadas ao conhecimento atual existente na literatura, permitem tecer algumas considerações sobre os métodos utilizados e as rochas de idade ediacariana encontradas no extremo norte da Faixa Paraguai, no Estado do Mato Grosso, conforme se segue.

A associação de dados isotópicos de $\mathrm{C}, \mathrm{O}$ e $\mathrm{Sr}$ mostrou-se uma excelente ferramenta quimioestratigráfica e de correlação de sucessões carbonáticas marinhas penecontemporâneas. Os valores de $\delta^{13} \mathrm{C}$ não mostraram-se afetados por alterações pós-deposicionais e, por isso, fornecem curvas de variação confiáveis que refletem a composição da água do mar no momento da deposição, visto que o C constitui elemento maior nos carbonatos, sendo necessária grande quantidade de fluídos pós-deposicionais para alterar sua razão isotópica original. Quanto aos isótopos de $\mathrm{O}$, são sensíveis indicadores de alterações pós-deposicionais em rochas precambrianas, mas, neste trabalho, também demonstraram, considerando a maior parte das amostras analisadas, padrões característicos de cada ambiente deposicional, refletindo as condições de oxigenação da água em que foram depositados. A utilização dos isótopos de $\mathrm{Sr}$ deve ser acompanhada de rígido controle de qualidade sobre as amostras analisadas, sendo que sua seleção deve ser feita através de petrografia e litogeoquímica. A preparação da amostra deve ser feita dom o uso de microbrocas diamantadas (microdrilling) e a dissolução realizada através da técnica de lixiviação, devendo o primeiro lixiviado ser descartado (L1). Somente a fração (L2) contendo Sr proveniente da estrutura cristalina do mineral, que reflete a composição isotópica de $\mathrm{Sr}$ da água do mar na época de deposição, deve ser analisada. Assim, se obtidas criteriosamente, as razões isotópicas ${ }^{87} \mathrm{Sr} /{ }^{86} \mathrm{Sr}$ constituem ótima ferramenta de correlação entre bacias marinhas neoproterozóicas.

Os trabalhos de campo evidenciaram uma nova seqüência litoestratigráfica até então desconhecida, a qual é denominada neste trabalho de Formação Serra Azul, depositada sobre os carbonatos do Grupo Araras. Observações acuradas indicaram tratar-se de uma seqüência glacial, mostrando que na história geológica da Faixa Paraguai ocorreram, pelo menos, duas glaciações neoproterozóicas. Estas duas glaciações seriam representadas pela Formação Puga, mais antiga e correlacionada à Glaciação Marinoana (635 Ma), e a Formação Serra Azul, a mais jovem 
correlacionada neste trabalho à Glaciação Gaskiers (582 Ma). Estas correlações foram baseadas na comparação das curvas de $\delta^{13} \mathrm{C} \mathrm{e}{ }^{87} \mathrm{Sr} /{ }^{86} \mathrm{Sr}$ obtidas para a área de estudo com as curvas globais de variação temporal de $\delta^{13} \mathrm{C}$ e ${ }^{87} \mathrm{Sr} /{ }^{86} \mathrm{Sr}$ disponíveis na literatura. Como ainda não existe referência a outra glaciação gaskierana no continente sul-americano, a Formação Serra Azul passa a ser a mais jovem glaciação neoproterozóica encontrada e descrita na América Latina até o momento.

A sucessão sedimentar apresentada neste trabalho mostrou uma alternância de depósitos glaciais (clima muito frio) e depósitos carbonáticos bioconstruídos (clima quente), apontando para condições paleoclimáticas extremas, como fortes oscilações na temperatura superficial e produtividade biológica durante o fim do Neoproterozóico. Esta idéia de instabilidade climática e a coerência com os padrões isotópicos globais, para C e Sr, corroboram a hipótese Snowball Earth, dentro da qual as formações Puga e Serra Azul seriam, como já apresentado, representantes sul-americanas das glaciações globais Marinoana (635 Ma) e Gaskiers (580 Ma), respectivamente.

Quando os dados adquiridos na parte norte da Faixa Paraguai (Grupo Araras e Formação Serra Azul) são comparados com aqueles obtidos, por outros autores, na parte sul da Faixa Paraguai (Grupo Corumbá), observam-se diferenças entre a geologia e os padrões isotópicos obtidos para o Grupo Araras e o Grupo Corumbá. Isso pode indicar que a Faixa Paraguai não constituiu uma única bacia deposicional, mas apenas a amalgamação de, pelo menos, duas bacias marinhas distintas. Assim, a porção norte desta faixa, no Estado de Mato Grosso, constituiria uma bacia deposicional marinha desenvolvida na borda sudeste do Craton Amazônico, enquanto que a sua porção sul representaria uma bacia deposicional desenvolvida na borda leste do Bloco Rio Apa, quando estas massas continentais ainda estavam separadas, antes de sua junção ocorrida na fase final do Ciclo Brasilianõ

De acordo com as curvas isotópicas obtidas neste estudo e aquelas existentes na literatura para as sucessões da Faixa Paraguai, no Mato Grosso, as regiões plataformais da área estudada (Província Serrana em Nobres) e de mar profundo (Baixada Cuiabana) do Grupo Araras são temporalmente correlatas. No entanto, existem diferenças entre as porções medianas das sucessões plataformais (Província Serrana) de Nobres e de Cáceres. A região continental (cratônica em Mirassol d'Oeste) mostra correlação temporal apenas com a porção mais basal das outras regiões (Província Serrana em Cáceres e Baixada Cuiabana). 
Em relação ao sul da Faixa Paraguai, no Mato Grosso do Sul, os dados são insuficientes para uma boa correlação, no entanto são perceptíveis algumas evidências. Os dolomitos vermelhos depositados sobre a Formação Puga, no Morro do Puga, são temporalmente correlatos daqueles depositados sobre o Cráton Amazônico, em Mirassol d'Oeste. Existe a possibilidade dos dolomitos da Formação Bocaina serem correlatos de parte dos carbonatos do Grupo Araras, enquanto que os calcários da Formação Tamengo são mais jovens que os carbonatos da Formação Serra Azul.

O estudo de proveniência dos sedimentos pelíticos da Formação Serra Azul, realizado através de análises isotópicas de $\mathrm{Sm}-\mathrm{Nd}$, demonstrou que tanto as geleiras, quanto as águas de degelo, trouxeram sedimentos heterogêneos para a bacia deposicional, predominantemente de origem crustal, conforme os valores negativos de $\varepsilon_{\mathrm{Nd}}(\mathrm{t}=0)$. Provavelmente estes sedimentos sejam provenientes de várias partes da região sudeste do Cráton Amazônico, com maior contribuição da Província Rio Negro-Juruena, como mostraram as idades Sm-Nd $\mathrm{T}_{\mathrm{DM}}$ de 1,6 a 2,0 Ga. 


\section{REFERÊNCIAS BIBLIOGRÁFICAS}

Agassiz, L., 1840. Etudes sur les glaciers. Privately published, Neufchatel, Switzerland.

Allan, J.R. \& Mattheus, R.K., 1982. Isotope signature with early meteoric diagenesis. Sedimentology 29:797-817.

Almeida, F.F.M., 1964. Geologia do Centro-Oeste Matogrossense. Ministério de Minas e Energia, Departamento Nacional de Produção Mineral, Boletim da Divisão de Geologia Mineral 215, 1-137.

Alvarenga, C.J.S., 1988. Turbiditos e a glaciação do final do Proterozóico Superior no Cinturão Paraguai, Mato Grosso. Revista Brasileira de Geociências 18: 323-327.

Alvarenga, C.J.S., 1990. Phénomenes Sédúnentaires, Structuraux et Circulation de Fluides Développés à la Transition Chane-Craton: Example de la Quote Paraguai d'age Proterozoque Supérieur, Mato Grosso, Brésil. These Docteur, Université d'Aix Marseille HI, France, 177 p.

Alvarenga, C.J.S., Trompette, R., 1992. Glacial influenced turbidite sedimentation in the uppermost Proterozoic and Lower Cambrian of the Paraguay Belt (Mato Grosso, Brazil). Palaeogeography, Palaeoclimatology, Palaeoecology 92: 85-105.

Alvarenga, C.J.S., Santos, R.V., Dantas, E.L., Brod, E.R., Gióia, S.M.C.L., 2003. C, O and Sr isotope in the cap carbonate sequence overlying Sturtian-Rapitan and Varanger-Marinoan Glacial events in Brazil. IV South American Symposium on Isotope Geology, Salvador, Brazil. Short Papers 1:313-316.

Alvarenga, C.J.S., Santos, R.V., Dantas, E.L., 2004. C-O-Sr isotopic stratigraphy of cap carbonates overlying Marinoan-age glacial diamictites in the Paraguay Belt, Brazil. Precambrian Research 131: 1-21.

Alvarenga, C.J.S., Figueiredo, M.F., Babinski, M., Pinho, F.E.C. (submetido). Glacial diamictites of Serra Azul Formation (Ediacaran, Paraguay Belt): evidence of the Gaskiers glacial event in Brazil. Journal of South American Earth Science.

Amthor, J.E., Grotzinger, J.P., Schröder, S., Bowring, S.A., Ramezani, J., Martin, M.W., Matter, A., 2003. Extinction of Cloudina and Namacalathus at the Precambrian-Cambrian boundary in Oman. Geology 31: 431-434.

Arndt, N.T. \& Goldstein, S.L., 1987. Use and abuse of TDM ages. Geology 15:893-895.

Asmerom, Y., Jacobsen, S.B., Knoll, A.H., Butterfield, N.J., Swett, K., 1991. Strontium isotopic variations of Neoproterozoic seawater: Implications for crustal evolution. Geochimica et Cosmochimica Acta 55: 2883-2894.

Babinski, M., Trindade, R.I.F., Alvarenga, J.C., Boggini, P.C., Liu, D., Santos, R.V., (submetido). Geochronological constrains on the neoproterozóic glaciations in Brazil. Snowball Earth Conference, Ascona, Switzerland.

Baker, P.A., Gieskes, J.M., Elderfield, H., 1982. Diagenesis of carbonates in deep-sea sediments: evidence from $\mathrm{Sr} / \mathrm{Ca}$ ratios and interstitial dissolved $\mathrm{Sr}^{2+}$ data. Journal of Sedimentology and Petrology 52:71-82.

Banner, J.L., 2004. Radiogenic isotopes: systematics and applications to Earth surface processes and chemical stratigraphy. Earth-Science Reviews 65:141-194. 
Banner, J.L., Musgrove, M., Asmerom, Y., Edwards, R.L., Hoff, J.A., 1996. High-resolution temporal record of Holocene ground-water chemistry: tracing links between climate and hydrology. Geology 24:1049-1053.

Bertrand-Sarfati, J. \& Moussine-Pouchkine, A., 1983. Platform-to-basin facies evolution: the carbonates of late Proterozoic (Vendian) Gourma (west Africa). Journal of Sedimentary Petrology 53:275-293.

Boggiani, P.C., 1998. Análise estratigráfica da Bacia Corumbá (Neoproterozóico) - Mato Grosso do Sul. Tese de Doutoramento, Instituto de Geociências da Universidade de São Paulo, São Paulo, $181 \mathrm{p}$.

Boggiani, P.C, Babinski, M., Yamamoto, J.K., Fairchild, T., Riccomini, C, Diragitch, A.A., Liu, D., 2005. U-Pb SHRIMP investigation of ash beds in the Corumbá Group (Ediacaran), Paraguai Belt, Brazil. Symposium on Neoproterozoic-Early Paleozoic Events in SWGondwana, IGCP Project 478, Third Meeting, Namibia, p. 13-16.

Boggiani, P.C., Ferreira, V.P., Sial, A.N., Babinski, M., Trindade, R.I.F., Aceñolaza, G., Toselli, A.J., Parada, M.A., 2003a. The cap carbonate of the Puga Hill (Central South America) in the context of the Post-Varanger glaciacion. IV South American Symposium on Isotope Geology, Salvador, Brazil. Short Papers I: 324-327.

Boggiani, P.C., Sial, A.N., Babinski, M., Ferreira, V.P., 2003b. New carbon isotopic data from the Corumbá Group as a contribuition to a composite section for the Neoprotrozóic III in South America. Symposium on Neoproterozoic-Early Paleozoic Events in SW-Gondwana, IGCP Project 478, First Meeting, South Africa, p. 13-16.

Bolles, E.B., 1999. The Ice Finders. Counterpoint, Washington, 257 p.

Brand, U., \& Veizer, J., 1980. Chemical diagenesis of a multicomponent carbonate system-1: Trace elements. Journal of Sedimentary Petrology 50: 1219-1236.

Brasier, M.D., Anderson, M.M., Corfield, R.M., 1992. Oxygen and carbon isotope southeastern Newfoundland and England. Geological Magazine 129:319-332.

Broecker, W.S. \& Peng, T.S., 1982. Tracers in the sea. Eldio Press, New York, 690p.

Budyko, M.I., 1969. The effect of solar radiation variations on the climate of the Earth. Tellus 21:611-619.

Burdett, J.W., Grotzinger, J.P., Arthur, M.A., 1990. Did major changes in the stable isotope composition of Proterozoic seawater occur? Geology 18:227-230.

Burns, S.J. \& Matter, A., 1993. Carbon isotopic record of the latest Proterozoic from Oman. Eclogae Geologicae Helviticae 86: 595-607.

Burns, S.J., Haudenschild, U., Matter, A., 1994. The strontium isotopic composition of carbonates from the late Precambrian (ca. 560-540 Ma) Huqf Group of Oman. Chemical Geology 111: 269-282.

Caldeira, K. \& Kasting, J.F., 1992. Susceptibility of the early Earth to irreversible glaciation caused by carbon dioxide clouds. Nature 359:226-228.

Calver, C.R., 2000. Isotope stratigraphy of the Ediacaran (Neoproterozoic III) of Adelaide Rift Complex, Austrália, and the overprint of water column stratification. Precambrian Research 100: 121-150. 
Condon, D., Zhu, M., Bowring, S., Jin, Y., Wang, W., Yang, A., 2005. From the Marinoan glaciation to the oldest bilaterians: $\mathrm{U}-\mathrm{Pb}$ ages from the Doushantuo Formation, China. Science 308:95-98.

Corfield, R.M., 1994. Paleocene oceans and climate: An isotopic perspective. Earth Science Review 37:225-252.

Cozzi, A., Allen, P.A., Grotzinger, J.P., 2004. Understanding carbonate ramp dynamics using $\delta^{13} \mathrm{C}$ profiles: Examples from the Neoproterozoic Buah Formation of Oman. Terra Nova 16: 62-67.

Denison, R.E., Koepnick, R.B., Burke, W.H., Hetherington, E.A., 1998. Construction of the Cambrian and Ordovician seawater 87Sr/86Sr curve. Chemical Geology 152: 325-340.

DePaolo, D.J., 1981. Neodymium isotopes in the Colorado Front Range and crust-mantle evolution in the Proterozoic. Nature 291:193-196.

Derry, L.A., Keto, L.S., Jacobsen, S.B., 1989. Sr isotopic variations in Upper Proterozoic carbonates from Svalbard and East Greenland. Geochimica et Cosmochimica Acta 53(9):2331-2339.

Derry, L.A., Kaufman, A.J., Jacobsen, S.B., 1992. Sedimentary cycling and environmental change in the Late Proterozoic: evidence from stable and radiogenic isotopes. Geochimica et Cosmochimica Acta 56(3):1317-1329.

Derry, L.A., Brasier, M.D., Corfield, R.M., Rozanov, A.Yu., Zhuravlev, A.Yu., 1994. Sr and C isotopes in Lower Cambrian carbonates from the Siberian craton: a paleoenvironmental record during the Cambrian Explosion. Earth Planetary Science Letter 128: 671-681.

Doherty, P. \& Wegryn, E. 2004. Rings of Saturn. Scientific Explorations and Adventures Home

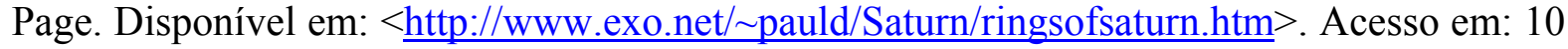
out. 2005.

Dunham, R.J., 1962. Classification of carbonates rocks according to depositional texture. In: Ham, W.E. (ed.). Classification of carbonate rocks. American Association of Petroleum Geologists, p. 108-121 (memoir 1).

Elderfield, H. \& M. J. Greaves. 1982. The rare earth elements in seawater. Nature 296: 214-219.

Elie, M., Nogueira, A.C.R, Trindade, R.I.F, Nédélec, A., Kening, F., (submitted). A red algal bloom in the Neoproterozoic Snowball Earth aftermath. Nature.

Eyles N \& Menzies J., 1983. The Subglacial Landsystem. In: Eyles N. (ed.), Glacial Geology. Oxford, Pergamon Press, p. 19-70.

Eyles, N. \& Januszczak, N., 2004. 'Zipper-rift': a tectonic model for Neoproterozoic glaciations during the breakup of Rodinia after 750 Ma. Earth-Science Reviews 65:1-73.

Fairchild, I.J., Spiro, B., Herrington, P.M., Song, T., 2000. Controls on Sr and C isotope compositions of Neoproterozoic Sr-rich limestones of east Greenland and north China. In: Grotzinger, J.P \& James, N.P (eds.). Carbonate sedimentation and diagenesis in the evolving Precambrian world. Society of Economic Paleontologists and Mineralogists, Special Publication 67:297-314. 
Faulstich, F., Dardenne, M.A., Alvarenga, C.J.S., 2005. Ocorrência de Esfalerita nos carbonatos neoproterozóicos da Formação Araras, Mirassol d'Oeste, Mato Grosso. IX Simpósio de Geologia do Centro-Oeste, Brazil, p. 205-206.

Faure, G., 1986. Principles of Isotope Geology. John Wiley, New York, 589p.

Figueiredo, M.F., Babinski, M., Alvarenga, C.J.S., Pinho, F.E.C., 2004. Diamictites overlying Marinoan-age carbonates of Araras Formation, Paraguay Belt, Brazil: evidence of a new glaciation? Symposium on Neoproterozoic-Early Paleozoic Events in SW-Gondwana, IGCP Project 478, Second Meeting, Brazil, p. 18-19.

Figueiredo, M.F., Babinski, M., Alvarenga, C.J.S., Pinho, F.E.C., 2005a. Nova unidade litoestratigráfica: Formação Serra Azul, Faixa Paraguai, Mato Grosso. IX Simpósio de Geologia do Centro-Oeste, Brazil, p 23-25.

Figueiredo, M.F., Babinski, M., Alvarenga, C.J.S., Pinho, F.E.C., 2005b. Quimioestratigrafia de $\mathrm{C}, \mathrm{O}$ e $\mathrm{Sr}$ dos carbonatos ediacaranos da Faixa Paraguai, Mato Grosso. Mídia digital do X Congresso Brasileiro de Geoquímica e II Simpósio de Geoquímica dos Países do Mercosul, 3 pp.

Font, E.C., 2005. Paleomagnetismo dos carbonatos de capa do Cráton Amazônico (Brasil): implicações para as glaciações do Neoproterozóico. Tese de doutoramento, Instituto de Astronomia, Geofísica e Ciências Atmosféricas da Universidade de São Paulo, São Paulo, $203 \mathrm{p}$.

Ganzer, E. B. \& Figueiredo, M. F., 2004. Mapeamento Geológico e Estudo Geoquímico do Gr. Alto Paraguai, Marzagão-MT. Trabalho de Conclusão de Curso, Geologia, Universidade Federal de Mato Grosso.

Grant, S.W.F., 1992. Carbon isotopic vital effect and organic diagenesis, Lower Cambrian Forteau Formation, northwest Newfoundland: Implications for $\delta^{13} \mathrm{C}$ chemostratigraphy. Geology 20:243-246.

Grotzinger, J.P., 1988. Introduction to Precambrian reefs. In: Geldsetzer, H., James, N.P., Tebbutt, G. (eds.). Reefs - Canadá and adjacent areas. Canadian Society of Petroleum Geologists, p. 9-12 (memoir 13).

Grotzinger, J.P., Watters, W., Knoll, A.H., Smith, O., 1998: Diverse Calcareous Fossils from the Ediacaran-Age Nama Group, Namibia. Geological Society of America 20(7): A-147.

Grotzinger, J.P. \& James, N.P., 2000. Precambrian carbonates: evolution of understanding. Society for Sedimentary Geology, Special Publication 67:3-20.

Halverson, G.P., Maloof, A., Hoffman, P., 2004. The Marinoan Glaciation (Neoproterozoic) in northeast Svalbard. Basin Research 16: 297-324.

Halverson, G.P., Hoffman, P.F., Schrag, D.P., Maloof, A.C., 2005. Toward a Neoproterozoic composite carbon-isotope record. Geological Society of America 117(9): 1181-1207.

Harland, W.B., 1965. Critical Evidence for a Great Infra-Cambrian Glaciation. Geologische Rundschau 54(1):45-61.

Harland, W.B. \& Bidgood, D.E.T., 1959. Palaeomagnetism in some Norwegian Sparagmites and the Late Pre-Cambrian Ice Age. Nature 184:1860-1862. 
Harland, W.B. \& Rudwick, M.J.S., 1965. The Great Infra-Cambrian ice age. Scientific of American 211(2):28-36.

Hennies, W.T., 1966.Geologia do Centro-Norte Mato-Grossense. Tese de Doutoramento, Escola Politécnica, Universidade de São Paulo, 65 p.

Hoffman, P.F., Kaufman, A.J., Halverson, G.P., Schrag, D.P., 1998. A Neoproterozoic Snowball Earth. Science 281:1342-1346.

Hoffman, P.F. \& Schrag, D.P., 1999. The Snowball Earth. Department of Earth and Planetary Sciences, Harvard University. Disponível em: $<$ http://www.eps.harvard.edu/people/faculty/ hoffman/snowball paper.html>. Acesso em: 11 abr. 2005.

Hoffman, P.F. \& Schrag, D.P., 2000. Snowball Earth. Scientific American, January: 68-75.

Hoffman, P.F. \& Schrag, D.P., 2002. The Snowball Earth hypothesis: testing the limits of global change. Terra Nova 14(3):129-155.

Hoffman, K.H., Condon, D., Bowring, S., Crowley, J., 2004. A U-Pb zircon date from the Neoproterozoic Ghaub Formation, Namibia: Constraints on Marinoan glaciation. Geology 32(9):817-820.

Jacobsen, S. \& Kaufman, A., 1999. The Sr, C and O isotopic evolution of the Neoproterozoic seawater. Chemical Geology 161:37-57.

Jones, C.E., Jenkyns, H.C., Coe, A.L., Hesselbo, S.P., 1994. Strontium isotopic variations in Jurassic and Cretaceous seawater. Geochimica et Cosmochimimica Acta 58:3061-3074.

Kah, L.C., 2000. Depositional $\mathrm{d}^{18} \mathrm{O}$ signatures in Proterozoic dolostones: constraints on seawater chemistry and early diagenesis. In: Grotzinger, J.P. \& James, N.P. (eds.), 2000. Carbonate sedimentation and diagenesis in the involving Precambrian World. Society for Sedimentary Geology, Special Publication 67.

Karthur, J.A., 1993. Paleoproterozoic evolution of the carbon isotope ratios of sedimentary carbonates in the Fennoscandian Shield. Bulletin of Geological Survey of Finland 371:1-87.

Kaufman, A.J. \& Knoll, A.H., 1995. Neoproterozoic variations in the C-isotopic composicional of seawater: Stratigrafic and biogeochemical implications. Precambrian Research 73:27-49.

Kaufman, A.J., Knoll, A.H., Awramik, S.M., 1992. Biostratigraphic and chemostratigraphic correlation of Neoproterozoic sedimentary successions: Upper Tindir Group, northwestern Canada, as a test case. Geology 20:181-185.

Kaufman, A.J., Jacobsen, S.B., Knoll, A.H., 1993. The Vendian record of Sr- and C-isotopic variations in seawater: implications for tectonics and paleoclimate. Earth and Planetary Science Letters 120:409-430.

Kaufman, A.J., Knoll, A.H., Narbonne, G.M., 1997. Isotopes, ice ages, and terminal Proterozoic Earth history. National Academy of Sciences Proceedings 94:6600-6605.

Kirschvink, J.L. 1992. Late Proterozoic Low-Latitude Global Glaciation: the Snowball Earth. In: Schopf, J.W., Klein, C. (eds.) 1992: The Proterozoic Biosphere - A Multidisciplinary Study. Cambridge University Press, p 51-52.

Kirschvink, J.L. 2002. Quand Tous les Océans Étaient Gelés. La Recherche 355: 26-30. 
Knoll, A.H. \& Sweet, K., 1990, Carbonate deposition during the later Proterozoic Era: An example from Spitsbergen. American Journal of Science 290:104-132.

Knoll, A.H. \& Walter, M.R., 1992. Latest Proterozoic stratigraphy and Earth history. Nature 356:673-678.

Knoll, A.H., Bambach, R.K., Canfield, D.E., Grotzinger, J.P., 1996. Comparative Earth history and Late Permian mass extinction. Science 273, 452-457.

Kullerud, K., 2005. The Sm-Nd method of dating. Department of Geology, University of

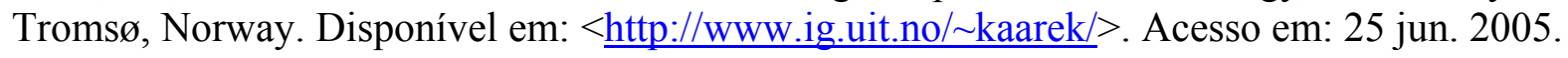

Kuznetsov, A.B., 1998. Evolution of Sr isotopic composition in late Riphean seawater: the Karatau Group carbonates, Southern Urals. Doctoral dissertation, Institute of Precambrian Geology and Geochronology, Russian Academy of Sciences, Saint Petersburg, Russia.

Laskar, J., Joutel, F., Robutel, P., 1993. Stabilization of the Earth obliquity by the Moon. Nature 361:615-617.

MacGabhan, B.A. (submetido). Age Constraints on Precambrian glaciations and the subdivisión of Neoproterozoic time. E-mail list of International Geological Correlation Program 512. Disponível em: <igcp512@,lmtg.obs-mip.fr >.

Mallinson, D. \& Compton, J.S., 1997. Linking phosphogenetic episodes on the southeast U.S. margin to marine $\delta^{13} \mathrm{C}$ and $\delta^{18} \mathrm{O}$ records. Geology 25:103-106.

Marshall, H.G., Walker, J.C.G., Kuhn, W.R. 1988. Long-term climate change and the geochemical cycle of carbon. Journal of Geophysical Research 93:791-801.

Martin, E.E., Macdougall, J.D., 1991. Seawater Sr isotopes at the Cretaceous/Tertiary Boundary. Earth and Planetary Science Letters 104:166-180.

Mattes, B.W. \& Conway Morris, S., 1990. Carbonate/evaporite deposition in the Late Precambrian-Early Cambrian Ara Formation of southern Oman. In: Robertson, A.H, Searle, M.P., Ries, A.C. (eds). The geology and tectonics of the Oman Region. Geological Society of London, Special Publication, p. 617-636.

McArthur, J.M., 1994. Recent trends in strontium isotope stratigraphy. Terra Nova 6:331-358.

McCrea, J.M., 1950. On the Isotopic chemistry of carbonates and paleotemperature scale. Journal of Chemistry and Physics 18: 849-857.

Melezhik, V.A., Gorokhov, I.M., Kuznetsov, A.B., Fallick, A.E., 2001. Chemostratigraphy of Neoproterozoic carbonates: implications for 'blind dating'. Terra Nova 13:1-11.

Möller, N.K. \& Kvingan, K. 1988. The genesis of nodular limestone in the Ordovician and Silurian of the Oslo Region (Norway). Sedimentology 35: 405-420.

Nasa, 2004. Saturn's rings. Jet Propulsion Laboratory, University of Arizona, National Aeronautics and Space Administration. Disponível em: $<\underline{\text { http://solarsystem.jpl.nasa.gov/planets/profile.cfm? }}$ Object $=$ Saturn $\&$ Display $=$ Gallery\&Page $=2>$. Acesso em: 10 out. 2005.

Nogueira, A.C.R., 2003. A plataforma carbonática Araras no sudoeste do Cráton Amazônico, Mato Grosso: Estratigrafia, contexto paleoambiental e correlação com os eventos glaciais do Neoproterozóico. Tese de Doutoramento, Instituto de Geociências da Universidade de São Paulo, 173 p. 
Nogueira, A.C.R., Riccomini, C., Sial, A.N., Moura, C.A.V., Trindade, R.I.F. 2003a. C and Sr isotope variations and paleoceanographic changes as recorded in the Late Neoproterozoic Araras carbonate Plataform, Amazon Craton, Brazil. In: IV South American Symposium on Isotope Geology, Salvador, Brazil, Short Papers 1:380-381.

Nogueira, A.C.R., Riccomini, C., Sial, A.N., Moura, C.A.V., Fairchild, T.R., 2003b. Softsediment deformation at the base of the Neoproterozoic Puga cap carbonate (sowthwestern Amazon craton, Brazil) confirmation of rapid icehouse to greenhouse transition in Snowball Earth. Geology 31(7):613-616.

Petri, S., 1987. Código Brasileiro de Nomenclatura Estratigráfica. Revista Brasileira de Geociências 16: 372-376.

Pinho, F.E.C., Sial, A.N., Figueiredo, M.F., 2003. Contribution to the Neoproterozoic C- and Oisotopic record: carbonate rocks from the Paraguay Belt, Mato Grosso, Brazil. In: IV South American Symposium on Isotope Geology, Salvador, Brazil. Short Papers 1:390-393.

Pursell, B. \& Banner, J., 1997. A refined Middle Triassic seawater $87 \mathrm{Sr} / 86 \mathrm{Sr}$ curve based on petrographic and geochemical criteria. Geological Society of American Annual Meeting, Abstracts with Programs, A-42.

Ruiz A.S., 1992. Contribuição à geologia do distrito de Cachoeirinha, MT. Dissertação de Mestrado Instituto de Geociências da Universidade de São Paulo, São Paulo, 98 p.

Schidlowski, M., Hayes, J.M., Kaplan, I.R., 1983. Isotopic inference of ancient biochemistries: carbon, sulfur, hydrogen and nitrogen. In: Schopf, J.M. (ed.), Earth's Earliest Biosphere, its origin and Evolution. Princeton University Press, p. 149-186.

Sellers, W.D., 1969. A global climatic model based on the energy balance of the Earthatmosphere system. Journal of Applied Meteorology 8:392-400.

Shaw, H.F. \& Wasserburg, G.J., 1985. Sm-Nd in marine carbonates and phosphates: implications for $\mathrm{Nd}$ isotopes in seawater and crustal ages. Geochimica et Cosmochimica Acta 49:503-518.

Sheldon, R.P., 1984. Ice-ring origin of the Earth's atmosphere and hydrosphere and Late Proterozoic-Cambrian phosphogenesis. Geological Survey of India. Special Publication $17: 17-21$.

Singh, U., 1987. Ooids and cements from the late Precambrian of the Flinders Ranges, South Australia. Journal of Sedimentary Petrology 57:117-127.

Sumner, D.Y. \& Grotzinger, J.P., 1993. Numerical modeling of ooid size and the problem of Neoproterozoic giant ooids. Journal of Sedimentary Petrology 63: 974-982.

Sumner, D.Y., Kirschvink, J.L., Runnegar, B.N., 1987. Soft-Sediment Paleomagnetic Field Tests of Late Precambrian Glaciogenic Sediments. EOS, Transactions of the American Geophysical Union 68 (44): 1251.

Swett, K. \& Knoll, A.H., 1989. Marine pisólitos from Upper Proterozoic carbonates of East Greenland and Spitsbergen. Sedimentology 36: 75-93.

Tassinari, C.C.G \& Macambira, M.J.B., 1999. Geochronological provinces of the Amazonian Craton. Episodes 22(3):174-182.

Thunell, R.C., Williams, D.F., Howell, M., 1987. Atlantic-Mediterranean water exchange during the Late Neogene. Paleoceanography 2:661-678. 
Trindade, R.I.F., Font, E., D’Agrela Filho, M.S., Nogueira, A.C.R., Riccomini, C., 2003. Lowlatitude and multiple geomagnetic reversals in the Neoproterozoic Puga cap carbonate, Amazon craton. Terra Nova 15(6): 441-446.

Tucker, M.E., 1983. Diagenesis, geochemistry, and origin of a Precambrian dolomite: the Beck Spring Dolomite of eastern California. Journal of Sedimentary Petrology 53: 1097-1119.

Tucker, M.E., 1986. Formerly aragonitic limestone associated with tilites in the Late Proterozoic Kingston Peak Formation of Death Valley, California. Journal of Sedimentary Petrology 56:818-830.

Vanyo, J.P. \& Awramik, S.M., 1982. Length of day and obliquity of the Ecliptic 850 Ma ago: Preliminary results of a Stromatolite Growth Model. Geophysics Research Letters 9:11241128.

Veizer, J., Holser, W.T., Wiguls, C.K., 1980. Correlation of ${ }^{13} \mathrm{C} /{ }^{12} \mathrm{C}$ and ${ }^{34} \mathrm{~S} /{ }^{32} \mathrm{~S}$ secular variations. Geochimica et Cosmochemica Acta 44:579-587.

Veizer, J., Compston, W., Clauer, N., Schidlowski, M., $1983 .{ }^{87} \mathrm{Sr} /{ }^{86} \mathrm{Sr}$ in Late Proterozoic carbonates: Evidence for a mantle event at 900 Ma ago. Geochimica et Cosmochimica Acta 47: 295-302.

Veizer, J., Ala, D., Azmy, K., Bruckschen, P., Buhl, D., Bruhn, F., Carden, G.A.F., Diener, A., Ebneth, S., Godderis, Y., Jasper, T., Korte, C., Pawellek, F., Podlaha, O.G., Strauss, H., 1999. ${ }^{87} \mathrm{Sr} /{ }^{86} \mathrm{Sr}, \delta^{13} \mathrm{C}$ and $\delta^{18} \mathrm{O}$ evolution of Phanerozoic seawater. Chemical Geology 161: 59-88.

Walker, G., 2004. Snowball Earth: the story of the global catastrophe that spawned life as we know it. Geoscience Canada 31(3):141-143.

Walker, J.C.G., 2001. Strange Weather on Snowball Earth. Earth Systems Processes, Edinburgh, Scotland. Geological Society, London, Program Abstracts, p. 110-111.

Walker, J.C.G., 2003. Snowball Earth. Bloomsbury, 269 pp.

Walter, M.R., Veevers, J.J., Calver, C.R., Gorgan, P., Hill, A.C., 2000. Dating the 840-544 Ma Neoproterozoic interval by isotopes of strontium, carbon, and sulfur in seawater, and some interpretative models. Precambrian Research 100: 371-433.

Wilde, P., Berry, W.B.N., 1984. Destabilization of the oceanic density structure and its significance to marine "extinction" events. Palaeogeography Palaeoclimatology and Palaeoecology 48: 143-162.

Williams, G.E., 1975. Late Precambrian glacial climate and the Earth's obliquity. Geological Magazine 112:441-465.

Williams, G.E., 1993. History of the Earth's Obliquity. Earth Science Reviews 34:1-45.

Williams, G.E., 2000. Geological constraints on the Precambrian history of the Earth's rotation and the Moon's orbit. Reviews of Geophysics 38:37-59.

Worsley, T.R. \& Kidder, D.L. 1991. First-order coupling of paleogeography and CO2, with global surface temperature and its latitudinal contrast. Geology 19:1161-1164.

Zaine, M.F. 1991. Análise dos fósseis de parte da Faixa Paraguai (MS, MT) e seu contexto temporal e paleoambiental. Tese de doutoramento, Programa de Pós-Graduação em Geociências da Universidade de São Paulo. 